\title{
HISTÓRICO, CLASSIFICAÇÃO E ANÁLISE DE CENTROS DE EDUCAÇÃO AMBIENTAL NO BRASIL
}

\author{
FÁbIo Deboni dA SiLVA
}

\begin{abstract}
Dissertação apresentada à Escola Superior de Agricultura "Luiz de Queiroz", Universidade de São Paulo, para obtenção do título de Mestre em Recursos Florestais, com opção em Conservação de Ecossistemas Florestais.
\end{abstract}

PIR A C I C A B A

Estado de São Paulo - Brasil

Agosto - 2004 


\title{
HISTÓRICO, CLASSIFICAÇÃO E ANÁLISE DE CENTROS DE EDUCAÇÃO AMBIENTAL NO BRASIL
}

\section{FÁbio Deboni da SiLVA}

Engenheiro Agrônomo

Orientador: Prof. Dr. DALCIO CARON

\begin{abstract}
Dissertação apresentada à Escola Superior de Agricultura "Luiz de Queiroz", Universidade de São Paulo, para obtenção do título de Mestre em Recursos Florestais, com opção em Conservação de Ecossistemas Florestais.
\end{abstract}

PIR ACICABA

Estado de São Paulo - Brasil

Agosto - 2004 
Dados Internacionais de Catalogação na Publicação (CIP) DIVISÃO DE BIBLIOTECA E DOCUMENTAÇÃO - ESALQ/USP

Silva, Fábio Deboni da

Histórico, classificação e análise de centros de educação ambiental no Brasil / Fábio Deboni da Silva. - - Piracicaba, 2004.

$194 \mathrm{p}$.

Dissertação (mestrado) - - Escola Superior de Agricultura Luiz de Queiroz, 2004.

Bibliografia.

1. Biodiversidade 2. Conservação da natureza 3. Desenvolvimento sustentável 4. Ecologia humana 5. Educação ambiental 6. Gestão ambiental 7. Proteção ambiental

I. Título

CDD 333.707

"Permitida a cópia total ou parcial deste documento, desde que citada a fonte - O autor" 
"A educação tem sentido porque o mundo não é necessariamente isto ou aquilo, porque os seres humanos são tão projetos quanto podem ter projetos para o mundo. A educação tem sentido porque mulheres e homens aprenderam que é aprendendo que se fazem e se refazem, porque mulheres e homens se puderam assumir como seres capazes de saber, de saber que sabem, de saber que não sabem. De saber melhor o que já sabem, de saber o que ainda não sabem. A educação tem sentido porque, para serem, mulheres e homens precisam de estar sendo. Se mulheres e homens simplesmente fossem não haveria porque falar em educação" (Paulo Freire, 2000) 


\section{AGRADECIMENTOS}

A DEUS e à Espiritualidade Amiga pelo continuado acompanhamento e oportunidades de crescimento.

A meus pais Romiro e Maria, pela luta e persistência no objetivo de me dar sempre a oportunidade do estudo, pelos ensinamentos constantes de vida, pela oportunidade de evolução neste planeta.

Ao Gustavo, Flávia, Pedro, a "família mais feliz desse mundo".

À minha companheira Soraia Mello (linda) que sempre me incentivou a levar adiante esse trabalho e a continuada luta pela causa ambientalista.

Ao Marcos por ter me dado a oportunidade de adentrar pelos meandros da EA, pelo apoio e oportunidades constantes de crescimento pessoal e profissional.

Ao Caron pelo banho de realidade, generosidade, confiança, apoio e contribuição ao trabalho. Aos momentos de conversas que me iluminaram e abriram novas perspectivas.

Ao ilustre Brandão pelas sempre animadas, carinhosas e elucidativas contribuições.

A CAPES pela concessão da bolsa sem a qual não seria possível a realização deste trabalho.

Ao Prof. Oriovaldo Queda, pela ajuda na concessão do recurso do PROAP. 
Ao pessoal da OCA: Ana Paula, Rita Helena, Flávia, Catarina, Cláudia, Valéria, Sandra, Alexandre, Amílcar, Alexandra, Maria Cláudia, Mário e todos os que contribuíram com este trabalho.

Ao Vitor pelas valiosas considerações em diversos momentos do processo.

A Sílvia (OKA) pela força nas correspondências, envelopes e questionários e pelos "cookies" virtuais.

Ao pessoal da Espanha: Boli, Pablo Meira, CENEAM, Gutiérrez Pérez, Oscar Cid, pelo apoio.

A todo o pessoal da Conferência Nacional do Meio Ambiente pelos meses quase insanos de trabalho, em especial à Rachel, pessoa maravilhosa com quem tive a feliz oportunidade de conhecer e trabalhar.

A toda equipe da Diretoria de Educação Ambiental do Ministério do Meio Ambiente pelo convívio e por manter aceso o ideário ambientalista, apesar das dificuldades.

A todos companheiros da Rede Brasileira de Educação Ambiental e das redes estaduais e temáticas de EA que deram contribuições, provocaram reflexões, abriram perspectivas, enfim, contribuindo com toda a práxis deste trabalho.

A todos os companheiros dos Centros de Educação Ambiental e da Rede CEAs que colaboraram, direta e indiretamente, não só com este trabalho mas na articulação de um processo de interlocução e de co-construção entre CEAs brasileiros, Maurício Ferreira, Déborah Munhoz, Jacqueline Guerreiro, Guaracy Diniz, dentre muitos outros.

A Cláudia Coelho por sua solidariedade e seriedade na finalização deste trabalho.

A todas as outras pessoas que eu tenha me esquecido e que contribuíram para a idealização e consecução desta caminhada, que apenas se inicia rumo a horizontes mais amplos e indefinidos os meus sinceros agradecimentos. 


\section{SUMÁRIO}

Página

LISTA DE FIGURAS ….................................................................. viii

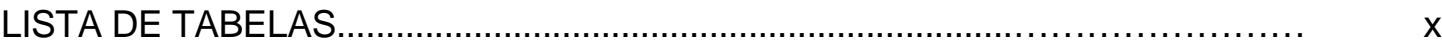

LISTA DE ABREVIATURAS E SÍMBOLOS............................................... xi

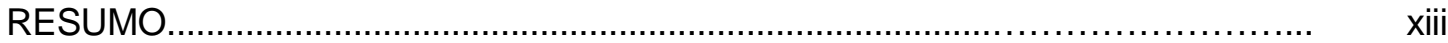

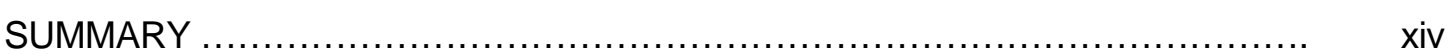

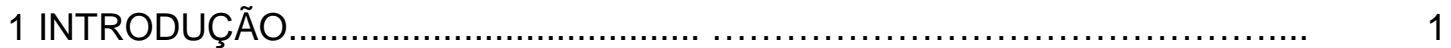

1.1 Apresentação ....................................................................... 1

1.1.1 A minha história pessoal e a deste trabalho............................... 1

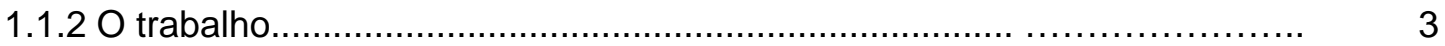

1.2 Considerações iniciais.............................................................. 4

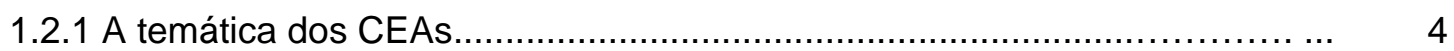

1.2.2 Relevância da área e do estudo ...................................................... 8

1.2.3 Problemas, hipóteses e objetivos ............................................. 9

2 REVISÃO DE LITERATURA ...................................................... 14

2.1 Centros de Educação Ambiental: afinal, o que são CEAs? .......................... 14

2.1.1 Histórico dos Centros de Educação Ambiental no Brasil........................... 25

2.1.1.1 Antecedentes ........................................................ 27

2.1.2 Algumas considerações sobre Educação Ambiental (EA), Ambientalismo

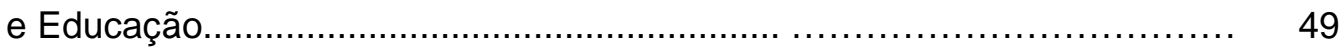

2.1.2.1 Educação Ambiental: fortalecendo caminhantes ........................ 51

2.1.2.2 Ambientalismo: uma luta continuada pela participação .................... 54

2.1.2.3 Educação: por uma práxis dialógica ........................................ 56 
2.1.3 Por uma participação dialógica nas práticas de CEAs 59

2.1.4 Projeto político-pedagógico na perspectiva de CEAS 62

2.1.5 Sobre tipologias de CEAs......................................................... 67

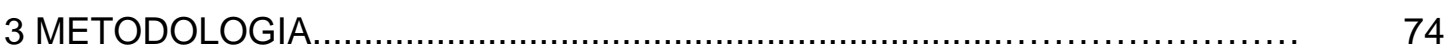

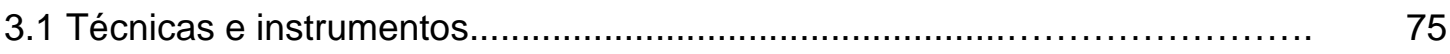

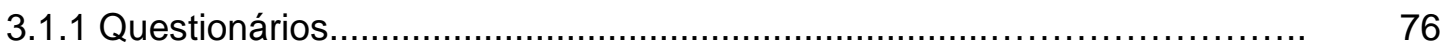

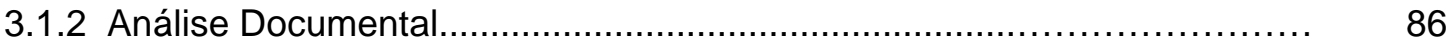

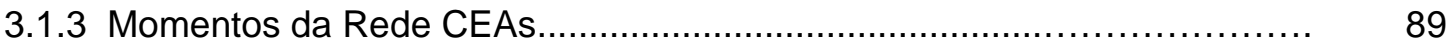

3.1.4 Tabulação e análise dos dados.................................................... 95

3.1.5 Processo de tipologização.......................................................... 96

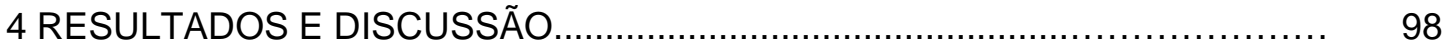

4.1 Proposta de classificação tipológica de CEAs Brasileiros........................ 98

4.2 Uma panorâmica de CEAs no Brasil................................................... 105

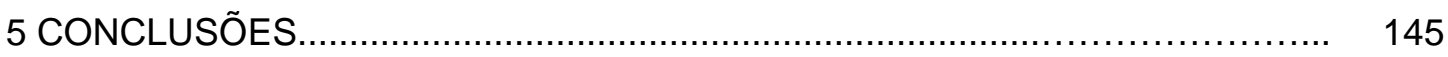

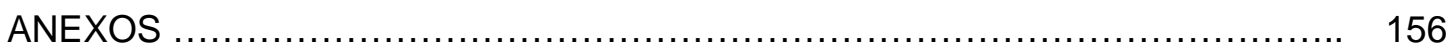

REFERÊNCIAS BIBLIOGRÁFICAS .................................................... 186 


\section{LISTA DE FIGURAS}

Página

1 Dimensões relativas à concepção de CEA adotada ........................ 20

2 Fases se surgimento dos CEAs no Brasil .................................. 27

3 Distribuição das instituições na Listagem Amostral …......................... 81

4 Esquema do processo simples de tipologização ….......................... 97

5 Distribuição dos CEAs nas Classes propostas ............................... 102

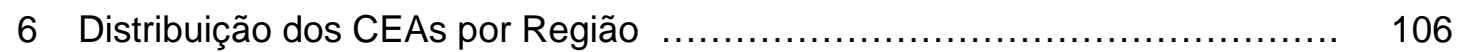

7 Distribuição dos CEAs por Unidades Federativas ............................. 108

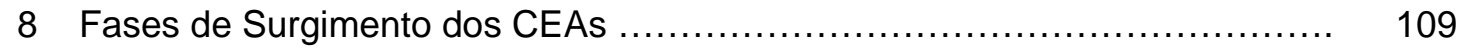

9 Disponibilidade de Correio Eletrônico nos CEAs .............................. 110

10 Localização dos CEAs .................................................. 111

11 Gestão dos CEAs ................................................... 112

12 Procedência da verba dos CEAs ....................................... 113

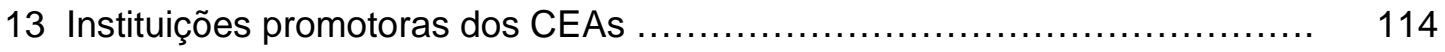

14 Características do Edifício-sede dos CEAs ................................ 115

15 Relação de Espaços disponíveis nos CEAs .............................. 116

16 Características do Entorno dos CEAs ...................................... 117

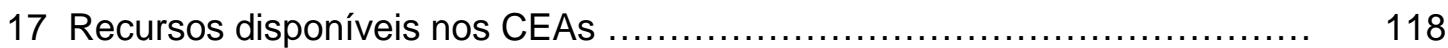

18 Produção de materiais nos CEAs .......................................... 119

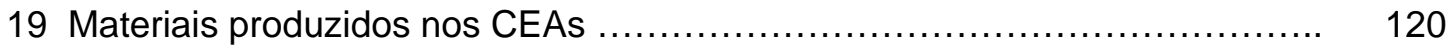

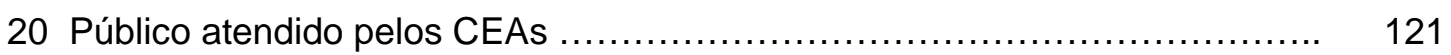

21 Procedência do público atendido ............................................ 122

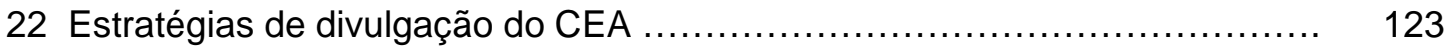


23 Público Atendido anualmente

124

24 Membros da equipe educativa dos CEAs

126

25 Formação dos membros das equipes educativas

26 Atividades mais freqüentemente realizadas pelos CEAs

27 Combinações de atividades mais freqüentes dos CEAs 129

28 Duração das atividades desenvolvidas nos CEAs 130

29 Temas trabalhados nos CEAs 131

30 Projeto Político Pedagógico nos CEAs 132

31 Alegações para não existência de um PPP. 133

32 Descrição do PPP em linhas gerais 134

33 Formas de avaliação das atividades dos CEAs 136

34 Formas de avaliação do CEA 137

35 Concepções sobre o tema "Biodiversidade" 139

36 Dificuldades enfrentadas pelos CEAs 140

37 Perspectivas dos CEAs para os próximos 5 anos 141

38 Avaliação do Questionário 1 143

39 Avaliação do Questionário 2 143 


\section{LISTA DE TABELAS}

Página

1 Fases de surgimento dos CEAs no Brasil ................................ $\quad 26$

2 Principais critérios e classificações tipológicas de CEAs Espanhóis ......... 69

3 Características principais das distintas "tendências" de CEAs espanhóis ... 72

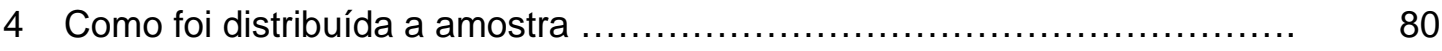

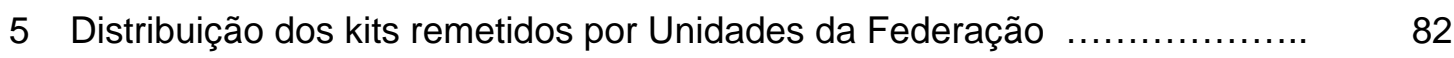

6 Distribuição dos kits remetidos por Região ............................... 83

7 Distribuição dos kits retornados por Unidades da Federação .................. 84

8 Distribuição dos kits remetidos por Região ................................ 85

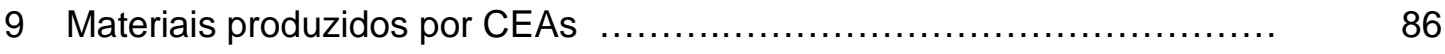

10 Classificação Tipológica de CEAs brasileiros ............................. 99 


\section{LISTA DE ABREVIATURAS E SÍMBOLOS}

\begin{tabular}{ll} 
CEA & Centro de Educação Ambiental \\
CEAs & Centros de Educação Ambiental \\
CENEAM & Centro Nacional de Educación Ambiental \\
CHESF & Companhia Hidrelétrica do São Francisco \\
CNEA & Conferência Nacional de Educação Ambiental \\
CNMA & Conferência Nacional do Meio Ambiente \\
EA & Educação Ambiental \\
EEA & Equipamento de Educação Ambiental \\
EEAs & Equipamentos de Educação Ambiental \\
EMBRAPA & Empresa Brasileira de Pesquisa Agropecuária \\
ENCEAs & Encontro Nacional de Centros de Educação Ambiental \\
EPCEAs & Encontro Paulista de Centros de Educação Ambiental \\
ESALQ & Escola Superior de Agricultura "Luiz de Queiroz" \\
FAPESP & Fundo de Amparo à Pesquisa do Estado de São Paulo \\
IBAMA & Instituto Brasileiro do Meio Ambiente e dos Recursos Naturais \\
& Renováveis \\
INEP & Instituto Nacional de Estudos e Pesquisas Educacionais \\
MEC & Ministério da Educação \\
MMA & Ministério do Meio Ambiente \\
NREA & Núcleo Regional de Educação Ambiental \\
ONG & Organização Não Governamental \\
ONEA & Organização das Nações Unidas \\
\hline Organização da Sociedade Civil de Interesse Público \\
Política Nacional de Educação Ambiental
\end{tabular}


PNUMA Programa das Nações Unidas para o Meio Ambiente

PRONEA Programa Nacional de Educação Ambiental (versão 1994-1998)

ProNEA Programa Nacional de Educação Ambiental (versão 1999-...)

REBEA Rede Brasileira de Educação Ambiental

Rede CEAs Rede Brasileira de Centros de Educação Ambiental

REPEA Rede Paulista de Educação Ambiental

SIBEA Sistema Brasileiro de Informação sobre Educação Ambiental

UC Unidade de Conservação 


\title{
HISTÓRICO, CLASSIFICAÇÃO E ANÁLISE DE CENTROS DE EDUCAÇÃO AMBIENTAL NO BRASIL
}

\author{
Autor: FÁBIO DEBONI DA SIVA
}

Orientador: Prof. Dr. DALCIO CARON

\section{RESUMO}

Este estudo buscou mapear Centros de Educação Ambiental (CEAs) de todas as regiões brasileiras com o objetivo de levantar subsídios para entender as origens desse movimento, quais suas interfaces com a literatura do ambientalismo e da educação ambiental brasileira; pontuar o que são os CEAs na atualidade, o que fazem, como e para quem; para propor quais as principais categorias de CEAs existentes no país, como eles dialogam com princípios-chave do movimento ambientalista e da educação ambiental; dentre outras características no tocante à temática dos CEAs na atualidade. Foram enviados dois questionários a uma base de dados de 500 instituições do campo da Educação Ambiental, retornando 101 respondidos por Centros de Educação Ambiental de 23 Unidades Federativas brasileiras. Esta foi a amostra trabalhada, o que possibilitou maior segurança nas discussões e análises tecidas. Concluiu-se que há uma diversidade de tipos de CEAs, sendo possível a proposição de oito classes, cada uma delas com foco de atuação distinto. Também se verificou e se experimentou a possibilidade de adoção de processos simples e complexos para a construção de classificações tipológicas para este tipo de iniciativas. Constatou-se um preocupante distanciamento entre o discurso e a prática dos CEAs no tocante a dois princípios-chave adotados - diálogo e participação. Há uma concepção simplificada do papel potencial que CEAs podem cumprir no cenário da educação ambiental brasileira. 


\title{
HISTORY, CLASSIFICATION AND ANALYSIS OF ENVIRONMENTAL EDUCATION CENTERS IN BRAZIL
}

\author{
Author: FÁBIO DEBONI DA SIVA \\ Adviser: PROF. DR. DALCIO CARON
}

\section{SUMMARY}

This study looked for mapping the Environmental Education Centers (EEC's) from all Brazilian regions aiming gathering assistance in order to understand the origins of this movement and which are its interfaces with the environmentalism and with the Brazilian environmental education literature. It also aimed defining the EEC's nowadays, what, how and to whom they do it in order to propose which are the main categories of EEC's in the country, how they relate to the main principles of the environmental movement and to the environmental education. Other features in relation to the EEC's themes nowadays were also aimed. Two questionnaires were sent to the database of 500 institutions from the Environmental Education field. From this amount, 101 questionnaires answered by the Environmental Education Centers from 23 Brazilian Federative Units were sent back. This was the sample used in this work, making possible safer discussion and analyses. It is concluded that there is a diversity of types of EEC's, being possible the proposition of eight classes, each one with a distinct focus. The possibility of adoption of simple and complex processes for the construction of a type classification for this kind of initiative was also verified and experimented. It was noticed a worrying distance between the speech and the practice of the EEC's in relation to two key principles adopted - dialog and participation. There is a simplified conception of the potential role that the EEC's can have on the Brazilian Environmental Education scenario. 


\section{INTRODUÇÃO}

\subsection{Apresentação}

\subsubsection{A minha história pessoal e a deste trabalho}

Meu envolvimento pessoal e profissional com a temática dos Centros de Educação Ambiental (CEAs) inicia-se em meados de 1999, a partir da atuação como estagiário numa pesquisa de levantamento de CEAs no Brasil, desenvolvida pela OCA/Laboratório de Educação e Política Ambiental e coordenada pela então acadêmica de Engenharia Agronômica Flávia Londres Cunha (até recentemente responsável pela Campanha "Por um Brasil livre de transgênicos", da rede AS-PTA). Pode ser considerado pouco tempo tendo como referência minha trajetória de vida e a "história" dos CEAs brasileiros, entretanto, pode ser um tempo relativo se considero que estou falando sobre uma temática consideravelmente pouco conhecida no âmbito acadêmico, a qual dispõe de um repertório teórico bastante restrito.

O fato é que, a partir da minha participação na referida pesquisa, a temática dos Centros de Educação Ambiental começou a despertar, concomitantemente, meu interesse/motivação e inquietação/dúvida. Como uma área no campo da Educação Ambiental tão relevante e com tanto potencial poderia estar tão desguarnecida de informações, dados, repertório? Quais os motivos que levavam os CEAs a não serem considerados, inclusive entre educadores ambientais, como importantes instrumentos para o desenvolvimento de ações educacionais voltadas à questão ambiental? Não tenho qualquer pretensão de responder a estas questões e a outras que emergiram (e que emergem cotidianamente), mas as considero importantes indagações norteadoras da minha prática profissional.

No período de 2000 a 2001, estive envolvido com o desenvolvimento de um projeto de iniciação científica intitulado "Centros de Educação Ambiental no Brasil - O estado da arte", financiado pela FAPESP. Acredito ter sido por meio desta pesquisa 
que se deu minha real introdução nesta temática, possibilitando-me conhecer algumas iniciativas brasileiras de CEAs e estudá-las com maior profundidade. Considero-a especialmente relevante por permitir verificar que um trabalho que se propusesse a identificar o "estado da arte" desta temática num país como o Brasil, requereria maior amadurecimento intelectual e profissional além de mais tempo de pesquisa e maior disponibilidade de recursos, características, obviamente, não condizentes com projetos de iniciação científica. Por outro lado, o estudo suscitou-me diversas reflexões, dentre elas, a de que os CEAs brasileiros eram mais complexos e mais diversos do que pensava, mas que guardavam algumas semelhanças entre si, passíveis de permitir um trabalho "taxonômico" posterior (embora esta vertente, nesse momento, ainda não estivesse plenamente amadurecida).

Desde o início da elaboração do projeto de iniciação científica tive contato com algumas obras espanholas que tratavam da temática naquele país. Foi, sobretudo, a partir das diversas leituras de Pérez (1995), o qual faz um breve apanhado dos CEAs espanhóis $^{1}$ com especial enfoque na questão da avaliação qualitativa, que fui descobrindo outras abordagens sobre os CEAs e criando uma considerável identificação com elas. A descoberta de algumas publicações do Centro Nacional de Educação Ambiental² (CENEAM), iniciativa promovida e gerida pelo governo federal espanhol, contribuiu para ampliar meu repertório sobre a temática, em especial o Guia de Recursos e de Materiais para a Educação Ambiental ${ }^{3}$, um banco de dados que permite obter informações sobre todos os CEAs da Espanha, acessando suas características principais (localização, contatos, público que atende, atividades que realiza, etc).

O contato com tais materiais e autores foi proporcionando uma importante oportunidade de realizar um estágio profissionalizante na Espanha, com o intuito de finalizar meu curso de graduação, realizando um breve levantamento de iniciativas de CEAs que atuassem na interface com o campo da agroecologia. A partir do final de 2000, iniciei uma série de contatos com o Prof. Pablo Angel Meira Cartea, da Universidade de Santiago de Compostela, para viabilizarmos o estágio. Desde o começo deste contato tive a feliz impressão de que a oportunidade se concretizaria,

\footnotetext{
${ }^{1}$ Intitulado, no país, Equipamientos de Educación Ambiental (EEA)

${ }^{2}$ Há uma grande disponibilidade de informações no site do CENEAM: http:// www.mma.es/ceneam

${ }^{3}$ O Guia pode ser solicitado através do e-mail: info@ceneam.mma.es.
} 
pois houve muita disposição do Prof. Pablo e da instituição em viabilizar meu deslocamento para lá.

Na segunda metade de 2001 eu embarcava para a Espanha a fim de desenvolver um projeto de Estágio Profissionalizante. Basicamente, iria levantar informações sobre CEAs, em especial daqueles que atuassem com a temática da agroecologia, e iria realizar atividades de campo em CEAs selecionados e que se dispusessem a me receber. Apesar de ter ficado apenas três meses na Espanha, considerei plenamente satisfatório o estágio, porque além de permitir implementar a proposta, tive o privilégio de conhecer e de entrevistar alguns especialistas no assunto $^{4}$, e de levantar considerável repertório de materiais.

Durante o desenvolvimento do projeto de estágio profissionalizante e, à medida que eu estabelecia contato com materiais, através de incansáveis revisões bibliográficas, fui construindo a proposta de um projeto para o mestrado. De fato, a idéia deste projeto foi vislumbrada na Espanha, mais especificamente, nas terras chuvosas e acolhedoras da Galícia.

\subsubsection{O trabalho}

Esta dissertação está organizada da seguinte forma:

Capítulo 1 - Refere-se à Introdução e destina-se à apresentação dos motivos que conduziram a realização da pesquisa, compreendendo, ainda, a problemática, as hipóteses e os objetivos da mesma.

Capítulo 2 - Neste espaço o leitor poderá acessar alguns aportes conceituais relativos à temática dos Centros de Educação Ambiental brasileiros: o que são CEAs; breve histórico destas iniciativas; educação ambiental, movimento ambientalista e educação; participação, diálogo e CEAs; e projeto político pedagógico.

Capítulo 3 - Neste capítulo o leitor conhecerá quais os procedimentos metodológicos adotados nesta pesquisa, em todas as suas etapas, tais como: levantamento de informações, tabulação, análise dos dados e tipologização.

Capítulo 4 - Refere-se a apresentação dos Resultados e Discussão, em que serão encontrados os dados levantados, trabalhados e interpretados nesta pesquisa,

\footnotetext{
${ }^{4}$ Como, por exemplo: Oscar Cid (Diretor do Campo de Aprendizagem do Delta do Ebro, um CEA importante da Catalunha); Prof. José Gutiérrez Pérez (Universidade de Granada); Paco Heras (Centro Nacional de Educação Ambiental - CENEAM); Prof $^{a}$. Araceli Serantes Pazos (Universidade de Coruña).
} 
basicamente, de duas formas: uma primeira relativa às classificações tipológicas propostas por este trabalho; e uma segunda com uma panorâmica dos CEAs no Brasil, o que possibilita ao leitor situar-se nesse universo bastante complexo e diversificado de iniciativas.

Capítulo 5 - O trabalho encerra-se, enfim, neste capítulo onde, além de buscar responder às perguntas essenciais deste estudo, também são enunciadas algumas novas questões que ficam para trabalhos futuros relativos à temática dos CEAs.

\subsection{Considerações iniciais}

\subsubsection{A temática dos CEAs}

Estudar a temática dos Centros de Educação Ambiental no Brasil consiste em tarefa ingrata e provocante. Ingrata porque qualquer pesquisador que se proponha a buscar trabalhos, artigos e publicações diversas relativas a este tema, na atualidade, logo percebe a considerável lacuna que há a despeito de todo o acúmulo já conquistado no campo da Educação Ambiental brasileira. Se este já acumulou diversas discussões, traduzidas em publicações e manifestações das mais variadas possíveis, não se pode afirmar o mesmo para a temática dos CEAs. Estudar esta temática passa a ser, então, uma missão extremamente provocante, estimulante e motivadora para o desenvolvimento de estudos e trabalhos como este, que possam contribuir para a abertura de "picadas" no complexo campo da Educação Ambiental.

Se dentro do próprio meio - o de educadores ambientais - há considerável carência de repertório teórico e de acúmulo conceitual sobre a temática chave deste trabalho, o que dizer de outros campos relativos à área ambiental brasileira? Sabe-se que ela encontra-se em franca expansão em termos de horizontes de atuação profissional, de perspectivas de desenvolvimento de estudos e pesquisas (desde estudos de caso até amplos diagnósticos) e de estabelecimento de canais de diálogo com diversas outras áreas correlatas (a tão chamada "transversalidade 5" da questão ambiental).

\footnotetext{
${ }^{5}$ Para mais informações sobre o assunto, consultar a obra de Nicolescu (1999), que aborda sobre as distintas terminologias adotadas em alusão ao conceito trazido pelo termo.
} 
No campo da EA, embora também novo e desprovido de estudos, debates e análises mais aprofundadas em muitos de seus "sub-campos" e em áreas correlatas com as quais estabelece permanente diálogo $0^{6}$, há, inequivocamente, um cenário atual bastante rico e animador. De fato, o momento atual aponta para o desenvolvimento de inúmeras iniciativas de $\mathrm{EA}^{7}$ nas diversas regiões do país, pelo e para distintos públicos, sob a tutela e o acompanhamento de uma gama considerável de instituições, com uma série de especificidades e aí por diante. Sem dúvida, trata-se de um campo, no Brasil deste início de século XXI, que se encontra em sua "nova geração", com notáveis conquistas, acúmulos e avanços. Contudo, trata-se de um campo em permanente (re)constituição, (re)criação e que esboça sua fragilidade em diversos momentos.

O desafio de adentrar numa área nebulosa e pouco mapeada dentro do campo da EA gerou, num primeiro momento, incerteza e perplexidade. Eram muitas as questões que emergiam para serem debatidas com a árdua missão de concretização de respostas factíveis. No entanto, o também desafio de ser sujeito de todo o processo deste estudo, que culminou nesta dissertação, não foi encarado com insegurança ou receio. Muito pelo contrário, tratava-se de aprofundar estudos de um campo não totalmente obscuro, junto ao qual se vislumbrava algum horizonte de possibilidades que, obviamente, deveriam ser decodificadas para serem analisadas com a profundidade necessária. A temática dos Centros de Educação Ambiental não era um "bicho de sete cabeças" que deveria ser dissecada para o desenvolvimento deste estudo. Ao contrário, a idéia desta pesquisa foi sendo pensada e delineada, ainda que de uma forma dispersa e fragmentada, há no mínimo três anos. Não surgiu às vésperas da inscrição para o programa de pós-graduação. Já havia uma clareza da idéia-mãe deste estudo, da sua concepção principal e nuclear bem como dos problemas que se queria desvendar. Estes estavam mais ocultos e, em alguns momentos, até "fugiam" e se "confundiam", mas orientaram o desenrolar do trabalho desde o início e foram fundamentais para o seu pleno desenvolvimento.

\footnotetext{
${ }^{6}$ Por exemplo, há lacunas no campo da EA no que trata da sua relação com movimentos e organizações de juventude; no campo referente a indicadores de avaliação e monitoramento de programas, projetos, políticas e ações; dentre outros.

7 Incluem-se aí aquelas que se consideram como sendo iniciativas de EA, cabíveis, no entanto, de crivos mais criteriosos, que não é a missão deste trabalho.
} 
Agregam-se a estas motivações que qualquer pesquisador teria - de avidez pelo conhecimento (pela sua produção, por conhecer o próprio conhecimento e todas as suas implicações, etc) - aspirações de caráter eminentemente político (não partidário); de questionamento pelo "modus vivendis" atual, de aspirações por mudanças na sociedade, de clareza nas mútuas implicações políticas no campo da EA e da produção do conhecimento, de luta pela promoção de processos educacionais emancipatórios, críticos, e movidos pela permanente construção de sociedades ecologicamente prudentes e cuidadosas, socialmente justas, politicamente ativistas e economicamente eficientes.

Partindo dos pressupostos mencionados buscou-se, desde o início, forjar um espírito de respeito pelos chamados, no meio acadêmico, "objetos de pesquisa" e, sobretudo, um caráter de reciprocidade, considerando os deveres da universidade para com o conjunto da sociedade. Há, então, uma sintonia com o que aponta Demo (2002, p.33):

"uma tese de mestrado pode admitir "cuidados qualitativos" com maior facilidade quando o pesquisador se esforça por tratar a comunidade com respeito, devolve a ela os dados colhidos, convive certo tempo com ela, facilita o processo de formação política e assim por diante. Assim como um pesquisador utiliza a comunidade - ainda que com respeito -, a comunidade pode utilizar o pesquisador, transformando em iniciativas práticas os resultados da pesquisa. Isto, no entanto, não precisa necessariamente levar o pesquisador a adotar o projeto político da comunidade”.

Este caráter, mencionado na passagem acima, foi sendo construído ao longo do desenvolvimento deste trabalho, mas não se inicia com ele. Desde o início do meu envolvimento com a temática esta preocupação, sempre esteve presente e foi sendo retroalimentada com resultados de pesquisas e com o meu envolvimento em trabalhos e projetos anteriores. Diversos contatos com CEAs do país foram sendo construídos a partir de 1999, mas com maior consistência a partir de 2000 devido ao desenvolvimento da pesquisa de iniciação científica, o que possibilitou vislumbrar os desafios existentes pela frente e, também, as potenciais parcerias que poderiam ser efetivadas. 
Estas possibilidades foram ganhando corpo e forma na medida em que o presente trabalho ia avançando. Profissionais, educadores, instituições, redes, constituíam-se em potenciais parceiros e interessados no desenvolvimento deste estudo. Coletivos organizados, como a Rede Brasileira de Educação Ambiental $\left(\mathrm{REBEA}^{8}\right)$; a Rede Paulista de EA (REPEA $\left.{ }^{9}\right)$ dentre outras redes ligadas ao campo da EA brasileira, constituíram-se desde o início, em parceiros fundamentais para o desenvolvimento desta pesquisa. Em contrapartida foram estabelecendo-se canais de diálogo, trocas de informações, contatos e diversas outras oportunidades que contribuíam para o enriquecimento dos envolvidos.

À medida que se levantavam os dados deste estudo percebeu-se a riqueza que eles poderiam representar para o campo da EA brasileira. Sem falsas pretensões, acredito que este estudo constitui-se num "desbravador" de uma nova trilha no campo da EA. Se desde o princípio havia clareza da necessidade e do compromisso da disponibilização e retorno das informações levantadas por este trabalho, não havia, no entanto, certeza quanto aos meios a serem adotados para atingir tal objetivo. Idéias diversas surgiram, mas somente com o pleno envolvimento com as redes mencionadas acima é que foi sendo percebida uma alternativa interessante e que vinha bem ao encontro da colocação de Pedro Demo. Uma alternativa que servisse de estímulo para promover uma efetiva contribuição no que diz respeito à formação política dos educadores e demais profissionais que atuam em CEAs no Brasil da atualidade era o que se buscava. Além de um mero retorno dos dados gerados pela pesquisa, o fomento ao estabelecimento de uma Rede que tivesse como objetivo a união destas pessoas e instituições em prol da discussão de questões inerentes ao cotidiano dos CEAs, mediante a troca de informações e de experiências, dentre outras possibilidades. Emerge daí a Rede Brasileira de Centros de Educação Ambiental - a Rede CEAs ${ }^{10}$-, que iniciou sua trajetória ao final de 2002. Trata-se de uma iniciativa "caseira" que, como qualquer rede, padece de inúmeras dificuldades para se consolidar e que se encontra em franco processo de formação e consolidação, na atualidade.

A Rede CEAs surge com uma missão importante, a de estimular a troca de informações e de experiências entre os distintos CEAs atuantes no país, contribuindo

\footnotetext{
${ }^{8}$ http://www.rebea.org.br

${ }^{9}$ http://www.repea.org.br

${ }^{10}$ http://www.redeceas.esalq.usp.br
} 
para fortalecer os processos educacionais que desenvolvem. Emerge com propostas de reflexão quanto às concepções recorrentes de CEAs, inclusive com preocupações relativas à construção de políticas públicas. Trata-se de um conjunto de objetivos bastante amplos e consideravelmente complexos para serem alcançados.

Se, por um lado observamos que há grandes desafios delimitados, á nossa frente vislumbramos um panorama bastante propício a avanços, terreno fértil a propostas e projetos que dialogam com tais objetivos. Propício a ponto de possibilitar importantes avanços, considerando que se trata de uma iniciativa caseira, que inicia sua trajetória de maneira tímida e quase sem apoios.

\subsubsection{Relevância da área e do estudo}

Trata-se de uma área dentro do campo da EA com consideráveis potencialidades de atuação por diversos motivos. Refere-se a iniciativas que dispõem de estrutura física para o desenvolvimento dos mais variados tipos de atividades de EA, que vão desde a simples disponibilização de informações ambientais passando pelo oferecimento de trilhas de interpretação da natureza, até o estímulo à organização local comunitária para a participação em processos políticos de intervenções socioambientais na realidade. Configuram-se em iniciativas que podem centrar sua atuação em finalidades bem distintas, como por exemplo:

- Disponibilização de informações;

- Estímulo aos processos de reflexão crítica sobre os problemas ambientais atuais e a revisão de valores;

- Promoção de ações de caráter formativo;

- Desenvolvimento de atividades interpretativas e de sensibilização, e de contato com a natureza;

- Delineamento e implementação de projetos, consultorias, eventos diversos;

- Articulação com entidades e pessoas para potencializar ações comunitárias locais (politicamente/ideologicamente);

- Constituir-se em espaço de lazer e ócio e/ou de realização de atividades lúdicas e culturais; 
- Desenvolvimento de projetos de pesquisa e de produção de conhecimento.

É possível visualizar a gama de possibilidades que os CEAs podem realizar. Pode ser considerada como sendo uma área estratégica no campo da EA pela diversidade de instituições ligadas aos mais diversos setores da sociedade que promovem e/ou que mantêm iniciativas atuantes no país:

- Segmento governamental (órgãos federais, ministeriais, estatais, governos estaduais, prefeituras, secretarias, institutos, fundações, batalhões de polícia, etc). Ex: MEC, IBAMA, CHESF, Petrobrás;

- Setor Privado (empresas de diversas áreas, fundações de empresas, bancos, pequenas e médias empresas, dentre outras instituições);

- Organizações do Terceiro Setor (ONGs, Associações, OSCIPs, etc);

- Centros de Pesquisa/Universidades (públicas e privadas). Ex: EMBRAPA, diversas universidades e faculdades;

- Mistas (instituições de mais de um desses segmentos estão envolvidas na proposta). Ex: MMA financia a obra do CEA e uma ONG é responsável pela sua gestão.

Todo este cenário possibilita-nos visualizar a relevância da temática dos CEAs para o campo da EA brasileira apontando, ainda, para a possibilidade deste estudo contribuir para que educadores ambientais, profissionais da área ambiental, formadores de opinião, potenciais educadores, e a sociedade em geral possam apropriar-se de informações sistematizadas sobre estas iniciativas, de modo a estimular discussões sobre questões, até certo ponto, ainda básicas sobre elas.

\subsubsection{Problemas, hipóteses e objetivos}

Este trabalho procura discutir e construir reflexões e considerações que contribuam para o enfrentamento de algumas indagações essenciais, também denominadas como problemas, mas que aqui se considera como questões provocadoras e orientadoras do estudo. São basicamente três blocos de questões: 
1. "Afinal, o que são CEAs? O que fazem? Qual sua finalidade? Quais seriam os elementos mínimos para uma iniciativa ser considerada como sendo um CEA? Qual sua situação atual? Como estão distribuídos no país?"

2. "Há convergência entre os marcos/fatos históricos do movimento ambientalista e da Educação Ambiental e os de criação dos Centros de Educação Ambiental no Brasil?"

3. "É possível criar classificações tipológicas de CEAs brasileiros a partir da adoção de princípios da EA e do movimento ambientalista?"

Cabe salientar que a primeira questão não estava posta no plano inicial de pesquisa, mas foi emergindo a partir das contribuições e indagações que o processo de revisão teórica ia suscitando. À medida que se colhia informações a respeito da conceituação de CEAs, percebia-se o quanto esse campo era pobre e "pantanoso" e que deixava mais dúvidas do que respostas concretas. A partir de então, passou-se a delinear uma nova pergunta/problema para a presente pesquisa: Afinal, o que são estas iniciativas intituladas de Centros de Educação Ambiental? O que fazem? Como fazem? Quais suas características principais? Que dimensões são essenciais para uma determinada iniciativa ser considerada com CEA? Qual sua situação atual? Como se encontram distribuídos no país? Há uma lógica de distribuição segundo alguns critérios?

Estas são questões essenciais para o trabalho que, por se tratar de uma área temática totalmente nova no conjunto da Educação Ambiental, mereciam ser incluídas para serem discutidas e aprofundadas. À medida que a revisão teórica avançava e não possibilitava que se obtivesse respostas a tais indagações foi preciso, então, buscar outro caminho para solucionar este problema. Ele poderia emergir, então, da realização de um amplo diagnóstico junto às distintas iniciativas de CEAs em atividade no Brasil. Sendo que a realização deste levantamento poderia, também, contribuir para o enfrentamento de parte das outras questões-problema deste estudo, como de fato contribuiu.

Simultaneamente à visualização destas três questões-problema, foi possível a proposição das seguintes hipóteses:

- Há considerável diversidade de "tipos" e concepções de CEAs no Brasil; 
- O papel dos CEAs na construção de sociedades sustentáveis pode ser estudado a partir da definição de sua relação com pressupostos e princípios do ambientalismo e da educação ambiental;

- Os fundamentos da Educação Ambiental e os pressupostos do ambientalismo permitirão classificar os CEAs, de modo a facilitar o entendimento dos distintos "tipos" de iniciativas existentes.

Este estudo tem como objetivo geral contribuir para a ampliação do conhecimento na área para o fomento e divulgação da temática dos Centros de Educação Ambiental (CEAs) no país.

\section{Apresenta como objetivos específicos:}

1) Entender e configurar os movimentos que deram origem à formação dos primeiros CEAs no país e seus precursores, identificando suas características básicas, seus principais atores e respectivos papéis, momentos históricos, etc;

2) Construir e selecionar indicadores (critérios) que permitam uma ordenação em classes dos diferentes tipos de CEAs existentes no país;

3) Elaborar/compor um quadro de classificação tipológica destas iniciativas, que permitam visualizar suas principais características;

4) Montar um banco de dados dos CEAs relativos a cada classe tipológica, com o intuito de disponibilizar informações a respeito de cada CEA estudado;

5) Selecionar e conhecer em profundidade alguns CEAs pertencentes a cada classe tipológica proposta, de modo a avaliar se esta classificação corresponde à realidade, e adquirir embasamento para análise; e

6) Analisar e discutir algumas questões no tocante aos CEAs, dentre elas: como compreendem e como trabalham a temática da biodiversidade; quais concepções e objetivos conferem às suas iniciativas; quais as formas de avaliação mais empregadas e quem realiza esta tarefa; quais as concepções vigentes de um projeto político pedagógico de CEAs.

O objetivo específico de número 1 será abordado no item "Histórico dos CEAs no Brasil", o qual busca identificar e discutir as fases históricas dos CEAs no país, dialogando com os movimentos e fatos históricos do Ambientalismo e da Educação Ambiental brasileiros. 
Os objetivos 2 e 3 serão abordados nos itens "Sobre tipologias de CEAs"; "Processo de Tipologização" e "Classificação tipológica de CEAs", preservando os diferentes enfoques que cada um traz. O primeiro destes itens traz informações sobre as tipologias encontradas de Centros de Educação Ambiental na Espanha, suas principais categorias e os critérios adotados para propô-las, e constitui-se em importante ponto de partida para a evolução deste trabalho, sobretudo no tocante à construção de classificações tipológicas para os CEAs brasileiros. O segundo item ("Processo de tipologização") aponta para os procedimentos metodológicos adotados para a construção das classes tipológicas de CEAs brasileiros, as quais são apresentadas, por fim, no item "Classificação tipológica de CEAs", que identifica e discute as principais características de cada uma delas.

Com relação ao objetivo específico de número 4, há uma listagem dos 101 CEAs que contribuíram com este estudo. Como não se trata do escopo de uma pesquisa de mestrado a construção de banco de dados, este objetivo desde o início foi apresentado e entendido muito mais como um desdobramento deste trabalho, o que de fato ocorreu. A partir do mapeamento e contato com as mais diversas instituições e profissionais atuantes em CEAs e no campo da Educação Ambiental, foi se percebendo a possibilidade de articulação de uma rede que pudesse facilitar a organização das distintas iniciativas de CEAs atuantes no Brasil. Desta forma a proposta da Rede Brasileira de Centros de Educação Ambiental - Rede CEAs ${ }^{11}$ foi ganhando força, sendo que este banco de dados constitui uma forma de retorno dos dados levantados aos CEAs participantes deste estudo e à sociedade de uma forma geral.

O objetivo de número 5 não pôde ser cumprido como estava delineado, porque não houve recursos financeiros que viabilizassem percorrer alguns CEAs para conhecê-los com profundidade. Este fato, porém, não prejudicou substancialmente o trabalho, uma vez que se buscou suprir esta lacuna por meio da intensificação de contatos e troca de informações e de experiências com profissionais atuantes em CEAs através da participação de eventos do campo da EA (Simpósios, Encontros, etc) e reuniões das redes de EA, dentre outras ações. Merece destaque, sobretudo, a realização de quatro eventos de considerável relevância para a temática central deste

\footnotetext{
${ }^{11}$ Há um banco de dados disponível na página da Rede CEAs com informaçoes dos CEAs aqui estudados e de outros que, embora não tenham participado desta pesquisa, estão inserindo seus dados diretamente no site http:// www.redeceas.esalq.usp.br
} 
estudo: a) Encontro Paulista de CEAs (EPCEAs), realizado pela Rede Paulista de Educação Ambiental, durante os dias 23 a 25 de julho de 2003, em Rio Claro; b) I e II Encontro de CEAs do Estado do Rio de Janeiro, realizados respectivamente em 2003 e 2004, nas cidades de São Gonçalo e Rio de Janeiro; e c) Encontro Nacional de CEAs (ENCEAs) organizado pela Rede CEAs, Fundação Acesita e CEA Oikós, nos dias 1 e 2 de outubro de 2003, em Timóteo - MG. Deste evento, resultou um documento denominado "Carta de Timóteo" (Anexo C) que traz, além de conceituações importantes para a temática, algumas resoluções.

Enfim, o objetivo 6, que remete para a análise e discussão de algumas questões relevantes para a atuação de CEAs no país, com especial atenção para as compreensões relativas à temática da biodiversidade, as estratégias avaliativas mais adotadas para acompanhar as atividades que os CEAs realizam e para avaliar o próprio CEA, e quais as concepções inerentes ao projeto político pedagógico destas iniciativas. Estas questões serão apresentadas e discutidas no item "Tabulação e análise dos dados - Diagnóstico dos CEAs no Brasil”, juntamente com uma gama de outros tópicos, não menos importantes, que possibilitam a visualização de um retrato dos CEAs brasileiros na atualidade. 


\section{REVISÃO DE LITERATURA}

\subsection{Centros de Educação Ambiental: afinal, o que são?}

Por ser uma temática que começa a despertar interesse, falar sobre Centros de Educação Ambiental (CEAs) num país como o Brasil constitui, na atualidade no mínimo, um enorme desafio. Não dispomos de qualquer estudo aprofundado que possa constituir-se em subsídio consistente para referenciar pesquisas neste campo. Talvez, por ainda nos encontrarmos num patamar bem inicial, onde sequer acumulamos discussões conceituais referentes à temática. Vislumbramos mais dúvidas do que respostas com relação a esta no país. A primeira delas, e porque não a fundamental, refere-se a questão básica: "O que são CEAs?"

A busca por publicações na literatura brasileira da área constitui tarefa ingrata, mas ao mesmo tempo instigante. Há carência de trabalhos, qualquer que seja sua abordagem e enfoque. Já nos deparamos com isso em outros momentos, especificamente em três estudos anteriores nos quais estivemos envolvidos (Silva, 2001; Silva, 2001 e Londres, 2002).

Embora haja carência de referenciais sobre a temática, não podemos afirmar que há ausência de trabalhos. Uma revisão na literatura identificou algumas referências que merecem ser consideradas. Um primeiro bloco relativo às primeiras publicações "oficiais" sobre CEAs, de responsabilidade do Ministério da Educação (MEC), que trazem propostas de fundamentação e de diretrizes para a implantação de CEAs no país. Na época em que foram publicadas havia uma idéia de que os CEAs deveriam constituir-se em centros difusores, catalizadores e irradiadores de experiências, informações, conhecimentos. Surgem, no entanto, ligados a uma concepção marcadamente formal da educação ambiental, vinculada ao ensino formal (escolar), e praticamente desconsiderando as experiências do chamado campo não formal da EA brasileira, como vemos no trecho abaixo: 
"Os centros de educação ambiental não seriam escolas ecológicas, mas sim centros geradores ou captadores de idéias e propostas. (...) A proposta é (...) utilizar o ensino formal que já temos, não criar nenhuma disciplina, com uma abordagem inter e multidisciplinar, e abrir a porta da escola (...) para envolver a comunidade (...) Nesse sentido, a idéia dessa proposta pedagógica do Centro de Educação Ambiental seria utilizar o programa curricular oficial e transcender o banco escolar, quer dizer, envolver o saber popular e complementar com a proposta curricular. Envolvendo o saber popular e o saber científico, o Centro seria catalizador e difusor desses conhecimentos" (Brasil, 1992, p.102).

Além destes trabalhos, encontramos também um artigo que relata a experiência de criação de um Centro de Referência em EA no município de São Carlos - SP, que centraliza seu foco mais no processo de informação do que no Centro em si. Ressalta alguns aspectos do Centro, descrevendo brevemente seus recursos (físicos, tecnológicos, informacionais, humanos e de marketing) e não traz uma concepção de Centro (Costa, 1997).

Identificamos, ainda, um trabalho da Secretaria do Meio Ambiente, do Governo do Estado de São Paulo, intitulado "Programas Núcleos Regionais de Educação Ambiental" (1998), que concebe estes Núcleos como,

"fóruns de integração e participação (...) para otimização dos recursos materiais, humanos e financeiros, tendo em vista o desenvolvimento de projetos e ações de educação ambiental que estimulem o exercício da cidadania, configurando-se, portanto, como um instrumento de ação e mecanismo para o fluxo de informações ambientais (...)" (São Paulo, 1998, p.4).

Por fim, encontramos o trabalho de Fernandes (2002) que fez um estudo com 13 empresas de mineração do Estado de Minas Gerais, analisando seus programas de EA, nos quais estão incluídos CEAs, e traçou diretrizes para o programa de uma destas empresas, a Companhia Brasileira de Metalurgia e Mineração (CBMM). O estudo é um Trabalho de Especialização que aborda parte da realidade brasileira, de 
Minas Gerais e que foi defendido no Reino Unido. Trata-se de um subsídio importante para o desenvolvimento da presente pesquisa.

No Brasil foram estas as principais referências encontradas na literatura ligada aos campos da Educação Ambiental e do Ambientalismo. Além destas, encontramos alguns poucos trechos que discorrem sobre a temática em publicações de Educação Ambiental no Brasil. Talvez a que nos traz mais elementos para contribuir para esse estudo é a de Dias (1998), a qual discorre sobre o I Encontro Nacional de Centros de Educação Ambiental, realizado em Foz do Iguaçu em 1992.

Este é o cenário com que nos deparamos no campo conceitual relativo à temática dos CEAs no Brasil. Por outro lado, vislumbramos um momento bastante propício ao surgimento e desenvolvimento destas iniciativas, que se apresentam com uma grande variedade de denominações e de "tipos", configurando um cenário multifacetado e complexo, que merece ser ilustrado e discutido.

Tendo este panorama como pano de fundo, esta pesquisa buscou "beber" e dialogar com referenciais teóricos e práticos de experiências, trabalhos, congressos, estudos, levantamentos e projetos de Centros de Educação Ambiental ${ }^{12}$ da Espanha. Optou-se então, pelo desenvolvimento do presente estudo tendo como "norte" algumas obras e autores ${ }^{13}$ considerados "chaves" neste campo, na Espanha, com os quais este texto busca intercambiar formas de olhar, interpretar, refletir e propor sobre a temática em questão.

Mas, afinal o que são CEAs? Como elucidado pouco antes, esta conceituação teórica será construída tendo como ponto de partida as referências espanholas. Iniciaremos, então, por um documento denominado Estratégia Andaluzia de Educação Ambiental, o qual aponta que:

"Sob o termo Centros de Educação Ambiental (CEA) se englobam todas aquelas iniciativas que, contando com instalações próprias ou cedidas ${ }^{14}$ e equipes pedagógicas especializadas, desenvolvem programas específicos de educação ambiental relacionados com o entorno onde se localizam" (2003, p.73).

\footnotetext{
12 Denominados, no país, como Equipamientos de Educación Ambiental (EEAs).

13 Como, por exemplo: José Gutiérrez Pérez (1994, 1995, 1998), Oscar Cid (1992, 1998), Araceli Serantes Pazos (2001), Seminários Permanentes de Educación Ambiental (1996), Guia de Recursos para la Educación Ambiental - CENEAM (2001) e Estrategia Andaluza de Educación Ambiental (2003).

${ }^{14}$ Grifo nosso
} 
Também encontramos contribuição importante de Pérez (1994), que propõe que os CEAs possuam, no mínimo:

a) Um projeto educativo que explicita os princípios educativos e ambientais sobre os quais se assenta, assim como os objetivos que persegue, as metodologias que aplica, as atividades que realiza, os recursos que utiliza e os coletivos de destinatários aos quais se oferece;

b) Uma equipe de profissionais, devidamente qualificados e em número suficiente para atender às demandas dos diversos coletivos de usuários aos quais se dirige;

c) Espaços organizados localizados em paisagens rurais, espaços naturais ou espaços urbanos, que constituem cenários pedagógicos adequados para a consecução de seus objetivos em função da tipologia de destinatários. Estes espaços podem ter sido criados especificamente em função do Projeto Educativo ou bem podem utilizar-se instalações e infra-estruturas desenhadas para outros fins, mas que se adequem e garantam o desenvolvimento do Projeto;

d) Recursos e materiais adequados para a realização das atividades previstas no Projeto Educativo e coerentes com os princípios da Educação Ambiental;

e) Uma estratégia avaliativa adequada a sua planificação, instrumentos e agentes que, contidas no Projeto Educativo, explicita quem, como e quando se avaliam os programas desenvolvidos de modo que se garanta a retroalimentação do Projeto.

Se a Estratégia Andaluza de EA esforçou-se em apresentar, sucintamente, uma proposta de conceituação da temática Pérez procurou, esquematicamente, discorrer sobre as principais dimensões essenciais para qualquer iniciativa que pretenda ser um Centro de Educação Ambiental na Espanha, merecendo destaque por:

1. Ressaltar a dimensão de um Projeto Educativo que explicite não só o programa de atividades que realiza, mas que aponte os princípios com os quais dialoga, as metodologias adotadas, os objetivos que alicerçam 
sua atuação, interagindo com os recursos disponíveis e o tipo de público com o qual se deseja trabalhar;

2. Apontar para a necessidade de se dispor de uma Equipe de Profissionais, minimamente qualificada, para o desenvolvimento das atividades do CEA, e em número suficiente para tal. É preciso organizar a equipe, levando-se em consideração as dimensões quantitativas (quantos técnicos na equipe) e qualitativas (de que área, com qual perfil e habilidades). É importante ressaltar que não há formulas prontas para esse "dimensionamento", que não deve ser estático, mas permanente, dialogando com a práxis da equipe e do próprio CEA;

3. Indicar a diversidade de Espaços organizados, localizados em diversas áreas (rurais, urbanas, naturais), novos ou adaptados, que podem ser do próprio CEA ou utilizados por ele no desenvolvimento de suas atividades.

4. Colocar a questão dos recursos ${ }^{15}$ e dos materiais que são necessários para o CEA desempenhar suas funções. Recursos e materiais que podem ser bastante variados e de diversas naturezas: pedagógicos, metodológicos, estruturais, logísticos, de divulgação, dentre outros.

5. Indicar uma dimensão consideravelmente relevante no que se refere à Estratégia Avaliativa. Esta foi ganhando importância na medida em que cresceu o debate conceitual sobre a temática na Espanha, embora já estivesse presente em obras consideradas, por lá, mais antigas. Já em 1992 Oscar Cid comenta sobre a necessidade de os CEAs terem "critérios, técnicas e momentos da avaliação do processo" (Cid, 1992, p.18).

Há, ainda, outros elementos que merecem ser considerados na busca por uma construção conceitual do termo CEA. Encontramos em mais de uma obra da Espanha outros ingredientes que contribuem com este debate.

\footnotetext{
${ }_{15}$ É importante ressaltar que há uma discussão na Espanha que procura diferenciar o conceito de Recursos para a EA e Equipamentos (aqui Centros) de Educação Ambiental. Pazos nos ajuda a diferenciar um termo do outro, ao afirma que: "O equipamento é por sua vez o maior dinamizador e promotor de outros recursos para a educação ambiental" (2001, p.7).
} 
'Provavelmente (o CEA) seja o recurso mais complexo, completo e singular que tem a educação ambiental, capaz de fomentar modelos de intervenção diferentes e formas de aprendizagem distintas das que acontecem em outros âmbitos educativos, e por isso é necessários reconhecer-lhe identidade própria $^{16 "}$ (Pazos, 2001, p.11).

Com este fragmento queremos trazer mais um elemento, que é relativo à necessidade de se perceber e encarar a temática dos CEAs como um movimento que tem identidade própria e características específicas. Enquanto na Espanha verifica-se que as iniciativas de CEAs constituem o que se tem chamado por lá como,

"O movimento dos Equipamentos de Educação Ambiental, um jovem e vigoroso movimento pedagógico assentado nos subúrbios dos sistemas educativos $^{17}$, que se vem disseminando por toda geografia do país ao longo da década de oitenta e de noventa, como resposta em boa medida a um processo de perda da formalização e da desmistificação do trabalho acadêmico, e em parte, como estratégia beligerante de uma educação renovada, crítica com seu entorno e comprometida com as problemáticas ambientais. Este movimento tem sido estimulado em uns casos pela iniciativa privada (...) e em outros (...) pela administração pública (...)" (Pérez, 1994, p.35).

A idéia de um movimento (ou de vários) representa para este debate, no Brasil, um terreno bastante incerto. Afirmar que, aqui, também dispomos de um movimento, com estas e aquelas características e atores principais, é consideravelmente ousado e perigoso. Não há elementos que possibilitem dar o devido embasamento para um debate mais qualificado sobre esta questão, o que não inviabiliza a possibilidade e a legitimidade de se propô-lo. Aliás, percebe-se uma necessidade premente de fazê-lo.

No próximo item, "Histórico dos CEAs no Brasil", esta discussão será retomada à luz dos dados levantados por este trabalho e do diálogo estabelecido com a literatura brasileira da educação ambiental e do movimento ambientalista.

\footnotetext{
${ }^{16}$ Grifo nosso.

17 Grifo nosso.
} 
Buscando, enfim, construir reflexões de natureza conceitual sobre a temática dos Centros de Educação Ambiental que dialoguem com todo o referencial até então apresentado, partimos para considerações voltadas diretamente sobre a temática em nosso país.

Esquematicamente, propomos uma concepção de Centros de Educação Ambiental (CEAs) que trata de sintetizar a essência destas iniciativas e pode ser visualizada na Figura 1 a seguir.

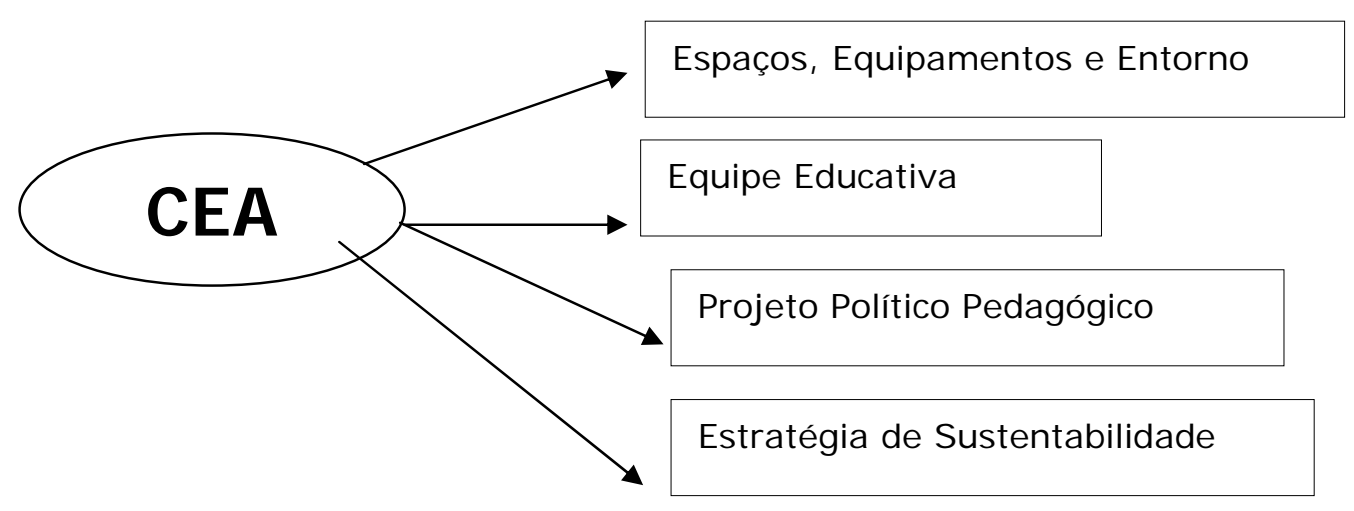

Figura 1- Dimensões relativas à concepção de CEA adotada

Estas quatro dimensões podem ser encaradas como sendo a essência de qualquer projeto ou iniciativa que se proponha constituir-se um Centro de Educação Ambiental (CEA).

A primeira delas (espaços, equipamentos e entorno) aponta para a necessidade de estruturas que, em geral possuem como "carro-chefe" uma edificação-sede dotada de salas de diversos formatos e funções (para oficinas, para reuniões, para exposições, multiuso, etc), auditórios, bibliotecas, cozinhas, e muitos outros. Esta dimensão também indica para a disponibilidade de equipamentos (retroprojetores, projetores de slides, computadores, maquetes, jogos pedagógicos, binóculos, etc) e para o potencial do entorno deste CEA (presença de cachoeiras, montanhas, remanescentes florestais nativos ou plantados, áreas rurais, monumentos arquitetônicos e históricos, cidades, vilas, bairros, áreas industriais, etc). Com relação ao entorno, entendemos que CEAs não devem, necessariamente, estar localizados em 
áreas naturais ou próximo delas (como unidades de conservação, parques, pequenas propriedades rurais), mas que podem ser projetados também em áreas degradadas, marginalizadas e abandonadas, sejam rurais ou urbanas (como favelas, áreas de exploração mineral, patrimônios histórico-culturais e outras). O fato de um CEA estar localizado distante de uma área natural não reduz seu potencial de ação, desde que se perceba seu entorno como um espaço rico, do ponto de vista pedagógico, e "vivo", do ponto de vista socioambiental.

A segunda dimensão aborda a questão da Equipe Educativa. Quando se quer planejar um CEA é preciso projetar seus espaços e seus equipamentos e mapear seu entorno, mas, também, discutir a questão de "pessoal". Com quantas pessoas contaremos para o funcionamento do CEA no dia a dia? Pessoas com quais formações, habilidades e experiências consideramos importantes para viabilizar a proposta do CEA? Achamos relevante compor uma equipe multidisciplinar que atue de forma inter e transdisciplinar ${ }^{18}$ para atuar no CEA? Consideramos importante a presença de trabalho voluntário no CEA? Haverá suficiente autonomia da equipe para resolver situações-problema do dia a dia? Faz-se necessária a presença de um chefe, um coordenador da equipe?

A terceira dimensão é a do Projeto Político-Pedagógico. Trata-se de uma dimensão que merece ser melhor discutida em virtude de uma compreensão restrita que se verifica junto aos CEAs de modo geral no país. Entendemos por Projeto Político-Pedagógico (PPP) não somente um documento que agrupa uma série de planejamentos e de elementos relativos ao CEA (seu funcionamento, sua organização, sua missão), mas como sendo algo mais profundo que um documento norteador do CEA. Encaramos como um processo de permanente construção de tais questões que deve envolver todos os membros da equipe e todos os atores e atrizes sociais com os quais o CEA dialoga e se relaciona.

É preciso decodificar cada um das letras "Pês" presentes no termo Projeto Político Pedagógico. A primeira decorre do ato de se projetar e planejar alguma ação ou um conjunto de ações, característica básica do PPP. A segunda aponta para a dimensão política que o CEA deve cumprir e encontra importante substrato em autores do campo educacional (como Paulo Freire), do ambientalismo e da educação ambiental (como Isabel Carvalho e Marcos Sorrentino), além de documentos de

\footnotetext{
${ }^{18}$ Dialogando com o que propõe Nicolescu (1999), quando procura elucidar as diferenças entre os termos Multi, Inter e Transdisciplinar, que muitos consideram sinônimos.
} 
referência da EA brasileira (como o Tratado de EA para Sociedades Sustentáveis e Responsabilidade Global). Há uma intencionalidade política, de caráter não partidário, potencialmente presente na atuação de CEAs e que deve ser considerada para ser devidamente trabalhada na proposta do CEA. Considerando que CEAs têm um papel fundamental que é o de auxiliar no processo de formação de cidadãos, remetemos o termo "intencionalidade política" à questão: "formar indivíduos para qual tipo de sociedade?". Com esta questão queremos assumir uma característica fundamental da educação ambiental, que é a sua não neutralidade diante dos acontecimentos e das realidades socioambientais cotidianas. Trata-se de uma questão chave que deve nortear o processo de construção de projetos político pedagógicos de CEAs no país. Por fim, o terceiro "P", o pedagógico, remete-nos para um processo de decodificação da intencionalidade do CEA na formação de cidadãos "sócioambientalmente educados". Obviamente, trata-se de uma expressão que carrega muitos jargões conceituais, mas com ela, apontamos para a dimensão propriamente educacional do CEA, e de que forma ela é concebida e abordada pela sua equipe (em termos de temas e conteúdos, procedimentos metodológicos, tipo de atividades, interações equipe-público, formas de avaliação do CEA e das atividades, etc).

A questão chave da dimensão do Projeto Político-Pedagógico (PPP) reside no fato de que muitos CEAs têm sido criados e até mesmo inaugurados sem qualquer planejamento anterior. Trata-se de um ponto preocupante, uma vez que há muitas iniciativas de CEAs no país sendo implementadas sem a mínima discussão de questões básicas como:

1) Qual a concepção que se tem de CEA? Parte-se de quais referenciais teóricos, práticos e com quais experiências?

2) O que se objetiva alcançar com este CEA? Para onde se pretende caminhar? A quem se destina este CEA?

3) Quais os princípios que irão nortear a proposta?

4) Com quais recursos, pessoas e condições dispõem-se para tal?

5) Quais as estratégias para avaliar esse processo? Quais serão os avaliadores?

Apresentamos, por fim, a quarta dimensão da proposta conceitual esquemática, que é a da Estratégia de Sustentabilidade. É possível que seja a mais complexa de todas, porque se relaciona com campos diversos do conhecimento, como o 
conceitual $^{19}$ e com áreas dos campos da administração (planejamento, gestão), social e político. Não adianta o CEA ter todas as três dimensões bem equacionadas e não estar munido de um Plano que explicite quais estratégias ele vai adotar para alcançar a meta da sustentabilidade, englobando todas as suas dimensões: ecológica, econômica, social, política e cultural. Todo este conjunto de estratégias está diretamente relacionado com práxis do planejamento e da avaliação.

A proposta conceitual esquemática de CEA não tem um caráter reducionista. Com ela não se pretende simplificar ou menosprezar a natureza polissêmica do termo, mas sim tentar apresentá-lo de uma forma mais pedagógica.

De fato, a partir do levantamento realizado por este estudo com 101 CEAs de todo o país, verificou-se que embora tenham essas dimensões em comum que os permitem ser considerados como tais, eles constituem iniciativas que guardam entre si muitas especificidades. A partir desta observação, podemos retomar a idéia do "movimento dos CEAs brasileiros" como um fenômeno singular e plural, pois ao mesmo tempo em que representa uma pluralidade de iniciativas, as mais diversas possíveis, conserva e valoriza em cada uma delas as suas potencialidades e peculiaridades. Dessa forma, vislumbramos que se trata de um movimento que dialoga com a diversidade, sem a pretensão de homogeneizar as iniciativas para um padrão de CEA (que, por sinal, estamos vendo que não existe).

Há, ainda, algumas características que merecem ser elucidadas com relação à temática dos CEAs.

Se há considerável complexidade nas suas dimensões essenciais, há também uma grande variedade de denominações e nomenclaturas relativas ao que estamos chamando aqui de CEA, a começar por Centros (de Meio Ambiente, de Estudos Ambientais, de Referência em EA, de Referência Ambiental, de Pesquisas Ambientais, de Visitantes, de Interpretação Ambiental, de Informação e Formação Ambiental, de Informação Ambiental, etc); passando por Núcleos (de Meio Ambiente, de Educação Ambiental, Interdisciplinar de Meio Ambiente, Ambiental, etc); e também por outras muitas denominações, como: Casas (de EA, da Natureza, do Meio Ambiente, da Ecologia, etc), Escolas (da Natureza, do Meio Ambiente, de Educação Ambiental, etc) e Fazendas, Sítios, Chácaras, etc.

\footnotetext{
${ }^{19}$ Que por sua vez, dialoga com outras áreas do conhecimento, e lembrando que há muitas concepções sobre o termo sustentabilidade e seus decorrentes, como Desenvolvimento Sustentável e Sociedades Sustentáveis.
} 
Cada uma dessas iniciativas pode ser promovida e gerida, no Brasil, por uma diversidade de instituições, dentre as quais podemos mencionar: os órgãos públicos (municipais, estaduais e federais), as ONGs, as empresas, as universidades, as fundações (todas estas públicas e privadas), as associações, além de parcerias entre estas instituições o que têm gerado CEAs de caráter misto.

Cabe aqui enunciar dois termos bastante recorrentes que são os de instituição promotora e instituição gestora. A primeira refere-se àquela que patrocina o CEA, através de dotações financeiras e orçamentárias específicas e, em geral, é a responsável pelo "toque inicial" da proposta. A segunda (gestora) é aquela que promove o funcionamento do CEA cotidianamente, desenvolve e coordena as atividades e tem a atribuição de geri-lo como um todo. Em geral, os CEAs apresentam a mesma instituição para ambas funções (as de promoção e gestão), mas há também CEAs onde distintas instituições se encarregam destas atribuições. Por exemplo, uma empresa implementa uma proposta de CEA mas concede sua gestão a terceiros (que pode ser uma outra empresa, uma associação, uma ONG, etc, ligada ao campo da educação ambiental). Estas duas atribuições distintas ajudam a conferir maior complexidade à temática dos CEAs, criando diversos tipos de relações entre instituições promotoras e gestoras.

Como visto, a construção de uma proposta conceitual do termo Centro de Educação Ambiental requer o inter-relacionamento entre diversas áreas do conhecimento, diversas experiências e saberes, além de uma boa dose de ousadia. $\mathrm{O}$ ato de pesquisar requer (re)criação e exige um intenso processo de (des)construção. Sabemos que o campo da Educação Ambiental atravessa a sua "juventude" no Brasil. Na atualidade, é também perceptível todo o acúmulo construído nos campos teóricoconceitual, metodológico e prático (o das ações, intervenções, projetos, programas e porque não Centros de Educação Ambiental). Se há um certo avanço no campo das ações práticas disponíveis na EA brasileira, há considerável carência (mesmo ausência) de referenciais teóricos em algumas "frentes" deste leque de iniciativas. Sem dúvida, este é o panorama que nos deparamos "frente" aos CEAs. Toda e qualquer proposição e contribuição que este estudo pretende deixar, deve ser encarada como sendo parte de um processo de construção, que não se propõe a trazer "respostas absolutas e definitivas", mas sim provocar discussões com interlocutores - educadores ambientais - partindo de algum referencial que, minimamente, nos forneça algum alicerce conceitual mais sólido. 
Considerando, também, que no Brasil dispomos de diversas educações ambientais pensadas e praticadas, as múltiplas iniciativas de CEAs em atividade no país constituem um cenário consideravelmente complexo e biodiversificado de experiências, ações, articulações, intervenções, mobilizações, idealizações, revestidas de um potencial fabuloso de constituição de espaços que contribuam para a construção de sociedades sustentáveis.

\subsubsection{Histórico dos Centros de Educação Ambiental no Brasil}

Embora pareçam constituir-se iniciativas de caráter bastante recente no país, os Centros de Educação Ambiental (CEAs) iniciam sua trajetória a partir de meados da década de 70, sobretudo por intermédio de esforços demandados pelo setor público. As iniciativas "pioneiras" de CEAs emergem a partir dessa época, ainda bastante tímidas e pontuais. Respectivamente nos anos de 1976 e 1978, emergem no país dois $\mathrm{CEAs}^{20}$, o primeiro numa Unidade de Conservação de São Paulo (Núcleo Perequê ${ }^{21}$, situado no Parque Estadual da llha do Cardoso) e o outro ligado à Universidade Federal do Rio Grande do Sul (Centro de Estudos Costeiros, Limnológicos e Marinhos - CECLIMAR). A partir dos dados levantados por esta pesquisa, é possível considerar tais iniciativas como sendo as "pioneiras" no Brasil.

Cabe salientar que, embora este estudo tenha adotado estas duas iniciativas como sendo as "pioneiras" no país, novas pesquisas e trabalhos voltados para uma análise mais aprofundada sobre esta questão histórica dos CEAs certamente poderão trazer novos elementos e subsídios dando mais segurança nestas datas e períodos. É possível encontrar iniciativas bastante anteriores a estas, de Jardim Botânicos, Museus e de Parques, que buscavam propiciar momentos de interação dos seres humanos com elementos da natureza, sem qualquer menção à Educação Ambiental, muito menos a Centros de Educação Ambiental. Como o foco deste estudo era o de mapear e identificar os momentos e iniciativas "pioneiras" de CEAs no país, adotou-se como critério a consideração daquelas que se consideravam como tal, mesmo que não se denominassem como tal.

\footnotetext{
${ }^{20}$ Nessa época tais iniciativas não se denominavam nem se concebiam como tal, embora tivessem um enfoque bastante direcionado para trabalhar a temática ambiental, sobretudo através de disponibilização de informações e do desenvolvimento de pesquisas.

${ }^{21} \mathrm{Na}$ época denominado como Centro de Pesquisa Aplicada aos Recursos Naturais da llha do Cardoso CEPARNIC.
} 
Adotando então como base o estudo de Viola (1992) e buscando dialogar com diversas outras obras, fatos e acontecimentos do movimento ambientalista e da educação ambiental, criamos um quadro com as fases de emergência e de consolidação dos CEAs brasileiros. Viola (1992) propõe que o histórico do movimento ambientalista no Brasil pode ser compreendido em duas fases distintas, quais sejam: a primeira, chamada de Fase Fundacional, compreendida entre o período 1971-1986 e caracterizada, principalmente, pela denúncia e criação de consciência pública sobre os problemas de deterioração sócioambiental; e a segunda, chamada de Fase Recente (1988-1991), marcada pela ação multissetorial, pelo processo de institucionalização dos grupos ambientalistas e pelos esforços em articular a problemática da proteção ambiental com a do desenvolvimento econômico.

A partir das contribuições de Viola e dialogando com os dados levantados neste estudo $^{22}$, elaboramos um quadro das fases desta "história" (de surgimento e de consolidação) dos CEAs no Brasil.

Tabela 1. Fases de surgimento dos CEAs no Brasil

\begin{tabular}{lc}
\hline \multicolumn{1}{c}{ Nome da Fase } & Período (Anos) \\
\hline Fase Fundacional & $1976-1987$ \\
Fase da "Oficialização" & $1988-1992$ \\
Fase da Efetivação & $1993-1997$ \\
Fase Atual & $1998-2003$ \\
\hline
\end{tabular}

Abordaremos cada uma das fases buscando contextualizar as datas que as situam e os acontecimentos do movimento ambientalista e da educação ambiental brasileira da época, identificando e apresentando suas principais características, em especial àquelas que fazem referência à temática dos Centros de Educação Ambiental.

Os dados levantados pela presente pesquisa permitem identificar os momentos de emergência dos 101 CEAs que remeteram informações. Pode-se verificar na Figura 2 as porcentagens relativas de CEAs que foram surgindo em cada uma das quatro fases propostas.

\footnotetext{
${ }^{22}$ Foram obtidos dados de 101 CEAs de todas as regiões do país. No item "Uma panorâmica dos CEAs no Brasil" os resultados deste levantamento serão apresentados e discutidos.
} 


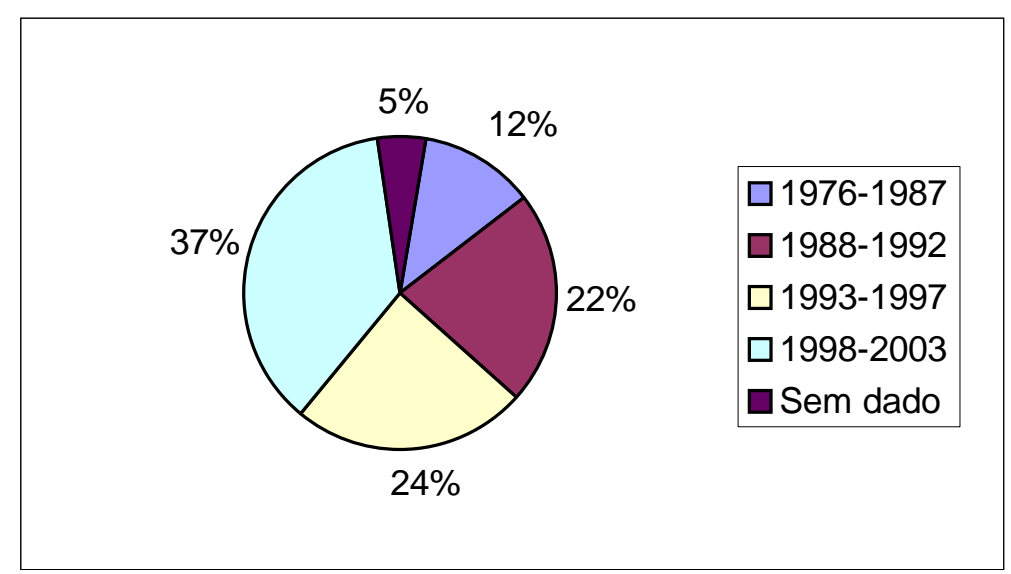

Figura 2 - Fases de surgimento dos CEAs no Brasil

É possível observar na Figura 2 que a Fase Atual (1998-2003) é aquela que concentra a maior parte (37\%) do surgimento de CEAs, acompanhada pela Fase anterior (da Efetivação, 1993-1997) com 24\% e pela Fase da "Oficialização" (19881993) com 22\%. Nota-se na Fase Fundacional (1976-1987) uma porcentagem de $12 \%$ de CEAs que surgem, sendo que $5 \%$ dos CEAs não responderam a esta questão (Anexo A, Questionário 1, questão 1.2).

\subsubsection{Antecedentes}

O ambientalismo no Brasil não é um movimento novo. Segundo Pádua (1997), o ambientalismo brasileiro teve sua origem entre 1820 e 1920 quando se caracterizou por possuir uma clara preocupação política. Este autor sustenta a tese de que o ambientalismo surge inicialmente em determinados países do chamado mundo "em desenvolvimento" em contraposição à tese internacional dominante de que o ambientalismo teria surgido, inicialmente, nos chamados países desenvolvidos.

"O ambientalismo surgiu no Caribe, na Índia, na África do Sul, na Austrália, na América Latina. Nasceu onde estavam sendo implantadas práticas de exploração colonial massivas e predatórias. Esta primeira descoberta é interessante na medida em que permite reformular o mito, o lugar-comum segundo o qual o ambientalismo é preocupação básica do Primeiro Mundo, e dele emergiu em direção à periferia. Ao contrário, a questão 
ambientalista transferiu-se da periferia para o centro, das áreas tropicais coloniais para os Estados Unidos e a Europa Ocidental" (Pádua, 1997, p.14).

Tais considerações apontadas pelo autor encontram certa convergência com a tese construída por Gaudiano (1998) relativa à estruturação do campo da Educação Ambiental, seu centro e suas margens (ou periferia), conforme vemos a seguir:

"No centro da educação ambiental convencional ou clássica (...) se encontra a conservação da natureza (...), nas margens (periferia) do campo, começam cada vez mais a cobrar visibilidade política e a reclamar seu próprio espaço (...). Isso não implica que a conservação da natureza deixe de ser um objetivo capital da constituição do campo. O que se tem provocado é uma recolocação do conceito à luz de elementos que haviam sido excluídos: os fins e as estratégias de conservação sob condições de pobreza e no marco de padrões socioculturais e interesses políticos diferentes aos dos países “centrais"' (Gaudiano, 1998, p.72).

No entanto, com relação ao período de origem do ambientalismo no Brasil, verifica-se certas divergências na literatura. Enquanto Pádua (1997) sustenta a tese de que o campo ambiental no país já inicia sua atividade no início do século XIX (por volta de 1820), outros autores (Carvalho, 2001 e Cascino, 1998) apontam para a emergência do ambientalismo somente a partir do fim da década de 60 e início dos anos 70. Sorrentino (1993, p.9) denomina-o como um "novo movimento social, relacionado às questões ambientais e ecológicas".

"É na convergência de todos esses pontos, os quais faço questão de repetir, que surge o ambientalismo: o movimento hippie, o rock-and-roll, a liberação sexual e as drogas, o feminismo, os movimentos dos negros e homossexuais, a luta "por um planeta mais azul", antinuclear e pacifista, o nascimento da multimidiatização, a proliferação da informação, da TV, e mais recentemente, nos anos 90, a informática" (Cascino, 1998, p.34). 
Assim complementa Carvalho, interligando o surgimento do ambientalismo e da educação ambiental:

"O surgimento de um campo ambiental no Brasil (...) está relacionado aos anos 70. A EA por sua vez é um fenômeno que começa a ganhar visibilidade na década seguinte. É apenas a partir dos anos 80 que começa a configurar-se um espaço próprio dessa prática educativa. Desse modo, se o campo ambiental nasce nos nossos anos de chumbo, a EA cresce nos anos da abertura política e da ascensão dos novos movimentos sociais. Ainda que de forma dispersa, é a partir dessa década que, no Brasil, alguns educadores passam a se chamar ambientais (Carvalho, 2001, p.146).

De fato, há importantes antecedentes de atividades ligadas à temática ecológico-ambiental que emergem desde o final do século XIX e início do XX, especialmente as intervenções conhecidas como estudos do meio.

A natureza e o meio como recursos educativos já eram mencionados por antepassados ilustres como Rousseau (1712-1778) e Freinet (1896-1966) e diversas correntes pedagógicas têm insistido, ao longo do tempo, sobre a necessidade de recorrer à experiência e ao estudo do meio como estratégia de aprendizagem e de preparação do indivíduo para a vida - o meio como fonte educativa (Sorrentino, 1993, p.7).

Muito antes de se falar em educação ambiental, ela já era praticada, ao menos parcialmente, através de algumas iniciativas de professores criativos, em vários pontos do país (Czapski, 1998, p.35).

De fato, verifica-se o registro de diversas atividades relacionadas à temática ecológico-ambiental no Brasil, a partir da década de 50. Tais intervenções filiam-se numa vertente eminentemente conservacionista, na qual conservar a natureza era o que interessava. É possível constatarmos a emergência de atividades realizadas por professores, museus, e algumas entidades, ainda bastante incipientes nessa época. Cabe ressaltar a necessidade de visualizarmos a participação do setor público governamental neste cenário, sobretudo na implantação de Unidades de Conservação, em especial os denominados Parques Nacionais (instituídas pelo poder público 
federal), e os Parques Estaduais e Municipais (instituídos pelos poderes públicos nos âmbitos estadual e municipal, respectivamente).

Esta participação guarda considerável relação com 0 processo de desenvolvimento vivenciado pelo Brasil desde o início do século XX.

"Ao se analisar a implantação do sistema brasileiro de unidades de conservação, nota-se que a época de criação e a sua distribuição geográfica estão intimamente ligadas a diferentes etapas do processo de desenvolvimento do País. Em geral, a criação de Parques Nacionais ou outras áreas protegidas, precede ou coincide o avanço de frentes pioneiras sobre regiões virgens. Desta forma, o desenvolvimento estaria impulsionando a criação de áreas naturais protegidas. Contraditoriamente, este mesmo desenvolvimento ameaça a existência das áreas protegidas já estabelecidas (Quintão, 1983, p.13).

É sobre esse pano de fundo que emergem as primeiras iniciativas de Centros de Educação Ambiental (CEAs) no Brasil. Os primeiros CEAs começaram a ser implementados a partir de meados da década de 1970. É possível encontrar relevante associação com o que nos concede a literatura relativa ao ambientalismo e à educação ambiental. Assim, a partir das fases apontadas por Viola (1992) é possível propor quatro fase ${ }^{23}$ que configuram o histórico dos CEAs no Brasil. Trata-se de uma tentativa de identificar os acontecimentos e fatos que influenciaram sobremaneira a emergência, o fomento, a sustentação e a consolidação desse movimento complexo, que arriscamos chamá-lo como movimento dos centros de educação ambiental no Brasil.

Retomando as quatro fases propostas (Fase Fundacional: 1976-1987; Fase da "Oficialização": 1988-1992; Fase da Efetivação: 1993-1997; e Fase Atual: 1998 2003), trataremos cada uma delas separadamente, buscando apontar e identificar a relevância das datas que demarcam cada fase e realizar uma breve caracterização de cada uma.

\section{A - Fase Fundacional (1976 - 1987)}

\footnotetext{
${ }^{23}$ Apresentadas na Tabela 1.
} 
Faz-se necessário apresentar os porquês da escolha deste período para demarcar esta fase. A partir dos dados levantados nesta pesquisa ${ }^{24}$, verificamos que a primeira iniciativa de Centro de Educação Ambiental data de 1976, sendo a de criação do Núcleo Perequê (situado no Parque Estadual da Ilha do Cardoso - SP). Antes desta data não há, pelos dados levantados, outra iniciativa mais antiga e não foi encontrada qualquer menção na literatura. O outro ano (1987) remete-nos ao parecer $226 / 87^{25}$, de 11 de março, do MEC, o qual podemos considerar como sendo o primeiro documento "oficial" do governo brasileiro que faz menção a CEAs. Cabe salientar que há outros fatos do campo da EA e do ambientalismo que marcaram estas datas, mas nos atentaremos somente aos acontecimentos mais diretamente relacionados com a história dos CEAs no Brasil.

Retomando o parecer 226/87 do MEC, este, além de referendar a necessidade de se implementar a educação ambiental de maneira interdisciplinar, propõe como uma das sugestões gerais a "Formação de uma equipe interdisciplinar e de um Centro de Educação Ambiental em cada unidade da Federação" (Dias, 1998, p.334).

Tais CEAs deveriam atuar como pólos irradiadores de ações no campo da EA. Embora já mencionados (e concebida significante importância à sua existência), os CEAs viriam a ser "oficialmente" alavancados a partir dos preparativos da ECO - 92. De fato, a segunda fase aqui proposta (Fase da "Oficialização") tem essa denominação porque é a partir do final dos anos 80 , sobretudo pela agitação política em torno da nova Constituição, dos desdobramentos decorrentes deste parecer do MEC e do processo de articulação para a realização da Conferência sobre Meio Ambiente e Desenvolvimento no Brasil (a ECO - 92), que os Centros de Educação Ambiental passam a ser considerados "oficialmente" como sendo instrumentos de ação e de implementação da EA no país.

O que se observa na fase fundacional (1976 - 1987), no âmbito do ambientalismo e da educação ambiental, é um movimento ainda restrito a determinados cenários e contextos, sobretudo com o intuito de denúncia de problemas relacionados à degradação ambiental, conforme afirma Viola (1992):

"Na segunda metade da década de 1970 surgem alguns grupos ambientalistas nas principais cidades do Sul-Sudeste. Trata-se de grupos

\footnotetext{
${ }^{24}$ De 101 Centros de Educação Ambiental do país.

${ }^{25}$ O conteúdo deste documento pode ser encontrado nos anexos do livro "Educação Ambiental: princípios e práticas", de Genebaldo Freire Dias (1998).
} 
pequenos de ativistas que contam com um pobre apoio financeiro de uma periferia de simpatizantes e que tem como objetivo denunciar os principais problemas de degradação ambiental nas cidades (...) A denúncia, muitas vezes radical, da degradação ambiental foi o motor implícito ou explícito do ambientalismo brasileiro durante toda fase fundacional. As organizações profissionais não têm como objetivo principal a denúncia. Elas têm como objetivo central à afirmação de uma alternativa viável de conservação ou restauração do ambiente modificado" (Viola, 1992, p.55-63).

Há certo consenso na literatura ao considerar que "o começo do movimento ambientalista no Brasil foi conservacionista" (Carvalho, 2001, p.80). E os seus antecedentes podem ser deslocados para a década de 50, ou antes, quando surgiram associações de proteção aos animais, como a Fundação Brasileira para Conservação da Natureza (FBCN), dentre outras.

Durante a fase fundacional dominou no ambientalismo brasileiro uma definição estreita da problemática ambiental que o restringiu, basicamente, a combater a poluição e a apoiar a preservação de ecossistemas naturais (Viola 1992, p.59). Já nos anos 70 temos diversos exemplos de associações ambientalistas lutando por liberdades democráticas e direitos humanos básicos como áreas verdes, arborização urbana e outras causas.

Diversos são os movimentos sociais que configuram essa fase de fundação do ambientalismo no Brasil, dentre eles: o movimento contra a construção do novo aeroporto em Caucaia Alto (1977), o movimento de defesa da Amazônia, localizado no Sudeste do país; o movimento contra a construção das usinas nucleares gerando diversas mobilizações antinucleares no Rio e em São Paulo; o movimento contra a extrema deterioração sócioambiental em Cubatão; o movimento contra os agrotóxicos, mais ligado à atuação da Associação Gaúcha de Proteção ao Ambiente Natural (AGAPAN), sobretudo na região Sul do país (Viola, 1992).

Diversos são os acontecimentos do ambientalismo que marcaram essa fase e "na primeira metade da década de 1980 há uma proliferação de grupos ambientalistas nas regiões Sul e Sudeste" (Viola, p.57).

"A proliferação de grupos ambientalistas na primeira metade da década de 1980 pode ser explicada em boa medida pela emergência de valores pós- 
materialistas num setor (particularmente a juventude) da classe média educada" (Viola, 1992, p.58).

Em especial podemos destacar dois movimentos paralelos que obtiveram considerável destaque no seio dos diversos movimentos relacionados ao ambientalismo nesta fase: os de denúncia da degradação ambiental nas cidades e as comunidades alternativas rurais (Viola, 1987).

É possível construir a partir da afirmação de Viola (1987) a tese de que os primeiros Centros de Educação Ambiental (CEAs) não emergem nem numa perspectiva de denúncia da degradação ambiental, nem junto a estas comunidades rurais alternativas. Os CEAs considerados "pioneiros ${ }^{26 "}$ emergem do impulso do setor governamental nos âmbito federal (UFRGS), estadual (Instituto Florestal - Parque Estadual - SP) e municipal (Zoológico Municipal de Sorocaba) estando sintonizados com uma perspectiva conservacionista, conforme colocado por Carvalho (2001) acerca do início do ambientalismo no Brasil.

Sobretudo a partir do início e meados dos anos 80 verifica-se a emergência de CEAs mais sintonizados na perspectiva apontada por Viola (1987). Surgem iniciativas ligadas a organizações ambientalistas de denúncia de impactos ambientais, tanto no meio urbano do Sul-Sudeste, mas também organizações ligadas às comunidades alternativas rurais. Ao menos quatro iniciativas de CEAs emergem sintonizadas a esta última perspectiva: o Centro de Apoio ao Pequeno Agricultor - CAPA (Ipê - RS, 1982), o Centro Estadual Integrado de Educação Rural de Boa Esperança (Boa Esperança ES, 1982), o Sitio Duas Cachoeiras (Amparo - SP, 1985) e o Jardim das Florestas da Associação de Preservação do Meio Ambiente do Vale do Itajaí - APREMAVI (Atlanta - SC, 1987).

São CEAs que estão sintonizados com a temática da agroecologia, da agricultura ecológica e familiar e que emergem com uma proposta de atuar na interface entre estas temáticas e a da educação ambiental. Todas estas iniciativas surgem em áreas rurais de pequenos municípios do interior do Brasil.

\footnotetext{
${ }^{26}$ Aqui considerados como sendo: o Núcleo Perequê do Parque Estadual da llha do Cardoso - SP (1976) e o Centro de Estudos Costeiros, Limnológicos e Marinhos - CECLIMAR da UFRGS - RS (1978), em alusão aos dados dos 101 CEAs levantados. Também se inclui como sendo uma iniciativa "pioneira" o Zoológico Municipal "Quinzinho de Barros", de Sorocaba, o qual, apesar de inaugurado em 1968, inicia eu programa educativo em 1979. Para mais detalhes sobre o Zôo de Sorocaba, consulte Mergulhão, 1998.
} 
No entanto, também há a emergência de CEAs (em menor escala) situados em cidades do Sul-Sudeste, conforme aponta Viola $(1987,1992)$. Merece destaque o CEA do Parque Ecológico do Tietê, criado em 1984, com enfoque conservacionista (sensibilização e interpretação).

Algumas características gerais podem ser apontadas nesta Fase Fundacional (1976 - 1987) de surgimento dos CEAs no Brasil. Como visto, podemos identificar, ao menos dois momentos distintos no interior desta fase, sendo um primeiro que vai de 1976 ao fim da década, caracterizado pela emergência das iniciativas "pioneiras" de CEAs, sob responsabilidade do setor público (federal, estadual e municipal) e com um marcante enfoque conservacionista; e um segundo momento que vai do início dos anos 80 até 1987, marcado pelo surgimento de CEAs ainda sintonizados com esta vertente, mas também emergindo iniciativas na linha do que Viola (1987) denominou como "comunidades alternativas rurais".

Apesar de ser possível situar dois momentos distintos dentro desta fase, é possível tecer algumas considerações gerais sobre as iniciativas que emergem nesta época. São em geral, como visto, CEAs dispersos e pontuais com considerável "filiação" à corrente conservacionista e com um referencial teórico-conceitual difuso norteando as concepções destas iniciativas. Tal processo somente passa a ocorrer no final desta fase fundacional, mais precisamente a partir do decreto 226/87 do MEC, de 11 de março de 1987, que faz menção à necessidade de criação de CEAs no país. Pode-se considerar que este seja o primeiro documento oficial que faz menção aos CEAs no país. Como veremos na próxima fase, o discurso "oficial" (sobretudo do MEC) que emerge a partir de tal decreto (e é complementado por outros documentos e acontecimentos) traz uma concepção de CEA que apresenta estreita ligação com o ensino formal.

\section{B - Fase da "Oficialização" (1988 - 1992)}

Esta fase inicia-se a partir dos desdobramentos do parecer 226/87 do MEC, do processo de construção da nova Constituição Brasileira e das constituintes estaduais estendendo-se até o final de 1992 quando se realizou, em Foz do Iguaçu - PR, o I Encontro Nacional de Centros de Educação Ambiental, promovido pelo MEC, ainda como um dos diversos desdobramentos da ECO - 92. 
Nesta fase, verifica-se que o termo CEA passa a ser incorporado pelo setor público (sobretudo pelos Ministérios da Educação (MEC) e do Meio Ambiente (MMA) e pelo IBAMA) por meio de algumas ações, publicações, documentos, pronunciamentos.

Como se pode verificar a partir da leitura e análise de alguns documentos oficiais que fazem menção aos CEAs, há algumas contradições no que diz respeito à questão conceitual destas iniciativas. O parecer 226/87 do MEC, embora não faça qualquer menção à concepção dos CEAs que se propõe a criar, já nos fornece algumas pistas que apontam a direção desta proposta conceitual "oficial" de CEAs, marcadamente ancorada no bojo da educação formal. Segundo este documento há um

"grau incipiente de uma consciência ecológica no país (...) e que o reforço dessa consciência (...) passa obrigatoriamente pela escola de $1^{\circ}$ e $2^{\circ}$ graus, no desenvolvimento da educação formal (...) o processo educacional a ser desenvolvido através de escolarização regular tem que emergir de dentro da própria escola" (Dias, 1998, p.332-333).

De fato, o próprio MEC lança em 1991 um documento intitulado "Proposta para implantação de Centro de Educação Ambiental", no qual é possível identificarmos algumas questões que vem ao encontro ao apresentado na passagem anterior, com relação ao parecer 226/87.

"Em vista do que precede, e diante da importância da Educação Ambiental no âmbito maior da política do Governo Collor, o MEC programou a criação de escolas pedagógicas de ensino fundamental e médio identificadas como Centros de Educação Ambiental (...) Tais escolas, ou Centros de Educação Ambiental, terão os objetivos de ensinar e de incentivar a participação de toda a comunidade no processo de Educação do meio ambiente" (Brasil, 1991, p.8).

Partindo do exposto no trecho acima, verifica-se que a proposta inicial do MEC era a de promover a Educação Ambiental junto ao ensino fundamental e médio ${ }^{27}$, não

\footnotetext{
${ }^{27}$ Naquela época ainda denominados como $1^{\circ}$ e $2^{\circ}$ graus, respectivamente.
} 
a partir da criação de uma disciplina (argumento principal trazido pelo parecer 226/87), mas sim a partir da implementação de Centros de Educação Ambiental (CEAs) que iniciariam esse processo dentro da escola, com o intuito de atingir toda a comunidade. O CEA, sob esta ótica, constituiria-se num pólo irradiador de experiências que estariam sendo construídas dentro e a partir da própria escola.

Alguns questionamentos merecem ser feitos com base nesta perspectiva conceitual "oficial" de CEA. Trata-se de uma proposta que guarda estreita relação com o ensino formal (com a escola), tendo como substancial público-alvo estudantes do ensino fundamental e médio da rede de ensino. Esta concepção, em nenhum momento, faz menção ou demonstra considerar a existência de outras iniciativas de Centros de Educação Ambiental que se encontravam em atividade no país naquela época (final dos anos 80 e início dos 90). Desta forma, parece-nos ao menos questionável o fato de o MEC não ter buscado realizar qualquer levantamento ou mapeamento de iniciativas de CEAs em atividade no Brasil nesta época ou anterior à ela.

Há uma outra publicação do MEC que faz menção aos CEAs (e a criação de projetos pilotos) e tenta explicitar com mais detalhamento a proposta metodológica de criação destas iniciativas:

"Os centros de educação ambiental não seriam escolas pedagógicas, mas sim centros geradores ou captadores de idéias e propostas. Na semana passada implantamos o Centro de Educação Ambiental de Porto Seguro BA e teremos outros na região da mata atlântica, na mata amazônica, no cerrado e na floresta amazônica, que chamamos de projetos pilotos (...) a idéia dessa proposta pedagógica do Centro de Educação Ambiental seria utilizar o programa curricular oficial e transcender o banco escolar, quer dizer, envolver o saber popular e complementar com a proposta curricular. Envolvendo o saber popular e o saber científico, o Centro seria catalizador e difusor desses conhecimentos" (Brasil, 1992, p.102).

A partir da análise deste trecho é possível identificar mais dois elementos para serem discutidos. O primeiro refere-se a proposta de criação de CEAs a partir de experiências modelares, chamados de projetos pilotos de CEAs, e o segundo refere-se a uma característica presente na concepção "oficial" de CEA relativa ao seu papel de 
difusor de conhecimentos. Seria importante e oportuno, neste momento, retomar as duas considerações já enunciadas anteriormente (CEAs tendo como público-alvo preferencialmente estudantes e o fato de o MEC não fazer qualquer menção à existência de outras iniciativas de CEAs em atuação no país neste período) aliadas a estas duas outras considerações (sobre os projetos pilotos e sobre o papel difusor de informações dos CEAs) e buscar discuti-las a luz da concepção de CEA que este estudo constrói.

Parece central que, a partir da concepção dos CEAs como sendo uma "extensão da escola", estabeleçamos conexões importantes com ao menos duas das quatro considerações apontadas anteriormente. Quando a concepção "oficial" de CEAs remete à questão escolar isso acarreta automaticamente a consideração de duas das quatro questões apontadas:

a) direciona e delimita como segmento populacional (público-alvo) desta proposta aquelas pessoas diretamente relacionadas com o universo escolar, qual sejam, estudantes e professores basicamente. Cabe ressaltar que esta concepção aponta para a necessidade de se atingir toda a comunidade a partir das ações desenvolvidas na escola; e

b) apresenta uma tendência a um enfoque tradicional de Educação ${ }^{28}$ centrado na transmissão do conhecimento, o que Paulo Freire (2002) denomina como "Ensino bancário".

Em relação à questão do público-alvo dos CEAs é possível encontrar importantes elementos em trabalhos espanhóis do mesmo período ${ }^{29}$ (Jornada de Educación Ambiental, 1987 e Cid, 1992), os quais identificam, basicamente, que a grande maioria dos CEAs espanhóis atua preferencialmente junto ao público escolar e reforçam a necessidade de se diversificar tais segmentos populacionais.

"Neste momento $80 \%$ dos equipamentos existentes estão destinados ao público escolar (...) Há poucos recursos educativos destinados especificamente ao público adulto (...) Dentro da oferta específica ao mundo escolar deve haver uma maior atenção aos distintos níveis (de ensino)" (Jornadas de Educación Ambiental, 1987, p.57-58).

\footnotetext{
${ }^{28}$ Segundo a classificação proposta por Libâneo, 1987.

${ }^{29} \mathrm{Em}$ referência ao período que vai do final da fase fundacional ao final da fase de "oficialização" dos CEAs no Brasil, ou seja, de 1987 a 1992.
} 
Retornando aos documentos que de certa forma "oficializaram" os CEAs no Brasil, verifica-se que a implementação desta proposta foi quase que inteiramente direcionada para a questão dos projetos pilotos de CEAs. A partir destes projetos a proposta dos CEAs deveria ser viabilizada.

"Diante das situações específicas de agressão ao meio ambiente, propõese a criação de Centros de Educação Ambiental, como projetos-pilotos, a serem localizados, respectivamente na região da Mata Atlântica - (Porto Seguro/BA), no Pantanal e na Região da Floresta Amazônica" (Brasil, 1991, p.8).

Ao se analisar uma outra publicação do próprio MEC (Brasil, 1994, p.10) é possível verificar a proposição de seis projetos pilotos e as respectivas instituições que se responsabilizariam por implementar tais iniciativas:

- Porto Seguro - BA. Prefeitura Municipal de Porto Seguro.

- Manaus-AM. Universidade do Amazonas.

- Rio Grande-RS. Fundação Universidade do Rio Grande.

- Aquidauana-MS. Prefeitura Municipal de Aquidauana.

- Foz do Iguaçu-PR. Itaipu Binacional.

- Fernando de Noronha-PE. Distrito Estadual de Fernando de Noronha.

Pedrini (1997) complementa tais colocações do MEC e faz-nos uma provocação consideravelmente pertinente:

“(...) o MEC (1991) divulgou documento apresentando sua 'Política de EA: linhas de ação'. Esta centrava-se na instituição de Centros de Educação Ambiental (CEAs) em todas as regiões do Brasil. No próprio documento já mencionavam a instalação de oito CEAs em cidades distantes de megalópoles. O que fazem estes CEAs?" (Pedrini, 1997, p.42).

Quanto à situação atual destes projetos pilotos, não se encontrou na literatura disponível, inclusive no MEC, qualquer relato, estudo, documento, registro, relativo a eles. Num trabalho anterior (Silva, 2001a), verificamos que, dos 6 projetos pilotos, 
alguns nem saíram do papel, enquanto que os outros que estão em atividade, se mantiveram graças às instituições locais que as acolheram (universidade, distrito, empresa). Certamente vislumbra-se um campo importante de pesquisa e novos estudos, buscando refletir sobre as virtudes e as dificuldades desta proposta dos projetos pilotos que o MEC deflagrou sobretudo durante a primeira metade dos anos 90.

Há que se considerar ao menos mais dois acontecimentos de considerável relevância para a consolidação desta proposta "oficial" de CEAs no país. Os dois remetem-nos ao ano de 1992. O primeiro, no âmbito do IBAMA, que através da portaria $\mathrm{n}^{0} 77$ - N, de 13 de julho, cria os Núcleos de Educação Ambiental (NEAs) nas superintendências Estaduais do órgão. A portaria estabelece que:

"O Núcleo de Educação Ambiental tem por finalidade assegurar atividades de Educação Ambiental à defesa do meio ambiente(...) de forma a estimular a percepção regional dos problemas ambientais(...); (deve) apoiar programas e ações educativas orientadas para promover a participação da comunidade na preservação e conservação do meio ambiente(...), (deve) apoiar ações voltadas para introdução da Educação Ambiental em todos os níveis da educação formal e não formal" (Brasil, 1992).

Ressalta-se que há considerável ausência de trabalhos que objetivaram avaliar ou acompanhar a atuação dos NEAs, desde a sua criação até os dias atuais, bem como dos já mencionados projetos pilotos de CEAs. Constatamos, anteriormente, que "tais projetos pilotos nem sequer saíram do papel" (Silva, 2001, p.29). Encontramos também um questionamento com relação à atuação de alguns NEAs

"É desconhecido o suposto imenso trabalho realizado por alguns NEAs, como por exemplo, o da cidade do Rio de Janeiro" (Pedrini, 1997, p.47).

O outro acontecimento ocorrido também no ano de 1992 e que marcou esta fase de "Oficialização" dos CEAs no país refere-se ao I Encontro Nacional de Centros de Educação Ambiental, promovido pelo MEC em Foz do Iguaçu, entre os dias 7 e 9 de dezembro. Deste encontro surgiram diversas recomendações quanto ao Programa 
de CEAs a ser implementado pelo MEC, as quais fazem menção a questões como formação de recursos humanos para a realização de trabalhos interdisciplinares nos CEAs, necessidade de contextualização das atividades de cada CEA, relevância de se haver cooperação interinstitucional, dentre outras. Algumas delas são incumbências para o próprio MEC, dentre as quais podemos destacar que:

"O MEC deverá acompanhar, avaliar e orientar efetivamente os trabalhos dos Centros de Educação Ambiental que forem apoiados e reconhecidos por ele; o MEC deverá captar recursos para repasse aos Centros (...); o MEC deve promover mecanismos para trocas de informações entre os Centros através de reuniões periódicas, boletins e outros meios(...); o MEC centralizará uma rede de Centros de Educação Ambiental da qual deverão fazer parte outros Centros de Educação Ambiental, quer de instituições públicas ou privadas" (Dias, 1998, p.111-112).

Percebe-se a partir desta colocação que o MEC faz menção à existência e atuação de "outros" CEAs que não sejam os projetos pilotos nem aqueles impulsionados pelo próprio ministério, somente no início da década de 90, característica esta que nos ajuda a demarcar a transição para a próxima fase histórica dos CEAs no país, a qual abordaremos a seguir.

\section{C - Fase da Efetivação (1993 - 1997)}

Por que efetivação? Porque as iniciativas passam a emergir com mais freqüência, sob responsabilidade de diversos outros setores da sociedade. É nesta fase que podemos estabelecer convergência com o que coloca Viola (1991) relativo ao multissetorialismo do ambientalismo. É nesta fase que, de fato, verifica-se a efetiva participação de diversos setores da sociedade na implementação de propostas de CEAs. Enquanto nas duas primeiras fases tem-se uma certa dicotomia ou bissetorialismo, segundo o próprio Viola (1991), de iniciativas públicas e iniciativas da sociedade civil organizada, sobretudo ONGs e Associações, nesta fase observa-se a entrada efetiva de outros segmentos neste campo, como os setores empresarial e industrial, o que já era verificado sobretudo a partir do final da década de 80 e início dos anos 90. 
As datas que delimitam esta fase foram propostas com base em algumas características e acontecimentos marcantes para os CEAs no país. Ela inicia-se em 1993 com a formalização dos projetos pilotos de CEAs, propostos no ano anterior, como vimos anteriormente, e também com a movimentação ao redor da elaboração da primeira versão do Programa Nacional de EA (PRONEA ${ }^{30}$ ). Finaliza em 1997 com a realização do IV Fórum de EA, em Guarapari - ES, promovido pela Rede Brasileira de EA e da I Conferência Nacional de EA (CNEA), realizada em Brasília - DF e promovida pelo MEC e pelo MMA.

Iniciamos esta fase da Efetivação, em 1993, ainda à luz de alguns desdobramentos da ECO - 92 e de outros acontecimentos e eventos mais diretamente relacionados com a temática dos CEAs. Como um importante desdobramento "oficial" tem-se o delineamento da primeira versão do Programa Nacional de Educação Ambiental (PRONEA), em 1994.

"O PRONEA é encomendado em 1994 pelo então ministro do MMA ao IBAMA, Henrique Brandão Cavalcanti. Este órgão cria um Grupo de Trabalho integrado por educadores da Divisão de Educação Ambiental (DIED) do próprio IBAMA, o qual incumbe-se pela elaboração da proposta. A primeira versão é então re-elaborada por educadores do MEC e por técnicos da UNESCO (Pedrini, 1997, p.38-39).

Verifica-se, nesta proposta do PRONEA, dentre as sete Linhas de Ações que propõe, que a última delas (sétima) aponta para a "criação de uma rede de centros especializados em educação ambiental, integrando universidades, escolas profissionais, centros de documentação, em todos os Estados da Federação" (Brasil, 1997, p.13).

Também se observa no documento que, apesar da preocupação de se estabelecer alguma linha de ação específica para a temática dos Centros de Educação Ambiental, há certa incompreensão quanto à concepção do conceito de Rede, sobretudo pelo fato de que, para implementar tal Rede, o Programa propõe como principal ação estratégica:

\footnotetext{
${ }^{30}$ Este trabalho faz uma referência à primeira versão do Programa Nacional de EA - PRONEA, elaborada em 1994. A nova versão, de 2003, encontra-se em fase de consulta nacional, e pode ser acessado por meio do site http:// www.mma.gov.br/educambiental.
} 
"Implantar um Centro Nacional de Educação Ambiental, com o objetivo de organizar e articular a Rede de Centros Especializados, apoiar e consolidar suas atividades, dar-Ihe apoio técnico e armazenar dados e informações de interesse para o Programa Nacional de Educação Ambiental (Brasil, 1997, p.14).

Entendemos que há outra compreensão do conceito de Rede, haja vista que o trabalho em rede pressupõe alguns princípios, tais como descentralização e horizontalidade. Implementar uma Rede de CEAs sintonizados com estes princípios (e diversos outros) passa pela promoção do "enraizamento" das iniciativas nos âmbitos local, regional e estadual, principalmente por meio do estímulo ao protagonismo delas próprias e não pela criação de um Centro Nacional que centralize este processo.

Sem adentrar na discussão sobre redes, cabe ressaltar que não há consenso no campo da EA com relação à necessidade de implantação de um Centro Nacional para desenvolver e coordenar as diversas iniciativas de CEAs no país.

Ao retomarmos tal ação estratégica proposta pelo PRONEA, verificamos que na prática a mesma não se concretizou. Nesta fase (1993 - 1998), observa-se um considerável "boom" de iniciativas, ligadas aos mais variados setores da sociedade. Uma característica bastante relevante nesta fase é que o setor governamental, que nas fases anteriores, havia marcado sua atuação, sobretudo, por meio da proposição de decretos, documentos e pronunciamentos, em uma tentativa de "oficializar" os CEAs, sai aos poucos de campo e começa a perder espaço para outros setores.

Ressaltamos, entretanto, que esta saída de campo governamental (federal) não ocorre de forma abrupta, mas paulatinamente. É possível destacar dois acontecimentos "oficiais" relevantes para esta fase: o processo de elaboração, iniciado em 1994, que culminou na primeira versão do PRONEA em 1997 e a realização do II Encontro Nacional de Centros de Educação Ambiental, em Brasília no ano de 1996.

Quanto ao primeiro acontecimento, tecemos algumas considerações anteriormente com o objetivo de retratar e identificar as ações delineadas por tal documento com relação aos CEAs. Do segundo evento citado, o II Encontro Nacional de CEAs, não se tem qualquer registro a não ser uma listagem dos participantes que lá estiveram durante os dias 19 e 21 de agosto de 1996. É possível apenas constatar em 
tal listagem (MEC, 1996), que a maioria dos participantes são oriundos de órgãos públicos.

Quanto às características gerais desta fase, é possível encontrar algumas considerações importantes em diversos autores dos campos da Educação Ambiental e do Ambientalismo brasileiro.

"O movimento ambientalista brasileiro, nesse estágio do seu desenvolvimento, é caracterizado pela contradição entre sua fragilidade institucional e falta de recursos suficientes até para se erguer acima do voluntariado ou semi-voluntariado, por um lado; e a dedicação apaixonada de seus ativistas, a adequação e argúcia de sua abordagem analítica para compreender os dilemas de nossa época, os desafios e as oportunidades do Brasil" (Mafra, 1993, p.18).

Em relação ao campo da EA, observa-se a realização do III e IV Fóruns de EA, respectivamente em 1994 e 1997.

"Nos quatro fóruns realizados ${ }^{31}$, a marca registrada foi a tentativa de se criarem novas formas de ler os processos de formação das cidadanias, das maneiras de instruir, informar, educar as futuras gerações, procurando recriar falas e comportamentos sustentados por uma ética de preservação e desenvolvimento com harmonia (Cascino, 1999, p.44).

Um importante desdobramento de tais Fóruns foi a força que ganhou a proposta de organizar-se e atuar em redes.

"A partir desses "encontros", passamos a trabalhar a idéia de redes de educadores, de redes de trocas, de encontros, de interesses. Essa concepção atual e interessante de se praticar o ato político - a rede -, vem tendo grande desenvolvimento com a utilização de recursos eletrônicos (Internet)" (Cascino, 1999, p.44).

\footnotetext{
${ }^{31}$ São eles, segundo Cascino (1999, p.44): I Fórum de EA, realizado em 1989 em São Paulo; o II Fórum pré ECO-92, em abril de 1992, São Paulo; o III Fórum, na PUC-SP, em agosto de 1994 e o IV entre os dias 5 e 8 de agosto de 1997, em Guarapari - ES.
} 
Sorrentino (1993) em documento elaborado sob encomenda do MEC comenta o processo de formação de diversas redes no país, ressaltando algumas de suas características e apontando para os possíveis perigos que correm, como vemos abaixo:

"A formação de redes de Edcucação Ambiental ou de educadores ambientais, atualmente em construção em São Paulo, Espírito Santo, Bahia, Rio de Janeiro, e no país (além de uma planetária e uma latinoamericana com conexões no Brasil) e inúmeras outras experiências embrionárias que estão acontecendo, em nível municipal, são tentativas de intercâmbio constante das ações dispersas. Seria interessante, portanto, realizar um mapeamento mais abrangente dessas experiências e uma avaliação da influência das mesmas sobre as políticas públicas para o setor.(...) Indivíduos e grupos conectados na aldeia global, formando redes capazes de influenciar políticas públicas e grupos econômicos. Redes que fortalecem a ação local, através do intercâmbio de idéias e experiências, e ecoam as necessidades e propostas daqueles que vivem a realidade cotidiana e querem um maior domínio sobre ela.(...) Porém, essas redes incorrem no perigo de serem a grande novidade que se esvai nos velhos erros do diálogo de elites distantes das raízes da sociedade. É necessário aprofundar a capacidade de expansão dessas redes, em nível local, envolvendo os pequenos grupos/tribos/pessoas dispersos pelos bairros, sindicatos, igrejas, escolas. Caso contrário, serão grandes redes nacionais, porém ainda de elite e, portanto, fadadas a decidirem coisas maravilhosas que não se concretizarão, pois expressivas parcelas da população permanecerão distantes da motivação/mobilização no sentido de efetiválas" (Sorrentino, 1993, p.15-16).

Esta fase encerra-se com a realização da I Conferência Nacional de Educação Ambiental (CNEA), promovida pelo MEC e pelo MMA, a qual culminou no documento "Declaração de Brasília para a Educação Ambiental", que apresenta considerações acerca de cinco áreas temáticas propostas: 1- EA e as vertentes do desenvolvimento sustentável; 2- EA Formal - papel, desafios, metodologias, capacitação; 3 - EA no 
processo de gestão ambiental - metodologia e capacitação; 4 - EA e as políticas públicas - PRONEA, políticas urbanas, de recursos hídricos, agricultura, ciência e tecnologia; e 5 - EA, ética, formação da cidadania, educação, comunicação e informação da sociedade. O documento faz menção à questão dos Centros de Educação Ambiental no âmbito do item de número dois, ou seja, ligado ao ensino formal. Aponta algumas recomendações para o financiamento de projetos pilotos de EA no nível formal e para apoiar a criação de centros de excelência em EA (Czapski, 1998).

Em nenhuma outra área temática proposta pela Declaração verifica-se a inclusão de qualquer recomendação à questão dos Centros de Educação Ambiental. Tal documento vem reforçar nosso argumento de que a temática dos CEAs junto ao governo federal vinha sendo historicamente tratada num âmbito bastante restrito, ou seja, vinculada somente ao Ensino Formal.

Tal evento (I CNEA) foi promovido com o intuito de sistematizar experiências e ações em EA para serem levadas à Conferência Internacional sobre Meio Ambiente e Sociedade: Educação e Consciência Pública para a Sustentabilidade, conhecida simplesmente como Conferência de. Esta foi realizada na Grécia, na cidade de Thessalonik, no período de 8 a 12 de dezembro de 1997 (dez anos após a Conferência de Moscou e vinte anos após a Conferência de Tbilisi) e uma de suas recomendações foi a de promover-se "uma nova conferência internacional no ano de 2007, para verificar a implementação e o progresso do processo educacional sugerido" (Czapski, 1998, p.74).

\section{D - Fase Atual (1998- 2003)}

Em 1998, a partir da instituição e do lançamento do Programa de Núcleos Regionais de EA (NREAs) no Estado de São Paulo, por meio do decreto $n^{\circ} 42.798$ do então governador Mário Covas (São Paulo, 1998), delineia-se a transição para a fase atual dos CEAs.

A proposta dos NREAs emerge com uma concepção muito mais ampla do que a concebida pelo MEC, como visto nas Fases anteriores. Os NREAs não foram 
formalizados como extensão ou complemento da escola, mas com a missão de promover a articulação e a integração entre os diversos setores da sociedade.

"Esse Núcleos constituem-se como fóruns de integração e participação interinstitucional regional para otimização dos recuros materiais, humanos e financeiros, tendo em vista o desenvolvimento de projetos e ações de educação ambiental que estimulem o exercício da cidadania, configurandose, portanto, como um instrumento de ação e mecanismo para fluxo de informações $^{32}$ ambientais entre as diversas regiões do Estado e a Coordenadoria de Educação Ambiental do SMA. (...) tendo como meta a promoção da educação ambiental em âmbito regional, capacitando professores e técnicos de órgãos governamentais e entidades ambientalistas, para que atuem como agentes multiplicadores de educação ambiental nas suas respectivas regiões" (São Paulo, 1998, p.45).

Embora tenham sido concebidos com um enfoque mais amplo que os projetos pilotos de CEAs do MEC, os NREAs também surgiram como uma proposta voltada para o fluxo de informações, reforçando uma compreensão de CEAs como sendo espaço de disponibilização e acesso a informações e conhecimentos. Já mencionamos anteriormente que um CEA pode cumprir finalidades bem mais amplas do que estas, embora perceba-se na atualidade, que há uma tendência de se planejar e implementar CEAs com este viés.

Com relação a questão dos agentes multiplicadores, combatemos esta concepção por acreditar que traz embutida uma concepção tradicional de educação, denominada por Paulo Freire como sendo "educação bancária". Esta concepção aponta para uma educação centrada na transmissão de conhecimentos de quem os detêm (professor, técnico, especialista) para quem não os detêm (aluno, comunidade, agricultor). Emerge deste pressuposto, então, o termo agentes multiplicadores para

\footnotetext{
${ }^{32}$ Grifo nosso.
} 
designar aqueles que irão disseminar e multiplicar determinado conhecimento num certo contexto ou comunidade, ou seja, depositá-lo33.

A fase atual inicia-se com as discussões acerca da aprovação de uma Política Nacional de Educação Ambiental (PNEA - Lei 9.795/99) no Congresso Nacional. Os debates sobre a construção desta Proposta de Lei estavam sendo "travados" desde meados da década de 90, mas é, sobretudo, ao final dela que ganham mais impulso.

É nesta fase, também, que se verifica um fabuloso "boom" de iniciativas de CEAs, ligadas aos mais diversos segmentos da sociedade. $\mathrm{Na}$ fase anterior (da "Efetivação", 1993 - 1997) já se observava este avanço, sobretudo pelos desdobramentos e influências que a ECO - 92 (e toda a sua mobilização) propiciou no campo da EA de uma forma geral. Na fase atual o que se verifica é que a explosão de novas iniciativas de CEAs vem ocorrendo em grande medida pelo acúmulo e avanços alcançados pelas iniciativas que se estabeleceram, no país, nas fases anteriores, sobretudo na Fase da "Efetivação" (1993 - 1997).

A fase atual pode ser caracterizada por importantes avanços no campo da EA de um modo geral. Merece destaque no campo legal a PNEA, compreendendo a Lei ${ }^{\circ}$ 9.795 de 27 de abril de 1999 e o Decreto $n^{\circ} 4.281$ de 25 de junho de 2002, que a regulamenta. Este, em especial, cria o Órgão Gestor e o Comitê Assessor, responsáveis pela implementação da Lei 9.795. Embora não citem qualquer ação específica sobre a temática dos CEAs, entendemos que há abertura para se avançar no estudo, articulação e ação no âmbito dela.

Outros avanços que podem ser mencionados, nesta fase, são de âmbito organizacional e prático. Alguns CEAs começam a participar com mais força na organização de redes estaduais e regionais de EA, constituindo-se em "elos" potenciais de algumas destas redes. Emerge, também, a proposta da Rede Brasileira de Centros de Educação Ambiental - Rede CEAs - junto à qual o presente estudo tem considerável influência pois, à medida que as diversas iniciativas de CEAs no país passaram a ser mapeadas e um pouco mais conhecidas, ganha força a proposta de atuação em rede junto a esses coletivos. A organização em rede tinha como objetivo imediato promover intercâmbios entre educadores ambientais ligados a estas iniciativas, contribuindo para estimular o diálogo entre eles, a troca de informações, de

\footnotetext{
33 Preferimos a adoção do termo Agentes Editores, em referência ao termo Autor-Cidadão (Barbosa, 1998), que o considera como um sujeito, que deve ser responsável pelo seu próprio processo de construção do conhecimento, marcado pelo seu protagonismo e por sua postura pró-ativa.
} 
idéias, de experiências, tendo como foco maior fortalecer suas ações e suas próprias iniciativas e divulgá-las no âmbito na EA de um modo geral.

Todo esse processo encontra-se em marcha. A Rede CEAs está em formação e preocupando-se em consolidar-se como sendo uma alternativa aos CEAs no país, mas sem qualquer pretensão de ser a única. Há inúmeros outros mecanismos que podem potencializar estes objetivos e que devem ser perseguidos. A Rede realizou ou contribuiu para realizar ao menos, quatro eventos relevantes que merecem ser destacados: a) I Encontro Paulista de CEAS (EPCEAs), realizado em Rio Claro - SP, em julho de 2003 , b) os I e II Encontro dos CEAs do Estado do Rio de Janeiro, respectivamente realizados em 2003 e 2004, nas cidades de São Gonçalo e Rio de Janeiro; e c) Encontro Nacional de CEAs (ENCEAs), realizado em outubro de 2003, em Timóteo - MG. Deste último, resultou um documento denominado a "Carta de Timóteo", que busca orientar os trabalhos da rede e propõe algumas recomendações.

Paralelamente a estes eventos, observou-se no país, em especial após 2002, que educadores ambientais passaram a olhar com mais atenção para a temática dos CEAs, reconhecendo sua relevância e a necessidade de discussão em separado, haja vista suas especificidades. O ano de 2004, por sua vez, merece ser destacado por tratar-se do ano de realização do V Fórum Brasileiro de EA, a ser realizado em Goiânia - GO. O último Fórum, realizado em 1997, em Guarapari - ES, representou um marco para a EA brasileira.

Trata-se de uma importante oportunidade de avanços ainda mais relevantes para a temática dos CEAs, sobretudo por alguns fatores:

a) Possibilidade de divulgação da Rede CEAs e da temática dos CEAs junto a segmento da EA como um todo, tanto junto a Educadores Ambientais que estão em atividade há mais tempo quanto aquelas pessoas interessadas com a temática e que estão iniciando sua trajetória nesta área;

b) Fortalecimento da Rede e das iniciativas por meio da troca de experiências e de informações, de articulações, do estabelecimento de parcerias, dentre outras possibilidades de cooperação e de intercâmbios;

c) Possibilidade de articulação com outros segmentos, até então pouco presentes na Rede CEAs: os NEAs do IBAMA e outras Redes existentes (como a Rede Universitária de Programas de EA - RUPEA, a Rede da Juventude pelo Meio Ambiente - REJUMA, dentre outras); 
d) Fortalecimento da interação entre os CEAs, a Rede CEAs e a Rede Brasileira de EA - REBEA, objetivando consolidar a Rede CEAs como sendo uma rede temática que é parte integrante da REBEA.

Por fim, é provável que o $V$ Fórum Brasileiro de EA possa constituir-se num divisor de águas da temática dos CEAs, acontecimento este que necessitará de tempo para ser observado e analisado. Porquanto ainda estamos no que chamamos de Fase Atual, consideravelmente marcada pela consolidação das iniciativas de CEAs no país, mas muito mais do que isso. Tem-se estas iniciativas em franca atividade e iniciando o estabelecimento de um processo de conexões e de organização em rede. Talvez esta seja a grande característica desta fase, quando os CEAs já estão enraizados (ainda que mal distribuídos pelo país) e buscando conectarem-se uns aos outros, com objetivos comuns, de fortalecimento mútuo e melhoria da sua práxis cotidiana, e de formulação e implementação de propostas de políticas públicas para esta área.

\subsubsection{Algumas considerações sobre Educação Ambiental (EA), Ambientalismo e Educação}

"Se um homem não pensar sobre o que está distante, ele encontrará tristeza muito próximo de si".

(Confúcio)

Falar da ou sobre a Educação Ambiental requer assumir certos questionamentos. Porém não apenas assumi-los e ponto. Exige todo um processo de interiorização e de processamento de cada uma destas questões, produzindo seu próprio repertório de questionamentos e tentativas de respostas. Tentativa porque não se trata apenas de um leque de questões e de respostas, como uma lista de exercícios que o professor distribui a seus alunos como tarefa, mas sim de um conjunto de questionamentos que exigem dos indivíduos profundas reflexões acerca de cada um deles. Fala-se muito acerca de valores, atitudes, comportamentos e consciência no campo da Educação Ambiental. Mas, afinal, como as práticas de Educação voltadas à questão ambiental, realizadas no Brasil têm enfrentado esses questionamentos? Como 
os educadores ambientais têm enfrentado esse processo de mapear, interiorizar, "mastigar", refletir sobre seu próprio repertório de questionamentos e dúvidas sobre a EA? Como este processo pode constituir-se em importante substrato para a práxis do educador ambiental?

Diversos são os questionamentos que compõem, neste momento, nosso repertório pessoal. Cabe-nos destacar o quão importante são estas dúvidas e o quanto podem (e devem) contribuir para a nossa práxis na Educação Ambiental. Questões que emergem da problematização das obviedades do nosso mundo pós-moderno, da constatação de práticas e de teorias no campo da EA que bebem em fontes distintas de pressupostos que norteiam esse campo. De fato, ao partir do questionamento de certas obviedades com as quais nos deparamos no dia a dia e na práxis cotidiana do educador ambiental é possível ir elencando cada uma destas dúvidas. Questões relativas à Educação Ambiental como: separar lixo ou não produzi-lo? Apontar caminhos ou fortalecer os caminhantes? Mais importância às técnicas ou aos princípios? EA: local ou global? Ensinar crianças ou reeducar adultos? Informar ou mobilizar? Agentes multiplicadores ou editores? Desenvolvimento Sustentável ou Sociedades Sustentáveis? Preservação ou conservação? Multi, inter ou transdisciplinaridade? Educação Ambiental restrita a eventos isolados e a determinadas faixas etárias ou processo contínuo e permanente?

São questões extremamente complexas, que nos remetem a um campo teórico bastante denso e complexo. Falar sobre interdisciplinaridade, por exemplo, requer acessar a um repertório teórico consideravelmente rico e, até certo ponto, divergente. Não é preciso, entretanto, que haja consenso no campo da EA. O que interessa é o debate de idéias, de opiniões, de pontos de vista. Mas é preciso que identifiquemos e conheçamos as distintas correntes existentes situando nossa "filiação". Evidentemente que não se trata de filiar-se a este ou aquele grupo, esta ou aquela tendência, este ou aquele partido. O campo da EA é extremamente rico, complexo, diversificado, polimórfico e polissêmico, o que dificulta qualquer tentativa de identificação de facções. De fato, não há facções na EA. O que há são correntes que bebem em determinados pressupostos da EA, compartilham certos fundamentos do ambientalismo e se identificam com dados princípios, propostas e autores do campo educacional. 


\subsubsection{Educação Ambiental: fortalecendo caminhantes ${ }^{34}$}

O intuito deste trecho relativo à Educação Ambiental não é o de trazer informações sobre marcos e acontecimentos históricos que contribuíram para a clarificação de relevantes conceitos norteadores da EA, por consideramos que, de certa forma, isso foi parcialmente feito nos itens anteriores deste trabalho. Neste momento, estamos mais interessados em levantar e discutir algumas questões importantes no campo da EA que nos acompanham e intrigam.

Sabemos que não se trata de nenhuma novidade que:

"Educar para o meio e educar a partir do meio, não são propostas novas" (...) A natureza e o meio como recursos educativos já eram mencionados por antepassados ilustres como Rousseau (1712-1778) e Freinet (18961966) e diversas correntes pedagógicas têm insistido, ao longo do tempo, sobre a necessidade de recorrer à experiência e ao estudo do meio como estratégia de aprendizagem e de preparação do indivíduo para a vida" (Sorrentino, 1993, p.7).

É importante observar que há fatos e acontecimentos que são recorrentes nas diversas histórias das distintas educações ambientais brasileiras. Eventos que ficaram marcados como sendo importantes momentos de debates de idéias e sistematização de conceitos chave para a EA. Conferências, congressos e encontros que atualmente são mais conhecidos pelos nomes das respectivas cidades que os acolheram. Cidades que, de certa forma, ficaram marcadas no campo da EA, dentre elas: Estocolmo (1972), Belgrado (1975), Tibilisi (1977), Moscou (1987), Rio de Janeiro (1992), Thessalonik (1997). Estas ${ }^{35}$ (e outras) ficaram destacadas no âmbito mundial, sediando importantes eventos globais sobre Meio Ambiente, Educação Ambiental, Desenvolvimento, Sociedade e Sustentabilidade.

\footnotetext{
34 Em referência ao que coloca Rosa(2001): "Então, a essência da educação ambiental não é "apontar caminhos" mas sim "preparar e fortalecer os caminhantes".

${ }^{35}$ Tais cidades sediaram eventos como: Conferência das Nações Unidas sobre o Meio Ambiente Humano (Estocolmo, 1972); The Belgrado Workshop on Envirionmental Education (Encontro de Belgrado, 1975); Conferência Intergovernamental sobre Educação Ambiental (Tbilisi, 1977); Congresso Internacional de Educação e Formação Ambientais (Moscou, 1987), Congresso das Nações Unidas sobre Meio Ambiente e Desenvolvimento - Rio-92 (Rio de Janeiro, 1992); Conferência Internacional sobre Meio Ambiente e Sociedade: Educação e Consciência Pública para a Sustentabilidade (Thessalonik, 1997).
} 
É possível apontar diversas outras cidades, no Brasil e no mundo, que sediaram uma infinidade de eventos que marcaram o campo da EA. No caso brasileiro ocorreram eventos locais, regionais, estaduais, nacionais, que marcaram e contribuíram para o enraizamento da EA no país. Quanto aos eventos de maiores dimensões, estes ficaram marcados mais facilmente no campo da EA, demarcando seus nomes na história da EA brasileira, e são constantemente citados e mencionados por educadores ambientais, livros e outros trabalhos de EA. Cidades como: Porto Alegre, Rio de Janeiro, São Paulo, Guarapari, Brasília, Foz do Iguaçu. Todas elas ${ }^{36}$ contribuíram (e contribuem) para configurar o cenário atual da EA brasileira. Cabe ressaltar que há muitas outras cidades que sediaram eventos de grande significado para a EA brasileira (encontros, congressos, feiras, exposições, workshops, seminários, etc) e que marcaram momentos, localidades, regiões no campo da EA. Cada educador ambiental tem em sua própria trajetória seu repertório de eventos, de acontecimentos, de fatos que o marcaram e acompanham em seu caminhar na sua práxis cotidiana.

Cumpre-nos dizer que, para além dos eventos, fatos e acontecimentos considerados chaves na história "oficial"37 da EA brasileira, é extremamente importante considerar a trajetória individual de cada educador ambiental pelos meandros desse complexo, denso e dinâmico campo da Educação Ambiental. Cada educador ambiental traz consigo (e constrói a cada momento) seu repertório próprio de conceitos, de significados, de valores, de condutas, de saberes. Traz consigo sua própria bagagem de EA, construída a partir desta trajetória pela EA. Uma trajetória que é compartilhada com muitos que por estas trilhas se embrenham e se aventuram.

É necessário conhecermos a história dita "oficial" das EAs brasileira e mundial ${ }^{38}$, mas também saber aplicar os diversos desdobramentos dos acontecimentos chave desta história em nossa práxis cotidiana. Saber conceber o significado contextualizado, saber aplicá-lo à realidade local é desafio. Acreditamos que esta

\footnotetext{
${ }^{36}$ Tais cidades sediaram importantes eventos e foram palcos de acontecimentos históricos no campo da EA: e do ambientalismo brasileiro: Porto Alegre (1971, criação da Associação Gaúcha de Proteção ao Ambiente Natural - AGAPAN); Rio de Janeiro (1958 - Criação da Fundação Brasileira para a Conservação da Natureza - FBCN; 1986 - Fundação do Partido Verde (PV); Rio-92); São Paulo (1956 Fundação da Associação de Defesa da Flora e da Fauna; 1990, 1992 e 1994 - respectivamente I, II e III Fóruns Brasileiros de EA); Guarapari (1997 - IV Fórum Brasileiro de EA); Brasília (1996 - II Encontro Nacional de Centros de Educação Ambiental; 1997 - I Conferência Nacional de EA); Foz do Iguaçu (1992 - I Encontro Nacional de Centros de Educação Ambiental).

37 Em alusão àquela contada nas diversas obras (livros, teses, cartilhas, vídeos, etc) de educação ambiental disponíveis no momento no Brasil.

${ }^{38}$ Será que têm mais divergências que semelhanças?
} 
"costura" entre fatos, acontecimentos, marcos da história "oficial" da EA e os marcos pessoais decorrentes da trajetória de cada indivíduo pelos meandros da EA constitui desafio chave na atuação do educador ambiental brasileiro. Referimo-nos a esta "costura" como sendo a busca constante de um "agindo localmente, pensando globalmente (e vice-versa) e trabalhando-se interiormente" (Sorrentino, 2000, p.113). Daí a necessidade de pensarmos numa EA que "prepare e fortaleça os caminhantes", em vez de "apontar caminhos", de uma EA que "clama pela liberdade de expressão, pela autonomia, pela diversidade e pela emancipação para a transformação de sociedades" (Sato, 2001, p.20); de uma EA de "vocação múltipla e diversa em diferentes planos e dimensões" (Brandão, 2002, p.25) ${ }^{39}$. Quando apontamos para o "pensar numa EA" estamos partindo do pressuposto de que são várias as educações ambientais brasileiras ${ }^{40}$ e que cada educador ambiental constrói a sua EA, e que, embora relacione-se com este ou aquele conjunto de idéias, autores e correntes, é um processo plenamente idiossincrático.

É com esta perspectiva que encaramos a EA brasileira. Procuramos destacar alguns acontecimentos da história "oficial" da EA, reconhecendo que constituem referências, mas que devem ser interiorizadas em cada educador ambiental para que reverbere no interior do indivíduo e que estimule a produção de seus próprios significados. Embora exista uma considerável pluralidade de concepções de EA no Brasil e uma diversidade de campos do saber com os quais a EA dialoga, é possível mapear algumas áreas com as quais a EA encontra maior convergência. Ressaltamos que estas considerações foram tecidas a partir de uma "filiação" a uma matriz emancipatória de EA, segundo Carvalho (1997). Basicamente, são dois os grandes campos do saber nos quais a EA navega e trilha suas trajetórias com mais ênfase: o do Ambientalismo e o da Educação. Teceremos considerações relativas a cada um destes campos, buscando alinhavar e costurar algumas de suas diversas interfaces e como elas deságuam no campo da EA.

\footnotetext{
${ }^{39}$ BRANDÃO, C.R. Projeto Biodiversidade, sustentabilidade e Educação Ambiental. / Encaminhado à FAPESP em 2002l

40 Em concordância com o que afirmam: "Atualmente não é mais possível entender a educação ambiental no singular, como um único modelo alternativo de educação que simplesmente se opõe a uma educação diversos setores da sociedade, tem sido associada a diferentes matizes de valores e interesses, gerando convencional" (Layrargues, 2002, p. 136); e "A EA, ao expandir sua área de visibilidade e adesão pelos um quadro bastante complexo de Educações Ambientais com orientações metodológicas e políticas bastante variadas" (Carvalho, 1997, p.278).
} 
Uma destas interfaces remete-nos para a necessidade de pensar e praticar uma Educação voltada à questão Ambiental, que vislumbre cinco dimensões da questão ecológica que, segundo Sorrentino (1993) são:

1) Ecologia da Alma (aquela que abriga nossos sentimentos, alma, espírito, imaginário, paixões);

2) Ecologia do Corpo (relativa à alimentação, respiração, movimentos)

3) Ecologia das Relações com o outro (dinâmicas de grupo, relações interpessoais e transpessoais);

4) Ecologia das Relações com a natureza e com o ambiente construído (distanciamento da natureza, impermeabilização dos solos, erosão, poluições)

5) Ecologia Política (formas de gestão do espaço comum, legislação, políticas públicas, convenções, acordos, tratados).

De fato, a perspectiva apontada por Marcos Sorrentino (a das cinco ecologias) concede-nos importante substrato de reflexão acerca das interfaces com as quais o campo da EA dialoga. Parece-nos central que pelo menos duas áreas se destacam, as quais estaremos abordando a seguir: uma que remete ao movimento ambientalismo e outra que remete ao campo pedagógico, o qual entendemos como sendo o campo da Educação.

\subsubsection{Ambientalismo: uma luta continuada pela participação}

O campo da ambientalismo apresenta inúmeras convergências com o da $E A$, sendo, em muitos momentos, até mesmo confundidos. Que o movimento ambientalista contribuiu (e contribui) para a formação e constituição da EA brasileira não se trata de novidade. Como buscamos destacar no tópico relativo ao "Histórico dos CEAs no Brasil", o ambientalismo caminhou conjuntamente com o campo da EA e também contribuiu para a constituição de iniciativas de Centros de Educação Ambiental no Brasil, ainda que saibamos pouco sobre essa "história". Talvez o principal aporte trazido pelo movimento ambientalista para a EA tenha sido o do campo dos embates e da participação, iniciado por meio de denúncias de degradadores ambientais, até alcançar, mais recentemente, a dimensão da luta política (não partidária e partidária) e da articulação social com relevante viés emancipatório. É possível vislumbrar aqui importante conexão deste campo com o da Educação, considerando-a numa 
perspectiva também emancipatória, pautada no diálogo e na constituição de comunidades de aprendizagem. Buscaremos discutir este campo logo à frente. Por enquanto, seguimos na discussão inerente ao campo do ambientalismo, suas conexões e inter-relacionamentos com a EA no Brasil.

Encontramos três abordagens sobre o ambientalismo brasileiro, de acordo com Leis (1996), quais sejam: grupo de pressão, novo movimento social e movimento histórico.

"De acordo com a primeira perspectiva, o ambientalismo seria um grupo interno ao sistema político, que se constitui a partir de uma demanda de proteção ambiental para problemas bem definidos, sem contestar ou desafiar aspectos normativos e gerais do funcionamento da sociedade. $\mathrm{O}$ ambientalismo entendido como "novo movimento social" significa que a questão ambiental é tratada de forma crítica e alternativa em relação à ordem existente, sendo contextualizada de um modo fortemente normativo(...). A terceira perspectiva assume que o atual modelo de desenvolvimento é insustentável a médio ou longo prazo e que as transformações necessárias supõem a existência de um movimento multissetorial e global, capaz de mudar os principais eixos civilizatórios $^{41}$ da sociedade contemporânea" (Leis, 1996, p.113-114).

Sintonizados com esta terceira perspectiva, entendemos que ela seja a via mais efetiva de propiciar transformações profundas no panorama socioambiental atual global e possa representar a trilha rumo à constituição de sociedades sustentáveis. No entanto, entendemos também que promover as mudanças nos principais eixos civilizatórios, como apontado por Leis (1996) requer um princípio básico inerente a esta "corrente" do movimento ambientalista, que é o princípio da participação. Promover transformações desta natureza requer participar pró-ativamente deste processo.

Parece-nos claro que o ambientalismo dialoga e se inter-relaciona com a Educação Ambiental, sendo um dos seus principais contribuintes, em termos de conceitos, teorias, profissionais, reflexões, etc. Sem dúvida, há uma importante retroalimentação entre ambos campos do conhecimento, entre estilos e filosofias de

\footnotetext{
${ }^{41}$ Grifo nosso.
} 
vida, entre olhares e leituras de mundo. Em muitos casos e momentos o ambientalismo confunde-se com a educação ambiental. Partindo destas considerações, vislumbramos diversos conceitos e princípios do ambientalismo de que a EA se apropria e se nutre. Dentre eles, entendemos que o da participação seja um dos mais importantes, na atualidade, porque está sintonizado com uma perspectiva de EA emancipatória, crítica e política, desde suas origens no país.

"A força que tem a educação ambiental brasileira se deve a sua origem militante, de intervenção e a uma prática independente das diretrizes oficiais dos ministérios e outros órgãos administrativos (Reigota, 2000, p.24).

Discutiremos as dimensões do conceito da participação à luz da sua contribuição ao campo da EA, em especial à temática dos CEAs no Brasil.

Se a EA encontra considerável convergência com o ambientalismo, não podemos perder o foco de que a EA pode ser encarada como sendo uma forma de educação voltada à questão ambiental, o que nos traz um outro campo, extremamente importante e não menos contribuinte para a EA, que é o da educação.

\subsubsection{Educação: por uma práxis dialógica}

Compreendendo, então, que o campo da EA dialoga mais diretamente com os campos do ambientalismo e da educação, percebemos que, entre eles, há consideráveis interfaces e interferências. Direcionando o olhar para o campo da educação, vislumbramos um cenário extremamente rico em conceitos, princípios e valores, que alimentam constantemente as teorias e práticas dos educadores ambientais. Desta forma, parece-nos ser indiscutível a importância da educação não somente para a EA, mas como uma ferramenta indispensável para o ato incessante de estar vivendo neste mundo, de acordo com Freire (2000):

"A educação tem sentido porque o mundo não é necessariamente isto ou aquilo, porque os seres humanos são tão projetos quanto podem ter projetos para o mundo. A educação tem sentido porque mulheres e homens aprenderam que é aprendendo que se fazem e se refazem, 
porque mulheres e homens se puderam assumir como seres capazes de saber, de saber que sabem, de saber que não sabem. De saber melhor o que já sabem, de saber o que ainda não sabem. A educação tem sentido porque, para serem, mulheres e homens precisam estar sendo. Se mulheres e homens simplesmente fossem não haveria porque falar em educação" (Freire, 2000, p.40).

A pintura que tecemos da educação remete-nos, então, para um panorama muito distante da tradicional visão de "transferência de conhecimentos", a conhecida educação bancária que Paulo Freire combateu. De fato, não temos qualquer dúvida de que "ensinar não é transferir conhecimento, mas criar as possibilidades para sua produção ou a sua construção" (Freire, 2002, p.25).

Criar estas possibilidades pressupõe uma postura dialógica, estar aberto ao diálogo, receptível à forma de interpretar do outro, disponível e atento para ouvir o outro.

"É preciso que saibamos que, sem certas qualidades ou virtudes, como amorosidade, respeito aos outros, tolerância, humildade, gosto pela alegria, gosto pela vida, abertura ao novo, disponibilidade à mudança, persistência na luta, recusa aos fatalismos, identificação com a esperança, abertura à justiça, não é possível a prática pedagógico-progressista, que não se faz apenas com ciência e técnica (Freire, 2002, p.136).

Falamos desta prática que Paulo Freire denominou como progressista, e que Dermeval Saviani intitula como pedagogia nova, cujo pressuposto é "aprender a aprender" (Saviani, 1987, p. 18). Falamos, então, de uma educação dialógica, aquela que pressupõe princípios essenciais como: a) respeito aos educandos, aos seus saberes, experiências e leituras do mundo; b) escutar as urgências dos educandos; e c) ser tolerante, que consiste na virtude de conviver com o diferente (Gadotti, 1991).

Temos clareza, no entanto, que as distintas educações ambientais existentes no país dialogam com, também, distintas correntes pedagógicas. Correntes estas que vão desde a transferência de conteúdos (educação bancária) até a problematizadora, como as classifica Paulo Freire. Sabemos que estas distintas tendências influenciam diretamente as práticas de educadores ambientais, tendo relevante "peso" no 
delineamento de Projetos Político-Pedagógicos de CEAs. Este nos parece ser o eixo central da discussão do inter-relacionamento entre o campo da educação com a temática deste trabalho, qual seja, a dos Centros de Educação Ambiental. Visualizar quais princípios pedagógicos norteiam as práticas de CEAs no país parece ser uma demanda essencial nesse diálogo.

Que princípios pedagógicos vêm norteando as práticas dos CEAs no país? Eles dialogam com a perspectiva de uma educação emancipatória, entendida como sendo aquela que tem como objetivo propiciar a emergência em cada sujeito da conquista da sua plena cidadania, identificada pela sua capacidade de auto-gestão, de participação política na construção de projetos de futuro pautados na democracia e na busca de qualidade de vida. Entendemos que esta visão de educação está diretamente sintonizada com o conceito de sociedades sustentáveis. Este considera que:

"O desenvolvimento não pode ser já a simples aplicação em todo o mundo de modos de pensamento, experiências, conhecimentos e modos de vida próprios de uma região ou de uma cultura: pelo contrário, a orientação e o ritmo do desenvolvimento deverão ser definidos de modo endógeno por cada sociedade em função das necessidades, dos objetivos socioeconômicos e das particularidades de seu meio ambiente, assim como das conseqüências do desenvolvimento sobre a biosfera...Significa também estimular a participação efetiva dos setores ativos da população no processo de concepção, decisão e controle das políticas inspiradas pelas novas óticas do desenvolvimento" (Gaudiano, 2002, p.28).

Buscaremos discutir mais amplamente dois princípios e conceitos que identificamos como sendo essenciais para a prática dos educadores ambientais de CEAs - o da participação e o do diálogo. Já vimos que ambos emergem do ambientalismo e da educação, e que têm desempenhado importante papel no campo da EA no Brasil, adensando a práxis dos educadores ambientais, ainda que de maneiras bem distintas. Parece-nos essencial, então, refletir sobre qual concepção de participação e de diálogo estamos bebendo para a construção deste trabalho. Há distintas abordagens relativas a estes conceitos, que serão explicitadas a seguir. 


\subsubsection{Por uma participação dialógica nas práticas de CEAs}

Considerando que os conceitos e princípios da participação e do diálogo são referenciais fundamentais para as práticas dos CEAs no país, tentaremos propor a fusão de ambos, na intenção de apontarmos para uma forma de participação que seja dialógica, pautada sempre na possibilidade e na realidade que é o diálogo. Para entendermos a proposta de uma participação dialógica, é preciso que reflitamos sobre cada um dos conceitos e princípios componentes deste novo conceito - participação e diálogo.

"Participação significa, do ponto de vista dos ambientalistas, especialmente os da América Latina, enfatizar a questão educacional, debatendo liberdades democráticas e modelos de gestão - como administrar nossos espaços comuns, desde os micro espaços cotidianos na família, na casa, no bairro, etc., até o planeta (Sorrentino, 2000, p.98).

O próprio autor entende que essa participação pressupõe:

a) A disponibilização de repertórios para que todos tenham condições de decidir. Para isto são necessárias políticas voltadas à veiculação constante e continuada de informações, através das escolas, dos meios de comunicação, comunitários e de massa, das redes formais e informais tecidas pelos grupos de convivencialidade, pelas instituições e através de outras formas que não privilegiem o saber erudito e os conhecimentos hegemônicos em detrimento de outros saberes e conhecimentos.

b) O fortalecimento e criação de espaços de locução - onde o aprendizado da participação se dê no exercício cotidiano do diálogo (da família à empresa; do grupo de amigos à escola; da associação de moradores às instâncias de poder do município, do Estado, do país), e na práxis do planejamento, nas ações e avaliações compartilhadas, solidárias e acima de tudo que valorizem a diversidade e confiem no potencial da contribuição de cada um para o grupo e para a sociedade.

c) A definição e aprimoramento de instâncias de decisão que, interagindo com os dois itens anteriores, possibilite o real sentido da participação e da cidadania, que é, a meu ver, o de envolvimento e de pertencimento a um 
grupo, projeto, empreendimento, espaço, de construção do futuro (Sorrentino, 2002, p.93).

O conceito de participação pressupõe, então, o diálogo, considerando-o como elemento básico para que se alcance algum grau de participação em alguma direção desejada. Falar sobre participação pressupõe, pelo menos, considerar a existência do conceito de qualidade política, entendida por Pedro Demo como:

\begin{abstract}
"A arte da comunidade de autogerir-se, a criatividade cultural que demonstra em sua história e espero para o futuro, a capacidade de inventar seu espaço próprio, forjando sua autodefinição, sua autodeterminação, sua autopromoção, dentro dos condicionamentos objetivos" (Demo, 2002, p.18).
\end{abstract}

Como vimos, o conceito de participação com o qual estamos sintonizados está intimamente ligado com a luta pela cidadania, pela intensidade comunitária, pela coerência ideológica e política, pela identidade cultural, pelo espírito de solidariedade e de transformação da realidade. Se o conceito da participação faz emergir todos esses outros conceitos vinculados, sobremaneira, aos diversos movimentos sociais (incluindo aí o ambientalista), promove também destaque a princípios pedagógicos essenciais para o campo da EA na atualidade. Já apontamos o diálogo como sendo um destes princípios-base para processos educacionais voltados à questão ambiental e é dele que trataremos a partir de agora.

Inicialmente, faz-se necessário identificarmos qual a concepção de diálogo que estamos sintonizados. Embora possa parecer simples a compreensão deste princípio, há consideráveis divergências no que diz respeito à sua conceituação.

"O diálogo proposto pelas elites é vertical, forma o educando-massa, impossibilitando-o de se manifestar. Nesse suposto diálogo, ao educando cabe apenas escutar e obedecer. Para passar da consciência ingênua para consciência crítica, é necessário um longo percurso, no qual o educando rejeita a hospedagem essa que faz com que ele se considere ignorante e incapaz. É o caminho de sua auto-afirmação enquanto indivíduo (...). o diálogo é uma relação horizontal" (Gadotti, 1991, p.66). 
O diálogo, então, passa a ser condição sine qua non para a ocorrência de processos educacionais voltados à questão ambiental, pautados na auto-promoção de seres humanos, que visem instrumentalizar cidadãos potencializando sua capacidade de ação, de intervenção, de transformação de realidades socioambientais, culturais, políticas, econômicas. Então "o diálogo não é um método e não é uma estratégia. Ele é uma finalidade" (Brandão, 1997, p.32).

"Quando tentamos um adentramento no diálogo como fenômeno humano, se nos revela algo que já poderemos dizer ser ele mesmo: a palavra. Mas, ao encontrarmos a palavra, na análise do diálogo, algo mais que um meio para que ele se faça, se nos impõe buscar, também, seus elementos constitutivos. Esta busca nos leva a surpreender, nela, duas dimensões: ação e reflexão, de tal forma solidárias, em uma interação tão radical, que, sacrificada, ainda que em parte, uma delas, se ressente, imediatamente, a outra. Não há palavra verdadeira que não seja práxis.(...) A existência, porque humana, não pode ser muda, silenciosa, nem tão pouco pode nutrir-se de falsas palavras, mas de palavras verdadeiras, com o que os homens transformam o mundo. Existir, humanamente, é pronunciar o mundo, é modificá-lo. O mundo pronunciado, por sua vez, se volta problematizado aos sujeitos pronunciantes, a exigir deles novo pronunciar. Não é no silêncio que os homens se fazem, mas na palavra, no trabalho, na ação-reflexão.(...) O diálogo é este encontro dos homens, mediatizados pelo mundo, para pronunciá-lo, não se esgotando, portanto na relação eutu.(...) o diálogo é uma exigência existencial" (Freire, 1999, p.77-79).

Considerando todas estas dimensões identificadas com relação aos conceitos e princípios chave deste tópico diálogo e participação, encontramos consideráveis convergências entre seus referenciais teóricos e campos de atuação prática. Embora possamos verificar, a partir da visita à literatura apontada neste tópico, certa redundância entre os termos participação e diálogo, optamos por manter os dois conceitos presentes na mesma expressão - participação dialógica - como forma de reforçar a necessidade do diálogo em qualquer processo educacional que se proponha participativo. 
Estes processos requerem a identificação e o delineamento de estratégias que permitam, na prática, a constituição de espaços de interlocução, de diálogo propriamente dito, e a construção de momentos e de instâncias de tomadas de decisão, de forma horizontal, para além de uma mera disponibilização de informações.

E é justamente sobre a implementação destes conceitos e princípios que o próximo tópico abordará, identificando as principais dimensões do Projeto Político Pedagógico voltados para CEAs e como estes constróem seus Projetos PolíticoPedagógicos norteando-se e relacionando-se com os dois princípios chave devidamente apresentados neste item.

\subsubsection{Projeto político-pedagógico na perspectiva de CEAs}

Optamos por abordar conceitualmente a questão do projeto político pedagógico tomando como referência trabalhos que tratam deste tema relacionado, sobretudo, ao ensino formal (Menezes, 1999; Garcia, 1999; Veiga \& Fonseca, 2001 e Veiga, 2002) pelo fato de não encontrarmos na literatura do campo da EA qualquer menção ao tema.

É preciso ressaltar que se observa na prática, no âmbito dos CEAs, alguma variação de denominações relativas a este termo, que aqui estamos tratando como Projeto Político-Pedagógico (daqui adiante PPP), mas que encontramos, tanto na literatura como na prática, denominações como: programa educativo, projeto pedagógico, projeto educativo, programa de educação ambiental, dentre outras. Verificamos na literatura que esta constatação não é exclusiva da temática dos CEAs, mas se faz presente no âmbito da escola.

"Verifica-se uma falta de clareza terminológica, sobretudo no tocante a sua documentação. Na maioria destes estudos se pode encontrar termos como "projeto pedagógico", "projeto educacional", projeto educativo", "projeto curricular" como também termos que tampouco mencionam a noção de projeto, tais como "proposta pedagógica", "plano pedagógico", "proposta educacional", "plano educacional", "plano diretor", "plano escolar", dentre outros. E freqüentemente estes termos coexistem com os termos "projeto político-pedagógico" ou "projeto escolar". (...) esta confusão generalizada evidencia uma identificação metodológica no que concerne à natureza e à 
operacionalização do projeto político-pedagógico no contexto escolar e sua necessária documentação (Garcia, 1999, p.27).

Além de verificarmos essa confusão generalizada de termos, observamos no desenvolvimento deste estudo que há um percentual importante de CEAs que responderam não dispor de PPP. Há outros que, embora tenham afirmado dispor de um PPP, apontaram para a necessidade de reformulá-lo, atualizá-lo. No item "Uma panorâmica dos CEAs no Brasil" serão apresentados e discutidos os dados levantados pelo presente estudo referentes a esta questão.

Entendemos que o PPP deva ser uma das dimensões iniciais a serem discutidas e equacionadas em qualquer projeto de implantação de CEA, por considerálo a espinha dorsal de qualquer CEA, representando toda a sua sustentação ideológica, política, pedagógica, metodológica e material, ou seja, um importante elemento estruturante do CEA e de uma diversidade de instituições. Sabemos, no entanto, que há diversas iniciativas que surgem sem qualquer discussão sobre seu PPP.

De fato, qualquer instituição que atua no campo do social e do cultural político, religioso, educacional, partidário, sindical... - e que pretende atuar com dignidade e eficácia no mundo atual, necessita manejar um instrumento composto de três partes (...):

- A proposta do que quer ajudar a alcançar como resultado social e de como quer ser (e precisa ser) para isso;

- A avaliação de até que ponto está contribuindo para o que quer alcançar e de até que ponto age como propôs em seu ideal;

- A proposta de ações, comportamentos e atitudes, regras, rotinas para um determinado período de tempo, a fim de tornar-se mais parecida com o ideal que escolheu.

- São duas "propostas" ambas necessárias, uma propondo o rumo, o horizonte, outra propondo caminhos, o que só será possível de maneira digna se as duas forem ligadas entre pela avaliação, pelo diagnóstico da prática (Gandin, 2000, p.18). 
O PPP de qualquer que seja a instituição deve ser construído tendo como ponto de partida as dimensões explicitadas na passagem anterior. Mas não só elas. Sabemos da necessidade de delineamento das duas "propostas" indicadas por Gadin (2000), a dos rumos e a do caminho, e suas ligações, mas compreendemos também que existem outras dimensões inerentes ao PPP sintonizados na perspectiva de educação e de educação ambiental sinalizada por este trabalho.

É possível propor um "recorte" para visualizarmos duas esferas no âmbito de um PPP, quais sejam: uma macro-institucional e uma micro-institucional. A primeira refere-se à relação institucional CEA-sistema, e é a que compreende todas as relações que o CEA estabelece com o seu meio externo, de uma forma ampla; a segunda, é relativa à coordenação normativa das ações e das relações de poder entre os sujeitos da ação envolvidos na práxis do CEA. Como decorrência da articulação destes dois domínios de relações, constituem-se as conexões do CEA com a sociedade.

Trouxemos um elemento novo à discussão, o da sua relação macroinstitucional. A definição de tais relações, bem como o planejamento das suas estratégias de articulação institucional e social são fundamentais para a construção de um PPP.

Identificamos na literatura (Gadotti, 1998; Garcia, 1999; Padilha, 2002; Veiga, 2002) diversos princípios, objetivos e características norteadores do PPP:

- Qualidade formal e política;

- Gestão democrática;

- Igualdade de condições;

- Processo dialógico e participativo;

- Liberdade;

- Valorização da Equipe de Trabalho;

- Avaliação periódica;

- Reflexão sobre a prática contínua;

- Respeito e horizontalidade;

- Cooperação;

- Autonomia;

- Não neutralidade da educação;

- Complexidade; e

- Transversalidade. 
Tratam-se de conceitos densos e que conferem maior complexidade ao tema, à sua discussão, construção, implementação. Nosso objetivo aqui não é o de abordar cada um desses conceitos, mas apenas apresentar um cardápio de opções que a construção de um PPP representa. A partir da interação e do diálogo que cada um desses elementos promove, vai se percebendo a complexidade deste processo e a sua importância.

Se este cenário representa um campo mais abstrato, mais conceitual e subjetivo, vislumbramos com mais facilidade o campo prático, relativo ao "passo a passo" para a construção de um PPP. Este lado pragmático é importante, mas deve ser trabalhado conjuntamente com o outro, pois ambos se nutrem mutuamente e continuadamente.

Compreendemos que o eixo central desse campo prático, sua espinha dorsal, refere-se à estrutura básica referencial de um PPP, compreendendo seus tópicos essenciais. Segundo Padilha (2002, p.90-93) há, ao menos, nove itens indispensáveis que devem ser considerados na construção de PPPs, a partir dos quais propomos adaptações voltadas para a realidade dos CEAs no país, e entendemos que oito deles são essenciais para PPPs de CEAs:

1) Identificação do projeto: traz informações da instituição gestora do CEA, período de duração do projeto, número de pessoas da equipe, estimativa de públicos que o CEA pretende trabalhar;

2) Histórico e justificativa: registro do processo histórico do CEA e da construção de seu PPP; apresentação do PPP, seus marcos conceituais; a importância do PPP para o contexto do CEA, seu alcance e funções socioambientais;

3) Objetivos gerais e específicos: os primeiros vinculados ao contexto que o CEA (e sua instituição promotora e/ou gestora) estão inseridos; os específicos são desdobramentos desses, e melhor explicitam como o CEA pretende alcançar o que se propõe. Os objetivos (ambos) devem nascer do processo e não fora dele, são definidos com base nas diretrizes e prioridades do PPP, e estão interrelacionados com a práxis do CEA;

4) Metas: são mais concretas e mais exeqüíveis que os objetivos, devendo ser quantificadas (mensuráveis) e detalhadas quanto mais 
possível. Quando elas não são atingidas, devem-se verificar coletivamente quais as possíveis causas e levantar as ações anteriormente previstas que, eventualmente, ainda não foram concretizadas. As metas devem estar totalmente sintonizadas com os objetivos (gerais e específicos) do PPP;

5) Desenvolvimento Metodológico: para que os objetivos e metas sejam alcançados, determinadas metodologias (estratégias) têm de ser desenvolvidas na prática. Eles emergem da realidade e dizem respeito ao quê, ao como e em que tempo será feito. Trata-se também de prever a disponibilidade de meios (físicos, materiais, humanos e financeiros);

6) Recursos: entendidos aqui como sendo de natureza financeira, material e humana. Pode partir de um diagnóstico do que o CEA possui, do que será necessário adquirir para atingir os objetivos propostos e como será esta aquisição. Aqui também se deve planejar como o CEA pretende se auto-sustentar, e se isso não seja uma realidade, que se explicite qual o percurso para se alcançar essa meta. De fato, entendemos que a meta da auto-sustentação (do ponto de vista econômico) deva ser perseguida, ainda que na prática se perceba uma considerável distância dela;

7) Cronograma: pode ser parte integrante do desenvolvimento metodológico, uma vez que ele prevê a distribuição ordenada das ações ao longo do tempo, de acordo com as possibilidades de ação e a disponibilidade de recursos, cronologicamente situadas;

8) Avaliação: elemento essencial em qualquer processo educacional, a avaliação retrata um momento de verificação da concretização parcial ou total dos objetivos e metas. Para tanto, é necessária a definição de quais os instrumentos, as estratégias e os agentes de avaliação. A avaliação é fundamental para reorientar o CEA e suas ações, e deve ser um processo continuado, pautado na práxis cotidiana.

Concordamos com Menezes (1999) quando afirma que a construção de um PPP configura-se num processo específico de cada CEA, sendo idiossincrático. Embora encontremos caminhos comuns, eixos conceituais e elementos orientadores 
que fornecem concepções comuns de um PPP, o seu processo de construção é único e particular e não generalizável. Se este processo construtivo é mutável, dinâmico, é preciso que percebamos que o CEA também o é.

Se visualizamos a especificidade que é cada CEA e como decorrência seu PPP, percebemos também que há inúmeras dificuldades para se desenvolver um processo de delineamento, construção e implementação de um CEA.

"Não restam dúvidas de que articular, elaborar, construir projeto pedagógico próprio, implementá-lo e aperfeiçoá-lo constantemente, envolvendo de forma criativa e prazerosa os vários segmentos constitutivos da comunidade (...), com suas respectivas competências, num processo coletivo, é um grande desafio. E o é em razão da necessidade e das expectativas pela melhoria da qualidade dos serviços educacionais e dos resultados desses serviços" (Bussmann, 2002, p.48).

\subsubsection{Sobre tipologias de CEAs}

Encontramos na literatura brasileira da EA alguns trabalhos que se propuseram a categorizar suas correntes e concepções. Iniciaremos este tópico por eles, ressaltando a carência de estudos que tratem especificamente da temática dos CEAs no Brasil, o que nos leva à busca de referenciais teóricos que tratam especificamente desta questão da Espanha,.

Isabel Carvalho (2002) propôs algumas possíveis matrizes tipológicas para o que ela denomina como "educações ambientais", orientadas sobre duas diferentes orientações: EA comportamental e EA popular. Enquanto a primeira valoriza "o papel da educação como agente difusor de conhecimentos sobre o meio ambiente e indutor da mudança dos hábitos e comportamentos considerados predatórios, em hábitos e comportamentos, tidos como compatíveis com a preservação dos recursos naturais", a segunda compreende o processo educativo como um ato político, no sentido amplo, isto é, como prática social de formação de cidadania.(...) Assim o foco da EA popular não são os comportamentos, mas (...) se propõe a transformação das relações com o meio ambiente dentro de um projeto de construção de um novo ethos social, baseado em valores libertários, democráticos e solidários" (Carvalho, 2002, p.86-87). 
Muito próxima a esta proposta vislumbramos a classificação sugerida por Lima (2002), que considera que a EA tem três vertentes, sendo duas localizadas em pólos opostos - a conservadora e a emancipatória - e uma terceira decorrente dessas duas.

\begin{abstract}
"A primeira, de acordo com o próprio nome, se interessa pela conservação da atual estrutura social, com todas as suas características e valores econômicos, políticos, éticos e culturais. A polaridade emancipatória, ao contrário, define no compromisso de transformação da ordem social vigente, de renovação plural da sociedade e de sua relação com o meio ambiente. Propomos ainda uma terceira categoria, variante da polaridade conservadora, que denominamos de "conservadorismo dinâmico", caracterizado por um perfil reformista, superficial e reducionista (Lima, 2002, p.125).
\end{abstract}

Identificamos, também, a tipologia que Marcos Sorrentino propõe, a qual aponta para quatro tipos de fazeres educacionais voltados à questão ambiental: conservacionista; educação ao ar livre; gestão ambiental; e economia ecológica (Sorrentino, 2000). Há também uma importante revisão teórica sobre o assunto (Layrargues, 2002) que fornece diversas classificações tipológicas não só do campo da EA mas do ambientalismo brasileiro.

Ressaltamos que, no entanto, o objetivo deste item não é apresentar propostas tipológicas para a EA brasileira, mas sim esboçar um panorama de classificações tipológicas de CEAs, adotando trabalhos de referência da Espanha. Passemos então a elas.

Elaboramos a Tabela 2, a seguir, com o objetivo de organizar todas as informações levantadas em sete obras de referência, como trabalhos, artigos, conferências e diagnósticos (Pérez, 1995; Seminários Permanentes de Educación Ambiental, 1996; Pérez \& Cid, 1998; Rosado \& Aguilló, 1998; Tomé, 2000; Pazos, 2000 e Guia de Recursos em EA/CENEAM, 2001). 
Tabela 2. Principais critérios e classificações tipológicas de CEAs espanhóis

\begin{tabular}{lll}
\hline Obra / Autor / Ano & $\begin{array}{l}\text { Critérios adotados para } \\
\text { construir a tipologia }\end{array}$ & Classificação Tipológica proposta \\
\hline Evaluación de la & Nível de Impacto na & 1) Granja Escola \\
calidad educativa de & Comunidade & 2) Centros de Natureza \\
los equipamientos & Âmbito de Incidência & 3) Centros de Recepção e \\
ambientales, Pérez & Localização Geográfica & Interpretação da Natureza \\
(1995) & Infra-estrutura, Espaços & 4) Escolas-oficina de Meio Ambiente \\
& e Recursos & 5) Centros de Experimentação e \\
& Destinatários ${ }^{42}$ & Inovação Educativa \\
& Modalidade de Promoção & 6) Museus, Equipamentos Urbanos e \\
& e Gestão & Outros \\
Seminários & Destinatários & 1) Escolas da Natureza \\
Permanentes de & Programa Pedagógico & 2) Centros de Interpretação, Educação \\
Educación & Concepção de EA & e Divulgação \\
AmbientaL (1996) & Tipo e Duração das & 3) Granja Escola \\
& Atividades & 4) Campos de Aprendizagem/Centros \\
& Objetivos do CEA & de Experimentação/ Centros \\
& & Ambientais
\end{tabular}

\footnotetext{
${ }^{42}$ No Brasil o termo mais usualmente encontrado é Tipo de Público ou Público Atendido.
} 
Tabela 2. Principais critérios e classificações tipológicas de CEAs espanhóis

\begin{tabular}{|c|c|c|}
\hline Obra / Autor / Ano & $\begin{array}{l}\text { Critérios adotados para } \\
\text { construir a tipologia }\end{array}$ & Classificação Tipológica proposta \\
\hline $\begin{array}{l}\text { Diagnóstico de los } \\
\text { equipamientos de } \\
\text { educación } \\
\text { ambiental de } \\
\text { andaluzia / Rosado } \\
\text { \& Aguilló (1998) }\end{array}$ & $\begin{array}{l}\text { Infra-estrutura } \\
\text { Destinatários } \\
\text { Princípios Pedagógicos } \\
\text { Tipo de Atividades }\end{array}$ & $\begin{array}{l}\text { 1) Sala de Aula na Natureza } \\
\text { 2) Granja-Escola } \\
\text { 3) Outros }\end{array}$ \\
\hline $\begin{array}{l}\text { Memória de las } \\
\text { jornadas de ea - } \\
\text { pamplona / Pérez \& } \\
\text { Cid, o. (1998) }\end{array}$ & $\begin{array}{l}\text { Tipo e Duração das } \\
\text { Atividades }\end{array}$ & Não propõe classificação tipológica \\
\hline $\begin{array}{l}\text { Apúntate a la } \\
\text { Granja / Tomé. } \\
\text { (2000) }\end{array}$ & $\begin{array}{l}\text { Infra-estrutura } \\
\text { Destinatários } \\
\text { Programa Pedagógico } \\
\text { Localização } \\
\text { Temática de Ação }\end{array}$ & $\begin{array}{l}\text { 1) Albergues da Natureza } \\
\text { 2) Sala de Aula na Natureza } \\
\text { 3) Campo de Aprendizagem } \\
\text { 4) Centro de Estudos do Mar } \\
\text { 5) Centro de Interpretação } \\
\text { 6) Escola da Natureza } \\
\text { 7) Escola-oficina } \\
\text { 8) Granja-Escola } \\
\text { 9) Museu } \\
\text { 10) Plano Experiencial de Recuperação } \\
\text { de Povos Abandonados } \\
\text { 11) Parque Natural e/ou Nacional }\end{array}$ \\
\hline
\end{tabular}


Tabela 2. Principais critérios e classificações tipológicas de CEAs espanhóis

\begin{tabular}{lll}
\hline Obra / Autor / Ano & $\begin{array}{l}\text { Critérios adotados para } \\
\text { construir a tipologia }\end{array}$ & Classificação Tipológica proposta \\
\hline Guia de Recursos & & 1) Sala de Aula na Natureza \\
en EA / CENEAM & & 2) Sala de Aula Urbana \\
$(2001)$ & & 3) Centro de Informação \\
& & 4) Centro de Interpretação \\
& & 5) Centro de Educação Ambiental \\
& & 6) Granja-Escola \\
& 7) Outros \\
Recursos e & Localização & 1) Centros e Equipamentos \\
Equipamentos de & Promotores & 2) Itinerários \\
EA.../ Pazos (2001) & Tipo de Atividades & 3) Museus, Parques e Equipamentos \\
& Destinatários & Culturais \\
& & 4) Outros \\
\hline
\end{tabular}

A observação da tabela suscita algumas reflexões importantes que auxiliam no processo de delineamento de propostas de classificações tipológicas para CEAs no Brasil. A coluna dois - Critérios adotados para construir a tipologia -fornece-nos uma gama de critérios que orientam processos de tipologização. Numa análise mais criteriosa desta coluna identificamos os critérios mais recorrentes e que, certamente, podem servir de parâmetro para a construção de uma classificação tipológica que englobe CEAs brasileiros:

- Tipo de Atividades;

- Público Atendido;

- Infra-estrutura;

- Localização do CEA; e

- Instituições Promotoras e Gestoras.

No que diz respeito à coluna 3, relativa às Classificações propostas, observa-se que dentre todos os "tipos" apontados, os mais freqüentes são:

- Granja Escola; 
- Museu;

- Centro de Interpretação;

- Sala de Aula na Natureza ${ }^{43}$;

- Equipamentos Urbanos; e

- Outros

"Uma análise mais atenta nessas seis classes recorrentes na literatura espanhola indica uma acentuada tendência a CEA inseridos numa perspectiva "naturalista" de EA, compreendendo que, pelo menos a metade delas tem essa vocação (Museu, Centro de Interpretação e Sala de Aula na Natureza). As demais (Granja Escola, Equipamentos Urbanos e Outros) constituem uma gama de iniciativas bem distintas uma das outras. Cabe ressaltar ainda, que na classe "Outros" há também iniciativas de vocação naturalista, como Albergues da Natureza e Acampamentos" (Seminários Permanentes de EA, 1996).

Apresentaremos, na Tabela 3, as principais características de cada uma das sete classes mais freqüentes de CEAs na Espanha, adotando como base os trabalhos já mencionados.

Tabela 3. Características principais das distintas "tendências" de CEAs espanhóis

\begin{tabular}{cl}
\hline Tendências dos CEAs & \multicolumn{1}{c}{ Características Principais } \\
\hline Granja Escola & $\begin{array}{l}\text { Instalações localizadas no meio rural, promovem contato direto } \\
\text { com o ambiente. Presença de animais e cultivos. Desenvolvem } \\
\text { atividades de um ou mais dias, mais voltadas ao público escolar. }\end{array}$ \\
Museu & $\begin{array}{l}\text { Visitas de menos de um dia. Oferece itinerários, exposições, } \\
\text { acesso a informações. Podem estar localizados em áreas } \\
\text { urbanas e "naturais". Atende um público variado. }\end{array}$
\end{tabular}

\footnotetext{
${ }^{43}$ O termo em castelhano é "Aulas de Naturaleza".
} 
Tabela 3. Características principais das distintas "tendências" de CEAs espanhóis

\begin{tabular}{|c|c|}
\hline Tendências dos CEAs & Características Principais \\
\hline Centro de Interpretação & $\begin{array}{l}\text { Localizados em áreas naturais protegidas, oferece atividades de } \\
\text { interpretação da natureza, de curta duração, a diversos públicos. }\end{array}$ \\
\hline $\begin{array}{l}\text { Sala de Aula na } \\
\text { Natureza }\end{array}$ & $\begin{array}{l}\text { Vocação naturalista destinado exclusivamente ao público } \\
\text { escolar. Em geral não estão localizados em áreas naturais } \\
\text { protegidos. }\end{array}$ \\
\hline Equipamentos Urbanos & $\begin{array}{l}\text { De diversos tipos, mais voltados para o âmbito da divulgação e } \\
\text { informação, podendo realizar atividades culturais. }\end{array}$ \\
\hline Outros & $\begin{array}{l}\text { Diversas iniciativas, como: Albergues da Natureza, } \\
\text { Acampamentos, Itinerários, Povoados-Escolas, etc. }\end{array}$ \\
\hline
\end{tabular}

Uma das principais reflexões que suscita esta revisão refere-se à dificuldade de se construir propostas de classificações tipológicas sem que possa haver distorções e inadequações práticas, uma vez que a temática é complexa e dificulta categorizações isentas de incoerências. Elas, por sua vez, esforçam-se por esboçar um panorama da diversidade de classes, tipos, vocações que CEAs apresentam, e contribuem para clarificar uma compreensão expandida da temática em questão.

Todo o leque de informações levantadas possibilita-nos avançar com um pouco mais de segurança no que diz respeito à proposição de classificações tipológicas para CEAs brasileiros, considerando que se trata de um processo em construção e que seus resultados não têm a pretensão de ser propostas acabadas e sem a necessidade de discussões mais aprofundadas.

Foi de fundamental relevância a revisão de literatura espanhola, através do qual foi possível identificar "atalhos" nas duras trilhas da tipologização, contribuindo para encurtar caminhos, minimizar obstáculos, potencializar esforços e sobretudo para facilitar a "largada", com a clareza necessária de que "o caminho se faz ao caminhar" (Machado, 1973, p.158). 


\section{METODOLOGIA}

Este capítulo apresenta e descreve o "passo a passo" da pesquisa, bem como todos os "insumos" que a mesma demandou ao longo da sua "caminhada". Uma caminhada rumo ao "problema" da pesquisa, o qual foi sendo desvelado à medida que novos fatos, experiências e reflexões eram suscitados.

De fato, compartilhávamos de um receio recorrente nos campos da pesquisa em Educação Ambiental, relativo ao "medo de não ter o problema plenamente delimitado no projeto de pesquisa inicial. Neste caso, é interessante lembrar que o projeto primeiro acaba passando por inúmeras transformações, e vários pesquisadores só conseguem definir o problema com maior clareza ao final da pesquisa" (Fazenda, 2001, p.17).

Descreveremos, a seguir, as técnicas e os instrumentos utilizados para o desenvolvimento de todas as fases da pesquisa: de preparação para coleta de dados; do levantamento de informações e da coleta em si; da análise do material levantado. Entendemos que, apesar de adotarmos determinado conjunto de técnicas, todo o caminho metodológico seguido teve que ser reinventado, descoberto, criado de forma incremental e articulada permanentemente. E, embora a literatura seja de fundamental importância nesse processo, ela não fornece respostas fechadas e prontas, apontando apenas possibilidades e diretrizes a seguir para a construção do caminhar de cada pesquisador, em cada pesquisa e naquele determinado espaço de tempo. Compreendemos pesquisa como sendo "uma atividade de investigação capaz de oferecer (e, portanto, produzir) um conhecimento novo a respeito de uma área ou de um fenômeno, sistematizando-o em relação ao que já se sabe a respeito dela(e)" (Luna, 2001, p.26).

Cabe ressaltar que pesquisar temas pouco explorados constitui tarefa revestida de consideráveis dificuldades. Como vimos no capítulo anterior, há carência de estudos sobre a temática dos Centros de Educação Ambiental no Brasil, a despeito de 
o campo da Educação Ambiental apresentar, atualmente, um acúmulo teórico e prático já considerável. Assim, diante de uma área tão pouco estudada e tão pouco conhecida, entendemos que uma técnica metodológica essencial é a da descrição.

"O mérito principal de uma descrição não é sempre a sua exatidão ou seus pormenores, mas a capacidade que ela possa ter de criar uma reprodução tão clara quanto possível para o leitor da descrição. Poderá haver tantas descrições de uma mesma coisa quantas sejam as pessoas especialistas que vejam essa mesma coisa" (Martins, 2001, p.56).

Em nosso caso, além de estarmos buscando levantar as características principais do "objeto" desta pesquisa para subsidiar e viabilizar a construção deste "retrato", foi preciso também trabalharmos no aprimoramento deste olhar, ou seja, no ajustamento da ótica que permitiu-nos vislumbrar de forma mais nítida e focada o "objeto" ao longo do estudo. Qualquer descrição, como elemento potencializador de processos educacionais, é portanto, uma ação não neutra e que reflete claramente o quê e onde se pretende chegar com e através dela.

O fato de relatarmos questões referentes à temática dos CEAs no país, traz consigo um campo de reflexões, concepções, visões, sobre o que se descreve, estando esta, portanto, numa relação direta com determinada concepção/tendência de CEA e de EA, ambas já explicitadas em momentos anteriores deste trabalho. Não há dúvida de que elas não só orientaram, quanto foram fundamentais na concepção, execução, sistematização, análise, avaliação e construção deste trabalho.

\subsection{Técnicas e instrumentos}

A seguir, descreveremos as técnicas e os instrumentos utilizados neste estudo, quais sejam: questionários, análise documental, momentos da Rede CEAs, tabulação e análise dos dados, bem como o processo de tipologização. 


\subsubsection{Questionários}

Como a proposta deste estudo era mapear o maior número de iniciativas de CEAs localizadas nas mais diversas regiões do país, a adoção de questionário como instrumento de coleta de dados foi de suma importância. Sabemos das suas limitações, que vão desde o fator tempo, até o baixo potencial de retorno (por volta de 15\%) e, dentre elas, há uma que merece ser considerada e refletida e que se relaciona à fidedignidade das informações levantadas por esse tipo de instrumento, especialmente quando realiza-se à distância (utilizando-se os serviços de correio).

Concordamos com Luna (2001) que afirma existirem, ao menos, três requisitos para o delineamento e o desenvolvimento de uma pesquisa, que são:

- a existência de uma pergunta que se deseja responder;

- a elaboração (e sua descrição) de um conjunto de passos que permitam obter a informação necessária para respondê-la;

- a indicação do grau de confiabilidade na resposta obtida (Luna, 2001, p.27).

O primeiro requisito foi abordado em capítulo inicial deste trabalho; o segundo refere-se, justamente, à metodologia da pesquisa; e o terceiro remete-nos a pensar na qualidade das informações e dados levantados e gerados, ou seja, no seu grau de confiança ao indicar uma dada realidade. Esta questão leva-nos a refletir sobre a adoção (ou não) do questionário para determinados tipos de estudos.

Como esta pesquisa focou-se, desde o início, na realização de um ousado mapeamento de iniciativas de CEAs no Brasil, adotamos uma estratégia de diagnóstico que pudesse organizar o maior número de informações e dados, da mais ampla amostra possível. A partir deste conjunto de referenciais tornar-se-ia, então, mais consistente a busca por elementos que viessem a contribuir para a construção de respostas aos problemas focais da mesma.

Em se tratando de uma temática pouco conhecida, em termos teóricos e práticos, a opção pelo instrumento questionário foi, aos poucos, adquirindo argumentos favoráveis. Algumas questões fundamentais tornaram-se facilidades na condução metodológica desta pesquisa, especialmente no que diz respeito à adoção e utilização 
do questionário como principal meio de levantamento e coleta de informações e dados, quais sejam:

- Disponibilidade de bancos de dados, listagens, levantamentos, de instituições atuantes no campo do ambientalismo e da educação ambiental $^{44}$;

- Relação custo/potencial de levantamento de informações;

- Amostra numerosa e bem dispersa em termos geográficos;

- Disponibilidade de tempo no levantamento dos dados (até um ano); e

- Possibilidade de obtenção de dados quantitativos e qualitativos.

Além destas questões, verificamos que a adoção do questionário como instrumento de coleta de dados vem sendo utilizado na Espanha há mais tempo (Pérez, 1995; Diagnóstico de Los Equipamientos de Educación Ambiental en Andalucía, 1997 e CENEAM, 2001), não sendo observado qualquer problema quanto à sua eficácia.

Os questionários foram organizados sob a forma de kits (Anexo A), de acordo com o processo de preparação descrito a seguir:

\section{A - Preparação dos kits}

Cada kit era composto de:

- Questionários 1 e 2;

- Carta Explicativa; e

- Envelope não selado para resposta ${ }^{45}$

Inicialmente pretendíamos construir um único questionário que possibilitasse o levantamento de todas as informações necessárias para o desenvolvimento deste estudo. No entanto, quando o processo de elaboração do mesmo foi iniciado, constatou-se que existiam dois campos distintos de informações desejadas:

\footnotetext{
${ }^{44}$ Veremos adiante que para a construção da amostra para coleta de informações adotamos como obra central a Ecolista (Pizzi, 1996). Destacamos, no entanto, outras referências importantes: base de dados do SIBEA - Sistema Brasileiro de Informações de Educação Ambiental, acessível através da página: http://www.mma.gov.br; base de dados do BDT - Base de Dados da Terra, http://www.bdt.org.br; banco de dados de diversas redes estaduais de educação ambiental além de diversos contatos na própria Rede Brasileira de EA - REBEA; dentre diversas outras.

${ }^{45}$ Não foram encaminhados envelopes selados por falta de recursos, estimado em cerca de $\mathrm{R} \$ 450,00$ (em agosto de 2002).
} 
quantitativas e qualitativas. Desta forma, optamos pela construção de dois questionários: um focando no primeiro campo, ou seja, o quantitativo e o outro com uma abordagem bem mais qualitativa. Por uma questão didática, preferimos a separação dos mesmos e os denominamos de: Questionário 1, de âmbito quantitativo e Questionário 2, qualitativo.

Adotamos como referências para a construção de ambos questionários, dois trabalhos - Silva (2001) e CENEAM (2001) - os quais utilizaram instrumento semelhante no levantamento de dados de CEAs, respectivamente no Brasil e na Espanha. O segundo, trata-se de um trabalho continuado que o Centro Nacional de Educação Ambiental da Espanha realiza junto aos CEAs daquele país, resultando na construção e na atualização de softwares ${ }^{46}$.

O questionário 1 foi organizado em seis partes principais:

1) Dados do CEA: informações gerais, localização, ano de início, contatos, instituição promotora e gestora, época e horários de funcionamento;

2) Edifício, Intra-Estrutura e Recursos: características da sede, dos espaços, dos recursos e dos equipamentos disponíveis, do entorno;

3) Público Atendido: quem é (são), como "chegam" ao CEA, estatísticas de visitação;

4) Equipe Pedagógica: quantidade, formações, voluntariado;

5) Atividades Desenvolvidas: intervenções e combinações mais freqüentes; duração, temas trabalhados, formas de pagamento;

6) Espaço para Avaliação do Questionário: comentários e críticas sobre o questionário.

O questionário 2 foi elaborado com o objetivo de coletar elementos que pudessem complementar e qualificar as informações obtidas pelo questionário anterior. Ele foi organizado com oito questões, as quais referiam-se basicamente à dimensão do Projeto Político-Pedagógico.

\footnotetext{
${ }^{46}$ As versões anteriores a 2000 eram encontram-se disponíveis em disquete e a última em CD-ROM. No site: http://www.mma.es/ceneam é possível acessar um formulário de atualização de dados de CEAs já cadastrados, bem como inserir novos registros de CEAs. Periodicamente o CENEAM organiza uma nova versão deste Guia, em CD-ROM.
} 
No questionário, entretanto, optou-se pela utilização da denominação Programa Pedagógico, por ser mais facilmente entendível no meio. Este questionário, então, abordou questões como o Histórico do CEA, seus Objetivos principais, suas Estratégias de Avaliação, Concepções sobre Biodiversidade, Principais Dificuldades e Perspectivas, além de um campo para Avaliação do questionário (semelhante ao anterior).

Antes do envio dos questionários, realizou-se um pré-teste, buscando avaliar este instrumento e readequá-lo para posterior envio. O teste foi feito no dia 04/02/2002 junto ao Museu da Água, um Centro de Educação Ambiental localizado no município de Piracicaba - SP. Pela proximidade e facilidade de acesso, este CEA foi escolhido para a realização do pré-teste. Este foi feito pessoalmente e a leitura das questões era feita seguindo fielmente o texto contido nos questionários.

A técnica do pré-teste demonstrou-se muito importante para a avaliação e o incremento de ambos os questionários, sobretudo pela inclusão de itens em algumas questões, o que os tornaram mais compreensíveis, mais completos e melhor apresentáveis.

Para orientar o envio dos questionários construiu-se uma base de dados, denominada Listagem Amostral, contendo 500 instituições selecionadas para o envio dos kits. Esta Listagem Amostral foi elaborada a partir de uma obra de referência (Pizzi, 1996) e incrementada com contatos de CEAs e iniciativas de EA relacionadas à temática dos CEAs já conhecidas (pessoalmente, através de outros estudos já realizados, por meio de indicações de profissionais da área e pela internet). Foi feita uma seleção de instituições ambientalistas contidas na ECOLISTA, constituída uma pré-listagem a qual foi incrementada com os contatos de iniciativas de EA e de CEAs já conhecidas e mapeadas e originou a Listagem Amostral, que foi esquematicamente organizada da seguinte forma:

1. CEAs: correspondente àquelas iniciativas que já tínhamos absoluta certeza de que "existiam" de fato, mas não tínhamos plena certeza de que se encontravam atuantes no momento dessa pesquisa.

\section{Empresas Públicas e Privadas:}

2.1 do setor florestal

2.2 do setor minerador

2.3 do setor energético e de saneamento 


\section{ONGs}

\section{Universidades Públicas e Privadas}

\section{5. Órgãos Públicos:}

5.1 Federais (Unidades de Conservação, IBAMA, MMA, etc)

5.2 Estaduais (Secretarias Estaduais de Meio Ambiente, Instituto Florestal, Núcleos de E.A. do Estado de SP, Unidades de Conservação, Fundações)

5.3 Municipais (Prefeituras, Secretarias de Meio Ambiente e da Educação, Jardins Botânicos, Zoológicos, Parques Municipais, etc).

Tabela 4. Como foi distribuída a amostra

\begin{tabular}{lcc}
\hline \multicolumn{1}{c}{ Componente da Listagem Amostral } & Quantidade de Kits enviados & $\%$ \\
\hline 1) CEAs & 88 & 17,6 \\
2) Empresas Públicas e Privadas (total) & 47 & 9,4 \\
2.1) Empresas do setor florestal & 11 & 2,2 \\
2.2) Empresas do setor minerador & 8 & 1,6 \\
2.3) Empresas do setor de energético de de & 28 & 5,6 \\
saneamento & & \\
3) ONGs & 156 & 31,2 \\
4) Universidades Públicas e Privadas & 55 & 11 \\
5) Órgãos Públicos (total) & 154 & 30,8 \\
5.1) Federais & 26 & 5,2 \\
5.2) Estaduais & 97 & 19,4 \\
5.3) Municipais & 31 & 6,2 \\
TOTAL & 500 & 100 \\
\hline
\end{tabular}

É preciso explicar que, na Tabela 4, as porcentagens altas relativas às categorias "órgãos públicos" e "ONGs" (30,8\% e 31,2\% respectivamente, totalizando $62 \%$ da amostra) trata-se de um instrumento de equalização da amostra em relação a todas as regiões do país. Constatou-se nas regiões Norte e Centro-Oeste as menores disponibilidades de instituições que atuassem no campo da educação ambiental, sendo que a sua grande maioria refere-se, justamente, às categorias supracitadas, ou seja, "órgãos públicos" e "ONGs". 


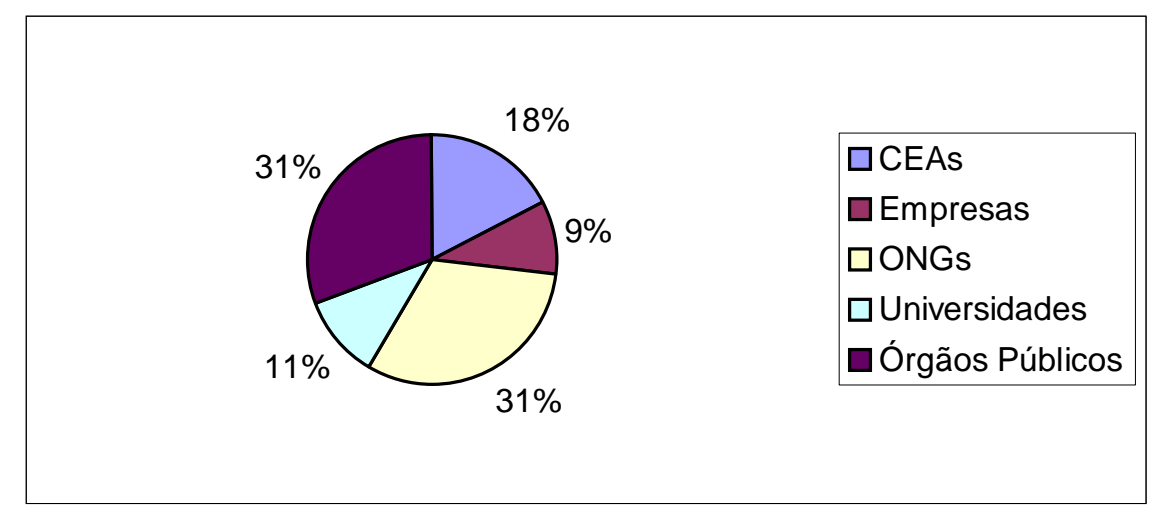

Figura 3 - Distribuição das instituições na Listagem Amostral

Observando as Tabela 4 e Figura 3 é possível, ainda, discutir o percentual relativo à classe "órgãos públicos estaduais" que foi de 19,4\% (correspondendo a mais da metade do total da categoria "órgãos públicos"). Isto se deu pelo fato de serem incluídas na Listagem Amostral diversas Unidades de Conservação do Estado de São Paulo que são de incumbência do Instituto Florestal, dentre elas: Parques Estaduais, Jardim Botânicos e Estações Ecológicas.

\section{B - Envio dos kits}

Foram enviados 500 kits no início de setembro de 2002 a todas as instituições contidas na Listagem Amostral, divididas nas seguintes categorias:

- aquelas que certamente sabíamos que possuíam Centros de Educação Ambiental, pela investigação de informações na Internet, na literatura, em jornais, TV, etc; através de contato com as próprias instituições, intercâmbio entre profissionais da área (em congressos, eventos, no cotidiano, pela universidade, no campo);

- aquelas que possivelmente dispunham de CEAs - foram feitas amostragens de diversas instituições, dentre elas: empresas que, por exemplo, possuíam setores de Meio Ambiente e que realizam algum tipo de atividade de "educação ambiental" mas que, em princípio, não dispunham de CEAs; ONGs que atuavam no campo da E.A., mas não tínhamos absoluta clareza se eram CEAs (segundo a concepção proposta nesta dissertação); Universidades que dispunham de Laboratórios de Educação 
Ambiental e de outros setores de campos afins (Biologia, Ecologia, Formação Ambiental, Informação Ambiental, etc).

Tabela 5. Distribuição dos kits remetidos por Unidades da Federação

\begin{tabular}{ccc}
\hline Unidade Federativa & Número de Kits enviados & \% do total enviado \\
\hline São Paulo & 139 & 27,8 \\
Minas Gerais & 60 & 12 \\
Rio de Janeiro & 33 & 6,6 \\
Paraná & 30 & 6 \\
Bahia & 23 & 4,6 \\
Goiás & 22 & 4,4 \\
Rio Grande do Sul & 22 & 4,4 \\
Santa Catarina & 22 & 4,4 \\
Distrito Federal & 16 & 3,2 \\
Espírito Santo & 14 & 2,8 \\
Pernambuco & 14 & 2,8 \\
Mato Grosso & 11 & 2,2 \\
Ceará & 10 & 2 \\
Pará & 10 & 2 \\
Paraíba & 10 & 2 \\
Amazonas & 9 & 1,8 \\
Piauí & 9 & 1,8 \\
Mato Grosso do Sul & 7 & 1,4 \\
Rondônia & 7 & 1,4 \\
Tocantins & 7 & 1,4 \\
Acre & 5 & 1 \\
Maranhão & 5 & 0,8 \\
Alagoas & 4 & 0,8 \\
Sergipe & 2 & 0,4 \\
Amapá & 500 & 100 \\
Roraima & & \\
TOTAL & 2 & 1 \\
& 5 & 2 \\
\hline
\end{tabular}


A simples observação das Tabelas 5 e 6 indica a desproporcionalidade entre a distribuição de instituições ambientalistas, mais especificamente daquelas potencialmente ligadas à temática dos CEAs no país. Observa-se que a Região Sudeste concentrou praticamente a metade dos kits enviados, sendo pouco mais da metade destes provenientes do Estado de São Paulo (argumento já apontado). Por meio da distribuição geográfica da Listagem Amostral já era possível construir a hipótese de que havia considerável desigualdade na distribuição destas iniciativas pelo país e que elas apontavam para um determinado padrão de distribuição, acompanhando o chamado "eixo do desenvolvimento" do país. Discutiremos essa questão mais adiante, no item "Uma panorâmica dos CEAs no Brasil".

Tabela 6. Distribuição dos kits remetidos por Região

\begin{tabular}{|c|c|c|c|}
\hline Região & 7) & $\begin{array}{l}\text { Número de Kits } \\
\text { enviados }\end{array}$ & $\%$ do total enviado \\
\hline Sudeste & & 246 & 49,2 \\
\hline Nordeste & & 82 & 16,4 \\
\hline Sul & & 74 & 14,8 \\
\hline Centro Oeste & & 56 & 11,2 \\
\hline Norte & & 42 & 8,4 \\
\hline TOTAL & & 500 & 100 \\
\hline
\end{tabular}

\section{C - Retorno}

Dez dias após o envio - meados de setembro de 2002 - já retornavam questionários respondidos, majoritariamente por correio e uma minoria pela internet (via e-mail). Embora os questionários somente tivessem sido enviados pelo correio (de forma impressa), algumas instituições, assim que os receberam, entraram em contato solicitando o envio destes materiais por meio eletrônico (e-mail).

Os questionários foram recebidos até o final de 2003, quando se iniciou o processo de tabulação, interpretação e análise dos dados. O volume de retorno foi mais efetivo no período de cinco meses após o envio, ou seja, de setembro de 2002 a 
fevereiro de 2003, embora alguns ainda retornaram até o segundo semestre de 2003. Cabe ressaltar que diversos outros CEAs que receberam os kits manifestaram-se quanto ao interesse em colaborar com a pesquisa, mas não retornaram os questionários até o início de 2004, alegando, sobretudo, falta de tempo para preenchimento.

Tabela 7. Distribuição dos kits retornados por Unidades da Federação

\begin{tabular}{|c|c|c|}
\hline Unidade da Federação & $\mathrm{N}^{0}$ de kits retornados & $\%$ de retorno \\
\hline São Paulo & 25 & 17,9 \\
\hline Espírito Santo & 13 & 92,8 \\
\hline Paraná & 11 & 36,6 \\
\hline Minas Gerais & 10 & 16,6 \\
\hline Rio de Janeiro & 7 & 21,2 \\
\hline Goiás & 5 & 22,7 \\
\hline Rio Grande do Sul & 5 & 22,7 \\
\hline Bahia & 3 & 13 \\
\hline Santa Catarina & 3 & 13,6 \\
\hline Distrito Federal & 3 & 18,7 \\
\hline Pernambuco & 2 & 14,2 \\
\hline Ceará & 2 & 20 \\
\hline Paraíba & 2 & 20 \\
\hline Mato Grosso & 1 & 9,1 \\
\hline Pará & 1 & 10 \\
\hline Amazonas & 1 & 11,1 \\
\hline Piauí & 1 & 11,1 \\
\hline Mato Grosso do Sul & 1 & 14,2 \\
\hline Tocantins & 1 & 14,2 \\
\hline Acre & 1 & 20 \\
\hline Maranhão & 1 & 20 \\
\hline Rio Grande do Norte & 1 & 25 \\
\hline Sergipe & 1 & 33,3 \\
\hline Rondônia & 0 & - \\
\hline Alagoas & 0 & - \\
\hline Amapá & 0 & - \\
\hline
\end{tabular}


Tabela 7. Distribuição dos kits retornados por Unidades da Federação

\begin{tabular}{ccc}
\hline Unidade da Federação & $\mathrm{N}^{0}$ de kits retornados & $\%$ de retorno \\
\hline Roraima & 0 & - \\
TOTAL & 101 & - \\
\hline
\end{tabular}

Comparando a Tabela 5 com a 7 relativas, respectivamente, ao envio e retorno dos materiais, verifica-se que há certa correlação entre os Estados que receberam poucos kits e que retornaram os questionários preenchidos. Os Estados do Acre, Maranhão, Alagoas, Rio Grande do Norte, Sergipe, Roraima e Amapá foram os que menos receberam kits, sendo que a soma chega a marca de $5 \%$ do total de kits enviados a todos as Unidades Federativas do país. Destes Estados, três (Alagoas, Amapá e Roraima) tiveram um taxa de retorno de zero, além do Estado de Rondônia.

A Tabela 7 (coluna 3) traz-nos um dado importante que merece ser discutido. Além destes quatro Estados ( $A L, R R, A P$ e $R O)$ que não tiveram nenhum questionário de CEA retornado, tivemos mais quatro Estados que alcançaram taxas relativamente baixas de retorno (em relação a quantidade de kits enviados), respectivamente: Mato Grosso (9,1\%), Pará (10\%), Amazonas e Piauí (ambos com 11,1\%).

Tabela 8. Distribuição dos kits retornados por Região

\begin{tabular}{ccc}
\hline Região & Número de Kits retornados & \% de retorno \\
\hline Sudeste & 55 & 22,3 \\
Sul & 19 & 25,6 \\
Nordeste & 13 & 15,8 \\
Centro Oeste & 10 & 17,85 \\
Norte & 4 & 9,5 \\
TOTAL & 101 & - \\
\hline
\end{tabular}

Por outro lado, merece destaque a marca obtida por alguns Estados, com a melhor taxa de retorno. Em especial o Estado do Espírito Santo, que alcançou a marca de $92,8 \%$ de retorno, sendo a melhor delas, seguida pelos Estados do Paraná, com $36,6 \%$ e Sergipe, com 33,3\%. Esta marca obtida pelo Espírito Santo (92,8\%) pode ser 
facilmente compreendida. Dos catorze kits enviados ao Estado (Tabela 5) treze retornaram (Tabela 7) porém, destes treze, oito referem-se a CEAs de uma mesma instituição, qual seja, da prefeitura municipal de Vitória, que dispõe de oito CEAs localizados nos diversos parques urbanos do município. Na Listagem Amostral, no entanto, não foram consideradas estas oitos iniciativas, mas somente uma única - a prefeitura municipal de Vitória, como sendo a instituição promotora e gestora dos CEAs. Também não se sabia da existência deste número de CEAs sob a responsabilidade da prefeitura. Isto pode explicar a alta taxa de retorno de questionários do Estado (92,8\%). Cabe ainda ressaltar que a prefeitura providenciou fotocópias dos questionários enviados, encaminhando-os aos oito CEAs localizados no município e sob sua tutela.

\subsubsection{Análise documental}

Juntamente ao envio dos kits era solicitado que o CEA enviasse, se possível, exemplares de materiais de produção própria, visando subsidiar a pesquisa. Simultaneamente, ao longo dos anos de 2002 e 2003, foi realizado um continuado processo de coleta de materiais sobre a temática, sobretudo a partir de encontros, congressos e eventos em geral da área e afins; participação em reuniões de redes; e de contatos e acessos a materiais via internet (sites e e-mails).

O resultado alcançado foi consideravelmente positivo, e pode ser observado na Tabela a seguir.

Tabela 9. Materiais produzidos por CEAs

\begin{tabular}{lcc}
\hline \multicolumn{1}{c}{ Tipos de Materiais } & $\mathrm{N}^{\mathrm{OS}}$ absolutos & \% do total coletado \\
\hline Folders/Folhetos & 33 & 39,3 \\
De Divulgação (adesivos, jornais, marcadores de & 22 & 26,3 \\
página, panfletos, p/ colorir) & & \\
Livretos, Anais & 9 & 10,7 \\
Cartilhas & 8 & 9,6 \\
Projetos/Programas Pedagógicos & 7 & 8,3 \\
Pastas Institucionais & 3 & 3,5
\end{tabular}


Tabela 9. Materiais produzidos por CEAs

\begin{tabular}{cccc}
\hline & Tipos de Materiais & $\mathrm{N}^{\text {os }}$ absolutos & \% do total coletado \\
\hline Cartazes & TOTAL & 2 & 2,3 \\
& & 84 & 100 \\
\hline
\end{tabular}

O processo de análise deste material foi concebido tendo como importante referencial o estudo feito pelo Instituto Ecoar para a Cidadania (Trajber \& Manzochi, 1996), o primeiro da série "Avaliando", o qual avança na análise de materiais impressos, levantando questões e reflexões acerca dos conteúdos ali presentes, e que concepções e visões de EA eles traziam consigo. A partir desta referência, buscou-se definir dois princípios chaves para que este estudo pudesse, a partir deles, proceder a uma breve análise dos materiais de CEAs levantados.

No decorrer da revisão teórica buscamos fundamentar a escolha pela adoção dos princípios da participação dialógica não só na implementação desta tarefa, como também em todo o processo de desenvolvimento deste estudo. No que diz respeito ao processo de análise dos materiais impressos dos CEAs, procurou-se identificar em cada um deles elementos que pudessem indicar o grau de sintonia do CEA com os princípios do diálogo e da participação. Para tanto, três pontos foram propostos a fim de facilitar a observação e análise do material:

a) Estrutura, espaços e equipamentos que o CEA dispõe;

b) Atividades que o CEA desenvolve; e

c) Princípios e conceitos orientadores.

Os dois primeiros pontos são mais focados em aspectos práticos do CEA, enquanto que o terceiro é de cunho mais conceitual, teórico. Em todos eles buscou-se focar em elementos que pudessem contribuir para responder a seguinte questão: "Até que ponto espaços, estruturas, equipamentos, atividades e princípios contribuem/facilitam/provocam processos educacionais dialógicos e participativos nestes CEAs?". Ressalta-se que há uma "leitura" do conceito de participação como sendo aquele que:

a) Propicia condições básicas de participação (espaços, tempo, etc);

b) Disponibiliza informações, apropriadas e contextualizadas à realidade e ao público; 
c) Concebe espaços/momentos de discussões, de socialização, de interlocução; e

d) Propicia condições de tomadas de decisão reais e efetivas.

Cabe salientar que se considera participação efetiva como senda aquela que pressupõe as quatro dimensões apontadas e não somente alguma(s) delas. Entendese que o conceito do diálogo é transversal dentro desta proposta, devendo estar presente em todas as suas dimensões.

Consideradas todas estas questões demos andamento ao processo de análise dos materiais, com vistas à viabilidade de categorizá-los segundo os dois princípioschave adotados. Dessa forma, foi possível construir três classes de CEAs :

1. Aqueles que dão mais ênfase à teoria, à transmissão de conhecimentos e de informações do que à prática - dotados de espaços, estruturas e atividades de vocações expositivas e informativas, com certa proximidade à corrente chamada "tradicional" da educação ${ }^{47}$;

2. Aqueles que, embora disponham de retórica ambiental, concentram seus esforços em atividades práticas, com vocação ativista. Dispõem de espaços e de atividades de contato com o ambiente, dinâmicas e vivências, com pouca conexão destas experiências com aspectos teórico-conceituais da questão ambiental;

3. Aqueles que conseguem equilibrar teoria e prática, desenvolvendo atividades de interação e de reflexão, de construção conjunta de ações com os públicos com os quais trabalha. Dispõem de estruturas e de atividades que estabelecem certa coerência com os conceitos e princípios que pregam, quais sejam: reflexão crítica da realidade, participação dialógica e emancipação.

Das três classes propostas, observou-se maior percentual de iniciativas no âmbito da primeira e menor percentual na classe número dois.

Este processo de análise dos materiais constituiu-se em atividade complementar a este estudo. Na medida em que se coletava uma série de materiais, das mais variadas vocações, percebeu-se que havia um bom potencial de estudo a ser explorado. No item "Uma panorâmica dos CEAs no Brasil" estaremos retomando

\footnotetext{
${ }^{47}$ Denominada por Paulo Freire de educação bancária.
} 
alguns elementos identificados nesta análise documental, visando subsidiar nossa discussão sobre a situação dos CEAs no Brasil. Cabe ainda salientar que se vislumbram neste campo importantes oportunidades para estudos e reflexões sintonizadas numa dimensão de âmbito comunicativo de CEAs brasileiros, abrindo importantes conexões com a teoria da ação comunicativa proposta por Habermas (1989).

Como veremos na seqüência, há neste trabalho, ainda que de maneira bastante tímida e parcial, certa convergência com esta teoria, especialmente quando o autor aponta o princípio da participação como sendo essencial em todo o processo por ele denominado como agir comunicativo. Este, já delimita que parte de uma concepção de comunicação completamente imbricada numa postura pró-ativa e performativa.

\subsubsection{Momentos da Rede CEAs}

\section{A - Encontros presenciais}

A Rede Brasileira de Centros de Educação Ambiental - Rede CEAs - emerge em 2002 a partir do mapeamento de iniciativas de CEAs pelo país - deflagrados de forma mais sistematizada a partir do envio/retorno dos questionários - e do início de uma articulação em nível nacional, alavancada a partir da intensificação de contatos entre CEAs. Através da inter-comunicação, troca de experiências e de olhares entre as distintas educações ambientais ${ }^{48}$ pensadas e praticadas nas também diversificadas propostas de CEAs. Se há, sem sombra de dúvidas, pluralidade nesse movimento, há também consideráveis singularidades, inerentes a esse conjunto de iniciativas que estamos denominando como Centros de Educação Ambiental (CEAs). Características estas que nos concedem subsídios para debruçarmos sobre esta temática com respeito, cautela e com uma boa dose de ousadia. Ser ousado no sentido de um espírito permanente pelo descobrimento e pela incessante busca pelo diálogo e pela construção de novos saberes, novos conhecimentos e novas experiências sobre a temática dos CEAs.

\footnotetext{
${ }^{48}$ Concordando e reforçando o que diversos autores do campo da EA apontam, dentre os quais mencionamos Isabel Carvalho e Philippe Layrargues.
} 
Mas afinal de contas o que são estes CEAs? O que fazem, pra quê e a quem servem e com que propósitos? Que virtudes eles têm e como potencializá-las? Quais são as principais dificuldades que eles enfrentam na atualidade, e quais as estratégias para superá-las?

Questões como essas (e outras) estavam colocadas (e permanecem) no momento da articulação da proposta de uma Rede que viesse a propiciar diversas ações integradas entre CEAs no Brasil. A proposta da Rede CEAs começa a ganhar concretude então, a partir de meados de 2002, mas cabe ressaltar que o processo estava sendo gestado há pelo menos um ano de antecedência.

Alguns elementos contribuíram para esse momento antecedente da Rede CEAs, alguns anteriormente mencionados, e que merecem ser retomados e destacados conjuntamente com os demais:

a) envolvimento da OCA - Laboratório de Educação e Política Ambiental da ESALQ/USP em pesquisas diagnósticas no campo dos CEAs, já a partir de 1999;

b) contato com publicações espanholas relativas à temática, o que possibilitou "beber" em um determinado campo de referenciais teóricos e práticos, até então, pouco diagnosticados e pouco conhecidos no Brasil (sobretudo a partir de 1999). Parte substancial destas obra constam nas "Referências Bibliográficas" deste trabalho;

c) intercâmbio de experiências e de pesquisa na Espanha, realizado em 2001, o que permitiu conhecer com mais profundidade iniciativas de CEAs; estabelecer contatos com especialistas e instituições referências deste campo ${ }^{49}$.

Se a proposta que emergia (e já previamente pensada) era a de deflagrar uma rede (em âmbito nacional) de CEAs, estavam pré-estabelecidas então alguns pressupostos essenciais:

\footnotetext{
${ }^{49} \mathrm{Em}$ alusão ao Centro Nacional de Educación Ambiental do Ministério do Meio Ambiente espanhol (http://www.mma.es/ceneam); e às pessoas: José Gutiérrez Pérez (Professor da Universidade de Granada - Andalucía); Pablo Ángel Meira Cartea (Professor da Universidade de Santiago de Compostela - Galícia); Oscar Cid (Diretor do Campo de Aprendizagem do Delta do Ebro - Catalunha); Araceli Serantes Pazos (Professora da Universidade de La Coruña - Galícia); e Paco Heras (Coordenador - CENEAM).
} 
a) partia-se de uma concepção de rede como sendo estratégia meio e não fim da ação, ou seja, o objetivo não era criar a rede e pronto, mas por meio dela tornar-se-ia mais fácil alcançar alguns objetivos originalmente previstos para ela;

b) objetivos preliminares: basicamente a proposta da Rede CEAs emergia a partir de alguns objetivos considerados essenciais para a construção de uma rede que viesse a articular estas iniciativas:

- contribuir para a inter-comunicação entre CEAs; troca de informações e de experiências, potencializando suas respectivas ações (como CEAs isolados e como um coletivo de CEAs). Para este objetivo propunha-se uma ação diagnóstica permanente e continuada, através do mapeamento e do levantamento de dados relativos às diversas iniciativas de CEAs em atividade no país;

- contribuir para reflexões aprofundadas sobre a temática dos CEAs no país, por meio de discussões, produção, sistematização e socialização de conhecimentos;

- contribuir para a divulgação de ações junto ao meio de educadores(as) ambientais do país, com especial destaque para os segmentos populacionais com os quais os CEAs têm se relacionado com mais freqüência, intencionando atingir a todo o conjunto da sociedade brasileira;

- estimular a discussão, o delineamento e a implementação de políticas públicas no campo da Educação Ambiental, especialmente o dos CEAs.

c) concepção de rede entendida como um processo de caráter incremental e articulado, que estimule e crie condições para propiciar um efetivo enraizamento das suas ações nas mais diversas regiões, realidades e localidades do país.

d) deflagrava-se um processo partindo-se de um conjunto de desafios que estavam então colocados - um pano de fundo bastante realista e certamente dialogando e aprendendo com os dez anos de trajetória da Rede Brasileira de Educação Ambiental - a REBEA. Para uma rede que inicia sua caminhada - a caçula das Redes de EA no país - mesmo antes dos seus primeiros passos concretos, já vislumbrava-se alguns desafios, os quais merecem ser destacados e rapidamente comentados. 
Estabelecidas estas considerações iniciais, podemos destacar dois encontros presenciais que contribuíram, substancialmente, para qualificar conceitos e questões levantadas e estudadas neste trabalho. Diversas ações nas quais a Rede esteve envolvida, como a viabilização e manutenção de uma página na internet e de uma lista de discussão; cadastramento de CEAs do país, e realizações de seus "elos" certamente contribuíram para sua disseminação, articulação e avanço. Faz-se necessário citar dois importantes desdobramentos do processo de surgimento da Rede CEAs que são:

- a criação de um Grupo de Trabalho "CEAs de empresas", em Minas Gerais ${ }^{50}$;

- a articulação em torno da temática no âmbito da Rede Rio de EA ${ }^{51}$

Com a clareza de estas duas ações são importantes realizações da e para a tessitura da Rede CEAs, não as detalharemos porque não é objetivo deste trabalho e como uma forma de estimulá-las a refletir, sistematizar e produzir conhecimentos de e a partir de suas próprias práticas, provocando também outras iniciativas, e desdobramentos espontâneos da rede a pensarem a respeito.

Conduzindo esta descrição/reflexão para a questão dos Momentos Presenciais da Rede, visualizamos claramente dois eventos que contribuíram efetivamente e sistematicamente para a evolução deste estudo, embora deixemos claro que a Rede não restringiu seus momentos de encontros presenciais somente a estes dois.

O primeiro deles foi o I Encontro Paulista de Centros de Educação Ambiental (EPCEAs) que foi realizado simultaneamente ao II Encontro Estadual de Educação Ambiental (EEEA), no município de Rio Claro em julho de 2003, por iniciativa da Rede Paulista de Educação Ambiental (REPEA) e da Rede CEAs. Neste encontro forma apresentadas questões relativas à temática dos CEAs, com o intuito de provocar o debate na platéia. Mas, a principal vantagem deste evento, do ponto de vista desta pesquisa, foi a qualificação que ele propiciou à proposta conceitual de Centro de Educação Ambiental. Até então, adotava-se uma proposta conceitual baseada em três

\footnotetext{
${ }^{50}$ Coordenado atualmente por Déborah Munhoz, educadora ambiental que atua no Núcleo Ambiental da $f$ Federação das Indústrias do Estado de Minas Gerais - FIEMG, a qual pode ser contatada através do seguinte endereço eletrônico: deborahm@fiemg.com.br.

${ }^{51}$ Coordenada por Jacqueline Guerreiro, educadora ambiental do Rio de Janeiro; endereço eletrônico: jguerreiro@alternex.com.br.
} 
dimensões essenciais: a) espaços, equipamentos e entorno; b) equipe educativa; c) projeto político-pedagógico. Durante as discussões emergiu uma quarta dimensão que, até então, era ignorada que é a da necessidade de elaboração de um Plano de Sustentabilidade para o CEA, o qual expusesse as estratégias implementadas para a busca da sua sustentabilidade, considerada em todas as suas dimensões (ambientais, econômicas, sociais, culturais, políticas, etc). E, de fato, esta foi a concepção de CEA que passamos a adotar neste estudo, alicerçada sobre quatro dimensões e não mais em três.

O segundo evento foi o Encontro Nacional de Centros de Educação Ambiental (ENCEA), realizado no município de Timóteo - MG, em outubro de 2003, sob organização da Rede CEAs, do CEA Oikós e da Fundação Acesita. Este encontro foi de fundamental relevância para a discussão de questões relativas à temática dos CEAs, sobretudo de âmbito prático (atividades, projetos e programas). Contribuiu, também, para a consolidação da proposta conceitual construída durante o Encontro Paulista de CEAs, ocorrido três meses antes deste. Do Encontro Nacional resultou um documento denominado "Carta de Timóteo", o qual foi construído a posteriori, seguindo as deliberações e colocações que emergiram no evento. Trata-se de um documento consideravelmente relevante para a temática dos CEAs no país (Anexo B).

Em ambos encontros a Rede CEAs avançou na sua intenção de estimular o surgimento de novos "elos" e "nós", discutindo sua proposta e convidando os CEAs para participar, buscando clarear seus objetivos e possibilidades para seus participantes e para aqueles que se passavam a olhar para este espaço como sendo um meio importante (dentre outros) para alavancar alguns de suas ações e projetos.

Cabe ressaltar que foram realizados outros eventos relativos à temática, com destaque para os I e II Encontro de CEAs do Estado do Rio de Janeiro, organizados respectivamente em 2003 e 2004, nas cidades de São Gonçalo e na capital, que buscaram identificar o "estado da arte" naquele estado, trocando experiências e reflexões entre iniciativas e buscando apontar para a consolidação de um "elo" local da Rede CEAs.

Entretanto, foram o EPCEAs e o ENCEA que contribuíram para o levantamento e a qualificação de subsídios para este estudo, na medida em que: 
- Possibilitaram encontros e trocas de experiências e de idéias entre educadores atuantes em CEAs, alguns já envolvidos no movimento da Rede CEAs e outros não;

- Permitiram observar as compreensões de educadores ambientais pouco familiarizados com esta temática com relação a sua concepção e indagações principais;

- Reforçaram a demanda crescente de informações sistematizadas e de espaços de interlocução qualificados sobre a temática, em contraposição à ausência de informações básicas quanto ao número de CEAs em atividade no Brasil; distribuição por regiões, dentre muitas outras;

- Evidenciaram a considerável diversidade de "tipos", concepções e até mesmo de denominações de CEAs em atividade no Brasil;

\section{B - Encontros virtuais}

Com o retorno dos questionários, por volta do início de 2003, a possibilidade e a facilidade de estabelecimento de contatos com CEAs de diferentes regiões, biomas e realidades foi criando condições extremamente favoráveis para a construção de uma rede de contatos e de inter-comunicação entre os CEAs. De fato, durante o início de 2003 este processo foi deflagrado com especial destaque para o estímulo à viabilização de uma lista de discussão para a Rede CEAs ${ }^{52}$. Também, neste período, a aprovação de projeto encaminhado ao Fundo de Cultura e Extensão da USP viabilizou diversas ações que contribuíram para assegurar a facilitação da Rede CEAs no período de maio de 2003 à maio de 2004:

- Elaboração, construção e manutenção de página eletrônica para a Rede CEAs, http://www.redeceas.esalq.usp.br, contendo informações conceituais sobre CEAs, textos, cadastros e listagens de CEAs brasileiros, contatos, links nacionais e internacionais;

\footnotetext{
52 Criada em março de 2003, a lista conta atualmente com a participação de mais de 300 pessoas, educadores ambientais que atuam em CEAs e em outras organizações, redes e instituições do campo da educação ambiental. Funciona através de um grupo virtual cujo provedor é do Departamento de Ciências Florestais da ESALQ (redeceas-I@jatoba.esalq.usp.br). Para solicitar inclusão ao grupo escrever para: redeceas@esalq.usp.br.
} 
- Facilitação da Rede propriamente dita: contatos, articulação, animação do grupo de e-mails, participação em eventos de EA e de CEAs; apoio e organização de eventos de EA e de CEAs; participação em reuniões com redes de EA e outras organizações da área.

No que diz respeito às ações de mediação e animação do grupo de e-mails da rede fazem-se necessárias algumas considerações. A partir da circulação de informações, contatos, materiais, etc, pelo grupo, e a partir das suas adesões, possibilitou-se a constituição de diversas pequenas parcerias informais. Sem dúvida a internet tem viabilizado inúmeros contatos, articulações, trocas de idéias, informações, contatos, etc, entre educadores ambientais, atuantes ou não em CEAs. A própria Rede Brasileira de Educação Ambiental (REBEA), surgida com os movimentos e articulações do Fórum Brasileiro de ONGs e Movimentos Sociais (chamado de "conferência paralela" da ECO-92), retomou considerável impulso não só com o advento da internet mas, sobretudo, com a sua expansão e maior utilização.

Os diversos contatos possibilitados por meio da internet, das suas diversas listas de discussão e, em especial, pelo grupo da Rede CEAs contribuíram para o desenvolvimento deste estudo de diversas maneiras: através da discussão sobre conceitos, em especial, acerca da temática dos CEAs; do acompanhamento de surgimento de novas iniciativas, de constituição de uma espécie de "diagnóstico empírico" continuado dos CEAs pertencentes e participantes daquele grupo virtual; e, inclusive, da construção do Encontro Nacional de CEAs realizado em Timóteo - MG, em outubro de 2003.

\subsubsection{Tabulação e análise dos dados}

O processo de tabulação foi manual, com a utilização do excel como ferramenta de sistematização geral dos dois questionários. De ambos delimitamos questões chaves que foram devidamente tabuladas, interpretadas e discutidas. Elas foram organizadas esquematicamente em oito grandes blocos, os quais serão as referências no capítulo sobre os Resultados desta pesquisa. Optou-se pela apresentação e discussão dos dados já agrupados nestes oito blocos ao invés de seguirmos fielmente a estrutura original dos questionários 1 e 2. 
Questões importantes no processo de tabulação e sistematização:

a) Respostas em branco, incompletas, ilegíveis e inteligíveis. Havendo qualquer dúvida na interpretação e entendimento de determinada informação nos questionários o procedimento adotado foi o de considerá-las como sendo "em branco", para não comprometer o conjunto dos dados;

b) Em algumas perguntas havia instruções do tipo "marque apenas 2 respostas", "marque no máximo três", dentre outras, contudo, aceitou-se todas as respostas que não seguiam o que a instrução indicava. Por exemplo, em questões de "marque no máximo três" com mais de três sinalizações, computavam-se todas elas, tantas quantas tivessem sido marcadas. Ressalva única para situações em que todas as alternativas estavam marcadas, quando então todas eram canceladas, ou seja, não computadas.

c) Consideradas estas premissas metodológicas, todas as demais informações contidas nos questionários foram consideradas e sistematizadas buscando-se resguardar seus elementos originais. Uma preocupação esteve presente desde o princípio, a de ser o mais fiel possível em todo o processo de sistematização das informações, de modo que os dados gerados pudessem, de fato, ilustrar um panorama o mais próximo possível da realidade concreta.

\subsubsection{Processo de tipologização}

A construção de categorias para os CEAs brasileiros foi, fundamentalmente, estruturada a partir da revisão da literatura espanhola que será apresentada no capítulo seguinte - "Classificação Tipológica de CEAs". Ela permitiu a visualização de indicadores que nortearam a "leitura" dos questionários. Mas, não foi somente esta revisão que viabilizou este processo, entretanto, constituiu-se na sua base teóricoconceitual.

$\mathrm{Na}$ verdade, foram construídos dois procedimentos distintos para a construção de categorias de CEAs brasileiros, sendo uma via simples e uma via complexa. A primeira constituiu-se na simples adoção de um único indicador e uma conseqüente proposta de classificação tipológica realizada junto à amostra disponível. Neste caso, o indicador adotado foi o de "Tipo de Instituição Promotora" do CEA, chegando-se numa proposta tipológica com nove classes, quais sejam: Empresas, públicas, empresas 
privadas, universidades, fundações, governo federal, governos estaduais, ONGs, prefeituras e outros.

No processo complexo de construção de classificação tipológica, adotamos como base a revisão de literatura espanhola, da qual foi possível a "extração" de indicadores mais freqüentes, complementada pelo conhecimento prático de alguns CEAs brasileiros, como veremos na Figura 2:

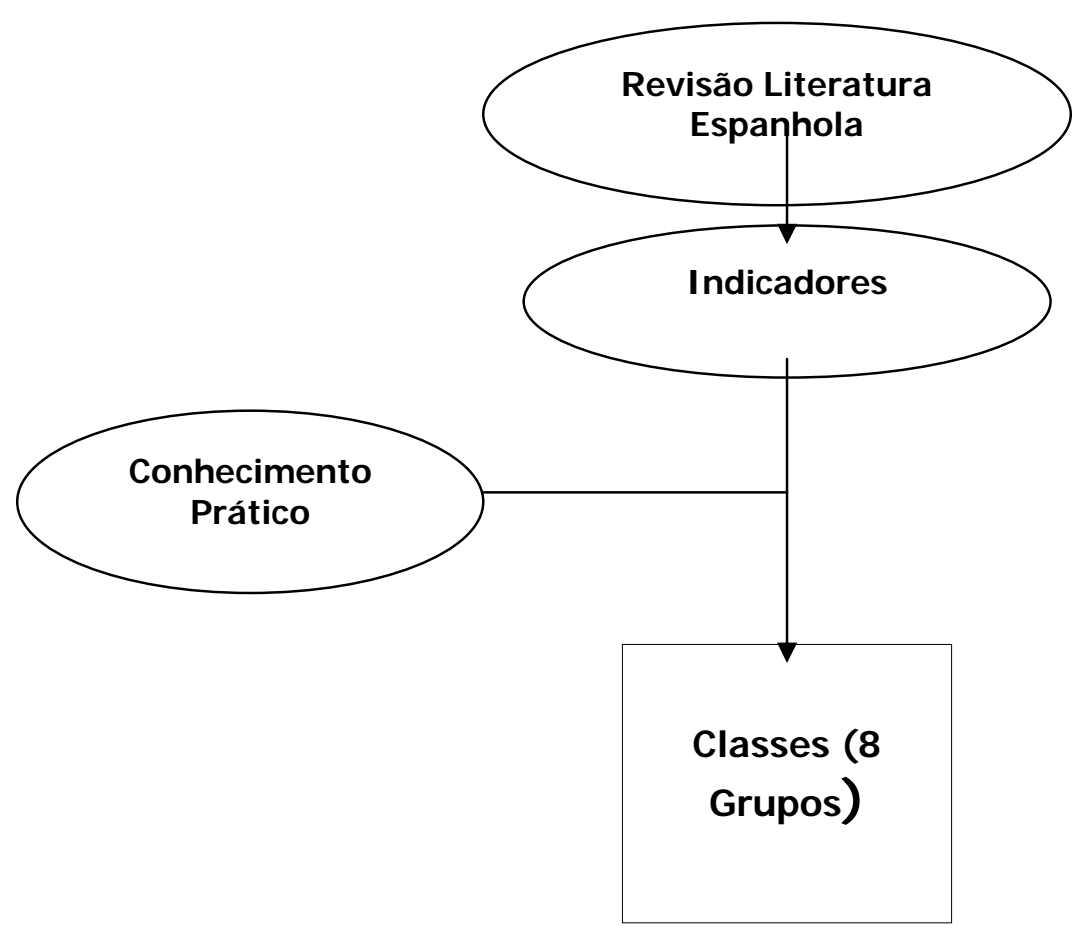

Figura 4 - Esquema do processo complexo de tipologização 


\section{RESULTADOS E DISCUSSÃO}

\subsection{Proposta de classificação tipológica de CEAs Brasileiros}

Neste capítulo, propomos uma tipologia-base para os CEAs brasileiros, acompanhada por uma outra possibilidade de classificação tipológica de CEAs. Esta proposta de tipologia-base foi concebida a partir da adoção de uma série de critérios empíricos como fios condutores nesse processo. Há, segundo Pérez $(2001)^{53}$, ao menos dois caminhos distintos para construir-se propostas desta natureza: o primeiro, mais prático e empírico, consiste em visitar uma série de iniciativas (ao tempo que recordamos aquelas anteriormente visitadas) a fim de propor classificações baseadas na experiência acumulada sobre o assunto; e o segundo consiste na adoção de critérios para nortear a construção de categorias tipológicas, ou seja, possui um caráter mais teórico.

Inicialmente nos propusemos a percorrer os dois caminhos indicados pelo autor, construindo uma proposta tipológica com base em critérios selecionados para, num segundo momento, verificar in loco uma amostra das iniciativas a fim avaliar e incrementar a proposta. O que tornou-se inviável em virtude de dificuldades financeiras para viabilizar o deslocamento aos CEAs além, é claro, do tamanho e da distribuição da amostra (101 iniciativas em todas as regiões do Brasil).

Adotamos como estratégia metodológica para a etapa de tipologização a proposta de identificação do maior número possível de critérios que facilitassem a construção de classificações de CEAs brasileiros, mas que também permitissem fazêla com uma margem maior de confiança. Assim, construímos uma proposta de tipologia-base para CEAs brasileiros, a qual será descrita a seguir. Propusemos, ainda,

\footnotetext{
${ }^{53}$ Entrevista concedida ao pesquisador.
} 
uma outra classificação tipológica, adotando como base um único critério empírico "Instituição Promotora de CEAs".

\section{A - Segundo um conjunto de critérios}

A partir da análise de alguns critérios no conjunto da amostra foram construídas oito classes de CEAs, como vemos a seguir:

- Localização do CEA;

- Espaços, equipamentos e recursos disponíveis;

- Instituição promotora e caráter da gestão do CEA;

- Características do entorno;

- Público atendido;

- Tipo, Freqüência e Duração das Atividades realizadas;

- Objetivos/Missão do CEA;

- Projeto Político Pedagógico.

Estes critérios foram definidos a partir da construção e análise da Tabela 2 (Revisão da Literatura), relativo a tipologias de CEAs encontradas na Espanha, que forneceu diversos critérios adotados para a proposição das categorias tipológicas. A partir da análise dos questionários ( 1 e 2) de todo o conjunto amostral, chegamos a uma proposta de Classificação Tipológica para CEAs Brasileiros subsidiada em oito grandes grupos/tipos de iniciativas, conforme a Tabela 10:

Tabela 10. Classificação Tipológica de CEAs Brasileiros

\begin{tabular}{|c|c|c|}
\hline $\mathrm{N}^{0}$ & $\begin{array}{c}\text { Funções Principais do } \\
\text { Grupo }\end{array}$ & Características principais do Grupo \\
\hline G1 & $\begin{array}{l}\text { Disponibilizar } \\
\text { Informações }\end{array}$ & $\begin{array}{l}\text { A maioria dos CEAs vinculados ao setor privado pautam } \\
\text { suas atividades em produção e/ou disseminação de } \\
\text { informações ambientais. Não oferecem cursos e } \\
\text { oficinas. }\end{array}$ \\
\hline
\end{tabular}


Tabela 10. Classificação Tipológica de CEAs Brasileiros

\begin{tabular}{|c|c|c|}
\hline $\mathrm{N}^{\circ}$ & $\begin{array}{c}\text { Funções Principais do } \\
\text { Grupo }\end{array}$ & Características principais do Grupo \\
\hline G2 & $\begin{array}{l}\text { Sensibilização, } \\
\text { Reflexão e Revisão de } \\
\text { Valores }\end{array}$ & $\begin{array}{l}\text { A grande maioria funciona aos finais de semana. São } \\
\text { iniciativas semelhantes às do G4, porém suas principais } \\
\text { atividades não restringem-se às trilhas. A maioria } \\
\text { desenvolve atividades de produção de materiais, } \\
\text { palestras, oficinas e visitas orientadas. Localizam-se, } \\
\text { fundamentalmente, em áreas urbanas. Pode ser } \\
\text { considerado didaticamente como sendo uma fusão } \\
\text { entre G1 e G4. }\end{array}$ \\
\hline G3 & $\begin{array}{l}\text { Atividades } \\
\text { Formação }\end{array}$ & $\begin{array}{l}\text { CEAs localizados tanto em áreas urbanas quanto rurais. } \\
\text { Metade deles oferece atividades de longa duração. } \\
\text { Produzem e/ou disseminam informações e } \\
\text { desenvolvem ações de vocação formativa, como cursos } \\
\text { e oficinas. Em média, verifica-se } 2 \text { (duas) instituições } \\
\text { promotoras dos CEAs deste grupo com boa } \\
\text { participação de ONGs. A maioria dos CEAs apresenta } \\
\text { aporte financeiro de procedência mista (setor público e } \\
\text { privado). }\end{array}$ \\
\hline G4 & $\begin{array}{l}\text { Atividades } \\
\text { Interpretação }\end{array}$ & $\begin{array}{l}\text { Oferece, majoritariamente, atividades de curta duração, } \\
\text { como as trilhas interpretativas voltadas ao público } \\
\text { escolar. Metade destes CEAs estão localizados em } \\
\text { Unidades de Conservação - são os chamados "Centros } \\
\text { de Visitantes". Um quarto não dispõe de computadores } \\
\text { e não produz qualquer tipo de material, sendo a maioria } \\
\text { vinculado ao setor público. Prefeituras e Empresas } \\
\text { Privadas correspondem a } 60 \% \text { das instituições } \\
\text { promotoras de CEAs. Grande maioria funciona aos } \\
\text { finais de semana. }\end{array}$ \\
\hline
\end{tabular}


Tabela 10. Classificação Tipológica de CEAs Brasileiros

\begin{tabular}{|c|c|c|}
\hline $\mathrm{N}^{\circ}$ & $\begin{array}{c}\text { Funções Principais do } \\
\text { Grupo }\end{array}$ & Características principais do Grupo \\
\hline & $\begin{array}{l}\text { Delinear e implementar } \\
\text { projetos, consultorias, } \\
\text { eventos }\end{array}$ & $\begin{array}{l}\text { Maioria dos CEAs vinculados ao setor público. Pouco } \\
\text { mais da metade das iniciativas surgem no início dos } \\
\text { anos 90, como: NEAs do IBAMA, núcleos de } \\
\text { universidades e de ONGs. Em média, verifica-se } 2 \\
\text { (duas) instituições promotoras dos CEAs deste grupo. } \\
\text { Metade dos CEAs deste grupo oferece atividades de } \\
\text { longa duração, constituindo-se em um dos grupos onde } \\
\text { os CEAs mais dispõem de Projetos Políticos } \\
\text { Pedagógicos. }\end{array}$ \\
\hline G6 & $\begin{array}{l}\text { Articular para } \\
\text { potencializar ações }\end{array}$ & $\begin{array}{l}\text { Maioria dos CEAs vinculados ao setor privado. As } \\
\text { ONGs constituem-se em metade das Instituições } \\
\text { promotoras de CEAs deste grupo. É um dos grupos } \\
\text { onde os CEAs mais dispõem de Projetos Políticos } \\
\text { Pedagógicos. }\end{array}$ \\
\hline G7 & $\begin{array}{l}\text { Lazer, ócio, lúdico- } \\
\text { cultural }\end{array}$ & $\begin{array}{l}\text { Verifica-se a parceria de pelo menos } 2 \text { (duas) } \\
\text { instituições promotoras dos CEAs. São CEAs que } \\
\text { surgiram mais recentemente (meados dos anos 90), } \\
\text { principalmente em áreas urbanas. Apresentam certa } \\
\text { vinculação com Parques Urbanos e áreas verdes. }\end{array}$ \\
\hline G8 & $\begin{array}{l}\text { Desenvolver } \\
\text { de pesquisa }\end{array}$ & $\begin{array}{l}\text { Maioria dos CEAs vinculados ao setor público } \\
\text { (universidades, fundações, centros de pesquisa, } \\
\text { prefeitura) Verifica-se } 2 \text { (duas) instituições promotoras } \\
\text { em cada CEA deste grupo (leiam-se parcerias). }\end{array}$ \\
\hline
\end{tabular}

Segundo a Figura 5 (abaixo), os grupos que mais cresceram no período de 1993-2003 foram os de número 2, 4 e 6, com os respectivos percentuais: $88 \%, 75 \%$ e $50 \%$. Os grupos 2 e 4 representam propostas de CEAs de vocação conservacionista e aquelas iniciativas que trabalham com atividades de sensibilização, reflexão e 
estimulam a revisão de valores. O G6 atua numa perspectiva de articulação para potencializar ações das pessoas com as quais relaciona-se.

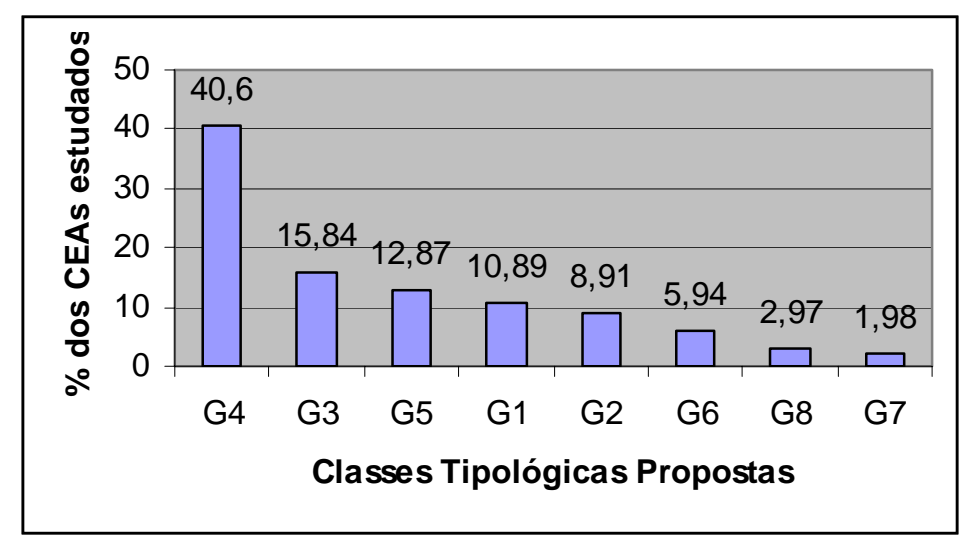

Figura 5 - Distribuição dos CEAs nas Classes propostas

Os grupos, com exceção do G3 e do G4, estão majoritariamente localizados em áreas urbanas. O primeiro constitui-se numa classe que se encontra situada tanto em aéreas urbanas quanto rurais, mas com leve predomínio desta última e desenvolve ações de formação utilizando-se dos elementos do entorno como cenários pedagógicos. O grupo seguinte (G4), encontra-se localizado em áreas rurais e em unidades de conservação e desenvolvem atividades de vocação conservacionista, como trilhas de interpretação da natureza, vivências, dinâmicas, palestras, exposições, dentre outras. Trata-se do grupo mais freqüente no levantamento realizado, representando $40 \%$ da amostra. É, ainda, o grupo mais "antigo" dentre os CEAs do país, uma vez que engloba aqueles considerados "pioneiros" e que possuem o perfil de "Centro de Visitantes" de Unidades de Conservação. Após estes "pioneiros" começaram a emergir iniciativas mais vinculadas ao $\mathrm{G} 3$, como pequenas propriedades rurais, vinculadas prioritariamente: ao desenvolvimento de atividades educacionais voltadas à questão ambiental, à busca por sistemas alternativos de produção e consumo, ao desenvolvimento de ações de recuperação de áreas degradadas, dentre outros vínculos e enfoques. 
A classe denominada como G5, caracterizada pelo delineamento e pela implementação de projetos, consultorias e eventos, foi a terceira com o maior percentual de freqüência (aproximadamente 13\%) em relação à amostra de CEAs. Estão incluídas nessa classe a maior parte dos NEAs do IBAMA, os laboratórios de EA de diversas universidades brasileiras e algumas empresas privadas, dentre outros tipos de iniciativas.

Quanto ao grupo G1, que representa cerca de 11\% da amostra, refere-se aos CEAs com foco mais direcionado para a disponibilização de informações. Trata-se de iniciativas preferencialmente urbanas que não desenvolvem cursos nem oficinas, atuando na promoção palestras, distribuição de materiais, visitas orientadas, dentre outras atividades centradas na transmissão de informações.

O grupo G2 é composto por iniciativas semelhantes às da classe anterior (G1) e ao G4, tratando-se de CEAs que, além de disponibilizar informações, atuam no sentido de promover processos de sensibilização, reflexão e revisão de valores. Em geral isso é proporcionado por meio de atividades que utilizam o entorno como cenário pedagógico, assim como oficinas, vivências, dinâmicas, exposições, que vão além da disponibilização de informações.

Quanto a classe G6, encontrada em aproximadamente $6 \%$ da amostra, visualiza-se os CEAs mais ligados à ONGs e que pautam sua missão na articulação para potencializar ações. Têm um foco de atuação comunitário, social e político, sendo que em geral sabem muito bem para "onde querem caminhar". Nesta categoria estão os CEAs mais sintonizados com os dois princípios orientadores deste trabalho participação e diálogo - porque promovem processos que facilitam, estimulam e orientam seus públicos para participar de processos educacionais cujo elemento chave é o diálogo. É uma classe onde estão os CEAs que, via de regra, possuem um relacionamento marcadamente comunitário, de envolvimento social com os segmentos com os quais atua e onde se localiza.

O grupo G7 representa os CEAs vinculados a ações de lazer, ócio e lúdicocultural com iniciativas marcadamente ligadas à parques e áreas verdes urbanas, significando quase $2 \%$ da amostra. Constituem-se em alternativas de lazer e descanso, envolvendo processos educacionais de vocação lúdica que trabalham elementos da cultura humana, como manifestações artísticas, dentre outras. 
Por fim, temos a categoria G8 representando aproximadamente 3\% dos CEAs estudados que desenvolvem iniciativas voltadas à pesquisa. Estes são vinculados a instituições públicas - sobretudo universidades e centros de pesquisa, e tem como foco principal o desenvolvimento de projetos de pesquisa em EA. CEAs com essas características são pouco comuns no país, configurando-se em iniciativas consideravelmente importantes para a EA brasileira.

\section{B - Segundo a adoção de um único critério}

A outra proposta tipológica está alicerçada em um único critério que é a instituição promotora e gestora de CEAs no Brasil na atualidade. Trata-se de uma tipologização simples, baseada em um único critério para a proposição das categorias de CEAs com uma intencionalidade marcadamente pedagógica. Nessa proposta é possível identificar nove classes de CEAs, sendo iniciativas vinculadas a:

1) Empresas Públicas;

2) Órgãos Governamentais Federais;

3) Órgãos Governamentais Estaduais;

4) Órgãos Governamentais Municipais (prefeituras);

5) Fundações;

6) Universidades;

7) Empresas Privadas;

8) ONGs;

9) Outras instituições (agências de cooperação, consórcios, etc).

Embora possamos visualizar convergências entre os CEAs das classes propostas, faz-se necessário estudos mais aprofundados sobre o tema que possibilitem o levantamento de outros elementos que permitam discutir a questão com subsídios mais concretos. Ressaltamos que se trata de um primeiro esforço de construção de classificações tipológicas de CEAs brasileiros e que as propostas aqui apresentadas devem ser encaradas como um processo em permanente construção e continuada reflexão e avaliação. Acreditamos, contudo, que à medida que este estudo contribua para suscitar reflexões entre pessoas que atuam e se relacionam com o campo da EA o mesmo favorecerá o surgimento de novas idéias e, conseqüentemente, 
de propostas que complementem, questionem ou refutem o que, parcialmente ou totalmente, o que constituiu o propósito deste trabalho.

Compartilhamos da idéia de que, de fato, o caminho se faz ao caminhar, e de que a conquista ocorre na medida em que o caminhante depara-se com os desafios, os quais abrem perspectivas de possibilidades e alternativas, desde que este caminhante queira percebê-las para, a partir de então, potencializar-se para agir. E, para além da ação, a necessidade de reflexão, de avaliação, de dialogar sobre o que foi praticado e de enxergar outros caminhos, outros desafios, novas possibilidades e novas ações.

\subsection{Uma panorâmica dos CEAs no Brasil}

As informações e os dados levantados permitem-nos organizar um retrato dos CEAs no país. Optamos por uma estruturação baseada nos dois principais instrumentos de coleta (questionários 1 e 2) e, ao invés de seguir fielmente as "partes" dos questionários, organizamos esta "panorâmica" da seguinte maneira:

- Bloco 1 - Compreendendo as Informações de caráter geral do CEA, como: localização, instituições promotora e gestora, período de funcionamento, dentre outras;

- Bloco 2 - Informações sobre Edificações, Infra-estrutura e recursos disponíveis no CEA, como: características da edificação-sede, dos espaços e do entorno, relação dos recursos e equipamentos presentes no CEA, produção de materiais, e outras;

- Bloco 3 - Dados do Público Atendido, abordando: quem são, quantos são, de onde vêm, como conheceram o CEA, dentre outras;

- Bloco 4 - Equipe Pedagógica: quantos membros, formação, média salarial, etc;

- Bloco 5 - Atividades Desenvolvidas, abordando: a relação das intervenções mais freqüentes, a duração delas e os temas trabalhados;

- Bloco 6 - Sobre o Projeto Político-Pedagógico, relacionando se o CEA dispõe de um Projeto ou não, motivos para não possuí-lo, formas de avaliação empregadas e como concebem o tema da Biodiversidade; 
- Bloco 7 - Situação Atual e Perspectivas, buscando englobar os principais problemas enfrentados na atualidade pelos CEAs e as perspectivas para os próximos cinco anos; e

- Bloco 8 - Denominando de Espaço Livre, neste bloco o CEA poderia tecer comentários de qualquer natureza, seja crítica, informativa, além de poder avaliar os questionários.

Apresentados os oito blocos estruturantes do que denominamos como "Panorâmica dos CEAs no Brasil", iniciaremos a explanação dos dados levantados, seguidos pela discussão.

A) Bloco 1 - informações de caráter geral do CEA

O primeiro dado levantado neste item refere-se à localização do CEA em termos de distribuição geográfica no país. Foram construídos dois gráficos (Figuras 6 e 7) que ilustram essa distribuição, sendo um que considera as cinco regiões brasileiras e o outro as Unidades Federativas.

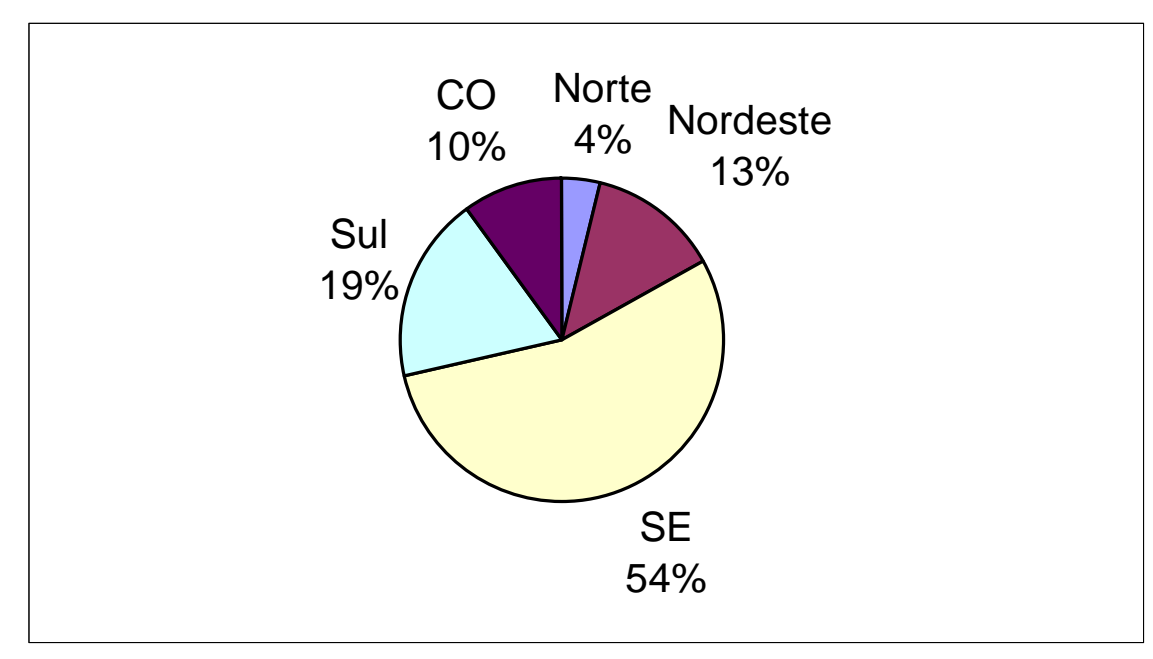

Figura 6 - Distribuição dos CEAs por Região

Como vemos na Figura 6, há uma considerável desigualdade na distribuição dos CEAs entre as distintas regiões brasileiras. Enquanto o Sudeste concentra mais da metade (54\%) dos CEAs estudados, a região Norte ficou na faixa dos $4 \%$. Os dados 
contidos neste gráfico podem indicar um padrão de distribuição dos CEAs no país, embora seja preciso observar-se algumas questões quanto ao envio dos kits para as Regiões/Estados. A observação e a análise comparativa da Tabela 6, relativo à distribuição dos kits remetidos por região (ver capítulo "Metodologia") com Figura 6 indicam que há considerável semelhança entre os percentuais. Há apenas uma pequena reordenação dos dados na Figura 6 , em que se verifica a ocorrência de um acentuado aumento no percentual de retorno relativo às regiões Sudeste e Sul em detrimento das demais regiões que tiveram alguma redução, em especial à região Norte que teve seu percentual reduzido à metade (caiu de 8,4\% para 4\%).

Há um trabalho de Quintão (1983) que aborda a evolução do conceito de Parques Nacionais e sua relação com o processo de desenvolvimento no Brasil, em que o mesmo afirma que, "em geral, a criação de Parques Nacionais ou outras áreas protegidas, precede ou coincide o avanço de frentes pioneiras sobre regiões virgens. Desta forma, o desenvolvimento estaria impulsionando a criação de áreas naturais protegidas" (Quintão, 1983, p.13).

Com relação à existência de um provável padrão de distribuição de CEAs no país podemos inferir que há certa convergência com o que afirma a autora. Se considerarmos que as Regiões Sudeste e Sul são aquelas que apresentam um padrão dito "mais desenvolvido" do que as demais, a observação e a análise dos dados levantados permitem-nos concordar com a autora e inferir que há um padrão de distribuição que acompanha o eixo desenvolvimentista brasileiro. As duas regiões (Sudeste e Sul) concentraram $73 \%$ dos CEAs estudados, sendo que só a Região Sudeste concentrou 54\%, enquanto que a Região Norte possui apenas $4 \%$. 


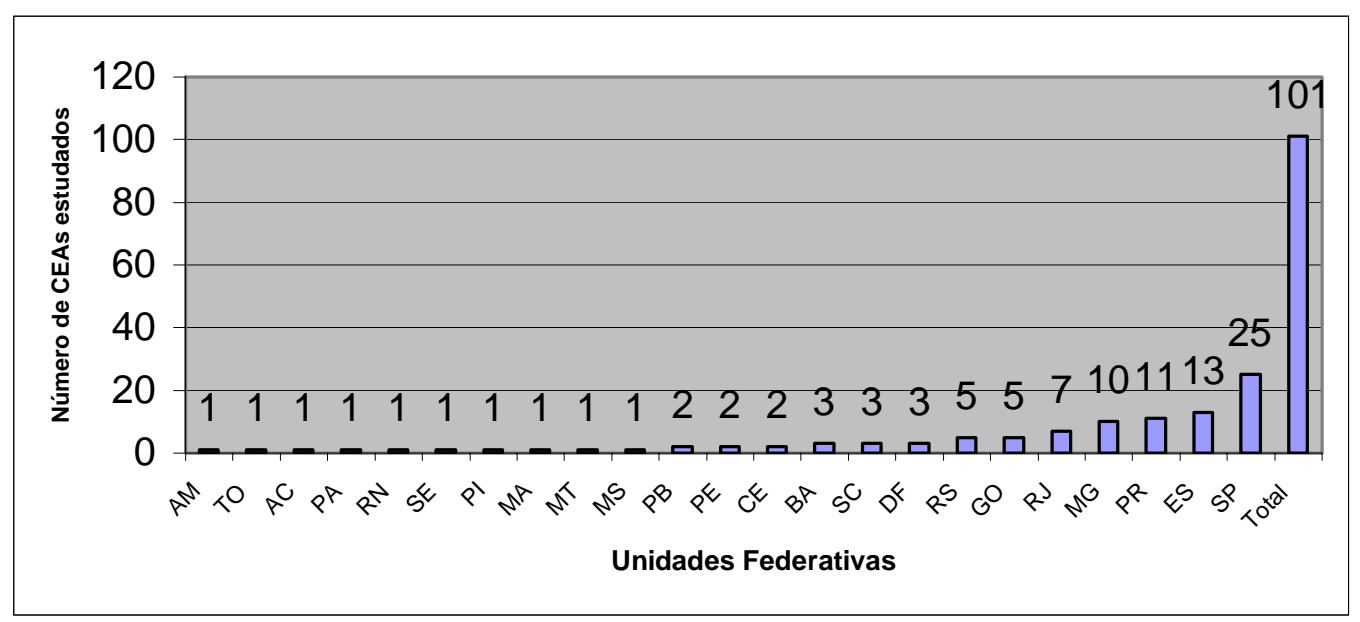

Figura 7 - Distribuição dos CEAs por Unidades Federativas

A partir da observação da Figura 7 podemos constatar que há considerável desigualdade na distribuição entre as Unidades Federativas de distintas regiões e, inclusive, na mesma região. Os Estados que mais apresentaram CEAs foram os de São Paulo (com 25), Espírito Santo (com 13), Paraná (11) e Minas Gerais (10) que, juntos, alcançam a marca de aproximadamente $70 \%$ da amostra estudada. Por outro lado, diversos Estados tiveram apenas um CEA considerado neste estudo (Amazonas, Tocantins, Acre, Pará, Rio Grande do Norte, Sergipe, Piauí, Maranhão, Mato Grosso e Mato Grosso do Sul), quatro não tiveram nenhuma iniciativa presente na amostragem deste trabalho, sendo três da Região Norte (Amapá, Rondônia e Roraima) e um da Região Nordeste (Alagoas).

A Tabela 5 (ver "Metodologia") indica como foram remetidos os kits para as Unidades Federativas e que todas foram contempladas, de acordo com a disponibilidade de informações sobre iniciativas de CEAs.

A Figura 8 ilustra o momento do surgimento dos CEAs e adota como referência as quatro Fases propostas por este trabalho no item "Histórico dos CEAs no Brasil" (Fundacional - 1976 - 1987; da "Oficialização" - 1988 - 1992; da "Efetivação" - 1993 1997; e Atual - 1998 - 2003). 


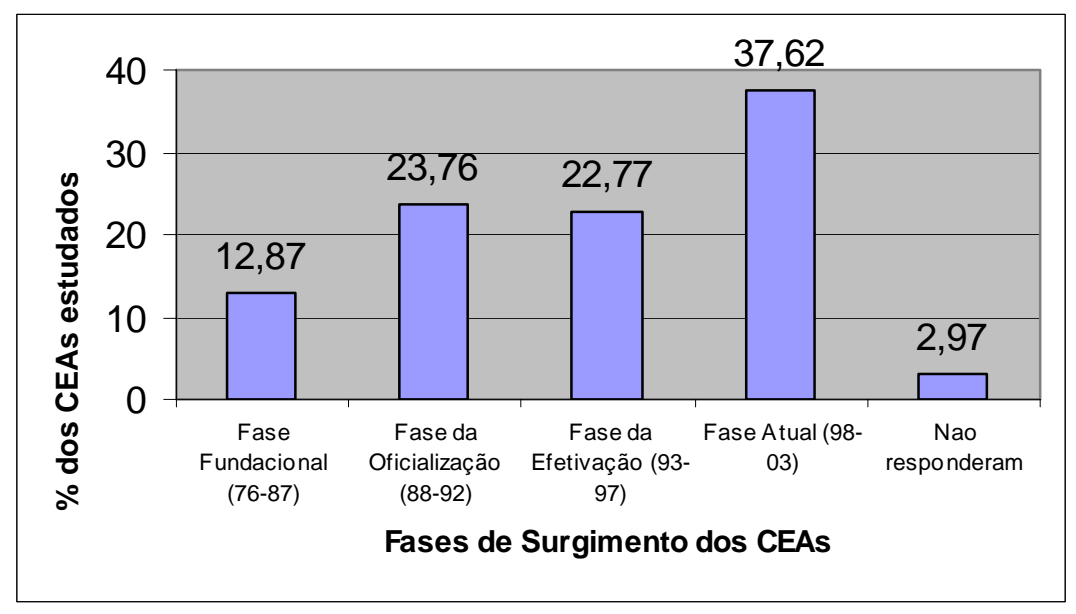

Figura 8 - Fases de Surgimento dos CEAs

A Figura 8 ilustra a distribuição dos CEAs dentro das quatro fases propostas por este estudo. Os dados indicam que há uma considerável concentração de iniciativas que iniciam sua trajetória após 1992, representando 60\% do total de CEAs estudados. Verificamos que no período pós 1998, o qual representa a Fase Atual, concentra-se o "nascimento" da maioria das iniciativas (quase 38\%). Esta observação permite-nos afirmar que a década de 90 , de fato, representa um período de notável "explosão" de CEAs no país.

É possível observar também que há a indicação de uma tendência de crescimento, a qual concede mais argumentos para a necessidade de trabalhos de mapeamento, levantamento de CEAs, sistematização e disponibilização de informações sobre a temática.

Por outro lado, verificamos que um percentual considerável (quase 13\%) de CEAs surgem no período 1976-1987, o qual denominamos como sendo a "Fase Fundacional", seguida de aproximadamente $24 \%$ relativos à "Fase da Oficialização", que vai de 1988-1992. Esta fase engloba a ECO-92 que, como vimos, exerceu importante influência sobre a oferta de iniciativas de CEAs no país. A Figura indica, ainda, um pequeno percentual (cerca de $3 \%$ ) que não respondeu à questão. 


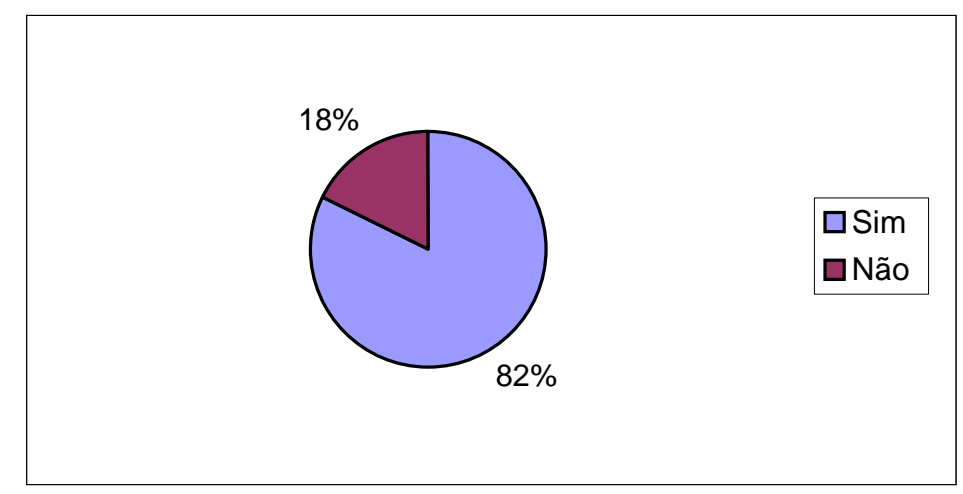

Figura 9 - Disponibilidade de Correio Eletrônico nos CEAs

A Figura 9 demonstra que, no conjunto dos 101 CEAs estudados, a grande maioria (82\%) dispõe de um correio-eletrônico. Trata-se de um dado que surpreendeu quando da tabulação dos dados deste estudo e representa um potencial considerável de acesso e intercâmbio de informações entre os CEAs que vem sendo pouco explorado. A proposta de criação da Rede CEAs, inicialmente gestada como sendo um canal que viesse a facilitar a troca de informações entre CEAs, sobretudo via internet, foi ganhando força a partir do retorno dos questionários. Como podemos verificar no Gráfico 6, a grande maioria dos CEAs dispõe de correio-eletrônico, o que nos possibilita inferir que dispõem de algum meio de acesso à internet. Este pode ocorrer tanto nas dependências do CEA como nas residências de membros da sua equipe pedagógica.

No entanto, há um percentual de 18\% de CEAs que não dispõem de correioeletrônico, o que nos permite inferir que estas iniciativas ou não tem qualquer forma de acesso à internet ou o tem com dificuldade. É provável que este percentual diminua com o passar dos anos, sobretudo pela facilidade de conexão à internet (em especial através de provedores gratuitos) e pela redução de custos de provedores pagos (devido à concorrência). 


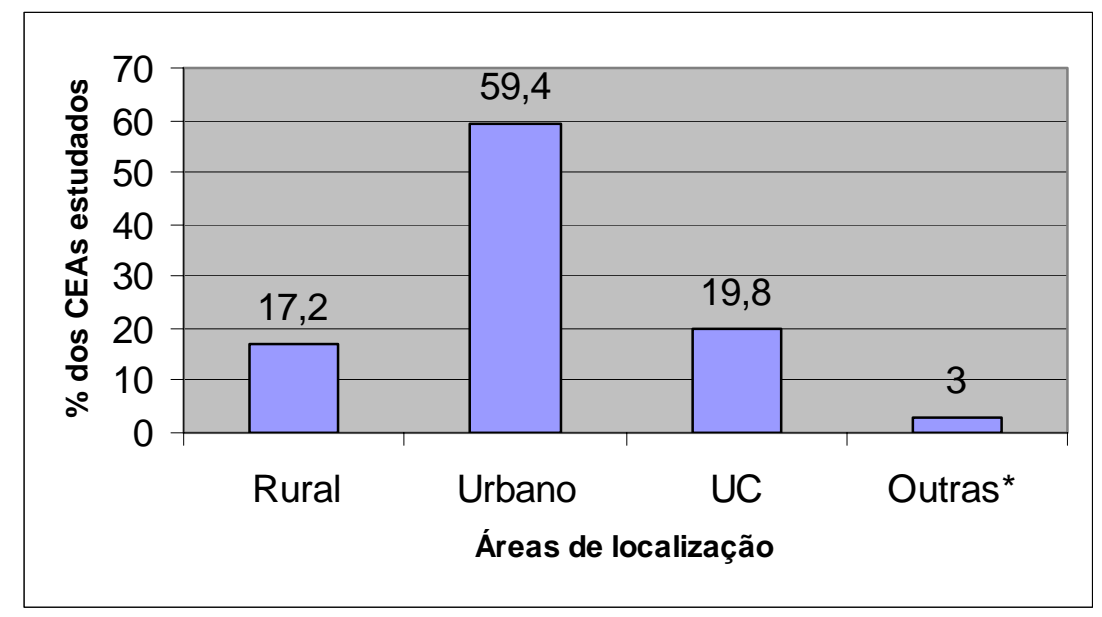

* Áreas industriais, estação de tratamento de esgoto, CEA móvel

Figura 10 - Localização dos CEAs

A observação da Figura 10 permite-nos verificar que quase $60 \%$ dos CEAs situam-se em áreas urbanas, dentre os quais há considerável diversidade de localizações. Há CEAs situados em parques urbanos, áreas verdes, em regiões centrais de cidades, como também há iniciativas localizadas em periferias de grandes e médios centros urbanos. Houve, também, certa surpresa ao observar este dado, pois ele contradiz o cenário espanhol de localização de CEAs. Enquanto na Espanha observa-se um percentual elevado de CEAs localizados tanto em áreas rurais quanto em espaços naturais protegidos e uma minoria de iniciativas situadas em áreas urbanas, aqui no Brasil o panorama verificado é o oposto.

No Brasil observa-se uma tendência mais próxima à da Espanha somente na Fase Fundacional de surgimento de CEAs, ou seja, aquela que vai de 1976 a 1987, quando a maior parte delas nasce em Unidades de Conservação e em pequenas propriedades rurais. Nas demais fases ocorre uma inversão nesta tendência e os CEAs localizados em áreas urbanas passam a predominar no conjunto dos CEAs brasileiros. Se refletirmos a partir da perspectiva de que a maioria da população brasileira vive em áreas urbanas verificamos que os CEAs, então, encontram-se localizados estrategicamente para atender a esta demanda.

A Figura 10 aponta-nos, ainda, para uma minoria de iniciativas (3\%) que ou não compreenderam a pergunta e optaram por responder que o CEA está localizado em áreas industriais ou junto a Estações de Tratamento de Esgoto ou refere-se a um CEA 
móvel, presente na amostra estudada. Iniciativas de caráter móvel são pouco freqüentes no Brasil e tem potencial interessante para expandirem-se. Um CEA móvel pode apresentar uma série de vantagens, como a facilidade de atingirem públicos bem distintos e localizados em regiões pouco servidas deste tipo de iniciativas, dentre outras.

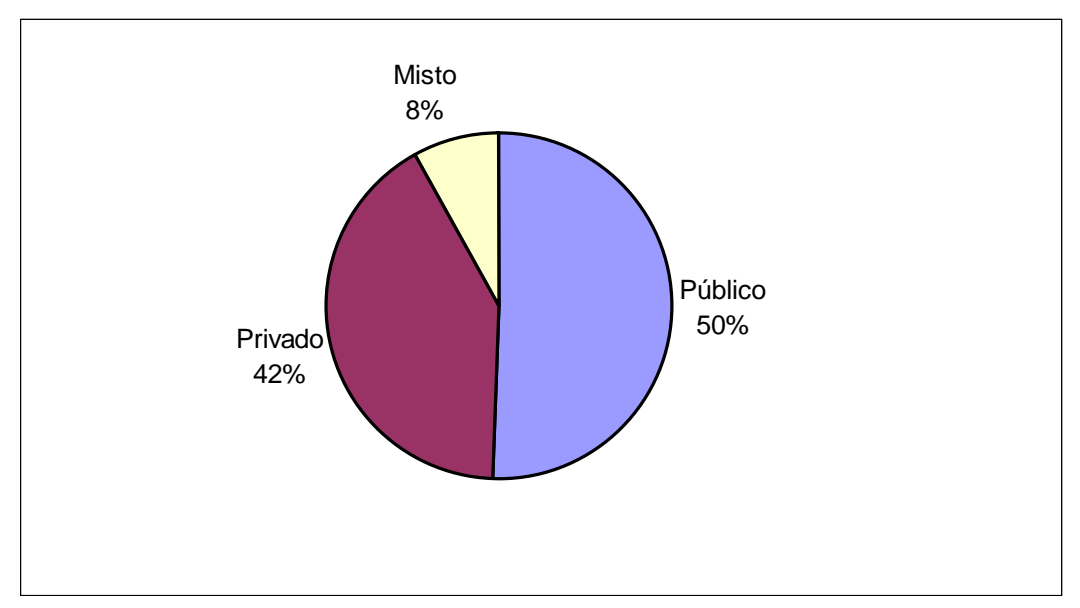

Figura 11 - Gestão dos CEAs

Observa-se, na Figura 11, que há uma leve predominância de CEAs geridos pelo setor público, representando a metade da amostra estudada, seguidos pelos CEAs de gestão de caráter privado (42\%) e pelas iniciativas mistas (8\%). De fato, o setor público é responsável pela promoção e pela gestão de diversos CEAs no país por meio dos seus diversos setores, instituições e órgãos, como: prefeituras, órgãos estaduais e federais de meio ambiente, fundações e universidades.

É preciso analisar esta figura em comparação com a figura seguinte, o qual aponta para a procedência da verba responsável pela manutenção/gestão do CEA. 


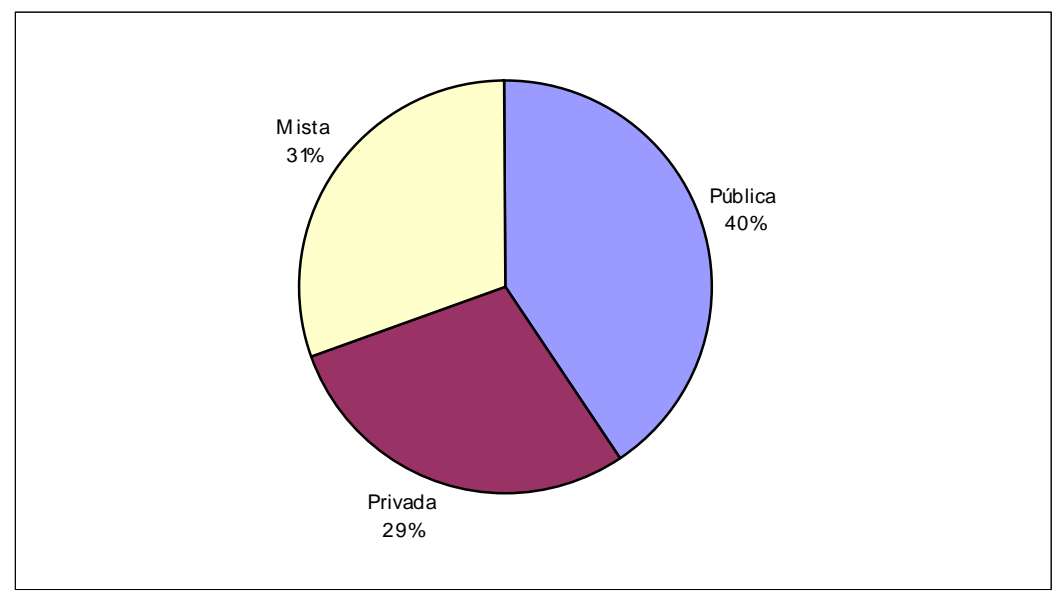

Figura 12 - Procedência da verba dos CEAs

A Figura 12, em comparação com a anterior, indica que há uma redução na participação do setor público na gestão dos CEAs quando considera-se na análise o fator "verba". Embora o setor público seja o responsável pela gestão de 50\% dos CEAs estudados (Figura 11) ele aporta recursos financeiros somente para $40 \%$ destes CEAs, enquanto que se nota um considerável crescimento de iniciativas de caráter misto que, no gráfico anterior é de somente $8 \%$, neste aumenta para $31 \%$. Isto demonstra que muitos CEAs, embora promovidos e geridos pelos setores público e privado, captam recursos para sua manutenção em fontes de diversos setores. Um exemplo típico observado é quando uma determinada instituição seja pública ou privada, promove um CEA sendo a responsável pela sua gestão, mas não aporta a totalidade dos recursos financeiros necessários para a completa manutenção do CEA. Busca-se, então, estabelecer parcerias que possibilitem a entrada de recursos para a manutenção do CEA. Trata-se de uma situação bastante comum na atualidade e que tende a crescer de duas formas. Uma, relativa ao percentual de CEAs que adotam essa estratégia e a outra refere-se àqueles CEAs que já o adotam buscando ampliar seu leque de parceiros não limitando-se somente a um único parceiro. 


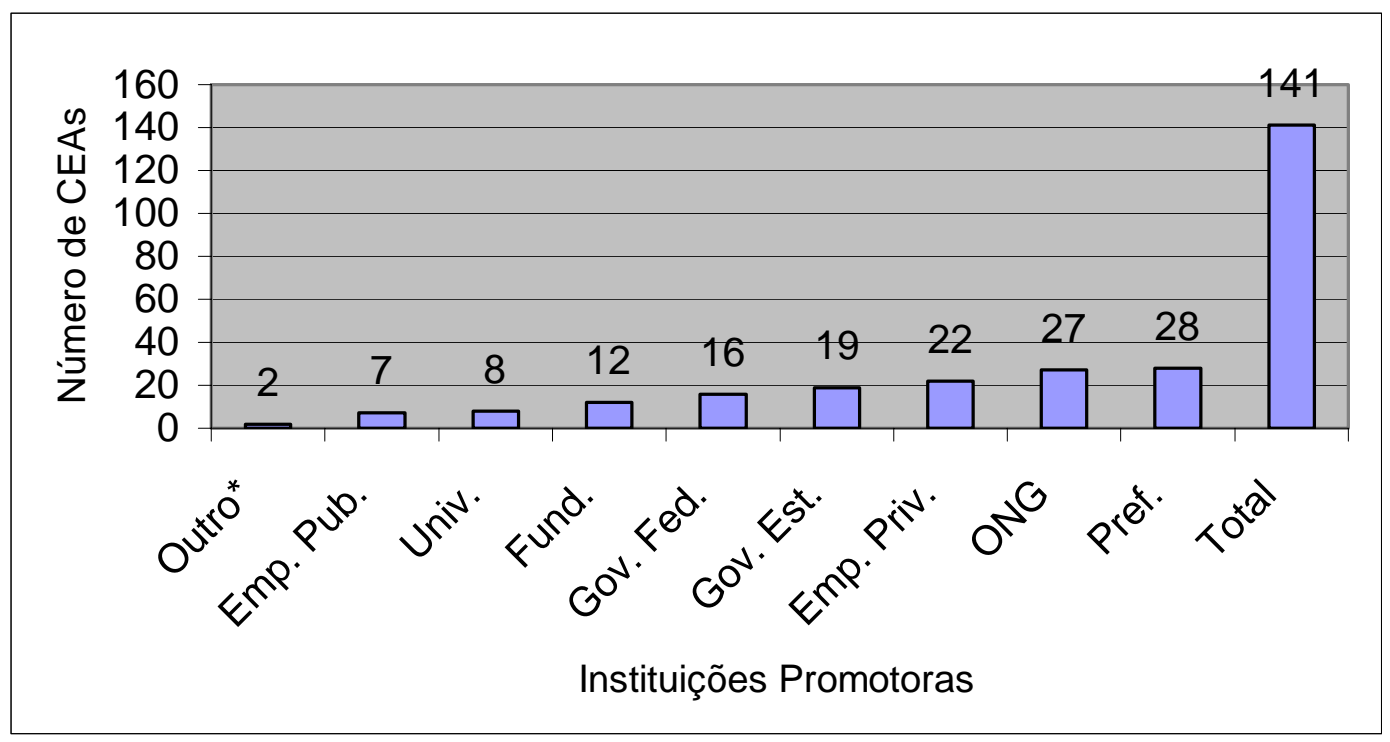

Figura 13 - Instituições promotoras dos CEAs

Observa-se, na Figura 13, que as prefeituras são as instituições que mais promovem CEAs no país, seguidas das ONGs e das Empresas Privadas. A grande maioria dos CEAs (77 CEAs) respondeu ter como instituição promotora alguma destas três instituições (ou mais de uma destas). Esta figura também possibilita a visualização da diversidade de instituições responsáveis pela promoção de CEAs no país, que vão desde prefeituras, ONGs, empresas privadas até empresas públicas, universidades e fundações além das esferas governamentais federal e estadual. A tabulação e análise dos dados permitiram-nos concluir que cerca de 30\% dos CEAs apresentam mais de uma instituição como promotora, o que explica o número de 141 na coluna "total" do Gráfico 10, ao invés de 101, que é o universo de CEAs considerados neste estudo.

B) Bloco 2 - Edificações, Infra-estrutura e recursos disponíveis no CEA

Neste bloco veremos dados relativos aos recursos materiais, estruturais e pedagógicos disponíveis nos CEAs . 


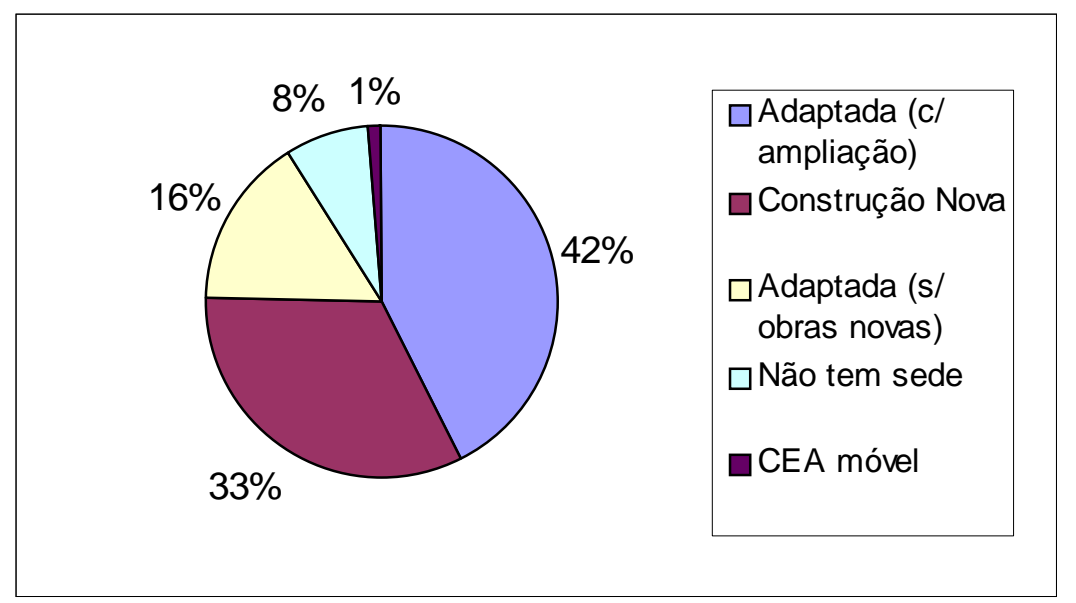

Figura 14 - Características do Edifício-sede dos CEAs

A observação da Figura 14 permite-nos concluir que a maioria dos CEAs estudados (42\%) dispõe de uma edificação-sede que foi adaptada, com necessidade de obras de ampliação, seguida de uma boa parcela de iniciativas (33\%) que apresentam construções novas, especialmente construídas para constituírem-se em sedes de CEAs. Via de regra CEAs vinculados à empresas privadas encaixam-se neste caso. Há, também, um percentual menor (16\%) de CEAs que afirmaram possuir sedes que são adaptações de espaços já disponíveis sem a necessidade de obras de ampliação. Um dado, porém, chama atenção no gráfico, que é referente aos $8 \%$ dos CEAs estudados que afirmaram não dispor de edificação-sede. Nestes casos, verificase que estas iniciativas utilizam espaços e de estruturas de outras instituições para apoiar no desenvolvimento de suas atividades. Por fim, verificou-se apenas uma iniciativa que se refere a um CEA móvel sobre o qual não obtivemos mais informações a respeito da sua "sede". 


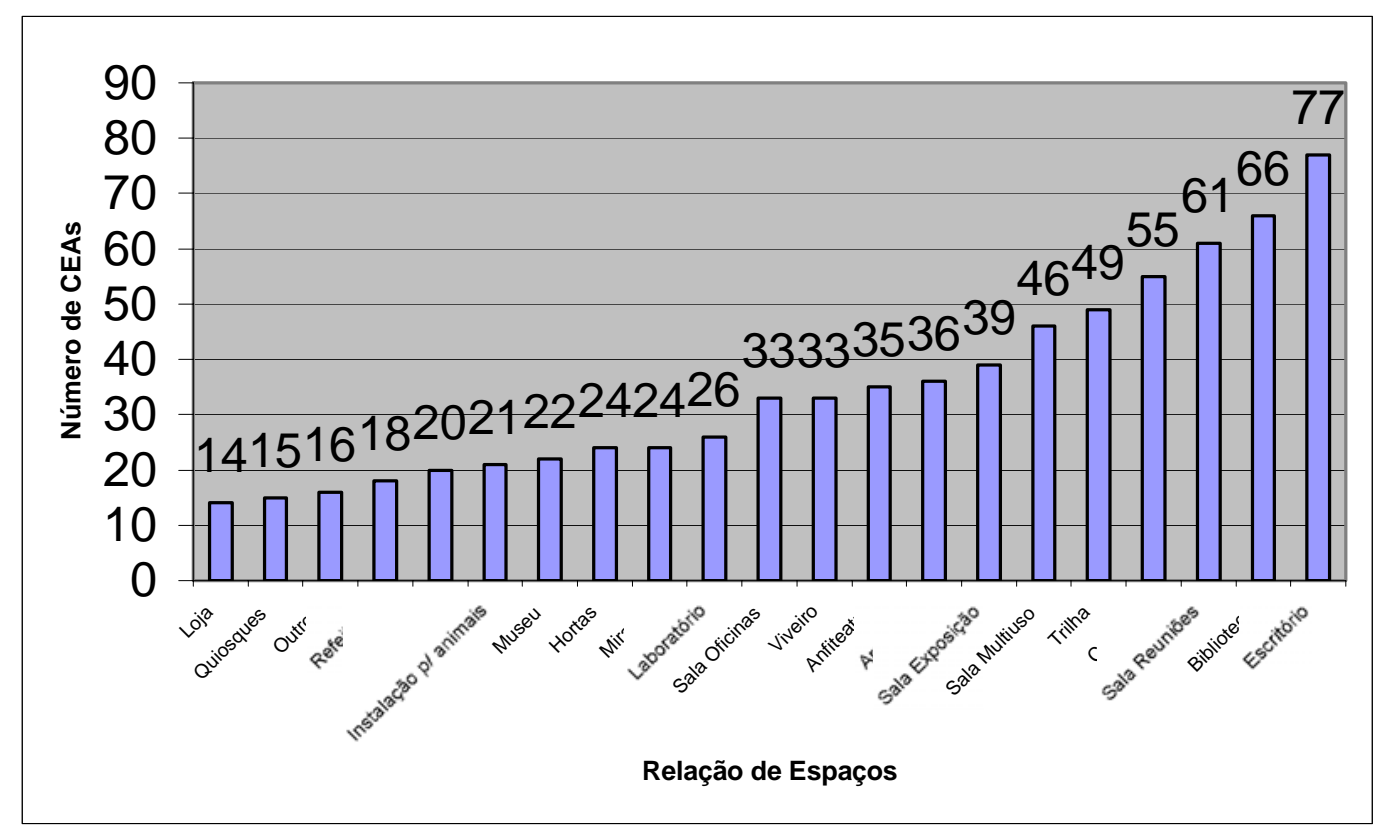

Figura 15 - Relação de Espaços disponíveis nos CEAs

Observa-se na Figura 15 que os espaços mais citados pelos CEAs levantados são: escritório (77 CEAs afirmam possuí-lo), biblioteca (66), sala de reuniões (61), cozinha (55), trilha (49), sala multiuso (49), sala de exposição (39) e anfiteatro (36). Destes 8 espaços mais citados, nota-se que há considerável distinção entre eles. Enquanto vislumbramos espaços comuns em outros tipos de instituições como sala de reuniões, bibliotecas, escritório, cozinha, auditórios, é possível também verificar a presença de espaços mais voltados a instituições de marcada vocação conservacionista, como as trilhas interpretativas e as salas de exposições. Merece destaque o dado de que praticamente a metade dos CEAs (49) afirma dispor de uma "sala multiuso", o que possibilita o desenvolvimento de uma série de atividades, tais como: palestras, bate-papos, oficinas, cursos, dinâmicas, dentre outras.

Verifica-se, também, que há uma presença acentuada de espaços marcadamente oriundos de pequenas propriedades rurais, bosques, áreas verdes, jardim botânico, zoológicos, dentre outros, como viveiros (33), mirantes (24), instalações para animais (21), museu (22), hortas (24) e quiosques (15). Há, ainda, uma minoria de CEAs que indicaram a presença de "lojas" nas suas dependências, 
como butiques, lojinhas de lembranças ou, até mesmo, um pequeno balcão com venda de produtos do CEA, da instituição promotora, de parceiros, etc.

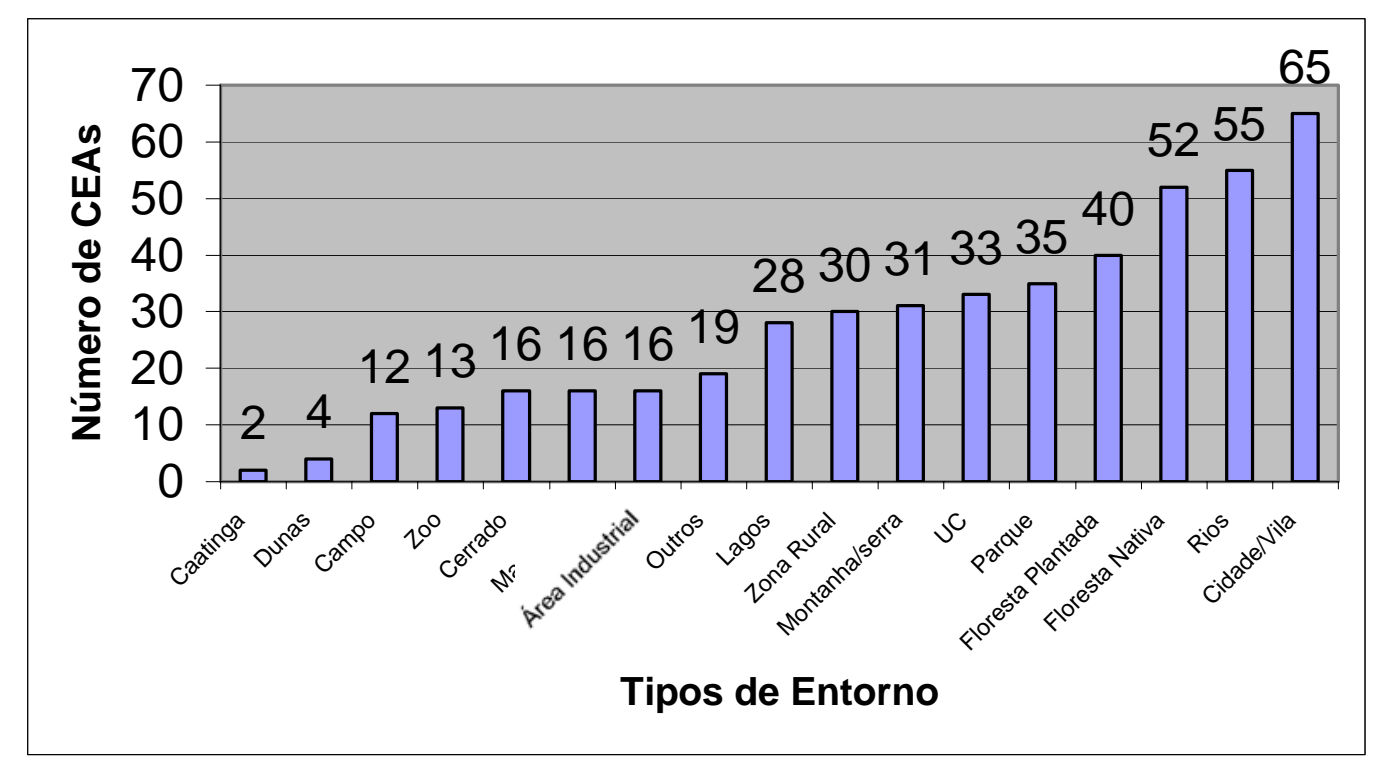

Figura 16 - Características do Entorno dos CEAs

Verificamos na Figura 16 que a maioria dos CEAs (65) aponta como entorno "cidades/vilas", o que indica que se tratam de iniciativas urbanas ou peri-urbanas, ou seja, localizadas em cidades ou no seu entorno próximo, como áreas rurais vizinhas a áreas urbanas. Cabe aqui explicitar que estamos adotando um conceito de "entorno" que considera tanto áreas localizadas próximas do CEA (vizinhança) como aquelas situadas dentro do próprio CEA.

Ainda analisando a figura, vislumbramos que pouco mais da metade dos CEAs afirma localizar-se em áreas com rios, córregos, riachos (55) e florestas nativas (52). Em pouco menos da metade dos CEAs verificou-se a presença de florestas plantadas (40), parques (35), Unidades de Conservação (33) e montanhas e serras (31). Numa minoria dos casos constatou-se que se tratam de iniciativas localizadas na zona litorânea (16), na região do cerrado (16), em zoológicos (13), próximo a dunas (4) e no bioma caatinga (2). 


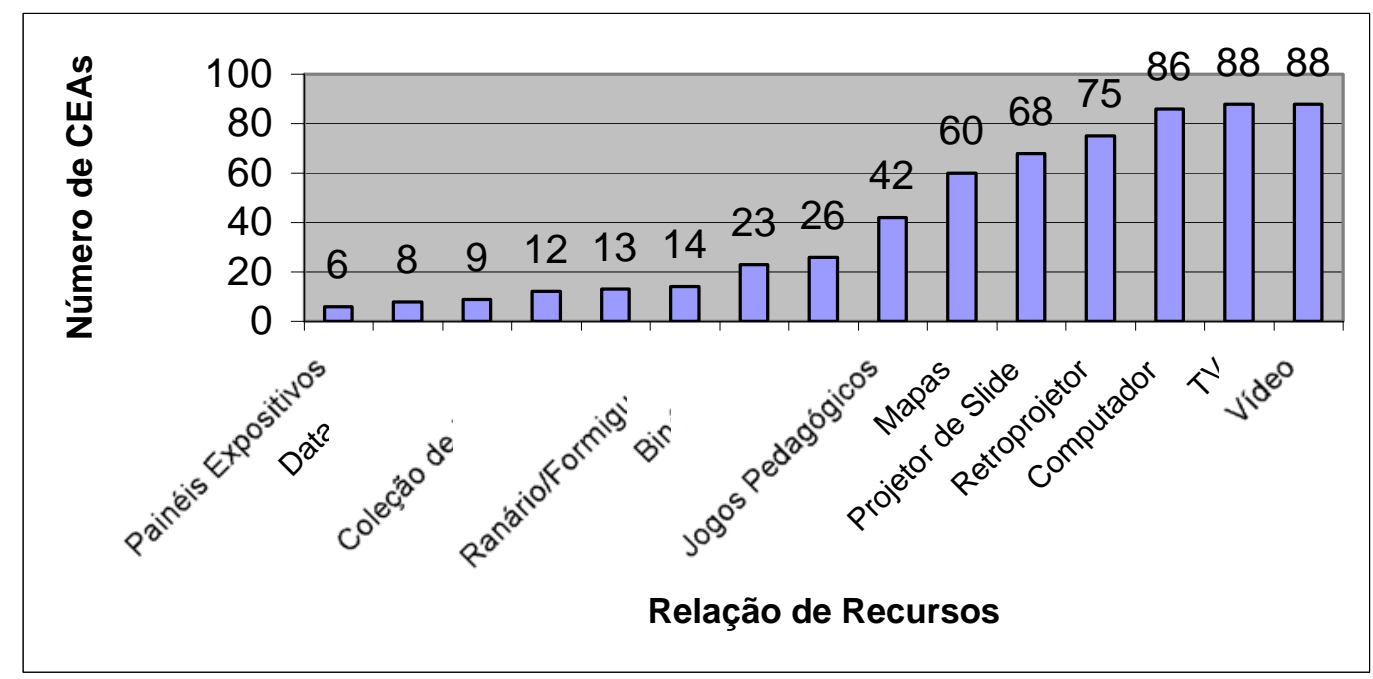

Figura 17 - Recursos disponíveis nos CEAs

Dos recursos explicitados na Figura 17, observamos uma predominância maior pela TV e vídeo-cassete (em 88 CEAs), computador (86), retroprojetor (75) e projetor de slides (60). Com menor freqüência verifica-se a disponibilidade de jogos pedagógicos (42), seguido de maquetes (26) e binóculos (23). Os demais, representando menos que $15 \%$ dos casos, referem-se a ranários e formigueiros (14), coleções de insetos (12), multimídia (9), data show (8) e painéis expositivos (6). $\mathrm{Na}$ categoria "outros" (13), encontrou-se diversas respostas como: herbários, equipamentos de análise de água, adereços de teatro, etc.

A observação dos dois recursos mais comuns em CEAs (TV e vídeo-cassete) permite-nos identificar uma atividade bastante trivial que eles ofertam para os públicos com os quais trabalham: exposição de vídeos, desde vinhetas, pequenos vídeos, curta metragens, até filmes, documentários, dentre outros. Em geral, utiliza-se desta atividade como preparação para outras atividades, como por exemplo: vídeo seguido de trilha, vídeo seguido de discussão, vídeo seguido de visita orientada. A presença destaca de computador(es) nos CEAs é também um ponto importante, porque permiteIhes diversas possibilidades, como a elaboração e produção de materiais diversos, desde simples folhetos até folders, cartazes, cartilhas, como também abre uma alternativa interessante de conexão com outras pessoas e outros CEAs, por meio da internet. Esta afirmação pode ser balizada por meio de uma análise comparativa de 
dois dados: 1) deste gráfico (17) que indica que 88 CEAs estudados, ou $87,1 \%$ da amostra dispõe de computador; 2) com o gráfico 6 que aponta que $82 \%$ dos CEAs dispõe de correio-eletrônico.

Numa observação mais pausada sobre a relação de recursos disponíveis em CEAs brasileiros percebemos que há muitas alternativas de adoção deste conjunto de recursos, dos quais os CEAs lançam mão, de acordo com a vocação do seu Projeto Político-Pedagógico, sua intencionalidade educacional, sua disponibilidade de equipe educativa, de recursos financeiros, etc. Cabe, ainda, explicitar que o fato de o CEA não dispor de verba não indica que ele venha a contar com um leque menor de recursos para apoiar suas atividades. Nestes casos a criatividade é um fator que conta muito e que pode proporcionar um "diferencial" para o CEA, como por exemplo, o uso de fantasias confeccionadas pelo próprio CEA em determinadas atividades, a reutilização de materiais, o estabelecimento de pequenas parcerias para viabilizar ações do CEA, dentre outros.

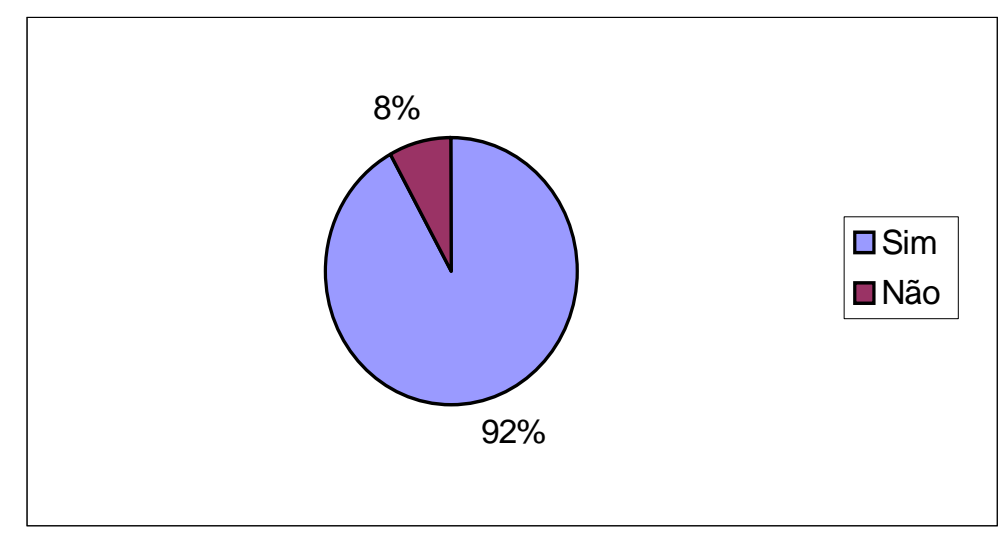

Figura 18 - Produção de materiais nos CEAs

A Figura 18 traz-nos um dado bastante interessante: de que a maioria dos CEAs da amostra produz materiais. Consideramos, aqui, tanto a elaboração do material, envolvendo sua concepção (conteúdos, diagramações, etc) quanto a sua produção propriamente dita (impressão, fotocópias, etc). Trata-se de um dado que surpreendeu, não somente em termos quantitativos (92\% da amostra), mas também qualitativos (considerando as diversas alternativas e vocações dos materiais 
produzidos). De fato, considerando este aspecto podemos visualizar na Figura seguinte, a diversidade de "tipos" de materiais produzidos por CEAs no Brasil, desde simples folhetos, folders e jornais até livros, manuais e CD-ROM que demandam um aparato tecnológico maior.

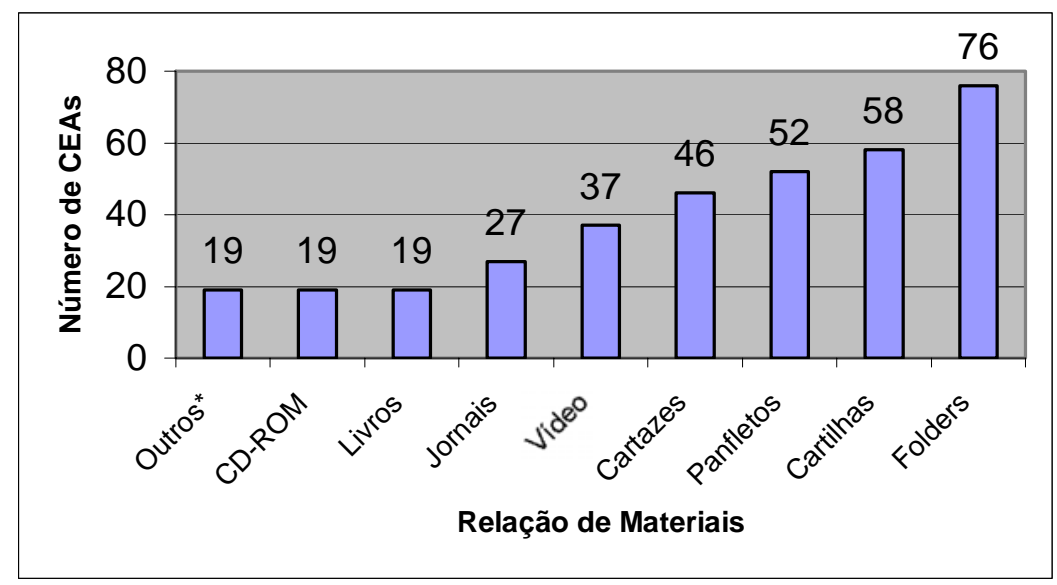

* apostilas, almanaque, Atlas, faixa, manual, álbum seriado, revista, quebra-cabeça, monografia, brindes, camisetas

Figura 19 - Materiais produzidos nos CEAs

Verifica-se na Figura 19 que a maioria dos CEAs afirma produzir folders (76), cartilhas (56) e panfletos (52), enquanto que pouco menos da metade indica a produção de cartazes (46) e vídeos (37). Há também, menos freqüente, CEAs que produzem jornais (27), livros, CD-ROM e diversos outros materiais (19), conforme indicado logo abaixo do gráfico.

Percebe-se que há produção de diversos tipos de materiais com vocação pedagógica, que se constituem em suportes nos processos educacionais voltados à questão ambiental deflagrados pelos CEAs. Ressaltamos a necessidade de estudos específicos sobre esta questão, buscando identificar e discutir concepções de EA presentes nestes materiais, assim como alguns de seus princípios e conceitos relacionados. Cabe, também, levantar a questão formal destes materiais: quais linguagens são utilizadas, para quais públicos, etc. 
C) Bloco 3 - Dados do Público Atendido

Neste bloco veremos quais os tipos de público que os CEAs atendem, de onde eles vêm, como ficam sabendo da existência do CEA e qual a estimativa de pessoas/ano.

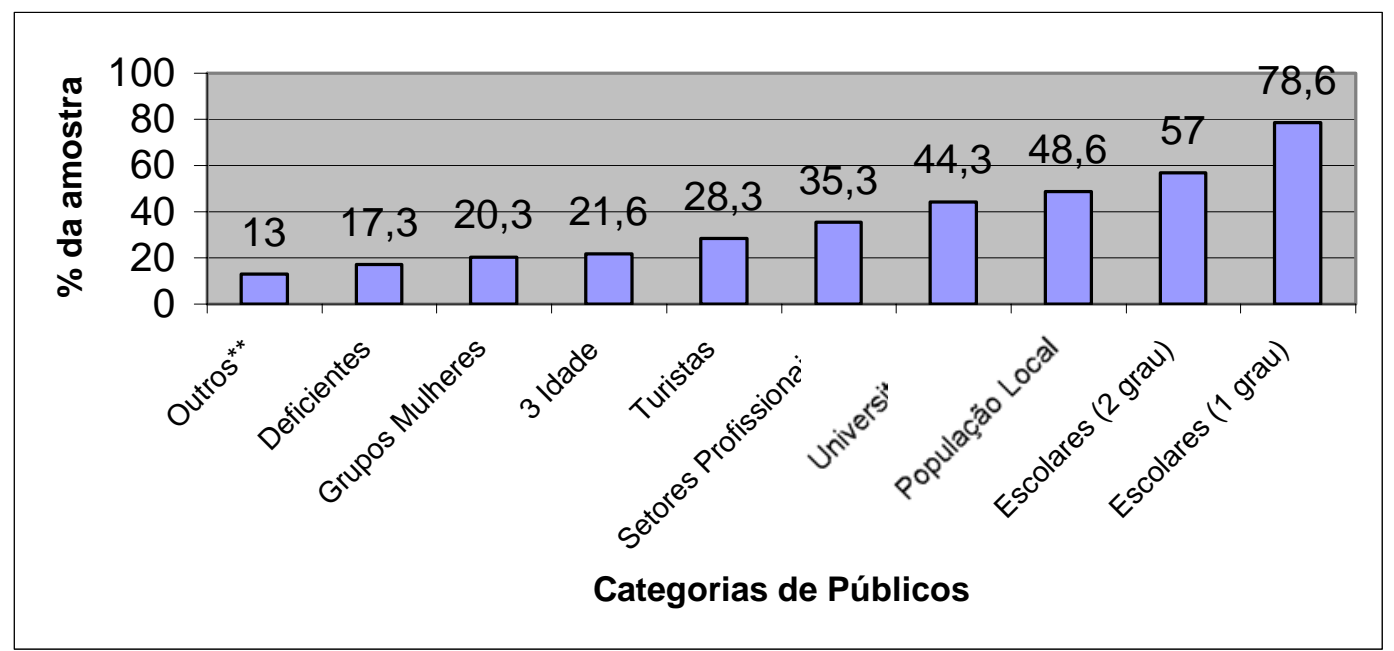

* técnicos ambientais, professores, pesquisadores, agrônomos

** empresários, ONGs, extrativistas, pescadores

Figura 20 - Público atendido pelos CEAs

Visualiza-se na Figura 20 que a grande maioria dos CEAs em questão atua diretamente com o segmento escolar, com especial destaque para os Ensinos Fundamental e Médio. Também aparece o segmento da "População Local" (48,6\%), Estudantes Universitários (44,3\%) e Setores Profissionais $(35,3 \%)$ de áreas ligadas à temática ambiental e/ou educacional (técnicos de órgãos de gestão ambiental, agrônomos, professores e pesquisadores). Em menor freqüência aparece o segmento "turistas" (28,3\%), "Terceira Idade ${ }^{54 "}(21,6 \%)$, "Grupo de Mulheres/Donas de Casa" (20,3\%), "Deficientes ${ }^{55 "}$ (17,3\%), e "Outros" (13\%), correspondendo a empresários, ONGs, extrativistas e pescadores.

\footnotetext{
${ }^{54}$ Preferimos a adoção do termo "Melhor Idade", mas pelo fato do termo "Terceira Idade" ter constado no questionário 1, o mesmo foi mantido na apresentação dos resultados.

${ }^{5}$ Da mesma forma que o termo anterior, temos preferência por "Portadores de Necessidades Especiais", mas como o termo adotado no questionário 1 foi "Deficiente" preferiu-se mantê-lo agregado a esta ressalva.
} 
Nota-se, ainda, que os CEAs concentram sua ação junto ao segmento da educação formal (escola e universidade), mas também com a presença de segmentos da sociedade (não formal). De fato, verificamos uma breve tendência ao aumento no atendimento à públicos não ligados ao ensino formal, como setores comunitários (mulheres, melhor idade, turistas, pescadores, agricultores, etc). Temos insistido na "bandeira" de que os CEAs devem buscar atuar junto à públicos diversificados, com especial atenção para a não especialização no segmento formal do ensino.

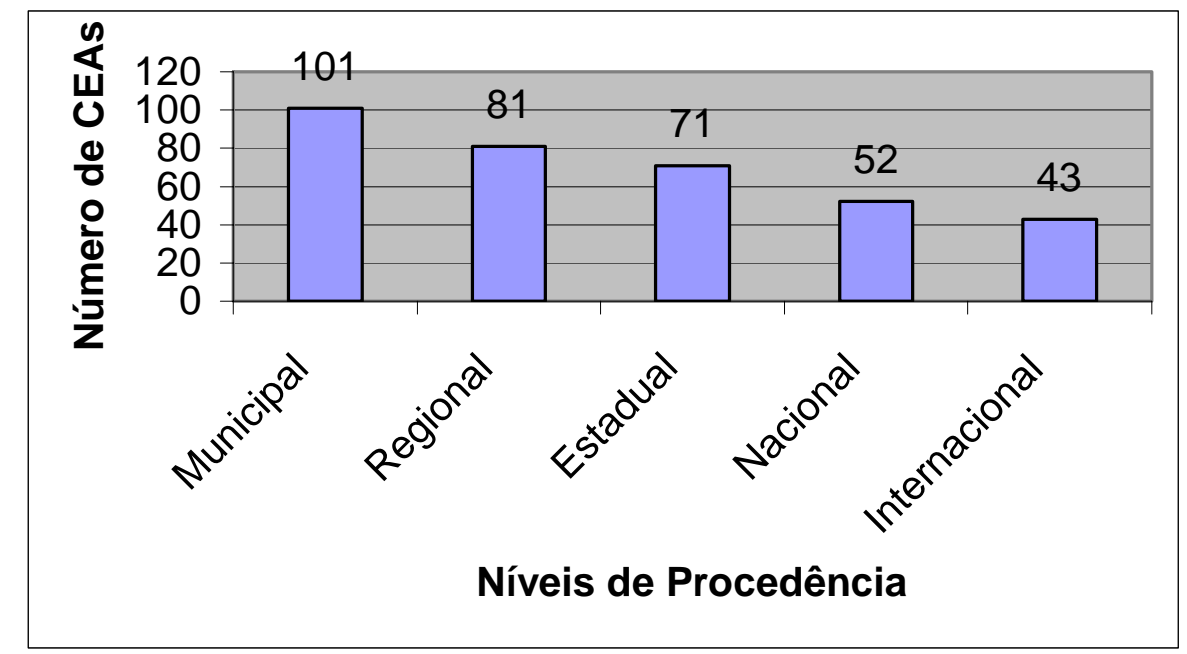

Figura 21 - Procedência do público atendido

No que diz respeito à procedência do público que os CEAs atendem, verificouse que todos trabalham com pessoas provenientes do próprio município. Na medida em que vai distanciando-se do município verifica-se uma redução no número de CEAs que atendem pessoas com este nível de procedência. Quando observamos a segunda coluna, relativa à procedência regional, verifica-se que 81 CEAs afirmam atuar com pessoas da própria região. Adota-se aqui o conceito de região numa perspectiva menos ampla do ponto de vista espacial do que os adotados para denominar as cinco regiões brasileiras (Norte, Nordeste, Sul, Sudeste e Centro-Oeste). Entende-se, neste caso, como sendo "região" um raio de abrangência imediatamente próximo ao município onde o CEA está situado. Pode ser feita a leitura aqui de bacias 
hidrográficas, regiões administrativas estaduais, dentre outros "recortes", somente para visualizarmos a dimensão do termo.

Quanto à procedência estadual, ou seja, da mesma Unidade Federativa do CEA, foram obtidas 71 respostas afirmativas no conjunto da amostra, enquanto que, praticamente, a metade (52 CEAs) respondeu receber públicos de outras Unidades Federativas brasileiras. Quanto ao público de procedência internacional, 43 CEAs afirmaram trabalhar com este público. Os países de origem, entretanto, não foram levantados.

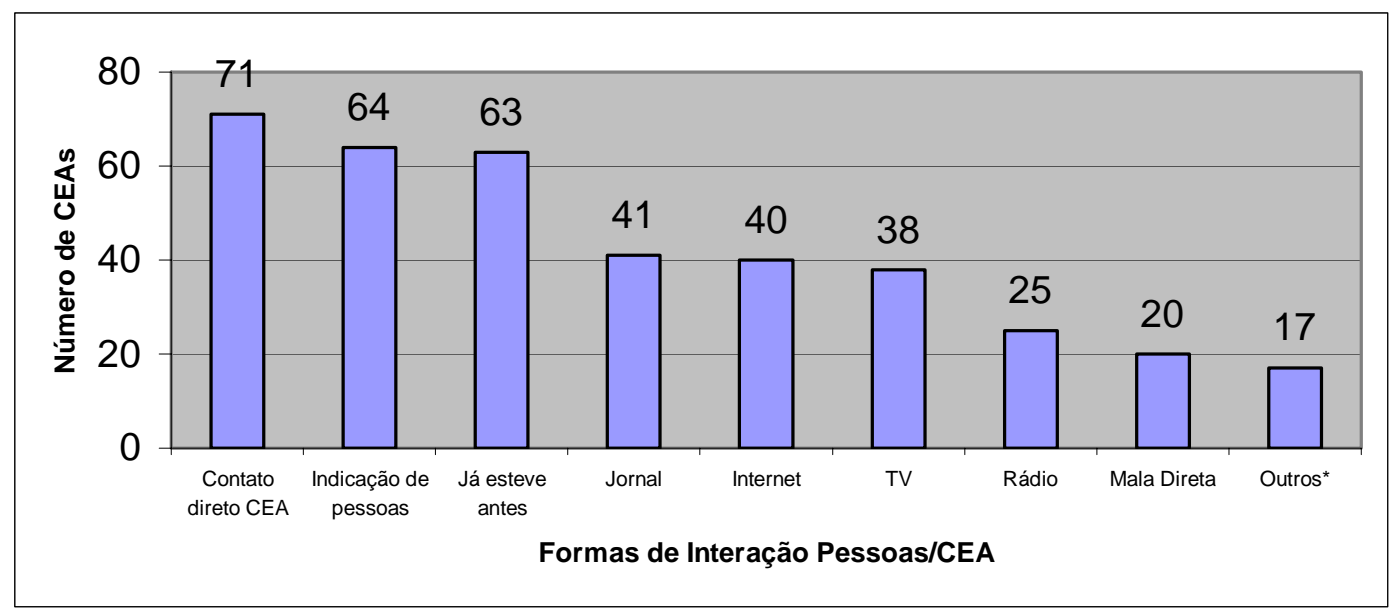

Figura 22 - Estratégias de divulgação do CEA

A visualização da Figura 22 indica que a maioria dos CEAs dispõe de três estratégias para estabelecer comunicação e interação com os segmentos com os quais pretende trabalhar: a) por meio de contato direto com os públicos que pretende trabalhar (71 CEAs); b) através da indicação de pessoas (64 CEAs); e c) retorno destes públicos ao CEA, uma vez que eles já participaram de suas atividades (63 CEAs).

Nota-se, também, um considerável número de CEAs que afirmam a adoção de outros meios de comunicação para divulgar suas ações para a sociedade, como jornal (41 CEAs), internet (40), TV (38) e rádio (25). No primeiro deles, inclui-se desde jornais municipais até aqueles de produção própria do CEA. Quanto à adoção da internet, a marca encontrada surpreendeu, sendo o uso da internet cada vez mais comum no 
meio da educação ambiental no país, mas não existiam dados sobre a sua utilização em Centros de Educação Ambiental e entre eles e outros segmentos da sociedade. Também surpreendeu a marca de 38 CEAs que utilizam a TV para divulgar suas ações aos públicos com os quais pretendem trabalhar, através da participação em programas, entrevistas, matérias feitas em CEAs, em eventos com cobertura da mídia televisiva, etc. Quanto ao rádio, percebeu-se uma correlação inversa entre a utilização do rádio e a da internet. Em CEAs onde adota-se o rádio como uma das estratégias de comunicação o mesmo tende a não ser mencionado como alternativa de comunicação. A explicação encontrada para a questão refere-se à realidade onde o CEA está inserido, em geral em locais desprovidos de telefone, internet e situados na zona rural. Estes parecem ser os ingredientes recorrentes para CEAs que se utilizam do rádio como uma das suas principais estratégias de comunicação e de divulgação da sua "existência" e do seu "cardápio" de atividades.

Encontrou-se, ainda, uma minoria de CEAs (17) que adota outras estratégias, sobretudo por meio da realização de campanhas e pela implementação de projetos, ambas oportunidades para atrair pessoas e divulgar suas ações.

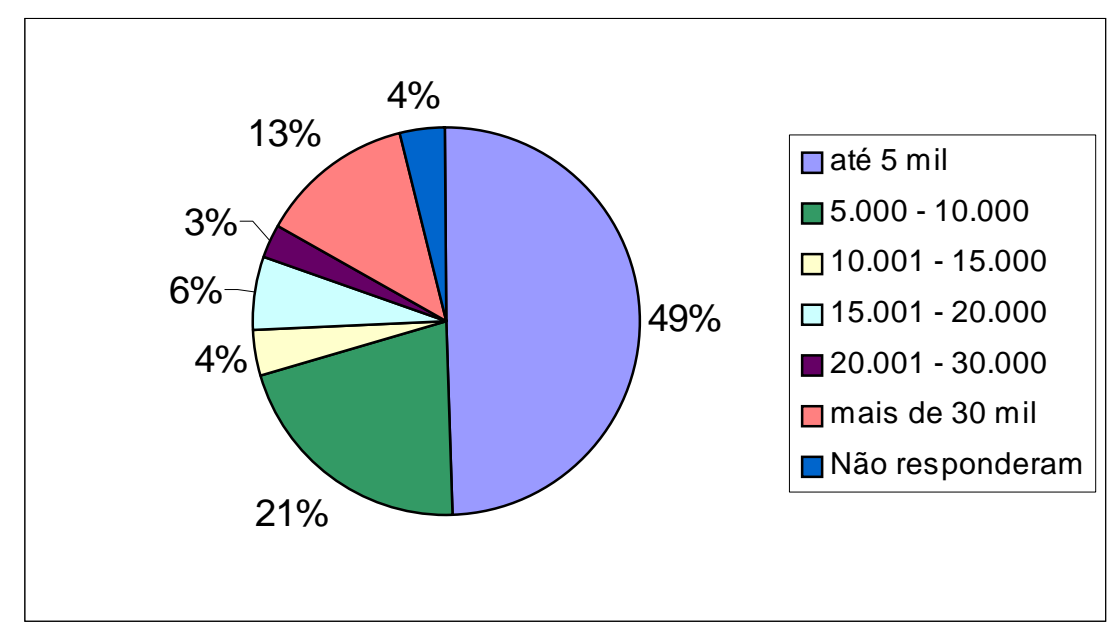

Figura 23 - Público Atendido anualmente

No que diz respeito à estatística de número de pessoas atendidas por ano, verifica-se, na Figura 23, que a grande maioria dos CEAs em questão (70\%) atende até 10 mil pessoas neste período, sendo que quase a metade da amostra (49\%) 
encontra-se no patamar de até 5 mil. Parece uma marca tímida, mas se fizermos um cálculo simples veremos que resulta numa média aproximada de 14 pessoas/dia que o CEA atende.

Entre a faixa de 10 mil até 30 mil pessoas por ano, verifica-se percentuais pequenos (representando $13 \%$ na soma das três classes), o que indica que há uma leve polaridade no que diz respeito às estimativas de públicos atendidos pelos CEAs da amostra. Se há um pólo, nas classes até de 10 mil pessoas por ano, verifica-se um outro na classe de mais de 30 mil pessoas por ano (13\%). É provável que estes casos refiram-se a CEAs que optam por ofertar atividades de curta duração, sobretudo as tão conhecidas "visitas orientadas" e registram suas estatísticas em "livros de visitas".

Ao fazer outro cálculo rápido, considerando os 101 CEAs em questão e multiplicando cada um deles pelas suas médias de público por ano, alcançamos a marca de pouco mais de um milhão de pessoas que estes CEAs atendem por ano, o que dá uma média de, praticamente, 10 mil pessoas/ano/CEA.

Independentemente do número de pessoas por ano que os CEAs atendem é preciso que se busque explicitar elementos que possibilitem qualificar a atuação deles. De que forma cada uma das milhares de pessoas que passam pelas suas dependências, participam das suas atividades e colaboram com seus projetos estão se beneficiando disto? Quais são as contribuições que o CEA pode aportar aos públicos com os quais atua?

\section{D) Bloco 4 - Equipe Pedagógica}

Neste bloco veremos questões relacionadas à média de pessoas nas equipes educativas dos CEAs da amostra e áreas de formação dos membros da equipe.

A observação da Figura 24 permite-nos visualizar que há uma média predominante de composição das equipes educativas dos CEAs de 4 a 7 pessoas (em $33 \%$ dos casos). Na seqüência, observa-se uma média de 2 a 3 pessoas (em $26 \%$ dos casos), seguida pela marca de mais de 10 pessoas compondo a equipe pedagógica de $15 \%$ dos CEAs estudados. 


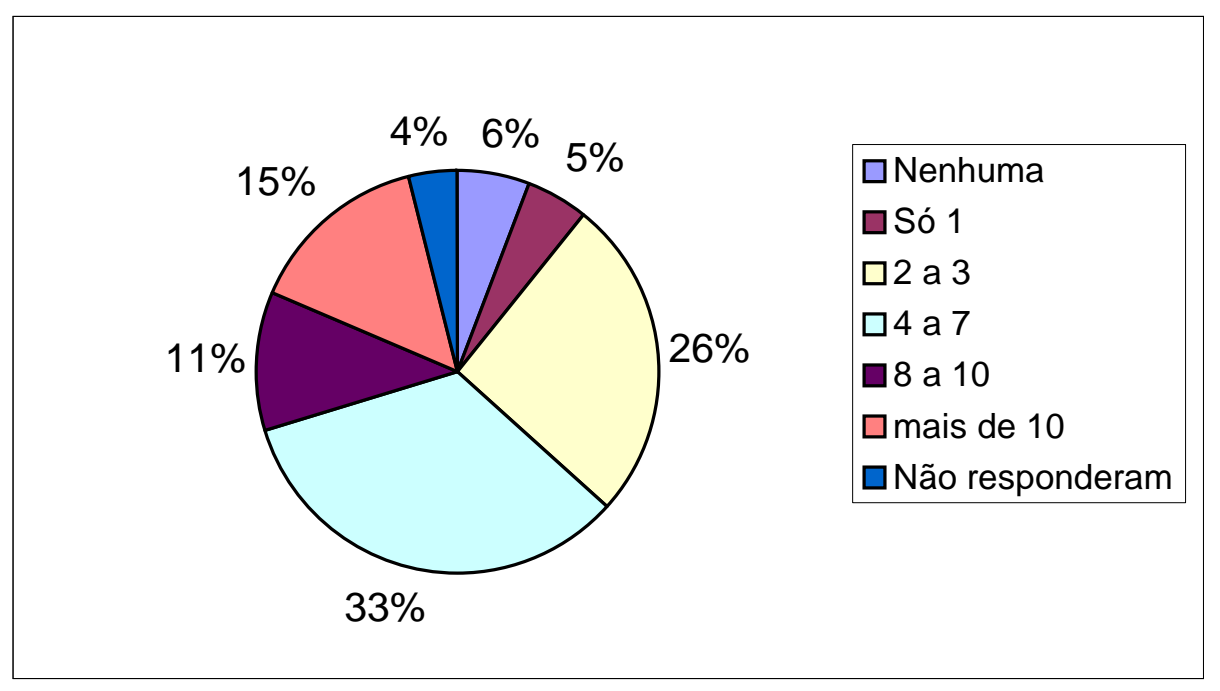

Figura 24 - Membros da equipe educativa dos CEAs

Desenvolvendo-se um cálculo simples chega-se a uma marca de, aproximadamente, 600 pessoas trabalhando com remuneração nos CEAs considerados neste estudo, o que nos fornece uma média geral de quase 6 pessoas nas equipes dos CEAs brasileiros. Considerando-se que a média de público é de 14 pessoas por dia, pode-se dizer que há um número bastante razoável de profissionais para atendê-los. Entretanto, é necessário ressaltar que, por tratar-se de uma média, encontramos casos dramáticos de CEAs que ou dispõem de somente uma pessoa atuando com remuneração na equipe ou não possuem nenhuma pessoa com esse "status", correspondendo os dois a 11\% da amostra. Além disto, esta média precisa ser analisada a partir de outros parâmetros, como o número de horas de dedicação de cada profissional, a formação dos mesmos, as atividades que desempenham, dentre outros.

É, sobretudo, sobre estes CEAs que estudos e análises mais aprofundados são necessários, de modo a identificar fatores que levam a essa baixa absorção de pessoas para atuarem nas equipes educativas de CEAs. É preciso que se combata a realidade das "euquipes", buscando meios para contornar a situação, seja por meio de captação de recursos, estabelecimento de parcerias, etc. 


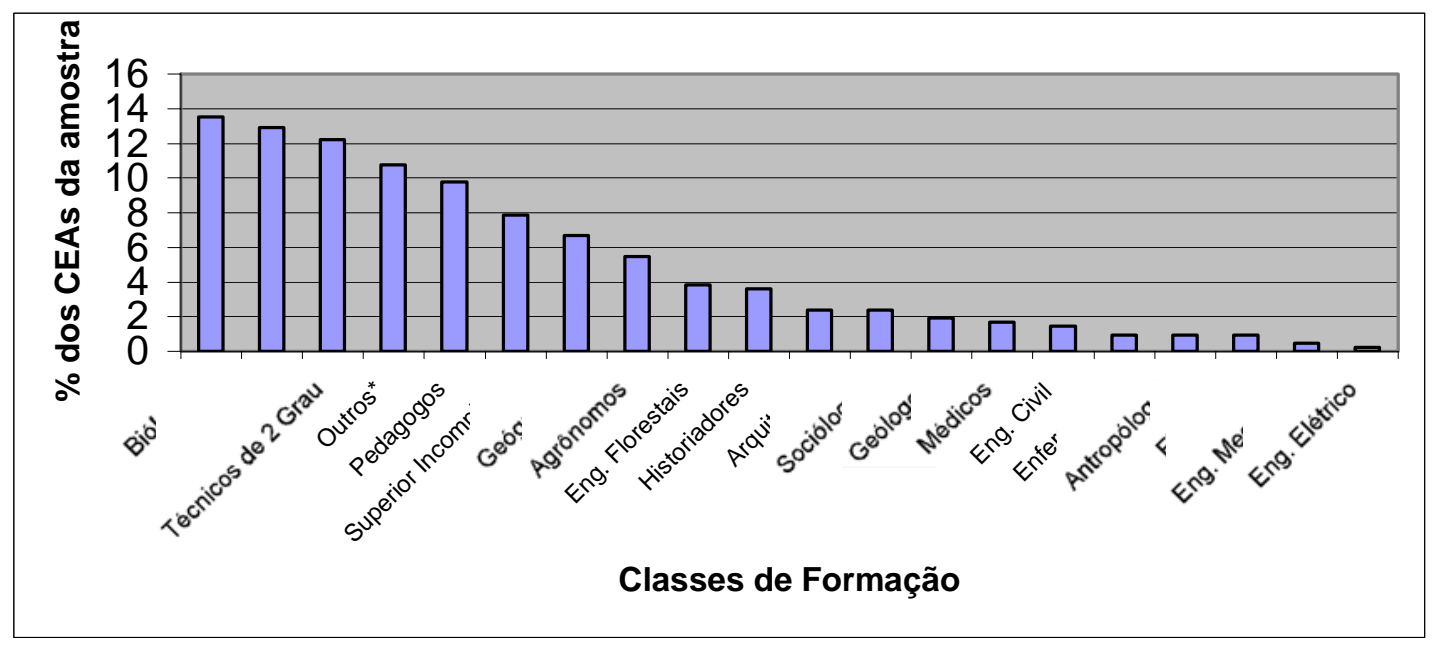

Figura 25 - Formação dos membros das equipes educativas

Uma primeira visualização da Figura 25 permite-nos perceber a diversidade de áreas de formação presentes no conjunto das equipes educativas dos CEAs estudados. Áreas dos campos de humanidades (educação, pedagogia, sociologia, história, antropologia, filosofia, dentre outras); de ciências naturais (biologia, agronomia, engenharia florestal) e de exatas (engenharias civil, mecânica, elétrica, arquitetura e outras).

Apesar de observar-se esta diversidade de áreas percebe-se, facilmente, o predomínio de algumas formações em detrimento de outras, como ocorre com os biólogos (13,5\%), com os educadores (12,9\%), com os técnicos de $2^{\circ}$ grau $(12,2 \%)$ e com os pedagogos $(9,8 \%)$. Há uma considerável diversidade de áreas de formação na classe "outros", a qual corresponde a $10,8 \%$ da amostra e compreende: advogados, jornalistas, oceanógrafos, físicos, matemáticos, veterinários, zootecnistas, gestores ambientais, artistas plásticos, bibliotecários, designers, religiosos, economistas, nutricionistas, assistentes sociais e turismólogos.

Há uma marca $(7,9 \%)$ também considerável de estudantes universitários atuando em CEAs, na classe "superior incompleto", o que pode constituir-se em estratégia do CEA para mobilizar mão de obra a custos mais baixos (com remuneração do tipo "bolsa"). 
E) Bloco 5 - Atividades Desenvolvidas

Neste bloco veremos quais as atividades mais oferecidas pelos CEAs e suas respectivas combinações; quanto tempo duram; quais os temas trabalhados e quais são as formas de pagamento das atividades.

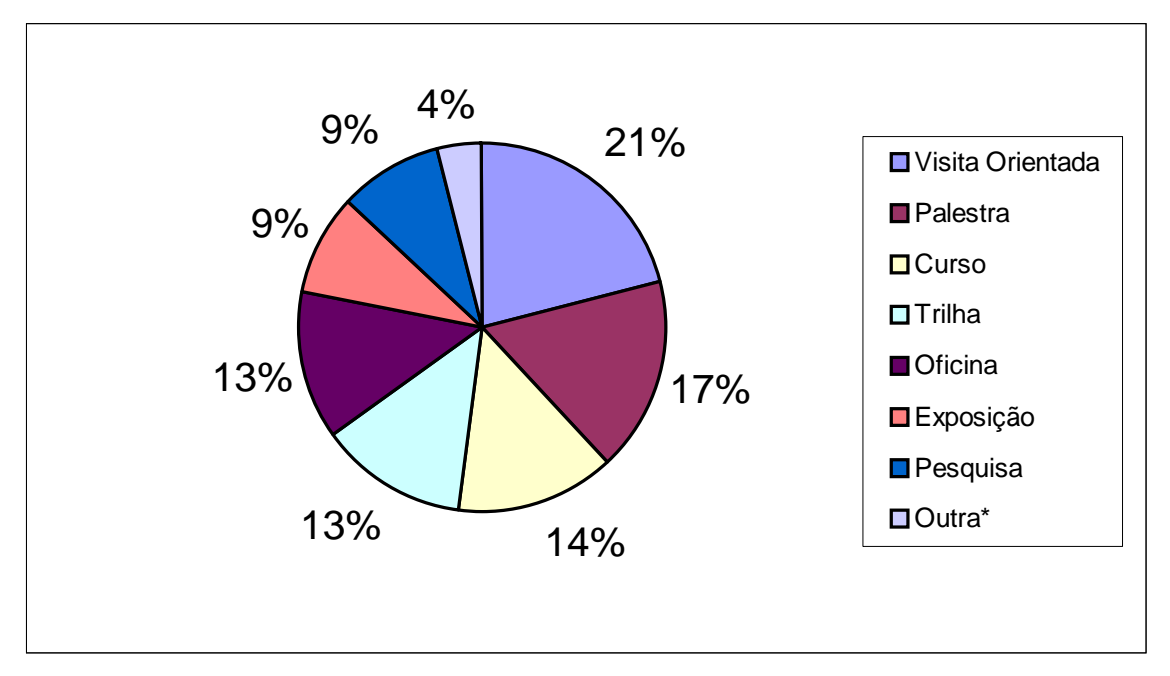

* teatro, eventos, sarau, reunião, consultoria, dinâmica de grupo, atividade lúdica

Figura 26 - Atividades mais freqüentemente realizadas pelos CEAs

Quanto ao leque de atividades oferecidas pelos CEAs, verifica-se o predomínio pelas visitas orientadas (21\%), palestras (17\%), cursos (14\%), trilhas e oficinas (13\%). De fato, as intervenções mais freqüentes nestes CEAs são também observadas na Figura 26, a qual traz as combinações de atividades mais comuns. Com exceção dos cursos, as demais intervenções mais freqüentes, em geral, configuram-se como sendo de curta duração, entendida aqui como aquelas com duração que varia entre algumas horas (2 ou 3) até uma jornada diária de trabalho (8 a 12 horas). 


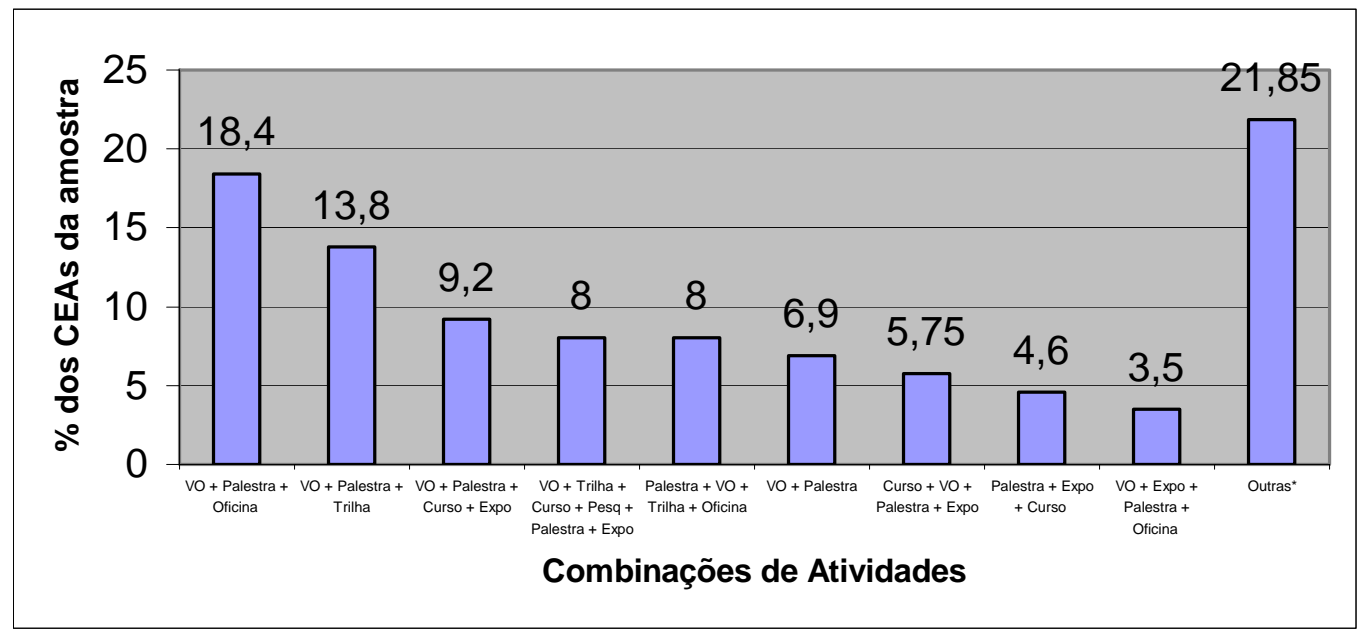

Figura 27 - Combinações de atividades mais freqüentes dos CEAs

Verifica-se na Figura 27 que a combinação mais freqüente nos CEAs estudados $(18,4 \%)$ é Visita Orientada (VO) seguida de Palestra e de Oficina. Destaque para a presença da atividade "Visita Orientada" na grande maioria das combinações expostas no gráfico (9 das 10). A Classe "Outras" traz uma relação de 12 combinações, com percentual médio de $2 \%$, quais sejam: VO + Oficina + Curso + Palestra; VO + Pesquisa + Trilha + Palestra + Curso + Oficina; Curso + Palestra + Oficina; Curso + Oficina + Pesquisa; Exposição (Expo) + Palestra + VO; Pesquisa + Curso + Palestra; Trilha + Palestra + Dinâmica; VO + Expo; VO + Atividade Lúdica + Atividade de Interpretação; Palestra + Vo + Trilha + Pesquisa + Curso + Dias de campo; Expo + Palestra + Curso + Oficina + Pesquisa; Trilha + Teatro.

Constatou-se que os CEAs apresentam um total de 21 combinações de atividades. Embora pareça haver diversidade de combinações, um olhar mais atento a este cenário possibilita visualizar que há pouca variação de tipos nas atividades mais freqüentemente ofertadas. A grande maioria delas gira em torno de Visitas Orientadas, Palestras, Oficinas, Trilhas, Exposições e Cursos (e algumas das possíveis combinações daí decorrentes). De fato, são estas seis atividades que compõem o "cardápio" principal dos CEAs estudados. 


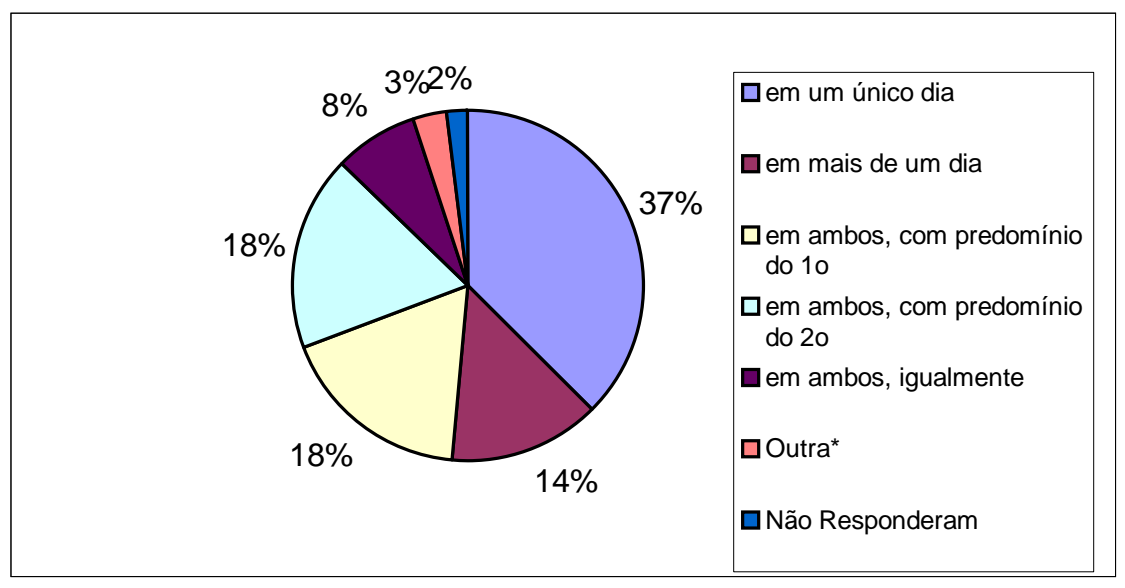

* mais longa: durante o semestre ou ao longo de todo o ano

Figura 28 - Duração das atividades desenvolvidas nos CEAs

Visualiza-se na Figura 28 que há predominância pelo desenvolvimento de atividades de curta duração ( $37 \%$ dos CEAs) consideradas, aqui, com sendo aquelas com duração entre uma hora e uma jornada diária (10 - 12 horas). Se observarmos, ainda, que $18 \%$ dos CEAs da amostra afirmam desenvolver atividades de curta e de longa duração, mas com predomínio das primeiras, pode-se dizer que o percentual de CEAs "especializados" na oferta de atividades de curta duração sobe para $55 \%$ o que indica que a maioria dos CEAs prefere este tipo de atividades.

Em contrapartida, verifica-se que 14\% dos CEAs da amostra afirmam realizar atividades de mais de um dia de duração. Considera-se, aqui, intervenções como cursos de vários dias, projetos e exposições. Acompanhado a este dado, observa-se $18 \%$ dos CEAs que ofertam atividades de durações curta e longa, com predomínio para a segunda, o que nos permite chegar a um percentual de $32 \%$, fato que merece destaque. 


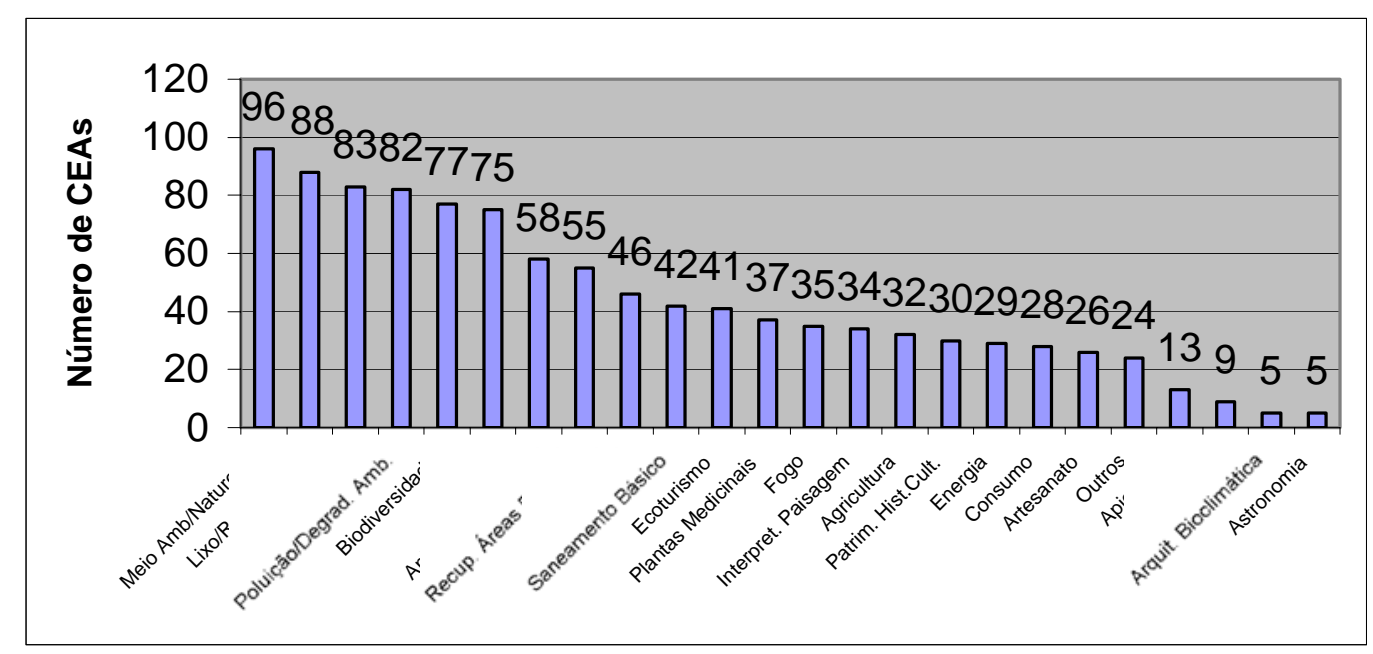

Figura 29 - Temas trabalhados nos CEAs

Dos vinte e quatro temas listados, podemos visualizar na Figura 29 quatro blocos distintos de acordo com a freqüência de aparição. O primeiro, englobando os que são majoritariamente trabalhados nos CEAs (de 75 a 96 CEAs), é composto pelos seguintes temas: meio ambiente/natureza, lixo/reciclagem, água, poluição/degradação ambiental, biodiversidade e árvores. O segundo bloco é formado por temas também muito freqüentes, abarcando de 41 a 58 CEAs, compreendendo: animais silvestres, recuperação de áreas degradadas, solo/erosão, saneamento básico e ecoturismo. No terceiro bloco tem-se os temas menos freqüentes nos CEAs estudados (de 24 a 37 CEAs), como: plantas medicinais, fogo, interpretação da paisagem, agricultura, patrimônio histórico-cultural, energia, consumo, artesanato e outros. Na classe "outros" há a presença de temas como: desenvolvimento sustentável, educação ambiental e valores éticos. Por fim, no quarto bloco tem-se os temas pouco citados pelos CEAs (de 5 a 13 CEAs): apicultura, pecuária, arquitetura bioclimática e astronomia.

Observando os blocos 1 e 2 tem-se uma visão geral dos temas preferencialmente trabalhados pelos CEAs que, via de regra, estão focados em torno de elementos da natureza (água, animais, biodiversidade, árvores e ecoturismo), em problemas ambientais e/ou nas respectivas estratégias de enfrentamento (poluição, erosão, recuperação de áreas degradadas, lixo/reciclagem e saneamento básico). No bloco três, percebe-se que há uma espécie de "especialização" de temas abordados 
preferencialmente por determinados "tipos" de CEAs, enquanto que outros não, como: plantas medicinais, fogo, interpretação da paisagem, agricultura, patrimônio históricocultural, energia, consumo e artesanato. Percebe-se que são temas voltados a questões rurais e agrícolas, de um lado e culturais de outro. No quatro bloco notamos, também, a presença de temas direcionados a alguns "tipos" de CEAs, como: apicultura, pecuária, arquitetura bioclimática e astronomia, embora consideremos que o tema "arquitetura bioclimática" tenha potencial de ser "explorado" na maioria dos CEAs, porque traz elementos importantes para o CEA refletir sobre seu papel demonstrativo e como instrumento pedagógico.

\section{F) Bloco 6 - Projeto Político-Pedagógico}

Neste bloco abordaremos questões relativas a presença de Projetos Políticos Pedagógicos nos CEAs analisados, seguidos dos motivos elencados de não se ter um projeto; quais as concepções dadas a estes projetos e quais são as formas de avaliação das atividades e do CEA como um todo. Também veremos como os CEA que trabalham o tema "biodiversidade" o concebem.

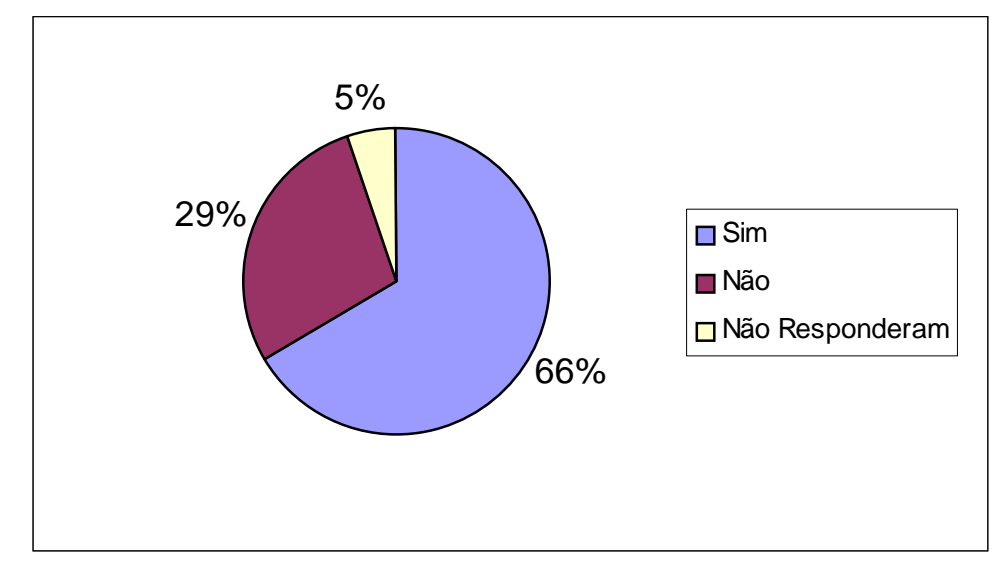

Figura 30 - Projeto Político-Pedagógico nos CEAs

A Figura 30 aponta-nos que a maioria dos CEAs em questão (66\%) afirmam possuir um Projeto Político Pedagógico, nas suas mais diversas denominações: programa pedagógico, projeto pedagógico, etc, enquanto que $29 \%$ responderam não possuí-lo. Veremos no gráfico a seguir quais os motivos que levam este percentual de 
CEAs a não possuir um Projeto Político Pedagógico que norteie e oriente sua ação. Ainda tivemos 5\% de CEAs que não responderam a questão.

Já vimos a importância do Projeto Político Pedagógico para CEAs, elemento considerado como parte da essência de qualquer iniciativa que almeja constituir-se num Centro de Educação Ambiental. Embora verifiquemos que a maioria (66\%) dos CEAs menciona dispor deste elemento, percebemos que um percentual considerável de iniciativas que não dispõe. Se consideramos que um PPP significa a presença de um eixo orientador do CEA como um todo, e que seconstitui elemento essencial de qualquer CEA, podemos então inferir que dos 101 CEAs que compõem a amostra deste estudo, somente $66 \%$ podem ser de fato considerados como tal. Obviamente que para ser um CEA conta muito mais a observação de um conjunto de elementos do que simplesmente procedermos a um check list de itens indispensáveis. No entanto, esta discussão precisa ser estimulada junto aos CEAs em atividade no Brasil com urgência. É preciso "combater" o surgimento de novas iniciativas que não possuam qualquer direcionamento pedagógico ou definição de estratégias e de rumos para onde - CEA quer seguir, haja vista que na prática observam-se diversas iniciativas que foram implantadas sem qualquer planejamento político e pedagógico e que não encontram-se mais em atividade ou enfrentam dificuldades para prosseguirem.

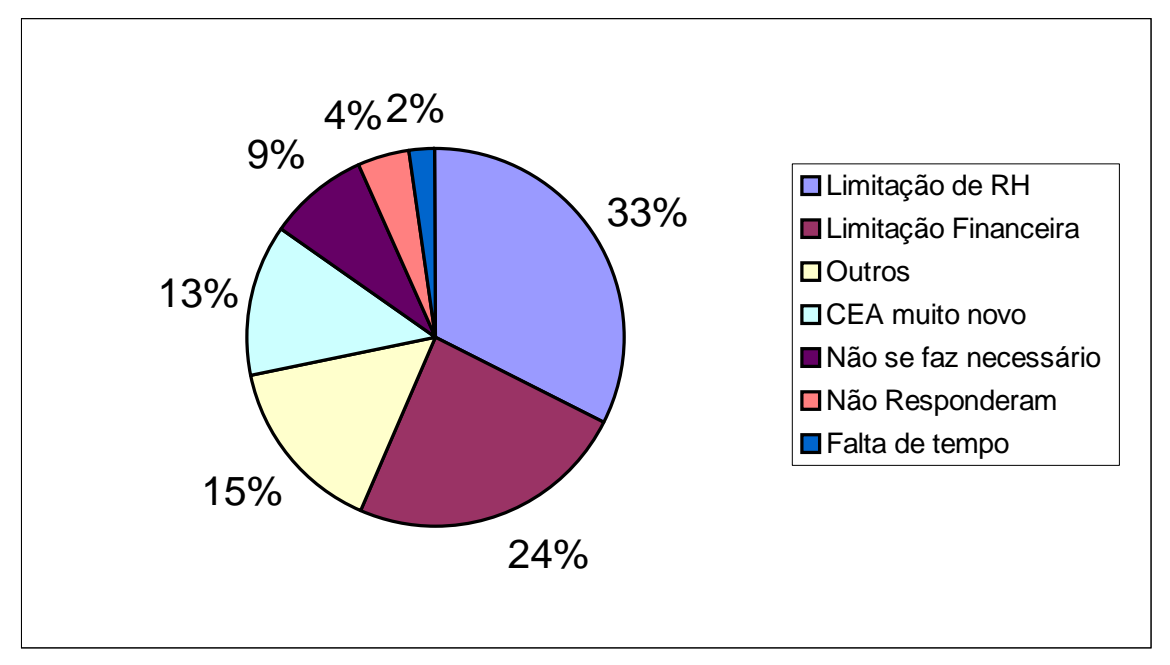

Figura 31 - Alegações para não existência de um PPP 
A Figura 31 indica-nos que os dois principais fatores que inviabilizam a existência de um PPP, nos 29\% dos CEAs que responderam não dispor de um são: limitação de recursos humanos (33\%) e financeira (24\%). Na questão de pessoal, considera-se tanto a carência em termos quantitativos e qualitativos, como por exemplo, pessoas na equipe que têm experiência na construção de Projetos PolíticoPedagógicos. O fator financeiro é também apontado como motivo que impossibilita a constituição de um PPP para o CEA. Há, ainda, a classe "outros" (15\%) que engloba respostas como: PPP existe mas está sendo reelaborado; PPP precisa ser rediscutido, dentre outras. Na seqüência verificou-se que em $13 \%$ dos casos trata-se de CEAs recém criados e que não dispõe de um PPP, enquanto que $9 \%$ afirmam que um PPP não se faz necessário para o CEA. Justamente sobre estes dois dados é que nos cabe tecer algumas considerações. Em primeiro lugar, percebe-se que há uma "fatia" de CEAs no Brasil que vem sendo criados sem qualquer discussão prévia de questões como: "para onde caminhar?"; "qual a missão do CEA?"; "porque criar um CEA?", dentre outras. Confere-se a estes CEAs muito mais um caráter construtivo do que pedagógico, o que é bastante preocupante. Em segundo lugar, visualiza-se que há CEAs em funcionamento, recém criados ou não, que consideram que um PPP não se faz necessário. Aqui, entendemos que preocupação é ainda maior, porque há uma compreensão distinta da que estamos considerando como sendo um CEA. Cabe a questão: nestes casos, o que se considera como sendo um CEA?

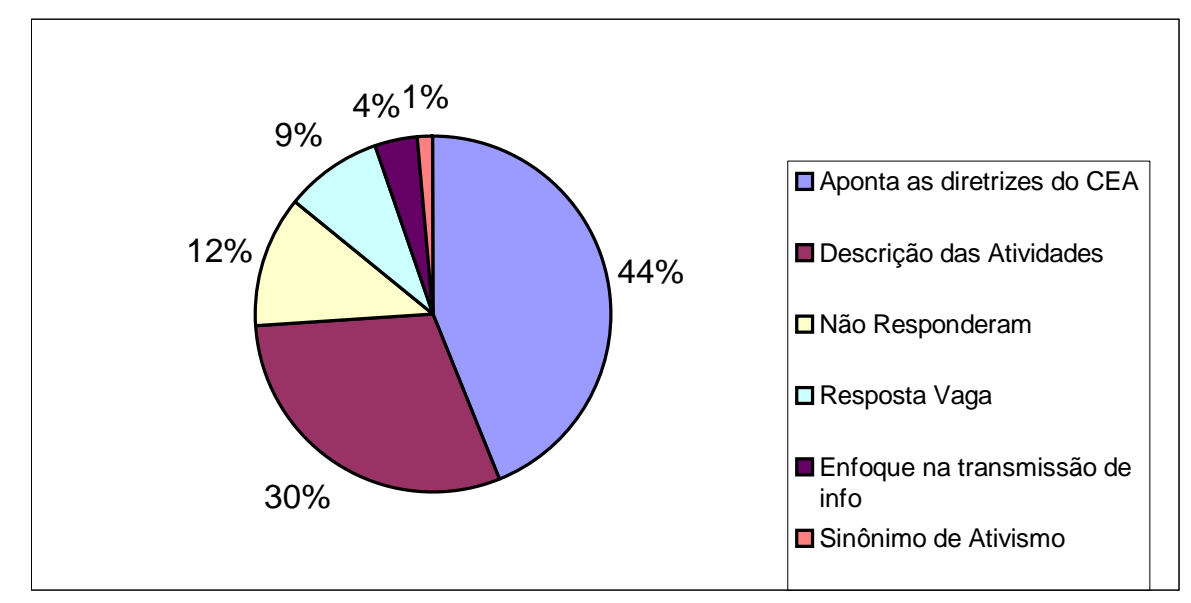

Figura 32 - Descrição do PPP em linhas gerais 
Dos $66 \%$ de CEAs que responderam possuir um Projeto Político-Pedagógico (Figura 30), visualizamos na Figura 32 que 44\% deles referem-se a ele apontando as diretrizes gerais do CEA, não entrando em mais detalhes. Em tais diretrizes vislumbramos princípios dos CEAs, como: interdisciplinariedade, cooperação, diálogo, dentre outros. Na seqüência verifica-se $30 \%$ dos CEAs que ao referir-se sobre seu PPP, descrevem algumas de suas principais atividades desenvolvidas. Por exemplo: "oferecemos trilhas interpretativas para possibilitar contato dos visitantes com o ambiente natural, seguidas de palestra e oficina". Ainda tivermos $12 \%$ de CEAs que não responderam à questão; $9 \%$ que deixou a resposta vaga, praticamente incompreensível; 4\% que consideram seu PPP como sendo sinônimo de transmissão de informações; e por fim 1\% que o trata como ativismo puro.

Partindo da compreensão de Projeto Político-Pedagógico que este estudo buscou dialogar, percebemos nos dados relativos a este item que há uma compreensão "apoucada" e, até mesmo, confusa do tema: ou é visto como uma coisa prática, reportando às atividades, que o CEA realiza; ou é visto como teoria, sobretudo quando os CEAs apontam para as diretrizes e os princípios que orientam sua ação. No entanto, em nenhum momento ele é entendido na sua totalidade, ou seja, como um Projeto que agregue tanto elementos teóricos (indo muito além de diretrizes e princípios) quanto práticos (descrição e detalhamento das atividades que realiza, etc) e que consegue promover sinergia e integração entre ambos.

Veremos a seguir quais as formas que os CEAs adotam para proceder a avaliações das atividades que oferecem e do CEA como um todo.

Visualiza-se na Figura 33 que há três estratégias com praticamente as mesmas porcentagens e totalizando 60\%: reuniões com a equipe (21\%); questionário (20\%); e observação direta (19\%). Os 40\% restantes estão divididos em cinco outras formas: reuniões com o público (13\%); livro de registros (11\%); entrevista (8\%), outras (5\%); e caderno de campo (3\%). 


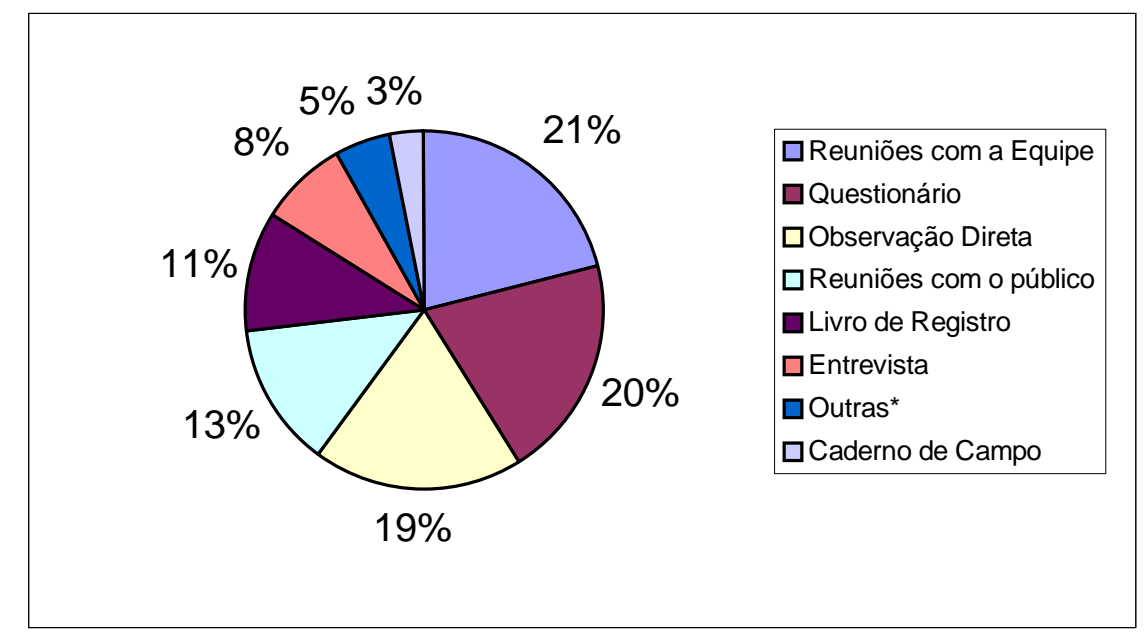

Figura 33 - Formas de avaliação das atividades dos CEAs

Percebe-se que das estratégias utilizadas, duas são implementadas pelos membros da equipe educativa do próprio CEA (reuniões com a equipe e observação direta, representando $39 \%$ dos casos), enquanto que todas as demais (61\%) são de responsabilidade dos públicos que freqüentam o CEA. Há, entretanto, uma considerável variedade de estratégias avaliativas empregadas nos CEAs estudados, que vão desde simples listagem estatística (número de visitantes/ano, como é o caso do uso de "livro de registros"); outras de cunho mais dialógico-reflexivo (como entrevistas, reuniões); outras com foco mais no registro de impressões (caderno de campo) e por fim estratégias bastante subjetivas (observação direta, que pode ou não ser seguida de algum instrumento de sistematização destas impressões).

Verifica-se na Figura 34 que, das estratégias mais freqüentemente empregadas para avaliação dos CEAs (48\%), tem-se como agentes responsáveis membros das equipes educativas do próprio CEA, como reuniões com a equipe (30\%) e observação direta (18\%). O uso de "questionário" é também bem freqüente (16\%); seguido por "reuniões com o público"; "entrevista"; e "livro de registro" (todos com 9\%). Uma minoria apontou para a adoção de "caderno de campo" e "outras" formas (4\%); e 1\% afirma que não adota nenhuma estratégia avaliativa. 


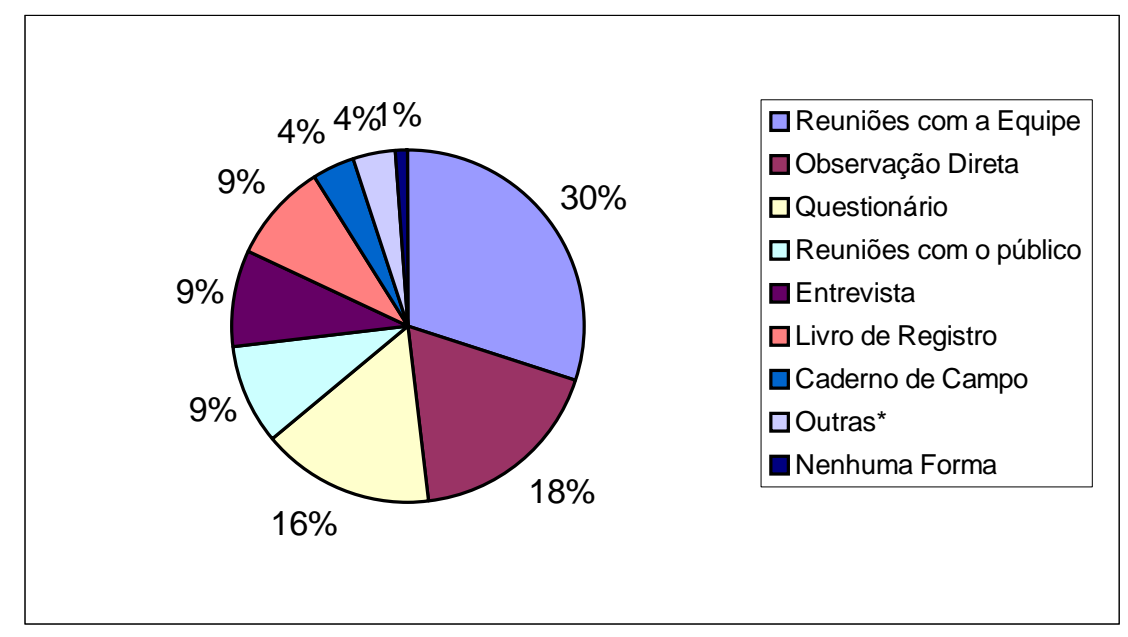

Figura 34 - Formas de avaliação do CEA

Cabe-nos tecer algumas considerações quanto aos dados apresentados. Em primeiro lugar é preciso que se discuta a marca de $48 \%$ relativa a uso de estratégias avaliativas como "reuniões com a equipe" e "observação direta". Como estas duas ocorrem na prática? Quais métodos utilizam-se para avaliar o CEA quando a estratégia é "reuniões com a equipe"? Há algum produto resultante deste processo? A estratégia "observação direta" pode ser considerada como sendo sinônimo de "observação participante"?

Entendemos que o delineamento e a implementação de um conjunto de estratégias avaliativas tanto das atividades que os CEAs desenvolvem, como do próprio CEA (em todos os seus aspectos) constitui-se importante dimensão a ser considerada junto aos Projetos Político-Pedagógicos de CEAs no Brasil. Este conjunto de estratégias deve enunciar quem são os agentes responsáveis pela avaliação; quando se implementam tais ações e como proceder. Levantamos aqui que quanto a definição dos agentes de avaliação é preciso que se perceba a necessidade de delinear e implementar processos avaliativos de duplo sentido: de caráter interno e externo. Ou seja, o CEA precisa além de auto-avaliar-se, de estar disposto a permitir que outros agentes o façam. Agentes como as próprias pessoas que freqüentam o CEA e participam das suas atividades (direta ou indiretamente) e instituições diversas (as quais podem cumprir ou não um papel regulatório). Contudo, mais do que explicitar 
os agentes, é preciso dizer quando e como eles atuam. O processo avaliativo é contínuo ou em determinados momentos/instâncias? Em quais deles? Como o processo será deflagrado? Como se avaliar o próprio processo de avaliação?

O conjunto destas questões direciona-nos para refletir sobre a necessidade ou não de um sistema de avaliação de CEAs o qual seria o responsável por exercer um papel de "controle de qualidade" junto a estas iniciativas no país. Caberia então a este sistema explicitar quais iniciativas podem ser consideradas, de fato, como sendo Centros de Educação Ambiental? Quais os critérios mínimos para ser considerado como tal? Como assegurar aos públicos que freqüentam estas iniciativas mínimos padrões de qualidade? Qualidade aqui entendida como um conjunto de elementos presentes no CEA que possibilitem que as pessoas que o freqüentam tenham suas expectativas iniciais superadas, que saiam do CEA satisfeitas. Até mesmo mais que satisfeitas, as pessoas deveriam ser provocadas pelos CEAs a perceber seu potencial de ação frente à realidade que as cercam.

Cabe ressaltar que estamos dialogando com uma concepção de CEA que pode até cumprir um papel de lazer, mas tem como um dos seus objetivos centrais a promoção de processos pedagógicos em educação ambiental. Disto não podemos abrir mão para que se visualizem as iniciativas de CEAs como CEAs. Portanto, os públicos com os quais o CEA trabalha serão mais ou menos "impactados" e "provocados" pelo CEA na medida em que se deflagrem processos pautados muito mais na pró-atividade. Entendemos que CEAs podem e devem cumprir um papel de emulador/estimulador/deflagrador de processos educacionais em EA sintonizados com uma perspectiva crítica, política (sem vinculação partidária) e sobretudo dialógica, em que as pessoas tenham condições de expressar-se, de contribuir para a construção do seu processo educacional no CEA.

Que o público não disponha apenas de acesso a informação, oportunidade de opinar/refletir sobre ela, mas sobretudo a possibilidade de que algo aconteça, por meio da experiência.

"A experiência, a possibilidade de que algo nos aconteça ou nos toque, requer um gesto de interrupção, um gesto que é quase impossível nos tempos que correm: requer parar para pensar, parar para olhar, parar para escutar, pensar mais devagar, olhar mais devagar, e escutar mais 
devagar; para para sentir, sentir mais devagar, demorar-se nos detalhes, suspender a opinião, suspender o juízo, suspender a vontade, suspender o automatismo da ação, cultivar a atenção e a delicadeza, abrir os olhos e os ouvidos, falar sobre o que nos acontece, aprender a lentidão, escutar aos outros, cultivar a arte do encontro, calar muito, ter paciência e dar-se tempo e espaço (Bondía, 2002, p.24).

Quanto às concepções que os CEAs analisados afirmam ter sobre o tema "Biodiversidade", identificou-se que, apesar de ser um tema bem trabalhado (citado por 77 dos 101 CEAs (Figura 29) e correspondendo a 76,2\% do total) ele é concebido de maneira ainda superficial, como podemos visualizar na figura seguinte.

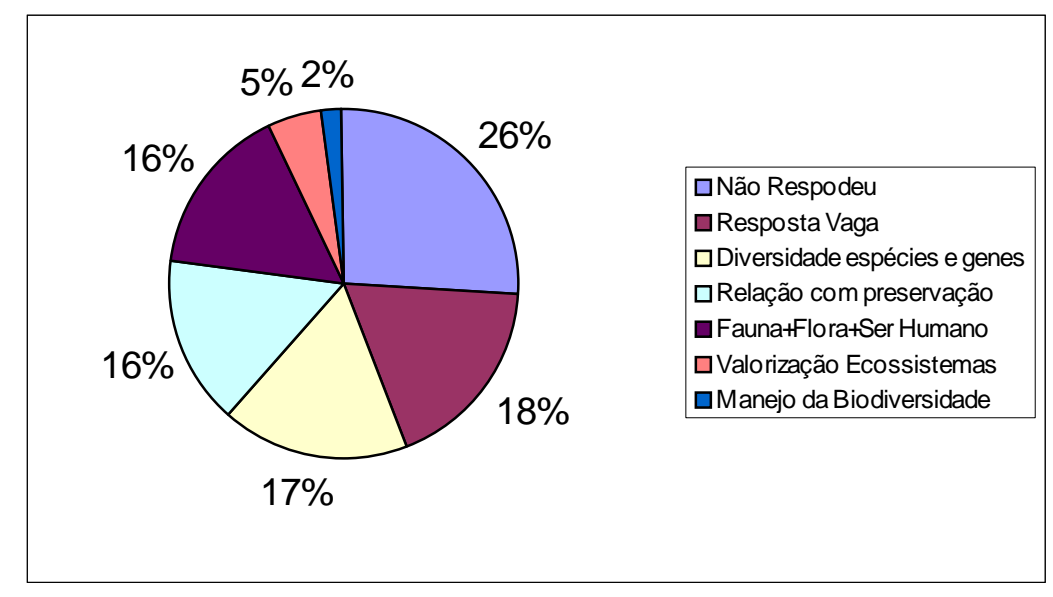

Figura 35 - Concepções sobre o tema "Biodiversidade"

Visualiza-se que $26 \%$ dos CEAs que afirmaram trabalhar com o tema não responderam à questão. Dos demais, observa-se que 18\% esboçou alguma resposta, porém vaga; $17 \%$ afirmam ter uma compreensão sobre "Biodiversidade" como sendo sinônimo de diversidade de espécies e de genes; 16\%, ao tratar do assunto, estabeleceu uma relação direta entre ele a necessidade de preservação enquanto que outros $16 \%$ o consideram como sendo o conjunto da fauna, da flora, com a inclusão do ser humano. Os demais (7\%) estabelecem relação entre o tema e a necessidade de valorização de ecossistemas (5\%) e a importância do manejo da biodiversidade (2\%). 
Percebe-se numa análise mais aprofundada dos dados expostos que há uma compreensão "apoucada" por parte dos CEAs quanto ao tema "biodiversidade". Compartilhamos da compreensão de Wilson (1997) sobre o tema, o qual considera que ela é o conjunto de espécies (animais, vegetais, microorganismos, algas), de ecossistemas e de diversidade genética de todos eles, e agregando a este conjunto os diversos elementos da cultura humana (inclusive as diferentes maneiras dos humanos perceberem a biodiversidade).

Com base nesta concepção de biodiversidade e observando atentamente para os dados apresentados pela Figura 34, visualizamos que uma minoria dos CEAs estudados declara sintonizar com uma concepção "expandida" do tema, que considera todos os elementos das ciências naturais, agregando também elementos da cultura humana, das relações que os diversos povos estabelecem com parte dos componentes dessa biodiversidade.

\section{G) Bloco 7 - Situação Atual e Perspectivas}

Neste bloco abordaremos tópicos relativos aos problemas atuais enfrentados pelos CEAs analisados e quais suas principais perspectivas para os próximos cinco anos.

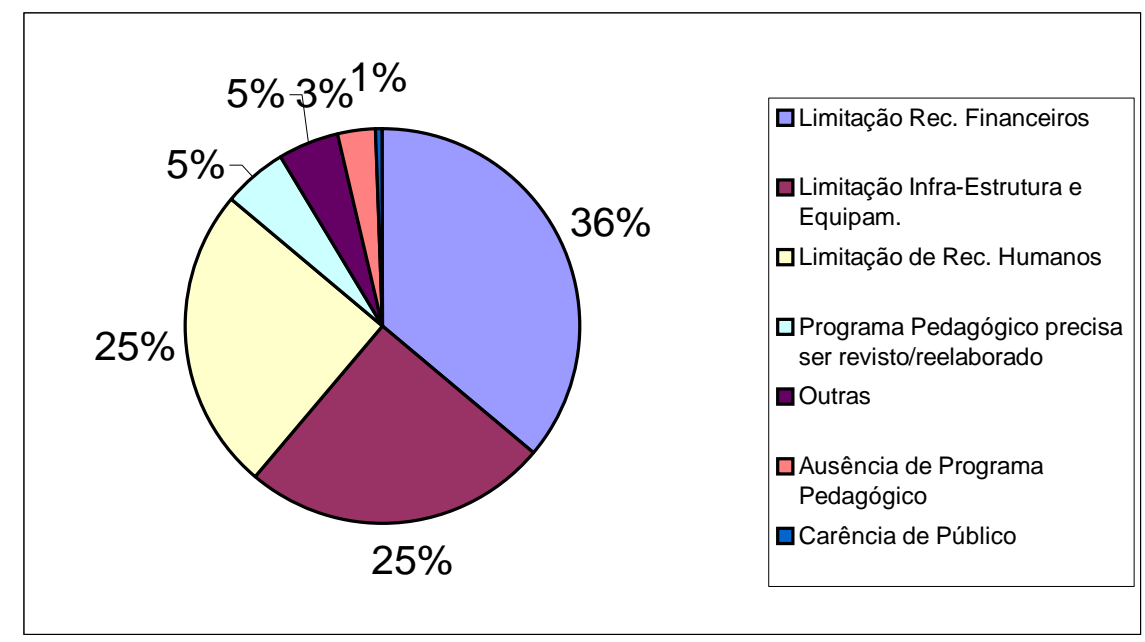

Figura 36 - Dificuldades enfrentadas pelos CEAs 
Nota-se na Figura 36 que há três principais dificuldades enfrentadas pela maioria dos CEAs estudados (86\%) na atualidade: a) limitação de recursos financeiros (36\%); b) limitação de infra-estrutura e de equipamentos (25\%); c) limitação de recursos humanos (25\%). Percebe-se que tais dificuldades concentram-se em questões materiais e humanas, ou seja, recursos (financeiros e não financeiros) e pessoas (equipe). As demais limitações apontadas (14\%) indicam a necessidade do programa pedagógico ser revisto/reelaborado (5\%); para diversas outras dificuldades (5\%); para a ausência de programa pedagógico (3\%) e para a carência de público (1\%).

Analisando inversamente os dados, verifica-se que o fator "público atendido" não se constitui problema na atualidade para a grande maioria dos CEAs analisados, o mesmo pode ser afirmado para a questão do Projeto Político-Pedagógico. Isto pode ocorrer porque essa dimensão é considerada pouco relevante para estes CEAs ou porque ela está bem equacionada no conjunto do CEA. Pelos dados apresentados e discutidos anteriormente, relativos a esta dimensão do PPP, caminhamos para considerar que a primeira hipótese é mais real. Se olharmos para o gráfico seguinte, que trata das perspectivas dos CEAs para os próximos cinco anos, essa hipótese também se corrobora.

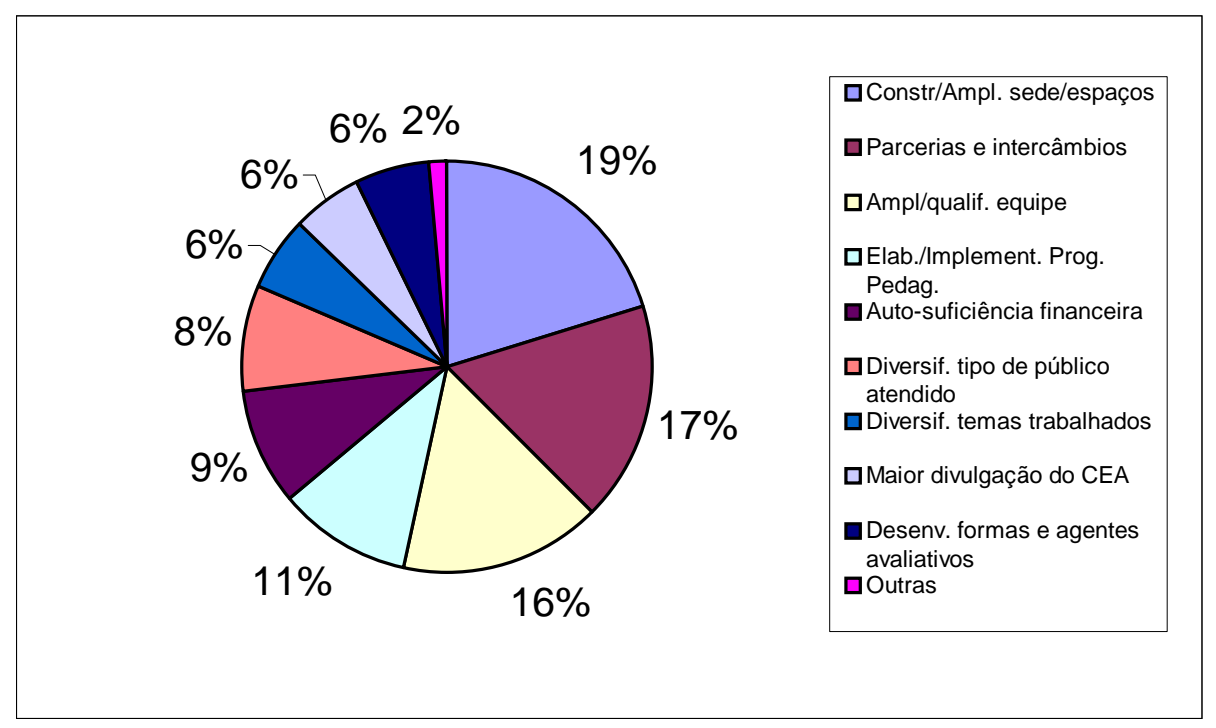

Figura 37 - Perspectivas dos CEAs para os próximos 5 anos 
Visualiza-se na Figura 37 que as três principais perspectivas para os próximos cinco anos para a maioria dos CEAs em questão (52\%) são: a) construção e/ou ampliação da sede e/ou de outros espaços (19\%); b) fomentar e estabelecer parcerias e intercâmbios (17\%); c) ampliação e qualificação da equipe educativa (16\%). As demais questões enunciadas (48\%) referem-se a: a) necessidade de elaboração e/ou implementação do Projeto Político Pedagógico (11\%); b) busca da auto-suficiência financeira (9\%); c) diversificação do público atendido (9\%); d) diversificação dos temas trabalhados (6\%); e) maior divulgação do CEA (6\%); f) desenvolvimento de formas e de agentes de avaliação (6\%); e g) outras questões.

Entendemos que a visualização de questões como as enunciadas neste bloco podem contribuir para orientar a formulação de políticas públicas, programas e projetos voltados à temática dos CEAs no Brasil. Identificar e entender as principais dificuldades enfrentadas pelos CEAs na atualidade bem como as perspectivas deles para os próximos anos possibilitam um maior entendimento conjuntural destas iniciativas na mesma medida em que ajudam a visualizar lacunas que merecem ser mais bem analisadas e discutidas.

\section{H) Bloco 8 - Espaço Livre}

Neste bloco concentramos considerações acerca da avaliação dos questionários utilizados como instrumento de coleta de informações deste estudo bem como comentários livres que os CEAs teceram.

Quanto aos espaços livres existentes para comentários que se julgassem necessários verificou-se que a maioria dos CEAs analisados optou por deixá-los em branco (50\% no questionário 1; e $82 \%$ no questionário 2). Os demais, ou aproveitaram os espaços para trazer mais informações sobre suas atividades (26\% e 16\% nos questionários 1 e 2, respectivamente). No questionário 1, verificou-se também um percentual (15\%) que menciona sobre a origem do CEA seguido de uma minoria (6\%) que ressalta a necessidade de ter algum retorno com este estudo.

Quanto à avaliação dos questionários, observou-se que ambos foram bem aceitos de uma forma geral, recebendo algumas sugestões e críticas, como veremos nos gráficos seguintes. 


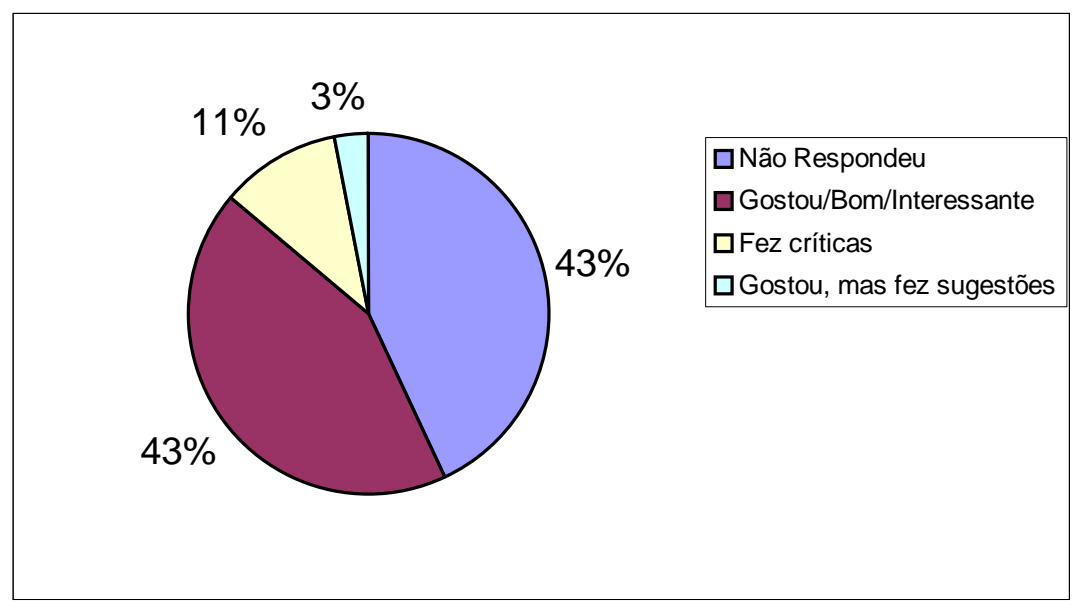

Figura 38 - Avaliação do Questionário 1

A visualização da Figura 38 permite perceber que 43\% dos CEAs da amostra não respondeu à questão, ou seja, não avaliou o questionário 1 . Outros $43 \%$ o consideram como bom, interessante, enquanto que 11\% teceram críticas a ele, tais como: consideraram-no muito genérico e abrangente; tiveram dificuldade no entendimento de algumas questões; e consideraram que havia pouco espaço em geral para responder às questões.

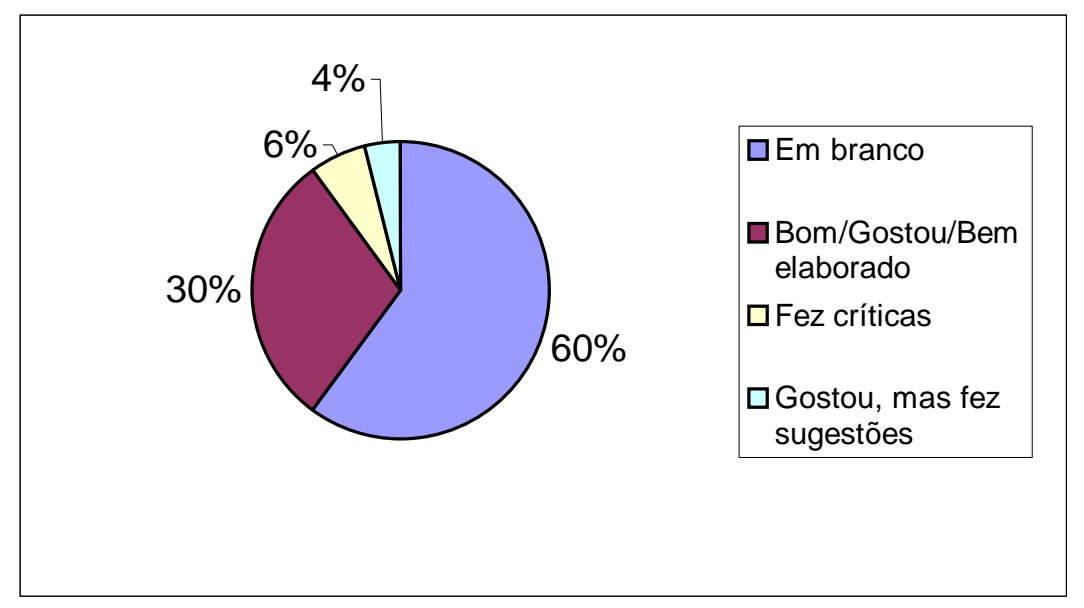

Figura 39 - Avaliação do Questionário 2 
$\mathrm{Na}$ Figura 39, relativo a avaliação do questionário 2, percebe-se que 0 percentual de CEAs que não respondeu à questão é maior que no questionário anterior, ampliando sde $43 \%$ para $60 \%$. Dos $40 \%$ restante verifica-se que $30 \%$ gostou do questionário 2 , considerando-o bom e interessante, enquanto que $6 \%$ teceu críticas, como: longo, sem instrução para preenchimento, sem prazo para retorno, confuso e muito fechado.

Para uma próxima pesquisa semelhante a esta, considera-se mais pertinente a existência de um único campo para avaliação, o que possibilita que um maior percentual de CEAs responda a questão. Com relação às outras críticas recebidas é possível discuti-las rapidamente.

De fato, ambos questionários eram bastante longos porque se pretendia realizar um levantamento de uma gama de informações que pudessem conduzir a um trabalho de diagnóstico destas iniciativas no país. Quanto a presença de instruções para o preenchimento, estas estavam postas na carta de apresentação que seguia cada kit enviado aos CEAs. É provável que em alguns casos, ela possa ter se separado dos questionários, o que acabou gerando alguma dificuldade no momento de seu preenchimento. Em relação a não explicitação de prazos para retorno, isso foi propositadamente assumido, como uma estratégia que pudesse servir de estímulo a que mais CEAs contribuíssem com a pesquisa. Entendemos que a adoção desta estratégia foi mais interessante do que se tivéssemos delimitado prazos, mas merece ser analisada de acordo com o tipo de pesquisa que se pretende realizar, bem como com os prazos que se tem para realizá-la. Quanto ao caráter "fechado", também constituiu-se numa estratégia definida para facilitar posterior tabulação. A presença de muitas questões "abertas" pode ser mais interessante porque permite a visualização de informações qualificadas, contudo pode tornar o questionário mais complicado pra tabulação, sistematização e análise. 


\section{CONCLUSÕES}

Retomamos as três questões iniciais com as quais este trabalho estabeleceu continuado diálogo e reflexão, e que buscavam abordar, ao menos quatro dimensões da temática:

1) Teórico-conceitual: "Afinal, o que são CEAs? O que fazem? Qual sua finalidade? Quais seriam os elementos mínimos para uma iniciativa ser considerada como sendo um CEA? Qual sua situação atual? Como estão distribuídos no país?"

2) Histórica: "Há convergência entre os marcos/fatos históricos do movimento ambientalista e da Educação Ambiental e os de criação dos Centros de Educação Ambiental no Brasil?"

3) Tipológica: "É possível criar classificações tipológicas de CEAs brasileiros a partir da adoção de princípios da EA e do movimento ambientalista?"

4) Situacional: "Qual a situação atual da temática? Como os CEAs estão distribuídos no país?"

Com base nestes eixos e visualizando as questões que orientaram este trabalho podemos considerar que as mesmas puderam ser respondidas, ao menos parcialmente. Através do levantamento e do mapeamento de iniciativas de CEAs pelo país, processo este que resultou em 101 CEAs compondo a amostra, foi possível a sistematização de diversas informações e de muitos dados relativos à temática. Dados estes que nos permitiram discutir com um conjunto de referenciais teóricos relativos à literatura brasileira sobre CEAs, sobre EA, sobre ambientalismo, e construir propostas conceituais, tipológicas, históricas e situacionais sobre a temática.

Retomando, também, o conjunto de hipóteses iniciais percebemos que, de fato, há considerável diversidade de "tipos" e concepções de CEAs no país, configurando um cenário variado de iniciativas e propostas. O conjunto de informações e de dados levantados apontaram, no entanto, que há considerável predominância de 
uma das oito classes de CEAs propostas, chegando a representar $40 \%$ do total da amostra. Embora haja significativa variedade de "tipos" de CEAs, há, também, considerável desigualdade na distribuição de iniciativas pelas oito classes propostas.

E este "tipo" de CEA predominante no Brasil refere-se justamente àquela classe que tem como foco de atuação a questão da interpretação da natureza, que é implementada por meio de atividades de poucas horas de duração, em geral trilhas guiadas majoritariamente voltadas ao público escolar. Verificou-se que, em geral, esta classe de CEA parte de uma abordagem de intervenção no campo da EA com um parcial escopo político e popular, mais voltada a uma linha comportamentalista/prescritiva da EA. Esta constatação faz emergir uma discussão, que certamente poderá ser alvo de estudos e trabalhos posteriores, relativa ao Estado da Arte da EA que é pensada e praticada no Brasil na atualidade, nas suas diversas organizações, movimentos, redes, fóruns, comissões, comitês, indivíduos, CEAs, etc.

Quanto à segunda hipótese deste trabalho, relativa ao avanço na compreensão do papel dos CEAs na construção de sociedades sustentáveis a partir da reflexão de pressupostos e princípios básicos da EA e do ambientalismo - no caso a fundamentação teórica buscou subsídios e elementos nos conceitos da participação e do diálogo - verificou-se, ainda que de maneira preliminar, são conceitos compreendidos com certa superficialidade pela grande maioria dos CEAs estudados e tratado de forma bem divergente entre eles. Se há uma concepção geral sobre eles, ela é pautada muito mais enquanto retórica do que enquanto possibilidade real de sua implementação prática. Reforçamos isso porque, embora este trabalho não tenha realizado o acompanhamento, o monitoramento e o aprofundamento dos dados no campo, ele conseguiu levantar suficiente repertório de informações e de dados que possibilitaram a construção de algumas considerações mais sólidas. Os CEAs brasileiros, em geral, tendem a aprimorar muito mais seu discurso no tocante a processos de participação dialógica do que sinalizar para sua implementação na prática. Enquanto refinam seu discurso conceitual, acabam deixando descoberto todo o campo metodológico e estrutural que viabiliza tais processos de forma efetiva. Falam de participação sem, no entanto, atentarem para a oferta de atividades que estimulem, facilitem e provoquem processos educacionais com este espírito. Vimos quais são os principais tipos de intervenções que praticam; quais as concepções que têm quanto a Projetos Político-Pedagógicos; como implementam suas estratégias de avaliação, dentre outras constatações. 
De fato, estudos que permitam vizualizar com mais profundidade o testemunho de tais conceitos (e de outros) são bem vindos, necessários e importantes. Este estudo não permitiu um aprofundamento teórico muito focado na questão do diálogo que os CEAs estabelecem com princípios e conceitos do ambientalismo e da EA brasileira. Tratam-se de estudos relevantes para adensarmos conceitualmente a temática dos CEAs, agregando a ela reflexões e considerações que consigam absorver pressupostos mais diversificados, contribuindo para uma real epistemologia dos CEAs brasileiros.

Contribuições com estas possibilitarão melhor visualização de convergências entre o papel dos CEAs na construção de sociedades sustentáveis, sobretudo, dialogando com diversificados pressupostos do ambientalismo e variáveis fundamentos da educação ambiental.

Consideramos serem estas questões de extrema relevância para o campo da EA nacional e internacional, uma vez que se trata de um conjunto consideravelmente diversificado de práticas, experiências e saberes, que tendem a intervenções com vinculações sociais, políticas (não partidárias) e culturais muito fortes.

Um conhecimento mais aprofundado de princípios e de conceitos da EA e do ambientalismo permitirá a construção do processo de tipologização de CEAs com mais segurança, com propostas menos passíveis de equívocos e incoerências. As propostas tipológicas apresentadas neste trabalho foram formuladas a partir de importantes subsídios de publicações e experiências da Espanha, os quais se mostraram suficientes para a apresentação de propostas de classificação tipológicas iniciais para Centros de Educação Ambiental brasileiros. Na medida em que se avance na reflexão e produção teórica sobre a temática; numa divulgação mais ampla da existência dos CEAs, de suas múltiplas facetas e de suas ações e realizações; no avanço da Rede CEAs, de outras rede correlatas e da participação de CEAs em outras redes; dentre muitas outras ações possíveis; encontraremos ambiente mais fértil do que o atual para proposições de classificações tipológicas de CEAs brasileiros, com mais acúmulo e menos risco de distorções com a realidade.

\section{Retornando aos objetivos propostos, visualiza-se que foi possível:}

1) O entendimento dos fatos e movimentos que deram origem à formação dos primeiros CEAs no país, e seus antecedentes. 
Verificou-se que o processo de surgimento dos CEAs considerados "pioneiros" no país teve início em meados dos anos 70, coincidindo, portanto, com o despertar do movimento ambientalista brasileiro (de acordo com o que propõem alguns autores desta área). Observou-se que o poder público foi o protagonista mais importante no impulso e fomento aos CEAs, considerando as fases iniciais deste movimento (primeira e segunda fases, compreendendo o período de 1976 a 1992) e a partir do início da terceira e da quarta fases (atual) - relativas ao período 1993 - 2003 foi saindo de cena, e este vácuo foi preenchido por instituições do setor privado, do chamado terceiro setor e de parcerias entre estes (caráter misto).

O estudo e reflexão deste objetivo do trabalho também possibilitou visualizar que os diversos "tipos" propostos de CEAs vão emergindo em fases históricas distintas. Na fase inicial de surgimento dos CEAs no Brasil (1976-1987) verificou-se a emergência iniciativas mais ligadas a tendências conservacionistas da Educação Ambiental, tendo como exemplo, propostas de CEAs localizados em Unidades de Conservação, museus e zoológicos. Nesta fase a finalidade central destes CEAs era a interpretação da natureza. Já a partir do final desta fase observou-se que há um processo de ruralização dos CEAs, que passam a focar sua ação nas questões agroecológicas e de agricultura orgânica, certamente como uma resposta às conseqüências e desdobramentos do processo de revolução verde, ocorrido no setor agropecuário brasileiro a partir do início dos anos 70.

A partir do final dos anos 80 e, com mais ênfase, a partir do período pós Eco-92 este movimento de CEAs amplia-se consideravelmente no país, em termos de envolvimento de setores e organizações da sociedade. Foram lançados aí os chamados projetos pilotos de CEAs, ligados ao MEC, que não alcançaram grande êxito.

Todo este movimento de CEAs no país, apesar de toda expansão e diversificação, ficou marcadamente restrito à região centro-sul do país, com especial destaque para as regiões sudeste e sul. Coincidentemente são aquelas onde o movimento ambientalista emergiu e batalhou conquistas no seu processo histórico de emergência, como também são aquelas onde o processo desenvolvimentista brasileiro ocorreu (e ocorre) com mais vigor e pujança.

2) A seleção de indicadores (critérios) que permitiram a construção de classificações tipológicas dos diferentes tipos de CEAs existentes no país; 
Como visto, uma relação de critérios foi obtida a partir da revisão de literatura espanhola especializada no assunto, que demonstraram ser passíveis de aplicação no Brasil, sendo portanto, aqueles mais recorrentes: Tipo de Atividades; Público Atendido; Infra-estrutura; Localização do CEA; e Instituições Promotoras e Gestoras.

Observou-se que há certo acúmulo na literatura da EA brasileira quanto a propostas de classificação tipológica das tendências da EA. No entanto verificou-se o contrário no que diz respeito a temática dos CEAs.

Certamente novos estudos poderão avançar no campo das classificações tipológicas para CEAs brasileiros, que permitirão conhecer mais amplamente e mais profundamente este movimento e cada uma destas iniciativas: o que são, o que fazem, pra quê e pra quem servem, etc. É preciso, porém, que eles reflitam sobre a dificuldade de se construir propostas de classificações tipológicas sem perder de vista a possibilidade de distorções e inadequações práticas, uma vez que a temática é complexa e dificulta categorizações isentas de incoerências. Elas, por sua vez, esforçam-se por esboçar um panorama da diversidade de classes, tipos, vocações que CEAs brasileiros apresentam, e contribuem para clarificar uma compreensão expandida desta temática.

Este estudo trabalhou dois processo de tipologização para CEAs brasileiros, sendo um denominado simples e o outro complexo. O primeiro adotou como critério um único item, no caso, a instituição promotora e gestora do CEA, e propôs nove classes distintas: empresas públicas; órgãos governamentais federais; órgãos governamentais estaduais; órgãos governamentais municipais; fundações; universidades; empresas privadas; ONGs; e outras instituições (agências de cooperação, consórcios, etc). O segundo processo de tipologização adotou aqueles critérios apontados anteriormente acrescidos por mais alguns - características do entorno; objetivos/missão do CEA; projeto político pedagógico - e avançou na proposição de uma classificação com oito categorias de CEAs. Cada uma delas foi organizada tendo como eixo orientador a finalidade principal destes CEAs, compreendendo:
a) disponibilização de informações;
b) sensibilização, reflexão e revisão de valores;
c) formação;
d) interpretação;
e) delineamento e implementação de projetos, consultorias, eventos;
f) articulação para potencialização de ações; 
g) lazer, ócio e atividades lúdico-culturais;

h) desenvolvimento de projetos de pesquisa.

3) A composição de um banco de dados dos CEAs relativos a cada classe tipológica, com o intuito de disponibilizar informações principais a respeito de cada CEA estudado. Este se encontra disponível no site da Rede CEAs, e em discussão quanto à sua migração ou compartilhamento com o banco de dados do SIBEA;

Como afirmamos neste trabalho, percebemos no decorrer do estudo que a construção de um banco de dados não era seu objetivo central, mas sim instrumento essencial não só para subsidiar seus demais objetivos, como também por constituir-se em importante estímulo à emergência da Rede CEAs e, conseqüentemente, como um dinamizador do movimento de CEAs no país. Sobre esta idéia - de movimento de CEAs no país - conseguiu-se apenas levantar este questionamento; propor esta reflexão. No entanto, não houve condição efetiva de realizar-se uma análise mais ampla no que diz respeito à sua caracterização; delimitação das suas especificidades; interação com outros movimentos, etc.

Obviamente o avanço em processos de disseminação e divulgação de informações sobre a temática dos CEAs e sobre eles, contribuirão para que novos estudos e experiências sejam realizadas; para que este movimento possa alimentar-se destas informações e ser retroalimentado por elas; assim como para que políticas públicas possam ser formuladas para avançar na popularização e enraizamento destas iniciativas nas distintas regiões e ligadas aos mais diversos setores e organizações do país

Com o avanço da internet, e das inúmeras possibilidades decorrentes dela, a dimensão da disponibilização de informações sobre CEAs ganha mais corpo e materialidade. Simultaneamente ao seu desenvolvimento e consolidação, emerge a necessidade de que um processo de popularização desta ferramenta seja deflagrado; de que a questão da inclusão digital seja amplamente discutida, formulada e trabalhada junto aos diversos segmentos da sociedade brasileira. Há diversos programas, projetos e ações em curso que certamente contribuem para popularizar a internet no país e, de acordo com os dados levantados por este estudo, pode-se concluir que a grande maioria dos CEAs analisados estão incluídos digitalmente, ou seja, dispõe de um correio-eletrônico para contato. 
4) Demonstraram-se importantes a análise e a discussão de questões relativas à temática, dentre elas: como compreendem e como trabalham a questão da biodiversidade, quais concepções e objetivos conferem às suas iniciativas; quais as formas de avaliação mais empregadas e quem realiza essa tarefa; e quais as concepções vigentes de um projeto político pedagógico de CEAs.

Verificou-se que, de forma geral, os CEAs estudados partem de uma concepção simplificada destes conceitos - biodiversidade; avaliação e projeto político pedagógico, conferindo-Ihes uma abordagem reducionista quanto às suas dimensões. Especialmente com relação a questão do Projeto Político-Pedagógico. Observou-se também que quase um terço destes CEAs sequer dispõe de um PPP - elemento este que consideramos essencial em qualquer iniciativa que se proponha a ser um Centro de Educação Ambiental.

Esta questão parece-nos ser a mais importante e urgente a ser discutida, refletida e estudada com mais profundidade no país. A despeito de existirem diversas iniciativas que se consideram como "CEAs" sendo projetadas e implantadas no Brasil sem qualquer discussão e reflexão acerca da construção de um Projeto PolíticoPedagógico, esta dimensão deve ser encarada como sendo algo central, essencial e indispensável. Ela diz respeito ao conjunto das orientações/sustentações ideológica, conceitual, material, política, prático-metodológica, econômica e espiritual do Centro de Educação Ambiental. Refere-se, ainda, a produtos e a processos, requer uma práxis permanente, pautada em pressupostos e princípios como a participação dialógica abordados neste estudo, como muitos outros. Conceitos que consideramos essenciais na questão do PPP para CEAs merecem reflexões mais aprofundadas em virtude de uma apropriação do discurso verificada com certa facilidade no campo da EA .

Embora tenhamos verificado que a maioria dos CEAs afirmaram dispor de um PPP, é preciso que se amplie a reflexão e a discussão a respeito das concepções e compreensões que estes CEAs têm efetivamente sobre a questão e como isso se materializa na sua práxis cotidiana, na sua interação com os públicos (pessoas e organizações) com os quais dialoga e se relaciona.

Entendendo que a questão das formas de avaliação mais empregadas e os agentes que as realizam é detalhamento da dimensão do PPP, verificou-se que há certa diversidade de opções mais claras nas formas de avaliação das ações do CEA e dele próprio do que nos agentes responsáveis por isso. 
Embora concluamos que este trabalho conseguiu apresentar respostas convincentes às questões centrais de onde partiu, há algumas lacunas e reflexões pouco exploradas, por diversos fatores. A proposta inicial de construção de classificações tipológicas dos CEAs, seguida de um trabalho de campo que possibilitasse o cruzamento das informações, dos dados e de "olhares" e "leituras" práticos da temática, não pôde ser implementada. Constitui-se numa proposta pertinente, uma vez que concede "vida" aos dados levantados por meio de questionários, qualifica discussões e reflexões, desde que seja precedida de um processo de planejamento muito bem delineado. Trabalhos de campo como estes necessitam ser previamente desenhados, com instrumentos, procedimentos, prazos e pontos focais claros e factíveis. Como proceder a um levantamento teórico-prático de CEAs no Brasil, em tão pouco tempo? Talvez a resposta esteja na capacidade de formular problemas e hipóteses iniciais menos ousadas e mais realistas para o estudo.

Este trabalho pode ter contribuído para a temática dos CEAs brasileiros por diversos motivos. Um deles, por permitir visualizar que a situação dos CEAs no Brasil é ainda preliminar do ponto de vista teórico-conceitual. Enquanto observamos países como a Espanha discutindo e propondo critérios mínimos de qualidades que possam regulamentar os CEAs que lá atuam, no Brasil encontramo-nos num momento de luta por requisitos básicos que permitam afirmar que das diversas (e até hoje incontáveis e não mapeadas) iniciativas em atividade na atualidade, uma parte delas possa ser considerada como sendo CEAs.

No Brasil não se pode propor uma pauta com questões como "critérios de qualidade em CEAs" porque, de fato, há assuntos anteriores e fundantes no tocante à temática que precisam ser discutidos. Como propor tais critérios, se mal conhecemos quantas e como são as iniciativas atuantes no país, se mal sabemos onde e como elas estão?

Embora esta questão não possa ser considerada como pauta principal, ela pode ser entendida como um horizonte orientador para reflexões futuras e, porque não, atuais. Falar então de qualidade de CEAs no Brasil, na atualidade, é apontar para a necessidade de espaços e equipamentos que desempenhem um papel educacional de provocação de discussões, de reflexões, de construção do conhecimento, de facilitador de processos participativos e de constituição de recursos/instrumentos coerentes com princípios e conceitos fundantes do ambientalismo e da EA brasileira. 
Continuar falando desta qualidade implica na presença de uma equipe junto a estes CEAs, composta por profissionais em quantidade e qualidade suficiente para o desenvolvimento e implementação do seu Projeto Político-Pedagógico, dotados de habilidades e de experiências no campo da EA, sintonizados e comprometidos com o ideário ambientalista. Pressupõe testemunho cotidiano de uma práxis pedagógica transformadora, crítica, política e dialógica, pautada no respeito às diferenças, na inclusão na diversidade, dentre outros princípios.

Faz-se necessário que os CEAs não somente percebam a importância do PPP, mas que o incorporem de fato na sua práxis cotidiana como sendo sua grande "espinha dorsal", orientado e orientando um conjunto de estratégias avaliativas. Que inter-relacionem seu PPP com uma estratégia de sustentabilidade, entendida numa compreensão expandida que engloba todas as suas possíveis dimensões (sociais, culturais, políticas, ambientais, econômicas, etc) e permita que se construa um caminhar cotidiano sólido e menos suscetível a interrupções de continuidade.

Como visto, encontramos um conjunto de questões e dimensões que merecem ser urgentemente discutidas no que diz respeito à temática dos CEAs no Brasil. Dentre elas: a baixa diversidade de atividades desenvolvidas pelos CEAs estudados e de públicos atendidos; as concepções restritas do que viria a ser um PPP, com abordagens teóricas e metodológicas pouco inovadoras; estratégias avaliativas para o CEA e das atividades que ele empreende limitadas; plano de sustentabilidade para o CEA praticamente inexistente. Há ainda tópicos relacionados aos espaços, equipamentos e recursos que o CEA dispõe, os quais em geral exploram pouco seu potencial pedagógico; adoção de materiais mais ecológicos, menos impactantes nos edifícios; carência de fontes alternativas de energia e de outras tecnologias de arquitetura mais sustentáveis.

Por outro lado, vislumbramos que CEAs constituem, de fato, iniciativas com um fabuloso potencial de ação, porque dispõem de uma estrutura, mesmo que mínima, que serve de suporte e de locus para a criação e para o desenvolvimento de processos educacionais voltados à questão ambiental. Entendemos que os CEAs, de um modo geral, são um dos recursos mais completos, complexos, singulares e plurais, capazes de delinear, implementar e avaliar processos educacionais, apoiados por um conjunto de instalações próprias e/ou de terceiros, e rodeados por um entorno repleto de possibilidades pedagógicas. Nada mais facilitador para provocar tais processos, oportunizar o estabelecimento de parcerias e constituir-se como referência em EA de 
uma localidade, território, povoado, município, bairro, organização, etc. Além disso, CEAs podem ser concebidos como sendo iniciativas móveis, que podem atuar em diversos espaços, localidades e situações, se deslocar por diversos meios, se relacionando com vários tipos de públicos. Este então parece ser um elemento essencial na discussão relativa à temática dos CEAs - a criatividade deve ser este ingrediente, e parece mesmo ser um dos principais responsáveis pela concepção, desenho e implementação destas iniciativas pelo Brasil.

Este estudo também possibilitou a visualização de uma característica importante no tocante à presença de recursos tecnológicos em CEAs. A maior parte deles dispõe de computador, sendo que a maioria dispõe de correio-eletrônico, o que permite inferir que têm, portanto, acesso à internet. Isto pode significar uma considerável ampliação do potencial de atuação destes CEAs. Possibilita a criação e a produção de materiais diversos; conexão com outras pessoas e a redes; acesso a informações variadas e à tecnologias de educação à distância, dentre muitas outras alternativas advindas não só com o advento e expansão da internet, mas também de ferramentas técnicas e operacionais que o computador e seus acessórios dispõem.

Outra potencialidade observada com relação à temática dos CEAs diz respeito à diversidade de formações dos membros das equipes dos CEAs estudados. Há um leque de profissionais de distintas áreas de formação (humanas, biológicas, ciências da terra, exatas), o que possibilita repertório, olhares e abordagens mais diversificados, mais potencialmente sintonizados com uma leitura transdisciplinar das realidades (locais/globais).

Há, enfim, a partir das questões elucidadas e evidenciadas neste trabalho indícios de que a visualização dos CEAs como um movimento que guarda em si identidade própria e que merece ser encarado como tal, deve ser, no mínimo, considerada e debatida. De fato, tais indícios apontam para perspectivas interessantes quanto a novos estudos e reflexões acerca da temática deste trabalho e evidenciam elementos iniciais de um movimento que precisa ser visualizado, entendido, pesquisado e discutido com mais profundidade e de posse de mais subsídios.

A constatação de que se trata de uma temática mais complexa e plural do que tem sido abordada no país e com mais especificidades do que se poderia imaginar, faz com que a necessidade de formulação e implementação de políticas públicas específicas para esta área ganhem mais relevância e argumentos neste momento. Certamente há uma conjuntura favorável a esta percepção, a qual nos permite 
vislumbrar uma infinidade de caminhos a serem trilhados com relação à temática dos CEAs no país, que passam não só pela questão da ampliação, disseminação e divulgação destas iniciativas, mas, sobretudo, pela qualificação e reorganização das distintas demandas das diversas regiões e realidades brasileiras, nas múltiplas concepções e práticas das Educações Ambientais e de Centros de Educação Ambiental existentes num país como o Brasil. 
ANEXOS 


\section{ANEXO A - Kit enviado aos CEAs}

\section{Prezados Senhores,}

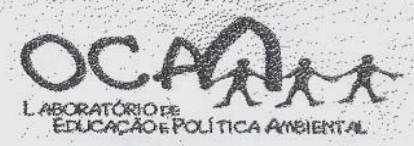

Piracicaba, 02 de Setembro de 2002.

Encaminhamos esses dois questionários com o intuito de coletar informações sobre Centros de Educação Ambiental (CEAs) em todo o país, como parte do projeto de mestrado do pesquisador Fábio Deboni da Silva, intitulado "Histórico, Classificação e Análise de CEAs no Brasil". Gostaríamos de solicitar vossa colaboração no sentido do devido preenchimento destes, bem como seu envio ao endereço localizado no rodapé desta carta (A/C: PROJETO CEAs), contribuindo assim para um estudo mais aprofundado da temática dos CEAs no Brasil. Ressaltamos que parte das informações serão posteriormente disponibilizadas em um banco de dados na internet, tornando-se acessíveis às vossas instituições e como um retorno a vossa contribuição à pesquisa.

Solicitamos que o preenchimento somente seja realizado se vossa instituição dispuser de Centro(s) de Educação Ambiental (CEAs). Entendemos como tal aquelas experiências no campo da Educação Ambiental não-formal, dotadas de: sede, infra-estruturas, recursos materiais e equipe pedagógica apropriados para o desenvolvimento de atividades de E.A. junto a distintos públicos. Se, por acaso, vossa instituição não se encaixa nesse perfil, e caso não conheça iniciativa semelhante na sua região, solicitamos que nos remeta tais questionários em branco, de modo a serem considerados em nossa posterior análise estatística.

Agradecemos vossa compreensão e disposição em ajudar-nos nessa importante tarefa de ampliar o conhecimento relativo aos CEAs no Brasil. Trata-se de um campo em considerável expansão na atualidade, e que carece de estudos no âmbito acadêmico. Entendemos que a universidade pública pode e deve contribuir para a discussão e divulgação de tais experiências, e consideramos a OCA - Laboratório de Educação e Política Ambiental, como um espaço público que pode colaborar no cumprimento de tais expectativas.

Depositamos assim plena confiança em vossa ajuda e encontramo-nos a disposição para maiores esclarecimentos, dúvidas, críticas e sugestões.

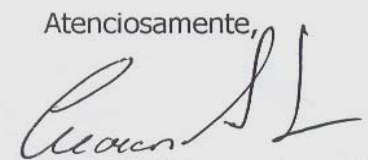

Prof. Dr. Marcos Sorrentino

Coordenador da OCA

$$
\text { faboblebridasiua }
$$

Fábio Deboni da Silva

Pesquisador OCA - Projeto CEAs

\section{fdsilva@esalq.usp.br}


Universidade de São Paulo - Escola Superior de Agricultura "Luiz de Queiroz" Programa de Pós Graduação em Recursos Florestais

Histórico, Classificação e Análise de Centros de Educação Ambiental (CEAs) no Brasil

Questionário 1

1) Dados do CEA:

1.1 - Nome do CEA:

1.2 -Ano de Início das Atividades:

1.3 - Endereço do EA:

1.4 - Endereço para correspondência:

1.5 - E-mail/ Home-age:

1.6 - Telefone/Fax:

1.7 - Localização:

$\square$ Área Urbana $\square$ Área Rural $\square$ Unidade de Conservação

Outra Qual:

1.8 - Dados do Gestor:

Nome da Instituição:

Endereço:

1.9 - Caráter da Gestão:

Pública $\quad \square$ Privada $\quad \square$ Mista

1.10 - Promotor do CEA: (marque quantos forem necessários)

$\square$ Prefeitura $\square$ ONG $\square$ Gov. Estadual $\square$ Empresa Privada

$\square$ Fundação $\square$ Empresa Pública $\square$ Gov. Federal $\square$ Universidade

$\square$ Outros:

1.11 - Dados do Promotor:

Nome da Instituição:

Endereço:

1.12 - Procedência da Verba que mantêm o CEA:

$\square$ 100\% Pública $\quad \square$ 100\% Privada $\square$ Mista 
1.13 - Horário de Funcionamento:

$\square$ Até 16 h./semanais $\square$ de 17 a 20 h./semanais

$\square$ de 21 a 40 h./semanais $\square+$ de 40 h./semanais

1.14 - Funciona aos Finais de Semana?

$\square \operatorname{Sim} \square$ Não

1.15 - Funciona em quais meses do ano:

$\square$ todos $\square$ julho, dezembro, janeiro e fevereiro

$\square$ outros:

2) Edifício, Infra-estruturas e Recursos:

2.1 - O edifício (sede) do CEA é uma construção:

$\neg$ Nova

$\square$ Adaptada (sem a necessidade de obras novas)

$\square$ Adaptada (com a necessidade de obras novas - ampliação)

$\square$ Não tem sede

2.2 - Listar os espaços e apêndices disponíveis para o CEA:

$\begin{array}{lll}\square \text { Biblioteca } & \square \text { Anfiteatro } & \square \text { Quiosques } \\ \square \text { Escritório } & \square \text { Laboratórios } & \square \text { Alojamento } \\ \square \text { Sala de Exposições } & \square \text { Armazém/Depósito } & \square \text { Sala de Reuniões } \\ \square \text { Sala de Oficinas } & \square \text { Hortas/Pomares } & \square \text { Mirante } \\ \square \text { Sala Multiuso } & \square \text { Instalações p/ animais } & \square \text { Museu } \\ \square \text { Cozinha } & \square \text { Viveiro de Mudas } & \square \text { Loja } \\ \square \text { Refeitório } & \square \text { Trilhas } & \square \text { Outros: }\end{array}$

2.3 - Elencar as características do entorno do CEA: (quantas forem necessárias)

$\begin{array}{lll}\square \text { Rios/Córregos } & \square \text { Zoológico } & \square \text { Caatinga } \\ \square \text { Lagos } & \square \text { Zona Rural } & \square \text { Dunas } \\ \square \text { Montanha/Serras } & \square \text { Unidade de Conserv. } & \square \text { Áreas Industriais } \\ \square \text { Florestas Nativas } & \square \text { Cerrado/Savana } & \square \text { Cidade/Vila } \\ \square \text { Florestas Plantadas } & \square \text { Mar/Litoral } & \square \text { Campos } \\ \square \text { Parque } & \square \text { outra: }\end{array}$


2.4 - Quais os recursos disponíveis no CEA?:

$\begin{array}{lll}\square \text { TV } & \square \text { Mapas } & \square \text { Ranário/Formigueiro } \\ \square \text { Vídeo } & \square \text { Computador } & \square \text { Painéis Expositivos } \\ \square \text { Projetor de Slides } & \square \text { Jogos Pedagógicos } \quad \square \text { Data Show } \\ \square \text { Retroprojetor } & \square \text { Binóculos/Lunetas } \quad \square \text { Multimídia } \\ \square \text { Maquetes } & \square \text { Coleção de Insetos } \quad \square \text { Outros: }\end{array}$

2.5 - Há produção de materiais pelo CEA ?

$\begin{array}{llll}\square \text { Não } & \square \text { Sim - } & \text { Quais ? (assinalar abaixo) } & \\ \square \text { Livros } & \square \text { Panfletos } & \square \text { Cartazes } & \square \quad \text { CD-ROM } \\ \square \text { Vídeos } & \square \text { Cartilhas } & \square \text { Folders } & \square \text { Jornais } \\ \square \text { Outros: } & & \end{array}$

3) Público Atendido:

3.1 - Classificar os 3 tipos de público que mais frequentam o CEA (coloque os seguintes códigos nos parênteses: 1 p/ o mais frequente, 2 p/ médio e 3 p/ o menos frequente):

( ) Escolares ( $\left.1^{\circ} \mathrm{Grau}\right)$

( ) Escolares ( $\left.2^{\circ} \mathrm{Grau}\right)$

( ) Universitários

( ) Setores Profissionais - citar:

( ) População Local

( ) $3^{\mathrm{a}}$ Idade

( ) Turistas

( ) Grupo de Mulheres/Donas de Casa

( ) Deficientes Físicos/Mentais

( ) Outros:

3.2 - Procedência do público: (marque quantos forem necessários)

da cidade

$\checkmark$ de fora da região, mas do estado

$\square$ de fora do Brasil

$\checkmark$ de fora do município, mas da região

$\square$ de outro estado, mas do Brasil 
3.3 - Como o público visitante ficou sabendo da existência do CEA:

$\square$ já participou anteriormente de atividades no CEA $\quad \square$ através do Jornal

$\square$ indicação de pessoas/amigos $\quad \square$ Internet

$\square$ através da TV $\square$ Mala direta

através da Rádio $\square$ Contato direto do próprio CEA

Outras formas:

3.4 - Número estimado de pessoas atendidas por ano:

$\begin{array}{lll}\square \text { até } 5.000 & \square \text { de } 5.001 \text { a } 10.000 & \square \text { de } 10.001 \text { a } 15.000 \\ \square \text { de } 15.001 \text { a } 20.000 \quad \square \text { de } 20.001 \text { a } 30.000 & \square \text { mais de } 30.000\end{array}$

4) Equipe Pedagógica:

4.1 - Qtas Pessoas trabalham com remuneração no CEA ? (excluindo aquelas relativas a limpeza, segurança, etc)

4.2 - Há trabalho voluntário ? $\square$ Não $\square$ Sim - Quantas pessoas ?

4.3 - Formações dos membros da Equipe Técnica:

$\begin{array}{lll}\square \text { Biólogos } & \square \text { Eng. Florestal } & \square \text { Geólogos } \\ \square \text { Educadores/Professores } & \square \text { Médicos } & \square \text { Filósofos } \\ \square \text { Pedagogos } & \square \text { Enfermeiros } & \square \text { Eng. Civil } \\ \square \text { Agrônomos } & \square \text { Arquitetos } & \square \text { Eng. Mecânico } \\ \square \text { Geógrafos } & \square \text { Antropólogos } & \square \text { Eng. Elétrico } \\ \square \text { Historiadores } & \square \text { Sociólogos } \\ \square \text { Técnico de } 2^{\circ} \text { Grau } & \\ 4.4 \text { - Média Salarial dos membros da Equipe Técnica: } & \\ \square \text { abaixo de 2 salários mín. } & \square \text { de } 4 \text { até 6 salários mín. } & \square \text { mais de 8 salários } \\ \square \text { de 2 até } 4 \text { salários mín. } \quad \square \text { de } 6 \text { até 8 salários mín. } & \end{array}$

5) Atividades Desenvolvidas:

5.1 - Classificar as 3 intervenções mais freqüentes (colocando os seguintes códigos nos parênteses: $1 \mathrm{p} /$ mais freqüente, $2 \mathrm{p} /$ médio, $3 \mathrm{p} /$ menos freqüente):

$\begin{array}{lll}(\quad) \text { Visitas Orientadas } & (\quad) \text { Palestras } & (\text { ) Oficinas } \\ (\quad) \text { Exposições } & (\quad) \text { Cursos } & (\text { ) Pesquisa } \\ (\quad) \text { Trilhas } & (\quad) \text { Outras: } & \end{array}$


5.2 - Qual a combinação mais freqüente dessas intervenções:

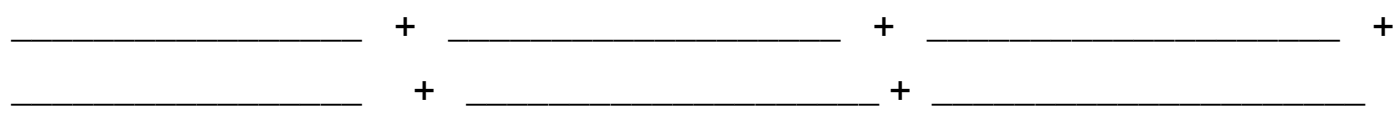

(exemplo: Visita Orientada + Palestra + Trilhas ....)

5.3 - Tais intervenções são oferecidas mais freqüentemente: (marque somente uma alternativa)

em um único dia

em mais de um dia

em ambos os casos, mas com predomínio do $1^{\circ}$

em ambos os casos, mas com predomínio do $2^{\circ}$

em ambos os casos, igualmente distribuídos

outra:

5.4 - Temas trabalhados no CEA:

$\begin{array}{lll} & \text { Meio Amb/Natureza } & \\ \square \text { Água/Rios } & \square \text { Pecuária } & \square \text { Solo/Erosão } \\ \square \text { Árvores } & \square \text { Ecoturismo } & \square \text { Fogo/Incêndios } \\ \text { Lixo/Reciclagem } & \square \text { Biodiversidade } & \square \text { Artesanato } \\ \text { Patrimônio hist./Cult. } & \square \text { Plantas Medicinais } \\ \square \text { Energias Alternativas } & \square \text { Poluição/Degradação Amb. } \\ \square \text { Interpret. da Paisagem } & \square \text { Recuperação Áreas Degrad } \\ \square \text { Agricultura } & \square \text { Saneamento Básico } \\ \square \text { Arquitetura Bioclimática } & \square \text { Apicultura }\end{array}$

Astronomia

Outros:

5.5 - Forma de pagamento das atividades:

$\square$ Totalmente Gratuíta

Parcialmente Gratuíta (gastos de deslocamento e alimentação)(desconsidere a questão 5.6)

Paga

5.6 - Valores pagos pela Visita/Estância:

até $\mathrm{R} \$$ 5/pessoa/dia $\quad \square$ de $\mathrm{R} \$ 10$ a $\mathrm{R} \$$ 20/pessoa/dia

de $\mathrm{R} \$ 5$ a $\mathrm{R} \$$ 10/pessoa/dia $\square+$ de $\mathrm{R} \$ 20 /$ pessoa/dia 
6) Utilize o espaço abaixo para:

a) Observações e outras informações que julgue importante

b) Breve avaliação do questionário 
Universidade de São Paulo - Escola Superior de Agricultura "Luiz de Queiroz" Programa de Pós Graduação em Recursos Florestais Histórico, Classificação e Análise de Centros de Educação Ambiental (CEAs) no Brasil

\section{Questionário 2}

1) Relate resumidamente como foi o início do CEA (motivos atores envolvidos, dificuldades, parcerias, etc) :

2) Elencar no máximo três principais objetivos do CEA:

Difundir/Transmitir informações/conhecimentos da área ambiental

Elaboração e execução de projetos e programas de E.A.

Despertar e promover o interesse e a sensibilização para a questão ambiental

Reflexão crítica sobre os problemas ambientais atuais

Fomentar a revisão de valores e mudança de atitudes cotidianas

Contribuir para a construção de sociedades sustentáveis

Dinamização/Mobilização local comunitária

Questionar e atuar politicamente/ideologicamente

Desenvolvimento de práticas de ecoturismo

Promover momento de descanso e lazer

Fomentar e desenvolver pesquisas no campo da E.A.

Repassar procedimentos de comportamentos ambientais sustentáveis

Formação de recursos humanos no campo da Educação Ambiental

Desenvolvimento de atividades lúdicas e culturais

Promoção de atividades de caráter desportivo

Outros 
3) Formas de Avaliação:

3.1 - das atividades desenvolvidas:

Questionário

Caderno de Campo

Reuniões com o público

3.2 - do próprio CEA:

Questionário

Caderno de Campo

Reuniões com o público
Entrevistas

Nenhuma

Livro de registro

Entrevistas

Nenhuma

Livro de registro
Observação Direta

Reuniões da equipe

Outras:

Observação Direta

Reuniões da equipe

Outras:

4) Programa Pedagógico:

4.1 - Há um programa pedagógico que norteia a atuação do CEA ?

Sim (vá para a questão 4.3)

Não (vá para a questão 4.2)

4.2 - Citar os motivos da não existência de um programa pedagógico:
falta de tempo
limitação financeira
limitação de recursos humanos
CEA muito novo

Não se faz necessário um projeto $\square$ Outros:

4.3 - Descreva em linhas gerais os principais tópicos e características do programa pedagógico do CEA (anexar, se possível, cópia dele)

5) Qual o concepção do tema Biodiversidade, e como é trabalhado no CEA ? (desconsidere a questão, se não trabalhá-lo no CEA) 


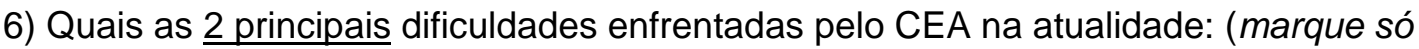

2)

$\square$ limitação financeira

$\square$ limitação de infra-estrutura e equipamentos

programa pedagógico precisa ser revisto/reelaborado

carência de público

outra:

7) Quais as 2 principais perspectivas para o CEA para os próximos 5 anos ? (marque só duas)

$\square$ Construção/ampliação da sede e dos espaços

Diversificação dos temas trabalhados

Diversificação do tipo de público atendido

Fomento à parcerias e intercâmbios

Ampliação/qualificação da equipe de trabalho

Maior divulgação do CEA

$\square$ Elaboração e Implementação de Programa Pedagógico

$\square$ Auto-suficiência financeira

Desenvolvimento de formas e agentes de avaliação

outra:

8) Utilize o espaço abaixo para:

a) Observações e outras informações que julgue importante

b) Breve avaliação do questionário limitação de recursos humanos

ausência de programa pedagógico 


\section{ANEXO B - Carta de Timóteo}

\section{Deliberações do Encontro Nacional de Centros de Educação Ambiental - ENCEA}

Realizado durante os dias 1 e 2 de outubro de 2003, o Encontro Nacional de Centros de Educação Ambiental - ENCEA - reuniu cerca de 50 pessoas, educadores e educadoras ambientais, técnicos de instituições, estudantes universitários, representantes de cerca de 20 CEAs do país, para discussão da temática, tendo como eixos fundamentais: Projeto Político Pedagógico e Rede CEAs.

O evento foi organizado pela Rede Brasileira de Centros de Educação Ambiental (Rede CEAs), pela Fundação Acesita e pelo Centro de Educação Ambiental Oikós, e contou com a parceria de diversas instituições e redes: Ministério do Meio Ambiente, Ministério da Educação, Instituto Estadual de Florestas/MG, Rede Brasileira de Educação Ambiental (REBEA), Rede Mineira de Educação Ambiental (RMEA), OCA - Laboratório de Educação e Política Ambiental (ESALQ/USP), Centro de Estudos e Pesquisas Ambientais (CEPA) ALCOA, BUNGE Fertilizantes.

O ENCEA contou com diversos espaços que possibilitaram discussões sobre os dois eixos de evento, além de atividades culturais. Também foi possível a construção coletiva de documentos, resultantes dos 4 Grupos de Trabalho oferecidos: GT-1 CEAs: Concepção e Fundamentação; GT-2 Projeto Político Pedagógico de CEAs; GT-3 Articulação entre CEAs \& Redes de EA; GT-4 CEAs em Empresas. Os documentos originados a partir desses GTs serviram de base para a constituição desta Carta de Timóteo.

\section{Concepção de Centro de Educação Ambiental:}

Entende-se como CEA um Espaço Físico de Referência em Educação Ambiental, representado por uma sede (fixa ou móvel), dotado de uma série de Equipamentos, Recursos e Outros Espaços, que conta com uma Equipe (preferencialmente multidisciplinar) capaz de desenvolver Múltiplas Atividades destinadas a públicos diferenciados e orientadas por um Projeto Político Pedagógico bem estruturado. Um CEA pode então ser dotado de uma considerável diversidade de equipamentos e de recursos, de diversas naturezas: audiovisuais, pedagógicos, de segurança, informáticos, culturais, etc. Pode também dispor ou se utilizar de outros 
espaços, além da sua sede física - que pode ser fixa ou ambulante - como por exemplo: matas, viveiros, criatório de animais, zoológicos, parques, jardins botânicos, bibliotecas, etc.

Entende-se por Projeto Político Pedagógico como sendo um Documento Estratégico com Diretrizes voltadas para a Sensibilização individual e coletiva, visando a promoção e a mudança de comportamentos para a interação sustentável entre ser humano e o ambiente. É destinado a comunidades de: Alunos, Professores, Agricultores, Visitantes de Parques e Reservas, Funcionários de Empresas, dentre outros coletivos. Todo Projeto Político Pedagógico deve partir do pressuposto de que há considerável Pluralidade Metodológica, buscando alcançar Contextualização Pedagógica com adequação da linguagem. Deve ser um Projeto Flexível para contemplar peculiaridades locais, almejando Capacitar pessoas para Participação. Reforça-se a necessidade de processos avaliativos continuados, a partir da práxis cotidiana.

Um CEA pode desenvolver múltiplas atividades como Oficinas, Trilhas, Palestras, Cursos, Eventos, Visitas Orientadas, Excursões, Estudos do Meio, etc, e apresentam também uma grande variedade de Finalidades:

1.Geração e/ou Disponibilização de Informações/Conhecimentos;

2.Sensibilização;

3.Conscientização;

4.Integração;

5.Reflexão;

6.Potencialização e instrumentalização para a ação;

7.Troca/Interação;

8.Investigação / Motivação

9.Aprendizado;

Todas estes objetivos deságuam num grande objetivo comum que é a contribuir para a melhoria da Qualidade de Vida das pessoas. Entende-se que há alguns conceitos que estão diretamente relacionados a este - Qualidade de Vida - como Cidadania, Conservação e Preservação socioambiental e Transformação de Paradigmas.

Pode-se qualificar o Momento Atual enfrentado pelos CEAs como sendo de: 
- Transformação (Ampliação De Espaço Fisico, Abrangência);

- Busca da Sustentabilidade (Econômica E Política);

- Crescimento da Demanda da Sociedade;

- Crescimento de Iniciativas de CEAs, ligadas aos diversos setores da Sociedade;

- Maior Envolvimento do Poder Público, da Iniciativa Privada e da Sociedade em Geral;

- Disposição de Certos Políticos em estimular (Utilizar A Bandeira Ecológica);

- Uso de novas tecnologias (Gps, Teleconferências, Internet, Etc).

No tocante às articulações Entre CEAs, Redes de EA e a própria Rede CEAs, tem-se Dificuldades de diversas naturezas:

- Comunicação;

- Desconhecimento dos CEAs sobre a existência das Redes;

- Acesso à Internet;

- Volume excessivo de Informações;

- Espaço institucional para articulação com as Redes (Tempo e Recursos Humanos);

- Desconhecimento do conceito e da prática de Redes;

- Recursos Financeiros;

- Falta de interesse das pessoas e instituições em participar das Redes;

Algumas Alternativas são delineadas visando o enfrentamento das dificuldades:

- Fortalecimento das Redes já existentes;

- Encontros Presenciais (Eventos e Reuniões) em âmbito local, regional e nacional com maior freqüência, de acordo com a demanda e as Possibilidades. Destacando na programação com Espaços de interação, visitas e vivências;

- Ampliação dos canais de comunicação: Revistas, Artigos, Informativos, Telefones, Fax, etc;

- Projeto de inclusão digital dos CEAs;

- Capacitação para o trabalho em Rede; 
- Descentralização das Redes;

- Definição de papéis a serem desempenhados nas Redes com estabelecimento de critérios a serem seguidos. Ex: Secretaria Executiva;

- CEAs contribuírem para facilitar as Redes Regionais de EA;

- Formar Grupos Temáticos de CEAs nas Redes Estaduais;

- Formar Grupos Temáticos de CEAs dentro aa Rede CEAs. Ex: GT De Políticas Públicas, GT de CEAs de Empresas, etc;

- Possibilitar o financiamento público e privado para a consolidação E o fortalecimento das Redes de EA;

- Sensibilizar os dirigentes das instituições para a importância das Redes de EA e da Rede CEAs.O Encontro Nacional dos Centros de Educação (ENCEA) finalizou seus trabalhos delibarando durante Plenária Final algumas Propostas de Ação com suas respectivas estratégias de Encaminhamento:

1-Carta de Timóteo (disponível para discussão na Rede CEAs - prazo 20 dias para consultas, deliberações e alterações no documento). Após, será encaminhado à Redes de EA, órgãos governamentais e não governamentais, empresas, dentre outras entidades proponentes e gestoras de CEAs no país;

2- Linha de Publicação Impressa e em Vídeo sobre a temática dos CEAs e trazendo resultados do ENCEA (Grupo Responsável: Aluísio (PBH-RMEA), Déborah(FIEMGRMEA), Mônica (MBR/AMDA-RMEA), Paulo (ALCOA), Lílian (AÇOMINAS), Alexandre (OCA-REDECEAS), Maurício (OIKÓS);

3- Da Carta de Timóteo desdobrar ações específicas propostas (Ex.: Encontros presenciais, Redeceas, Redes De Ea, Instâncias Governamentais Correlatas);

4- Inserir Link da Rede CEAs no SIBEA (Marcos Sorrentino - Divisão de Educação Ambiental / MMA);

5- Rede CEAs promovendo Diagnóstico Continuado das ações desenvolvidas pelos CEAs. (Mais informações no site da Rede CEAs);

6- Realização do próximo ENCEA para Maio/2004, e sendo organizado, de preferência, anualmente. Não foi definido o local (Estado/Cidade) do próximo ENCEA, e não houve comunicação oficial por parte de qualquer instituição presente quanto à organização do próximo Encontro. 
Timóteo - MG, 2 de outubro de 2003.

Redação: Coordenação do ENCEA (Rede CEAs, CEA - Oikós/Fundação Acesita, Rede Mineira de Educação Ambiental - RMEA)

Rede CEAs - www.redeceas.esalq.usp.br

redeceas@esalq.usp.br

CEA - Oikós (Fundação Acesita)

faoikos@uai.com.br

Rede Mineira de Educação Ambiental (RMEA)

ddama@pbh.gov.br 


\section{ANEXO C - Relação dos Centros de Educação Ambiental que colaboraram com este estudo (organizados em ordem alfabética por Estado em cada região)}

\section{$\underline{\text { Região Norte }}$}

\section{Acre}

Rede Acreana de EA - UFAC

Parque Zoobotânico

BR - 364 - Km 4 - Distrito Industrial - Rio Branco - AC

CEP: $69915-900$

educacaoambiental@ufac.br

$68-229-1642$

\section{Amazonas}

Gerência de Educação Ambiental, Informação e Comunicação (GEIC)

Rua Recife, 3280 - Parque Dez - Manaus - AM

geic@ipaam.br

$92-643-2307$

\section{Pará}

Programa de Educação Ambiental - Projeto Várzea (IPAM)

Av. Rui Barbosa, 136 - Santarém - PA

CEP: $68005-080$

$93-522-5538$

ipam@tap.com.br

\section{Tocantins}

Programa de Educação Ambiental - UHE Luis Eduardo Magalhães (Lageado)

SOII, 103 Sul, Cj. 03 - Lt. 28 - $2^{\circ}$ Piso - Palmas - TO

CEP: $77173-020$

$63-215-7472$

pealecologia@uol.com.br

\section{$\underline{\text { Região Nordeste }}$}

\section{Bahia}

RPPN Estação Veracruz

Rod. BR 367 - Cx. Postal 21 - Eunápolis - BA

CEP: $45820-900$

www.veracel.com.br

73-281-8052 Fax: 281-8070 
Associação Cultural Arte e Ecologia - ASCAE

Rua Nova, 36 - Santa Cruz Cabrália - BA

$73-282-1355$

ascae@rm10.com.br

CEA Protagonismo Juvenil - PANGEA

Av. Pinto de Aguiar, s/n - Salvador - BA

pangea@svn.com.br

$71-9962-6826-321-3201$

\section{Ceará}

Centro de Articulação e Educação Ambiental - CAEA

Rua Cel. José Nunes, 953 - Limoeiro do Norte - CE

CEP: $62930-000$

$88-423-4451$

Oficina de Educação Ambiental

Parque Nacional Ubajara

Rod. Da Confiança - CE - 187 - Ubajara - CE

CEP: $62350-000$

pnubajara@bol.com.br

\section{Maranhão}

Associação Miradorense dos Ecologistas - AME

Rua das Palmeiras, s/n - Centro - Mirador - MA

CEP: $65850-000$

$99-556-1233$

\section{Paraíba}

Programa de Educação Ambiental "Ribinho Verde: Conscientização e Integração da Comunidade com o Meio Ambiente"

Rod. PB - 065 - km. 25 - Mataraca - PB

CEP: 58292-000

rcastro@mic-br.com.br

83 - 297-3861 - 297-3845 Fax: 297-3860

Grupo Verde de Ecologia e de Preservação Ambiental

Rua Elzir Matos, 100 - Centro - Piancó - PB

CEP: $58765-000$

aldonet@bol.com.br

$83-452-2679$

\section{Pernambuco}

Unhaú - Centro de Educação Ambiental

Rua Napoleão Galvão, 605 - Centro - Garanhuns - PE

CEP: 55296-010

87 - 3762-1322 Fax: 3762-3722 - 9115-6086 
Núcleo de Educação Ambiental - NEA - IBAMA/PE Av. 17 de agosto, 1057 - Casa Forte - Recife - PE CEP: 52060-590

gilmarib@bol.com.br

81 - 3441-6460 / 5075 Fax: 3441-2532

Piauí

15) Núcleo de Educação Ambiental (NEA) / IBAMA/PI Av. Homero Castelo Branco, 2240 - Teresina - PI CEP: 64048-401

alustosa@uol.com.br

86 - 233-3369 Fax: 232-5323

\section{Rio Grande do Norte}

Gerência de Qualidade do Produto e Meio Ambiente Av. Senador Salgado Filho, 1555 - Tirol - Natal - RN CEP: 59056-000

gqm@caern.com.br $84-232-4169$ / 232-4166

\section{Sergipe}

Núcleo de Educação Ambiental - NEA - IBAMA/SE

Av. Ivo do Prado, 840 - Centro - Aracaju - SE

maassrei@bol.com.br

79 - 211-1575 / 211-1573 / 211-0468

\section{Região Centro-Oeste}

Distrito Federal

Centro de Desenvolvimento Sustentável - SDS - UnB

Setor de Autarquia Sul (SAS) - Q. 5 - BI. $\mathrm{H}-2^{\circ}$ andar - Brasília - DF CEP: $70910-900$

$61-307-3210-323-3680$

Divisão de Educação Ambiental

Jd. Botânico de Brasília - SMDB - Cj. 12 - Lago Sul - Brasília - DF CEP: $71680-120$

61 - 366-4482 Fax: 366-3831

Divisão de Educação Ambiental - Departamento de Divulgação Científica Edifício Sede - IBAMA

SAIN - L4 N - BI. B - Sala 18 - Brasília - DF

CEP: $70800-200$

$61-226-5615$ / 316-1189 


\section{Goiás}

Forte Dr. Sulivan Silvestre

Estrada do Arieão, km 5 - Área Rural - Aparecida de Goiânia - GO

CEP: $74000-000$

amigosverdes@ig.com.br / semma@goiania.go.gov.br

$62-584-6043$

$A B C$ - S Ecolinha do Saneamento (SENAGO)

Av. Perimentral Norte - s/n - Setor Goiânia II - Goiânia - GO

CEP: 74665-510 62 - 522-2722 Fax: 522-2724

Núcleo de Educação Ambiental - NEA - IBAMA/GO

Rua 229, n. 95 - Setor Universitário - Goiânia - GO

CEP: 74605-090

ibama@go.ibama.gov.br

62 - 224-2488 Fax: 225-5035

24) Centro de Desenvolvimento Agroecológico do Cerrado (CEDAC)

Rua C - 233, Q. 572 - Lt. 02 - Nova Suíça - Goiânia - GO

CEP: $74290-040$

cedac@cedac-ong.org.br / cedac@cedac.org.br

$62-251-4075$ / 6281

25) Centro de Apoio à Pesquisa e Educação Ambiental

Reserva Flor das Águas - Pirenópolis - GO

www.funatura.org.br

$61-274-5449$ (Funatura)

\section{Mato Grosso do Sul}

26) PratiquEcologia - Conscientização Ecológica

Rua Maracaju, 997 - Centro - Campo Grande - MS

CEP: 79002-211

pratiquecologia@ig.com.br

$67-3025-5305$

\section{Mato Grosso}

27) Núcleo de Educação Ambiental (NEA) / IBAMA/MT

Av. Historiador Rubens de Mendonça, s/n - CPA - Cuiabá - MT

CEP: $78055-500$

guilu@zaz.com.br

$65-648-9100$ 


\section{$\underline{\text { Região Sudeste }}$}

\section{Espírito Santo}

Centro Estadual Integrado de Educação Rural de Boa Esperança

Rod. Boa Esperança - São Mateus - Km 3 - Boa Esperança - ES

Cx. Postal 29 - CEP: 29845-000

$27-3768-1290$

cir@simonet.com.br

Pólo de Educação Ambiental

Mosteiro Zen Morro da Vargem - Ibiraçu - ES

CEP: $29670-000$

$27-3267-1150$

Museu de Biologia Professor Mello Leitão

Av. José Ruschi, 4 - Centro - Santa Teresa - ES

CEP: 29650-000

$27-3259-1182$

ruschi@terra.com.br

CEA - CST Escolas

Av. Brig. Eduardo Gomes, 930 - Serra - ES

CEP: 29163-970

centroeudcacaoambiental@tubarao.com.br

$27-3348-1594$

Núcleo de Educação Ambiental - NEA - IBAMA/ES

Av. Mal. Mascarenhas de Moraes, 2487 - Bento Ferreira - Vitória - ES

CEP: 29052-121

27 - 3324-1811 - Fax: 3235-8102

ibere.sassi@ibama.gov.br

nea@es.ibama.gov.br

CEA - Parque Municipal de Barreiros

Rod. Serafim Derenzi, s/n - São Cristóvão - Vitória - ES

CEP: 29000-000

$27-3382-6598$

plaurentino@bol.com.br

CEA "Gruta da Onça"

Rua Barão de Monjardim - Cento - Vitória - ES

CEP: 29000-000

$27-3132-7290$

Parque da Pedra da Cebola

Rua João Batista Celestino, s/n - Mata da Praia - Vitória - ES

CEP: 29000-000

$27-3327-4298$ 
Parque da Fonte Grande

Av. Tião Sá, s/n - Vitória - ES

CEP: $29000-000$

$27-3381-3521$

CEA Taleuazeiro

Rua Jácomo Forza, s/n - Taleuazeiro - Vitória - ES

CEP: $29000-000$

$27-3132-7291$

CEA do Parque Municipal Padre Alfonso Pastore

Rua João Honorato Rodrigues, s/n - Vitória - ES

CEP: 29065-470

Ivent@uol.com.br

$27-3382-6599$

Parque da Baía Noroeste

Rua da Coragem, s/n - Redenção - Vitória - ES

27 - 3381-6977

Parque Moscoso

Av. José de Anchieta, s/n - Parque Moscoso - Vitória - ES

27 - 3381-6819 / 3233-4311

\section{Minas Gerais}

Centro de Desenvolvimento Ambiental (CBMM)

Córrego da Mata, s/n - Cx. Postal 8 - Araxá - MG

CEP: $38180-000$

Laura@cbmm.com.br

$34-3669-3511$ / 3669-3500

CEA - Parque Municipal Américo René Giannetti

Av. Afonso Pena, s/n - Centro - Belo Horizonte - MG

CEP: $30130-002$

31 - 3277-4381 - 3273-2001

Casa de Educação Ambiental

Av. Otacílio Negrão de Lima, 8000 - Pampulha - Belo Horizonte - MG

CEP: 31365-450

fzbeduc@pbh.gov.br

$31-3277-7287$ / 7286 Fax: 3277-7258

CEA "Aimirim"

Rod. BR - 040, km 790 - Juiz de Fora - MG

Cx. Postal 763 - CEP: 36001-970

amajf@terra.com.br / www.proecologia.com.br

$32-3236-4487$ 
Casa da Natureza

Rod. BR - 040, km 769 - Dias Tavares - Juiz de Fora - MG

CEP: 36105-000

Casa.natureza@belgo.com.br

$32-3229-1319$

CEA Menino Maluquinho

Av. J.K., 10000 - Barreira do Triunfo - Juiz de Fora - MG

CEP: $36092-060$

$32-3690-7887$

CEA "Harry Oppenheimer"

Rua Aldo Zanini, s/n - Fazenda Rappanhua - Nova Lima - MG

CEP: $34000-000$

cea@anglogold.com.br

31 - 3589-2292 / 3542-9304

Centro de Estudos e Pesquisas Ambientais - CEPA - ALCOA

Cx. Postal - 128 - Poços de Caldas - MG

CEP: 37701-970

Paulo.Junqueira@alcoa.com.br

$35-3713-2132-2400$

Núcleo de Educação Ambiental - Parque Estadual do Rio Doce

Rua Araribá, 300 - Recanto Verde - Timóteo - MG

CEP: $35180-000$

perdoce@facil.psi.br

$31-3822-3006$

Centro de Agricultora Alternativa "Vicente Nica" (CAV)

Rua São Pedro, 43 - Campo - Turmalina - MG

CEP: 39660-000

cavi@turmalinaonline.com.br / cavi@ligbr.com.br

$38-3527-1401 / 1658$

Rio de Janeiro

Núcleo de Educação Ambiental - Parque Nacional do Itatiaia

Parque Nacional do Itatiaia - Centro de Visitantes - Cx. Postal 83657

CEP: 27580-970 - Itatiaia - RJ

24 - 3352-1461 Fax: 3352-1652

Núcleo Interdisciplinar de Meio Ambiente (NIMA - PUC)

Rua Marquês de São Vicente, 225 - Ed. Padre Leonel Franca $-7^{\circ}$ Andar CEP: 22453-900 - Gávea - Rio de Janeiro - RJ

Josefa@geo.puc-rio.br

$21-3114-1463$ 
Centro de Capacitação Ambiental Terrazul

Ilha da Glória - casa 18 - Barra da Tijuca - Rio de Janeiro - RJ

CEP: 22640-310

terrazul@unisys.com.br

21 - 2494-7755 - 2493-5770

Bicuda Ecológica

Rua Tolentino da Silva, 40 - Penha - Rio de Janeiro - RJ

CEP: 21221-100

$21-3352-1245$

bicuda@bicuda.org.br

Núcleo de Educação Ambiental (NEA)

Rua Jardim Botânico, 1008 - Rio de Janeiro - RJ

CEP: 22460-000

nea@jbri.gov.br

$21-2259-6551$

Centro de Educação Ambiental

Rua Afonso Cavalcanti, 455 - Cidade Nova - Rio de Janeiro - RJ

CEP: 20211-110

cea@pcri.ri.gov.br / mmonteir@pcri.ri.gov.br

$21-2504-5672$ / 2503-2979

CEA da Reserva da Cicuta

Rua 21, s/n - Vila Santa Cecília - Volta Redonda - RJ

CEP: $27269-900$

24 - 3344-3009 - 3344-6473

marciomeira@csn.com.br

São Paulo

Sítio Duas Cachoeiras - Educação e Agricultura (SDC)

Distrito de Arcadas - Amparo - SP

CEP: 13908-009

www.sitioduascachoeiras.com.br

$19-3807-1230$

Casa da Ecologia - Instituto Pau Brasil

Av. Benedito Manoel dos Santos, 369 - Cx. Postal 282 - Arujá - SP

CEP: 07400-970

info@institutopaubrasil.org.br

11 - 4652-5262 / 4655-2731

CEA "Horácio Frederico Pyles" - Zoo de Bauru

Av, Nuno de Assis, 14-60 - Bauru-SP

CEP: $17020-310$

16 - 235-1185 / 1143 Fax: 235-1135

www.zoobauru.kit.net 
Associação Ibiraci (Al)

Estrada Buri-Paranapanema, km 26 - Cx. Postal 81 - Buri - SP

CEP: $18290-970$

produtos@covembare.com.br

15 - 3646-9499 Fax: 3436-9500

Núcleo de Pesquisa e Desenvolvimento - Jardim Botânico (IAC)

Av. Barão de Itapura, 1481 - Cx. Postal 28 - Campinas - SP

CEP: 13001-970

rachelgo@iac.br

19 - 3231-5422 ramal 222/178 Fax: 3231-4943

Mata Santa Genebra - Fundação José Pedro de Oliveira

Rua Mata Atlântica, 447 - Bosque do Barão - Campinas - SP

CEP: 13083-724

fundacaojpo@hotmail.com / www.santagenebra.org.br

$19-3289-2886$

Núcleo Perequê

Parque Estadual da llha do Cardoso

Av. Prof. Wladmir Besnard, s/n - Cx. Postal 43 - Cananéia - SP

CEP: $11990-000$

peic@rgt.matrix.com.br

$13-6851-1108 / 1163$

CEA de Guarulhos (CEAG)

Rua João Marcelo Santoni, 295 - Parque Renato Maia - Guarulhos - SP

CEP: 07114-120

ceag@terra.com.br

$11-6461-1383$

Programa de Educação Ambiental "Conhecer para Preservar"

Rod. Washington Luiz, km 257 - Ibaté - SP

CEP: $14815-000$

ripasafortaleza@uol.com.br

$16-243-1621 / 1622$

Trilha Ecológica Tapixingui

Rod. Francisco Alves Negrão, km 342,5 - Itararé - SP

CEP: 18460-000

secetitarare@bol.com.br

$15-3531-1567$

Trilha Ecológica - Fazenda Ibiti (Ripasa)

Fazenda Ibiti, s/n - Itararé - SP

CEP: $18000-000$

ripasaibiti@fis.com.br

$15-532-4037$ 
CEA - Zoológico Municipal de Mogi Mirim

Rua Vereador Simão Ferreira Alves, 11 - Jd. Primavera - Mogi Mirim - SP CEP: $13801-525$

zoomogimirim@ig.com.br

$19-3805-4730$

Parque Florestal São Marcelo

Rod. SP - 340 - Km 171 - Mogi Guaçu - SP

$19-3861-8638$

Museu da Água

Av. Beira Rio, s/n - Centro - Piracicaba - SP

CEP: $13416-756$

sgava@semaepiracicaba.org.br

19 - 3403-9611 ramal 9666 / 3403-9602 Fax: 3426-0584

CEA Promissão

Rod. BR - 153 - km 139 - Promissão - SP

Cx. Postal 71 - CEP: $16370-000$

Jose.simionato@aes.com

14 - 3543-9926 / 9928 Fax: 541-0521

Centro de Apoio à Educação Ambiental de Ribeirão Preto

Rua Liberdade, s/n - Bosque Municipal - Ribeirão Preto - SP

CEP: $14085-250$

educacaoambiental@ribeiraopreto.sp.gov.br

$16-636-2283$ / 2545 / 2715

Centro de Educação Ambiental do Ribeirão Verde

Estrada das Palmeiras, s/n - Jd. Florestan Fernandes - Ribeirão Preto - SP

CEP: $14079-320$

Kamikaze.endo@lycos.com

$16-9992-5701$

Centro de Análise e Planejamento Ambiental (CEAPLA)

Av. 24 - A, 1515 - IGCE - UNESP - Campus da Bela Vista - Rio Claro - SP

Cx. Postal: 178 - CEP: 13506-900

ceapla@rc.unesp.br

$19-524-9622$

Parque Estadual "Carlos Botelho"

Rod. SP - 139, Bairro Abaitinga - Cx. Postal 37 - São Miguel Arcanjo - SP

CEP: $18230-000$

pecarlosbotelho@ig.com.br

15 - 3379-4278 / 1477 
Divisão de Ensino e Divulgação - Zôo de SP

Av. Miguel Stéfano, 4241 - Água Funda - São Paulo - SP

CEP: 04301-905

ensinazoo@zoologico.sp.gov.br

11 - 5073-0811 ramal 2127

CEA do Parque Ecológico do Tietê

Rua Guira Acangatara, 70 - Penha - São Paulo - SP

CEP: 03719-000

11 - 6958-1477 ramal 213

SENAC - Centro de Educação Ambiental

Av. Do Café, 298 - Jabaquara - São Paulo - SP

CEP: 04311-000

11 - 5017-0697 Fax: 5017-2910

cea@sp.senac.br

5 Elementos - Instituto de Educação e Pesquisa Ambiental Rua Caio Graco, 379 - Pompéia - São Paulo - SP

www.5elementos.org.br

$11-3871-1944$

Núcleo Regional de Educação Ambiental

Praça Marília, 1544 - Teodoro Sampaio - SP

CEP: $19280-000$

pmts@pmts.com.br

18 - 282-1624 Fax: 282-1321

Núcleo Picinguaba - Parque Estadual da Serra do Mar

Rod. BR - 101, km 8 - Núcleo Picinguaba - Ubatuba - SP

Cx. Postal 157 - CEP: $11680-000$

npic@iconet.com.br

$12-3832-9062$

\section{$\underline{\text { Região Sul }}$}

Paraná

Grupo Ambientalista Interdisciplinar de Apucarana - GAIA

Rua Miguel Semeão, 447 - Apucarana - PR

CEP: $86800-260$

Tel. $43-422-7888$

CEA Gralha Azul

Rua Fortunato Bebber, 2307 - Cascavel - PR

CEP: 85810-011

zoológico@cascavel.pr.gov.br

45 - 227-0303 Fax: 227-4488 
Centro de Educação Ambiental Mananciais da Serra

Rua Eng. Rebouças, 1376 - Rebouças - Curitiba - PR

CEP: 80215-900

Gema-ceam@sanepar.com.br

41-673-3310 Fax: 673-6504

Núcleo Interdisciplinar de Meio Ambiente (NIMAD - UFPR)

Centro Politécnico - UFPR - Jd. América - Curitiba - PR

Cx. Postal 19023 CEP: 81531-970

nimad@ufpr.br

$41-366-2723$

Universidade Livre do Meio Ambiente - UNILIVRE

Rua Victor Benato, 210 - Pilarzinho - Curitiba - PR

CEP: 82120-110

41 - 254-5548 - 254-7657 Fax: 335-3443

cursos@unilivre.org.br

88) Estação Natureza

Av. Sete de Setembro, 2775 - Centro - Curitiba - PR

CEP: 80230-010

estacaonatureza@fundacaoboticario.org.br

$41-232-8091 / 322-5180$

89) CEA

Rua Gal. Rondon, s/n - Anexo ao terminal Nova Rússia - Ponta Grossa - PR

CEP: $84070-000$

$42-227-7948$

90) Núcleo de Estudos em Meio Ambiente - NUCLEAM - UEPG

Praça Santos Andrade, s/n - Ponta Grossa - PR

CEP: 84010-919

nucleam@uepg.br

42 - 220-3438 Fax: 220-3342

91) Museu Regional do Iguaçu

UHE Gov. Ney Braga - Reserva do Iguaçu - PR

CEP: 85195-000

Museu.iguacu@copel.com

42 - 635-4000 ramal 2360 Fax: 635-2524

92) CEA - Parque Ecológico Klabin

Fazenda Monte Alegre - Lagoa - Telâmaco Borba - PR

CEP: 84279-000

Vlamir@klabinpr.com.br

$42-271-2378$ / 2383 
Linha Ecológica: Educação Ambiental e Tecnologia Rural (CEA Móvel)

45 - 268-2489 / 520-5817 (Ecomuseu de Itaipu)

vitorass@itaipu.gov.br

\section{Rio Grande do Sul}

Centro de Estudos Costeiros, Limnológicos e Marinhos (CECLIMAR - UFRGS)

Av. Tramandaí, 976 - Centro - Imbé - RS

CEP: $95625-000$

ceclimar@ufrgs.br

$51-627-1309$

Museu Zoobotânico Augusto Ruschi (UPF)

ICB - Prédio B - 4 - Campus Universitário - Passo Fundo - RS

Cx. Postal 611 - CEP: 99001-970

muzar@upf.tche.br

$54-316-8316 / 8125$

Centro de Estudos Ambientais (CEA)

Rua General Neto, 1051 - Sala 301 - Pelotas - RS

CEP: $96015-280$

ceaong@uol.com.br

$53-225-4954$

Centro de Apoio ao Pequeno Agricultor (CAPA)

Rua Barão de Santa Tecla, 569 - Pelotas - RS

CEP: $96010-140$

capasul@terra.com.br

$53-272-3930$

Rincão Gaia

Rua Jacinto Gomes, 39 - Santana - Porto Alegre - RS

CEP: $90040-270$

fundgaia@terra.com.br

51 - 3330-3567 / 3331-3105

\section{Santa Catarina}

Jardim das Florestas

Estrada Geral - Alto Dona Luiza - Atalanta - SC

CEP: 88410-000

jardimdasflorestas@bol.com.br

47 - 521-0326 / 535-0119

100) Museu de Ecologia Fritz Muller

Rua Itajaí, 2195 - Vorstadt - Blumenau - SC

CEP: 89015-200

$47-326-6890$ 
Centro de Visitantes - Parque Estadual da Serra do Tabuleiro Rod. BR - 101, km 238 - Palhoça - SC

CEP: $88000-000$

fatma@fatma.sc.gov.br

$48-9901-9885$ / 224-829 


\section{REFERÊNCIAS BIBLIOGRÁFICAS}

BARBOSA, J.B. Multirreferencialidade nas ciências e na educação. São Carlos: EdUFSCar, 1998.

BONDÍA, J.L. Notas sobre a experiência e o saber de experiência. Revista Brasileira de Educação, n.19, p.20-29, jan./abr. 2002.

BRANDÃO, C.R. O que é educação. 26.ed. São Paulo: Brasiliense, 1991.

BRANDÃO, C.R. O ambiente, o sentimento e o pensamento: dez rascunhos de idéias para pensar as relações entre eles e o trabalho do educador ambiental. In: FÓRUM DE EDUCAÇÃO AMBIENTAL, 4.; ENCONTRO DA REDE BRASILEIRA DE EDUCAÇÃO AMBIENTAL, 1., Guarapari, 1997. Cadernos. Rio de Janeiro: INESC, 1997. p.17-38.

BRASIL. Leis, decretos, etc. Portaria n 77-N. Diário Oficial, 14 jul. 1992. Seção 1, R-9128.

BRASIL. Ministério da Educação e do Desporto. Proposta para implantação de centro de Educação Ambiental. Brasília, 1991. 18p.

BRASIL. Ministério da Educação e do Desporto. Instituto Nacional de Estudos e Pesquisas Educacionais (INEP). Centros de Educação Ambiental. Brasília, 1992. (Série Encontros e Debates) 
BRASIL. Ministério da Educação e do Desporto. Centro de Educação Ambiental: fundamentação e diretrizes. Brasília, 1994. 12p.

BRASIL. Ministério da Educação e do Desporto. Desenvolvimento e Educação Ambiental. Brasília: INEP, 1992.

BRASIL. Ministério da Educação e do Desporto Programa Nacional de Educação Ambiental - PRONEA. Brasília: UNESCO, 1997.

BRASIL. Ministério da Educação e do Desporto. Il encontro nacional de centros de Educação Ambiental: lista de participantes. Brasília, 1996.

BUSSMANN, A.C. O projeto politico-pedagógico e a gestão da escola. In: VEIGA, I.P.A. (Org.). Projeto político-pedagógico da escola: uma construção possível. Campinas: Papirus, 1999. p.37-52.

CARVALHO, I.C.M. As transformações na cultura e o debate ecológico: desafios políticos para a educação ambiental. In: PÁDUA, S.M. (Org.). Educação Ambiental: caminhos trilhados no Brasil. Brasília: IPÊ, 1997. p.271-280.

CARVALHO, I.C.M. A invenção ecológica: narrativas e trajetórias da educação ambiental no Brasil. Porto Alegre: Ed. UFRGS, 2001.

CASCINO, F. Educação Ambiental: princípios, história, formação de professores. São Paulo: SENAC, 1999.

CID, O. Equipamientos escolares. Cuadernos de Pedagogia, n.204, p.18-22,1992.

CID, O. Equipamientos para la Educación Ambiental: nuevos retos. Revista Ciclos, n.3, p.4-8, 1998.

COSTA, L.S.F.; FURNIVAL, A.C.; KRAUSS, P.P. Informação para Educação Ambiental: proposta para criação de um centro de referência. In: SEMINÁRIO 
CIÊNCIA E DESENVOLVIMENTO SUSTENTÁVEL, São Paulo, 1997. Anais. São Paulo: USP, 1997. p.301-309.

CZAPSKI, S. A implantação da Educação Ambiental no Brasil. Brasília: Ministério da Educação e do Desporto, Coordenação de Educação Ambiental, 1998.

DEMO, P. Avaliação qualitativa. 7.ed. Campinas: Autores Associados, 2002.

DIAS, G.F. Educação Ambiental: princípios e práticas. 5.ed. São Paulo: Global, 1998.

ESTRATÉGIAS ANDALUZA DE EDUCACIÓN AMBIENTAL, 2003. 125 p.

FAZENDA, I. (Org.). Metodologia da pesquisa educacional. 7.ed. São Paulo: Cortez, 2001. .

FERNANDES, L.T.O. Analysis of the Conservation Education Programme at EDC CBMM and recomendations for improvements. Jersey, 2002. Monografia (Especialização) - Kent University.

FERREIRA, L.C. A questão ambiental: sustentabilidade e políticas públicas no Brasil. São Paulo: Jinking Editores, 1998.

FREIRE, P. Criando métodos de pesquisa alternativa: aprendendo a fazê-la melhor através da ação. In: BRANDÃO, C.R. (Org.). Pesquisa participante. 8.ed. São Paulo: Brasiliense, 1990. p.34-41.

FREIRE, P. Pedagogia do oprimido. 26.ed. Rio de Janeiro: Paz e Terra, 1999.

FREIRE, P. Pedagogia da indignação: cartas pedagógicas e outros escritos. 4.ed. São Paulo: EdUNESP, 2000. 
FREIRE, P. Pedagogia da autonomia: saberes necessários à prática educativa. 22.ed. São Paulo: Paz e Terra, 2002.

GADOTTI, M. Convite à leitura de Paulo Freire. 2.ed. São Paulo: Scipione, 1991.

GADOTTI, M. Papel do planejamento na construção do projeto políticopedagógico da escola. São Paulo: Instituto Paulo Freire, 1998.

GANDIN, D. Temas para um projeto político-pedagógico. Petrópolis: Vozes, 2000.

GARCIA, B.Z. A construção do projeto político-pedagógico da escola pública na perspectiva da teoria da ação comunicativa de Jürgen Habermas. São Paulo, 1999. Dissertação (Mestrado) - Faculdade de Educação, Universidade de São Paulo.

GAUDIANO, E.G. Centro y periferia de la Educación Ambiental: un enfoque antiesencialista. 1.ed. Cuauhtémoc: Mundi Prensa México, 1998.

GAUDIANO, E.G. Otra lectura a la histria de la educación ambiental en América Latina y el Caribe. Tópicos de Educación Ambiental, v.1, n.1, p.9-26, 1999.

GAUDIANO, E.G. Revisitando la historia de la educación ambiental. In: SAUVÉ, L. (Org.). Textos escolhidos em Educação Ambiental: de uma América à outra. Montréal: Les Publications ERE-UQAM, 2002. p.23-37.

CENEAM. Guia de recursos para la educación ambiental: base de dados de equipamentos y materiales. 2001.

HABERMAS, J. Consciência moral e agir comunicativo. Rio de Janeiro: Tempo Brasileiro, 1989. 236p. 
JORNADAS DE EDUCACIÓN AMBIENTAL, 2., Valsaín, 1987. Anais. Valsaín: Ministerio de Obras Publicas y Urbanismo, Secretaria General Tecnica, Centro de Publicaciones, 1987. 106p.

LAYRARGUES, P.P. Educação no processo de gestão ambiental: criando vontades políticas, promovendo a mudança. In: SIMPÓSIO SUL BRASILEIRO DE EDUCAÇÃO AMBIENTAL, 1., Erechim, 2002. Anais. Erechim: EdiFAPES, 2002. p.127-144.

LEIS, H.R. O labirinto: ensaios sobre ambientalismo e globalização. São Paulo: GAIA; Blumenau: Fundação Universidade de Blumenau, 1996.

LIBÂNEO, J.C. Democratização da escola publica: a pedagogia crítico-social dos conteúdos. 5.ed. São Paulo: Loyola, 1987.

LIMA, G.F. da C. Crise ambiental, educação e cidadania: os desafios da sustentabilidade emancipatória. In: LOUREIRO, F.B. (Org.). Educação Ambiental: repensando o espaço da cidadania. São Paulo: Cortez, 2002. p.109141.

LONDRES, F.C.; SILVA, F.D.; SORRENTINO, M. Um estudo sobre centros de Educação Ambiental no Brasil. Revista Eletrônica do Mestrado em Educação Ambiental, v.9, p.67-82, jul./dez. 2002.

LUNA, S.V. O falso conflito entre tendências metodológicas In: FAZENDA, I. (Org.). Metodologia da pesquisa educacional. 7.ed. São Paulo: Cortez, 2001. p.2133.

MACHADO, A. Poesias completas. Madrid: Espasa-Calpe, 1973.

MAFRA, H. O movimento ambientalista brasileiro: desafios e oportunidades. 1993. 
MARTINS, J. A pesquisa qualitativa. In: FAZENDA, I. (Org.). Metodologia da pesquisa educacional. 7.ed. São Paulo: Cortez, 2001. p.47-58.

MCCORMICK, J. Rumo ao paraíso: a história do movimento ambientalista. Rio de Janeiro: Relume Dumará, 1992.

MENEZES, L.C. Razões e elementos para uma revisão do projeto pedagógico de escola. São Paulo: Cortez, 1999.

MERGULHÃO, M.C. Zoológico: uma sala de aula viva. São Paulo, 1998. Dissertação (M.S.) - Faculdade de Educação, Universidade de São Paulo.

NICOLESCU, B. O manifesto da transdisciplinaridade. São Paulo: TRIOM, 1999.

PADILHA, P.R. Planejamento dialógico: como construir o projeto políticopedagógico da escola. 2.ed. São Paulo: Cortez; Instituto Paulo Freire, 2002.

PÁDUA, J.A. Natureza e projeto nacional: nascimento do ambientalismo brasileiro (1820-1920). In: SVIRSKY, E. (Org.). Ambientalismo no Brasil: passado, presente e futuro. São Paulo: Instituto Sócioambiental, 1997. p.13-18.

PAZOS, A.S.; PORTO, H.M.P. Recursos e equipamentos de Educación Ambiental: unha aproximación á realidade galega. 2001.

PEDRINI, A.G. (Org.). Educação Ambiental: reflexões e práticas contemporâneas. Petrópolis: Vozes, 1997.

PÉREZ, J.G. La calidad educativa de los equipamientos ambientales, un debate necesario. In: JORNADAS DE EDUCACIÓN AMBIENTAL EN CASTILLA Y LEÓN, AGUILAR DE CAMPO, 2., Salamanca. Anais. Salamanca: Gráficas Varona, 1994. p.35-51. 
PÉREZ, J.G. Evalución de la calidad educativa de los equipamientos ambientales. Madrid: Ministerio de Obras Públicas, Transportes y Medio Ambiente, Centro de Publicaciones, 1995. 95p.

PÉREZ, J.G. Conclusiones grupo de trabajo: equipamientos para la Educación Ambiental: hacia la calidad educativa. In: JORNADAS DE EDUCACIÓN AMBIENTAL EN CASTILLA Y LEÓN, 2. Consejería del Medio Ambiente y Ordenación del Territorio, 1998. p. 253-59.

PIZZI, P.A. (Coord.). Ecolista: cadastro nacional de instituições ambientalistas. 2.ed. Curitiba: WWF/ Mater Natura, 1996.

QUINTÃO, A.T.B. Evolução do conceito de Parques Nacionais e sua relação com o processo de desenvolvimento. Revista Brasil Florestal, v.2, n.54, p.13-28, abr./maio/jun. 1983.

REIGOTA, M. La transversalidad en Brasil: una banalización neoconservadora de una propuesta pedagógica radical. Tópicos de Educación Ambiental, v.2, n.6, p.19-26, 2000.

ROSA, A.V. Abordando as relações agricultura e meio ambiente no ensino formal, através da educação ambiental: considerações a partir de um caso. Piracicaba, 2001. 260p. Dissertação (M.S.) - Escola Superior de Agricultura "Luiz de Queiroz", Universidade de São Paulo.

ROSADO, F.J; AGUILLÓ, F.A. (Orgs.). Diagnóstico de los equipamientos de Educación Ambiental en Andalucia. Sevilla: Junta de Andalúcia, Consejería de Medio Ambiente, Consejería de Educación y Ciencia, Creaciones y impressiones Giralda, 1998. 72p. 
SÃO PAULO (Estado). Secretaria do Meio Ambiente. Coordenadoria de Educação Ambiental (CEAM). Programa núcleos de educação ambiental. São Paulo, 1998.

SATO, M. Debatendo os desafios da educação ambiental In: CONGRESSO DE EDUCAÇÃO AMBIENTAL PRÓ-MAR DE DENTRO, 1., Rio Grande, 2001. Anais. Rio Grande: FURG \& Pró Mar de Dentro, 2001. p.14-33.

SAVIANI, D. Escola e democracia: teorias da educação, curvatura da vara, onze teses sobre educação e política. São Paulo: Cortez / Autores Associados, 1987.

SEMINÁRIOS PERMANENTES DE EDUCACIÓN AMBIENTAL. Ministerio de Médio Ambiente, Secretaria General Técnica, Centro de Publicações , 1996.

SILVA, F.D. Os equipamentos de educação ambiental da Espanha inseridos na temática da agroecologia. Piracicaba, 2001. 63p. Monografia (Graduação) Escola Superior de Agricultura "Luiz de Queiroz", Universidade de São Paulo.

SIRKIS, A. Enquanto isso, na terra do pau-brasil... In: MCCORMICK, J. Rumo ao paraíso: a história do movimento ambientalista. Rio de Janeiro: Relume Dumará, 1992. p.215-224.

SORRENTINO, M. Educação Ambiental: avaliação de experiências recentes e suas perspectivas. In: PAGNOCCHESCHI, B. (Coord.). Educação Ambiental: experiências e perspectivas. Brasília, 1993. p.7-30. (Série documental. Relatos de pesquisa)

SORRENTINO, M. Crise ambiental e educação. In: QUINTAS, J.S. (Org.). Pensando e praticando a educação ambiental na gestão do Meio Ambiente. Brasília: IBAMA, 2000. p.93-104. 
SORRENTINO, M. De Tbilisi a Thessaloniki: a educação ambiental no Brasil. In: QUINTAS, J.S. (Org.). Pensando e praticando a educação ambiental na gestão do Meio Ambiente. Brasília: IBAMA, 2000. p.105-114.

SORRENTINO, M. Portas, chaves e restaurantes. In: SIMPÓSIO SUL BRASILEIRO DE EDUCAÇÃO AMBIENTAL, 1., Erechim, 2002. Anais. Erechim: EdiFAPES, 2002. p.91-99.

TRAJBER, R.; MANZOCHI, L.H. Avaliando a Educação Ambiental no Brasil: materiais impressos. São Paulo: Gaia, 1996. 226p.

TOMÉ. Apuntate la granja. 2000.

VEIGA, I.P.A. (Org.). Projeto político-pedagógico da escola: uma construção possível. Campinas: Papirus, 1999.

VEIGA, I.P.A.; FONSECA, M. As dimensões do projeto político-pedagógico: novos desafios para a escola. Campinas: Papirus, 2001.

VIOLA, E. O movimento ecológico no Brasil (1974-1986): do ambientalismo à ecopolítica. Revista Brasileira de Ciências Sociais, v.1, n.3, p.5-25, 1987.

VIOLA, E. O movimento ambientalista no Brasil (1971-1991): da denúncia e conscientização pública para a institucionalização e o desenvolvimento sustentável. In: GOLDENBERG, M. (Coord.). Ecologia, ciência e política. Rio de Janeiro: Revan, 1992. p.49-75.

WILSON, E.O. Biodiversidade. Rio de Janeiro: Ed Nova Fronteira, 1997. 